U. S. DEPARTMENT OF THE INTERIOR

U. S. GEOLOGICAL SURVEY

STRUCTURAL ANALYSIS AND ORE CONTROLS
IN THE
COEUR D' ALENE MINING DISTRICT, IDAHO

by

Rolland R. Reid 1

Terry J. Hayden 1

Craig S. Wavra ${ }^{2}$

William D. Bond ${ }^{2}$

Open-File Report 93-235

March 1993

This report is preliminary and has not been reviewed for conformity with U.S. Geological Survey editorial standards or with the North American Stratigraphic Code. Any use of trade, product, or firm names is for descriptive purposes only and does not imply endorsement by the U. S. Government.

1. University of Idaho Moscow, Idaho
2. Sunshine Precious Metals, Inc. Kellogg, Idaho 
Beltian rocks in the Coeur $d^{\prime}$ Alene district of Idaho, lying within the Lewis and Clark line, display a complex history of deformation and metamorphic fabrics. The earliest fabric is a near-bedding-parallel schistosity (assigned to D1). Upright folds of northerly trend lie north of the district; comparable folds partily uverturned trend WNW within the district, subparallel to the Osburn fault. The folds are assigned to D2a.

Metamorphic cleavage (assigned to D2b) trends generally WNW but cuts across the folds in various ways. It shows major differences in two principal areas. In a three-mile-wide zone subparallel to and immediately north of the Osburn fault, cleavage is axially symmetrical about an approximately $40^{\circ}-\mathrm{NW}-$ plunging stretching lineation. Outside that zone, the cleavage is dominantly planar, dips steeply to the SSW, and contains a strong dip-line stretching lineation.

Semi-brittle faults and veins (assigned respectively to D2c and D2d) cut the cleavage and are in part axially symmetrical about a steep, SSW-plunging axis, paralleled by ore-shoot axes and slickenlines. Veins are concentrated in several zones or mineral belts symmetrically arrayed across the three-mile-wide zone of cleavage. Post-ore normal faults are axially symmetrical about a near-vertical axis. Brittle faulting in and near the Osburn fault zone cuts all the other structures.

Early deformation (D1) began perhaps during the East Kootenay orogeny at about $1400 \mathrm{Ma}$. Near-bedding-parallel schistosity may have been generated during a regional flattening event.

Subsequent deformation D2 generated folds, cleavage, faults, and veins. During $\mathrm{D} 2 \mathrm{a}, \mathrm{N}-\mathrm{S}$ folds were rotated into WNW trends within the Lewis and Clark line. Sinistral slip is suggested. The age of $\mathrm{D} 2 \mathrm{a}$ is not clear; it may be later Precambrian, late Cretaceous, or the features may reflect fabrics developed in part during each of these times. Critical to this and the following interpretations is the age of the Coeur $d^{\text {. }}$ Alene ore deposits, either late Precambrian or late Cretaceous according to current controversy. Tectonic scenarios remain speculative at the current level of knowledge.

Cleavage of two types developed, assumed to be synchronous and assigned to $\mathrm{D} 2 \mathrm{~b}$. One type is ductile fault cleavage, formed in the herein-defined, three-mile-wide Terror fault zone (TEZ). Oblique ductile slip, perhaps sinistral, generated axially symmetric cleavage around a NW-plunging stretching lineation during apparent constriction flow along the TEZ. The planar cleavage, developed in the walls of the TEZ, occurs in an anastomosing transection fabric which cuts folds at various angles, has a stretching lineation along its dip, and developed during ductile reverse faulting.

Variably mineralized faults (D2c) and veins (D2d) cut and displace cleavage; those considered here lie outside the TEZ. These fractures intersect in the average slip line shown by slickenlines, have anastomosing patterns giving rise to axial symmetry, and are considered to have formed during apparent constriction fracture flow (fracture-controlled, distributed 
ductile flow in a uniaxial stress field). Mineralization was synchronous with movements during late-stage, greenschist-facies metamorphism. Simultaneous reverse and normal movements occurred along the fractures in different places, during inhomogeneous strain.

Mineral belts are symmetrically arrayed across the TEZ, which is therefore a proposed ore channel. Ore shoots are elongate in the slip line, defined by vein intersections and slickenlines, plunging steeply to the SSW. That plunge direction defines a principal exploration guide--up and/or down plunge. Post-vein normal faults, axially symmetric about a nearvertical axis, are common in the two mines (Bunker Hill and Sunshine) examined during this study, occur also along the western margin of the district, and perhaps district wide.

Uniaxial stress is indicated, perhaps generated in the roof rocks above a deep intrusion. Alternately, tectonic relaxation may be involved.

Laramide faulting (D3) occurred during dextral transcurrent movements. No significant fold or mineral belt rotation is seen; movements appear to be purely translational. 
Abstract $\quad 2$

List of figures

Introduction $\quad 8$

General 8

Structural geometry: description and interpretation 9

$\begin{array}{ll}\text { Areal geology } & 10\end{array}$

$\begin{array}{ll}\text { Previous work } & 11\end{array}$

Fold development $\quad 13$

Deformation D1 13

Development of D1 structures 14

Age of D1 structures $\quad 15$

Deformation D2a 15

Development of D2a structures 16

$\begin{array}{ll}\text { Cleavage development } & 17\end{array}$

Regional cleavage $\quad 17$

High strain zone $\quad 19$

Regional cleavage analysis $\quad 22$

Terror fault (high-strain) zone analysis $\quad 26$

Regional-TFZ cleavage correlation 31

Fracture development 33

Mineralized early faults (Class b) and veins

General 33

Sunshine mine data

District-wide data 36

Post-mineral faults 37

Early fault and mineralization history 38

Early faulting 38

Conditions of mineralization

Silver Belt phenomena 40

District-wide phenomena

General interpretations $\quad 45$

Post-ore normal faulting $\quad 47$

$\begin{array}{ll}\text { other faulting } & 47\end{array}$

$\begin{array}{ll}\text { Joints } & 48\end{array}$

Guides to mineral exploration $\quad 49$

$\begin{array}{ll}\text { References cited } & 49\end{array}$ 
Appendix 1. Prichard (Kellogg) data set 56

Appendix 2. Lookout anticline data set 57

$\begin{array}{lll}\text { Appendix 3. Sunshine subarea bedding } & 58\end{array}$

Appendix 4. Sunshine vein attitudes from 57 veins 60

Appendix 5. Cleavage detail 61

Sunshine cleavage domain 1

Sunshine cleavage domain 2

Ross Gulch subarea detail $\quad 62$

Cleavage detail, Moon Creek and Terror Gulch subareas 64 
1. Status of mapping on the Coeur $d^{\prime}$ Alene project

2. Structural domains, Sunshine mine

$8 a$

3. PI diagram, bedding in Domain 3, Sunshine mine

$16 a$

$16 \mathrm{~b}$

4. BETA diagram, bedding in Domain 3 , Sunshine mine

$16 \mathrm{c}$

5. PI diagram, bedding in Domain 2, Sunshine mine

$16 \mathrm{~d}$

6. PI diagram, bedding in Domain 1, Sunshine mine

$16 e$

7. PI diagram, bedding in Domain 0 , Sunshine mine

$16 f$

$17 a$

8. PI diagram, cleavage in Domain 1 , Sunshine mine

$17 \mathrm{~b}$

10. PI diagram, cleavage in Domain 2 , Sunshine mine

$17 \mathrm{c}$

$17 \mathrm{~d}$

11. BETA diagram, cleavage in Domain 2, Sunshine mine

12. PI on cleavage set (a), Domain 3, Sunshine mine

13. PI on cleavage set (b), Domain 3, Sunshsine mine

$17 \mathrm{e}$

$17 \mathrm{f}$

14. PI on cleavage set (c), Domain 3, Sunshine mine

$17 g$

15. Average cleavages, Domain 3 , Sunshine mine

$17 \mathrm{~h}$

$18 \mathrm{a}$

16. PI diagram, bedding, Sunshine subarea

$18 \mathrm{~b}$

17. BETA diagram, bedding, Sunshine subarea

$18 \mathrm{c}$

18. PI diagram, cleavage, Sunshine subarea

$18 \mathrm{~d}$

19. BETA diagram, cleavage, Sunshine subarea

$19 a$

20. PI diagram, bedding, Lookout anticline subarea

$19 \mathrm{~b}$

21. BETA diagram, bedding, Lookout anticline subarea

$19 c$

22. PI diagram, cleavage, Lookout anticline subarea

$19 \mathrm{~d}$

23. BETA diagram, cleavage, Lookout anticline subarea

24. PI diagram, bedding, Prichard (Kellogg) area

25. BETA diagram, bedding, Prichard (Kellogg) area

26. PI diagram, cleavage, Prichard (Rellogg) area

27. BETA diagram, cleavage, Prichard (Kellogg) area

28. Bedding-cleavage intersections, Prichard area

29. Profile section, Ross Gulch subarea

$20 \mathrm{a}$

$20 \mathrm{~b}$

$20 \mathrm{c}$

$20 \mathrm{~d}$

$20 \mathrm{e}$

$21 \mathrm{a}$

$22 a$

31. BETA diagram, bedding, Tiger subarea $22 \mathrm{~b}$

32. PI diagram, cleavage, Tiger subarea 22c

33. BETA diagram, cleavage, Tiger subarea 22d

34. PI diagram, bedding, Burke subarea $22 \mathrm{e}$

35. BETA diagram, bedding, Burke subarea $22 f$

36. PI diagram, cleavage, Burke subarea $22 \mathrm{~g}$

37. BETA diagram, cleavage, Burke subarea $22 \mathrm{~h}$

38. PI diagram, Domain 1 veins, Sunshine mine 35a

39. 57 veins, beta diagram, for a set of 217 . 35b

40. Simple vein array, $\mathrm{NW}$ set $35 \mathrm{c}$

41. Simple vein array, $\mathrm{NE}$ set 35d

42. Vein array of intermediate complexity. $35 \mathrm{e}$

43. Complex vein array $35 f$

44. Anastomosing faults, Coeur d' Alene district $36 \mathrm{a}$

45. Anastomosing fractures $36 \mathrm{~b}$

46. PI, veins, Lookout anticline subarea 36c

47. BETA, veins, Lookout anticline subarea 36d

43. Set 1 mineral belt vein sets 37 a

49. Set 2 mineral belt vein sets $37 \mathrm{~b}$

50. PI diagram, faults in Domain 1, Sunshine mine $37 \mathrm{c}$

51. BETA diagram, faults in Domain 1, Sunshine mine $37 \mathrm{~d}$

52 PI, fault set (a), Domain 1. Sunshine mine $37 \mathrm{e}$ 
53. PI, faldt set (b), Domain 1, Sunshine mine $37 f$

54. PI, fault set (c), Domain 1, Sunshine mine $37 \mathrm{~g}$

55. Composite faults, Domain 1, Sunshine mine $37 \mathrm{~h}$

56. PI, faults in Domain 2, Sunshine mine $37 \mathrm{i}$

57. BETA, faulte in Domain 2, Sunshine mine $37 \mathrm{j}$

58. PI, faults in set (a), Domain 2, Sunshine mine 37k

59. PI, faluts in set (b), Domain 2, Sunshine mine 371

60. PI, faults in set (c), Domain 2, Sunshine mine $37 \mathrm{~m}$

61. PI, faults in set (d), Domain 2, Sunshine mine 37n

62. PI, faults in set (e), Domain 2, Sunshine mine 370

63. Average faults, Domain 2, Sunshine mine 37p

64. PI, faults in Domain 3, Sunshine mine 38a

65. BETA, faults in Domain 3, Sunshine mine $38 \mathrm{~b}$

66. PI diagram, joints, Sunshine subarea $49 a$

67. PI diagram, cleavage set (a), Domain 1, Sunshine mine $61 a$

68. PI diagram, bedding set (b), Domain 1, Sunshine mine $61 \mathrm{~b}$

69. PI diagram, cleavage set (c), Domain 1, Sunshine mine 61c

70. Composite cleavage from sets (a), (b), and (c), Domain 1 61d

71. PI on cleavage set (a) in Domain 2, Sunshine mine $62 a$

72. PI on cleavage set (b), Domain 2, Sunshine mine 62b

73. PI on cleavage set (c), Domain 2, Sunshine mine 62c

74. Three average cleavage planes, Domain 2, Sunshine mine $62 d$

75. Bedding-cleavage relations, Ross Gulch subarea $62 e$

76. Bedding-cleavage relations, Ross Gulch subarea $62 f$

77. Cleavages from the two previous figures $62 \mathrm{~g}$

78. Bedding-cleavage-rodding, Ross Gulch subarea $62 \mathrm{~h}$

79. Four bede, Ross Gulch subarea $62 i$

80. Bedding-cleavage-hinge-rodding, Ross Gulch subarea $62 \mathrm{j}$

81. Bedding-cleavage-rodding-hinge, Ross Gulch subarea $62 \mathrm{k}$

82. Bedding-parallel cleavage, Ross Gulch subarea 63a

83. Calculated hinge, Ross Gulch subarea 63b

84. Early, sub-isoclinal fold, Ross Gulch subarea 63c

85. Seven bedding planes from previous figures 63d

86. Six cleavage planes from previous figures $63 e$

87. PI diagram, bedding, Ross Gulch subarea $63 f$

88. BETA diagram, bedding, Ross Gulch subarea 63g

89. PI diagram, cleavage, Ross Gulch subarea 63h

90. BETA diagram, cleavage, Ross Gulch subarea 631

91. L-diagram, Ross Gulch subarea 63j

92. L-diagram, Ross Gulch subarea 642

93. Composite diagram, Ross Gulch subarea 64b 


\section{INTRODUCTION}

\section{General}

In the early $1980^{\circ} \mathrm{s}$, mining officials in the Coeur d' Alene district (Eig. 1) expressed apprehension about the course of continuing exploration for deep ore bodies in the district which have no surface expression. Existing work (see, e.g., Hobbs and others, 1965) suggested a history of folding and faulting, with associated cleavage partly related to both processes. Faults (see, e.g., Fryklund, 1964) controlled vein development in an array of mineral belts (Eig. 1).

In a meeting of intereeted persone from industry and from state and federal agencies, it was decided that structural analysis provided a possible avenue for development of further exploration ideas. Accordingly, a program of research combining underground, surface, and remote sensing structural data was devised; funding was obtained through the U.S. Geological Survey. In the course of the work, an area of two $1^{\circ}$ quadrangles was mapped at $1: 24,000$ and studied by seven advanced-degree students in geology at the University of Idaho (Fig. 1). Much of the mapping was for detail on minor structural features including folds and fractures, inasmuch as excellent geologic maps of the larger part of the area already existed (Hobbs and others, 1965), due to the U.S. Geological Survey. Our work demonstrates the independent development of (a) folding, (b) ductile transection cleavage formed during reverse faulting, (c) early, semi-ductile faults, and (d) semi-ductile, fracture-controlled veins developed in localized mineral belts during apparent constriction fracture flow and later normal faulting movements. Mineral belts, as Fryklund (1964) suggested, remain the best places to explore for blind ore bodies. Further, we show in general that down-plunge of the vein intersections and parallel ore shoots is the best exploration direction. Remotesensing data proved of little help in our work.

This report utilizes computer-based structural geometry, utilizing data sets from thesis projects plus two class projects, and from published maps, together with further work by the authors. The idea is that selected subareas should be representative of the larger area and thus provide reconnaissance information to characterize it.

Structural geometry procedures utilized shareware due to Peter Guth, University of Nevada (Micronet) and E.W. Decker, Old Dominion University (SNET). The format used in this report for orientation data follows current computer format: planes, e.g., N35W 30SW; lines, e.g., 30 N35W. Structural geometry is important in this work; some data sets are reproduced in the appendices in case others wish to analyze them.

Some petrography has been done, utilizing oriented specimens. Here, three orthogonal thin sections are prepared from each specimen, perpendicular to the three fabric axes. This procediure affords a three-dimensional view of fabric elements, and orientation data permit correlation of micro-structures to larger structural elements. 
Eigure 1. Coeur d' Alene project mapping, supported largely by the U.S. Geological Survey, covering eight $71 / 2$-minute quadrangle areas: (1) SW $1 / 4 \mathrm{Kellogg} 15^{\circ}$ quadrangle, mapped by Hayden (1991). (2) NW 1/4 Calder 15 quadrangle, mapped by Hayden (1991). (3) SE $1 / 4$ Kellogg $15^{\circ}$ quadrangle, mapped by Willoughby (1986). (4) NE 1/4 Calder $15^{\circ}$ quadrangle, mapped by Clough (1981), (5) SW 1/4 Burke 15 quadrangle, mapped by $J$. Ruis. Ruis left early, following an unscheduled budget cut, taking his mapping results with him; his work is therefore not reported here. (6) NW $1 / 4$ Wallace $15^{\circ}$ quadrangle, mapped by Vance (1981). (7) SE 1/4 Burke 15 $5^{\circ}$ quadrangle, mapped by Campo (1984). (8) $\mathrm{NE} 1 / 4$ Wallace $15^{\circ}$ quadrangle, mapped by Foster (1983). Clough and Vance mapped under D.O.I. grant G5184005. Hayden mapped partly under support from the Idaho Mining and Metallurgical Resources Research Institute. Geographic and geologic data from cited theses above and Hobbs and others (1965, Plates 1-5). Mineral belt locations are from Eryklund, 1965: 1. Page-Galena belt. 2. Sunset belt. 3. Carlisle-Hercules belt. 4. Tamarack-Marsh sub-belt. 5. Rex-Snowstorm belt. 6. GemGoldhunter belt. 7. Golconda-Lucky Friday belt. 


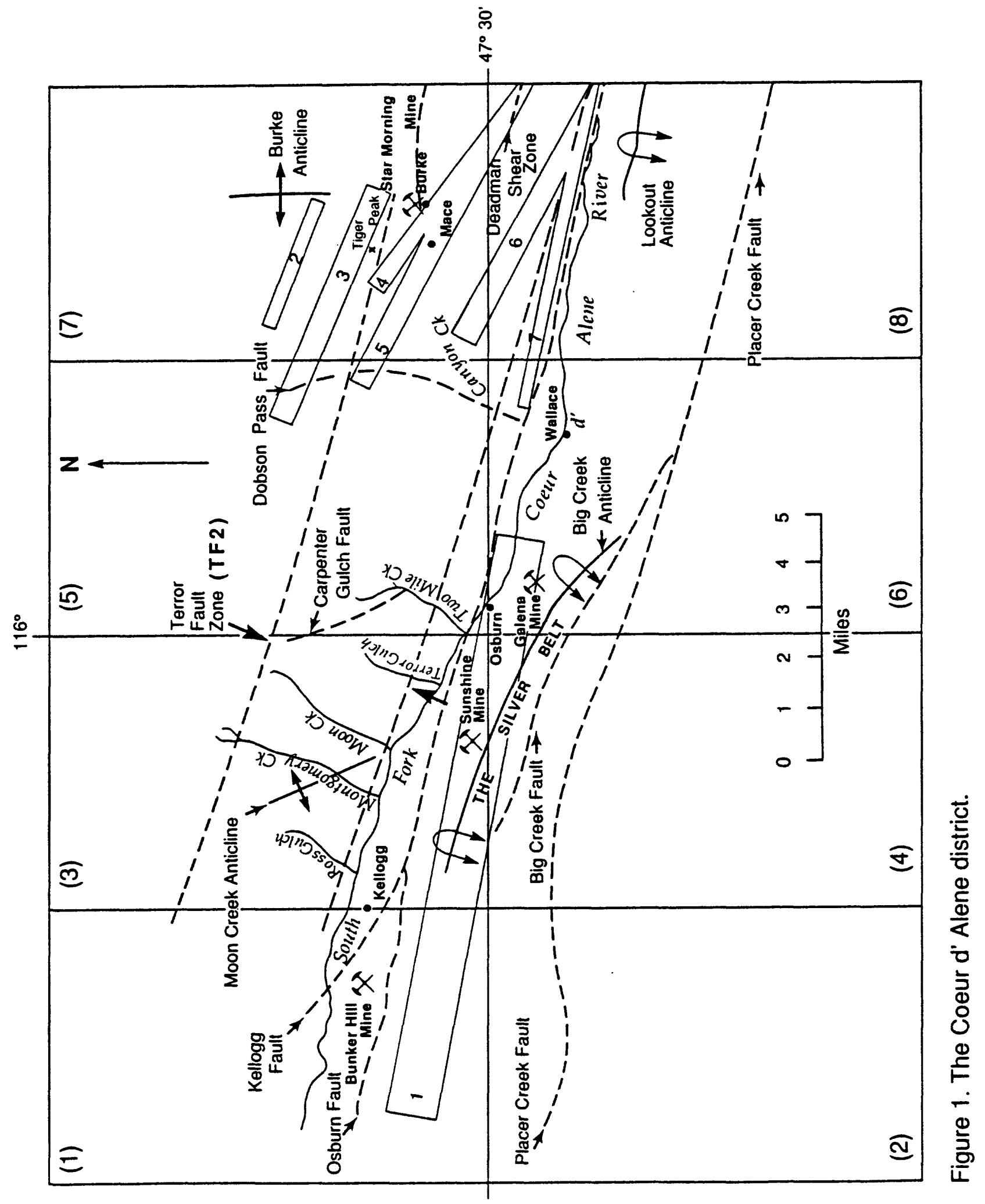


Structural Geometry: Description and Interpretation

Structural features possess symmetry elements related to the symmetry of the stress field(s) in which they formed. Computerbased analysis of large data sets provides rapid and viable estimates of symmetry elements. Both folds and fractures may be analyzed in this way.

Analysis is based on the use of PI diagrams, BETA diagrams, and/or $L$ diagrams. PI diagrams are generated by plotting in an equal-area stereonet poles to planar elements such as bedding, cleavage, faults, veins, and joints. BETA diagrams are generated by plotting all the lines of intersection of planar elements in a given data set; e.g., bedding attitudes. Folds may be cylindrical or conical; their PI diagrams are diffuse great or small circle girdles, respectively. Folds that are not strongly conical produce girdles that are not clearly either of great-or small-circle type; however, the girdle pole is an estimate of fold axis trend.

BETA diagrams for folds provide a clearer distinction between cylindrical and conical folds than do PI diagrams. It is noted that several workers have recommended against the use of BETA diagrams as being inaccurate (see, e.g., Ramsay, 1967). However, that was before the advent of modern computers. The central values from a large data set provide useful information about fabric symmetry, justifying the use of these diagrams. Cylindrical folds produce strong point maxima indicating axes in BETA diagrams, whereas conical folds produce large-circle girdles; those girdles provide an estimate of the axial-plane orientation, and a strong maximum within the girdle gives an estimate of fold axis orientation.

L diagrams show average linear trends, which may be related to any fold trends through comparison to PI and BETA diagrams.

Tectonic fracture sets may be generated in brittle or ductile environments exhibiting either plane- or biaxial-strain type. Cleavage of microschistosity type forms during ductile movements. It is commonly of axial planar character, fanning a bit in the folds. A PI diagram for such cleavage (generated during plane strain) will show a maximum perpendicular to the fold axial plane. A BETA diagram in this case will yield a point maximum providing an estimate of the fold axis. In case the fold-related cleavage is generated during biaxial strain, strain intensity and slip line orientation become important. For slip dominantly perpendicular to the fold axis, the PI maximum will be rather diffuse; in BETA, a great-circle girdle will emerge, defining the axial plane. A strong maximum in the girdle will provide an estimate of the fold axis, and one or more sub-maxima will lie on the girdle. For a single slip dominantly parallel to the fold axis, the cleavage will tend to form with axial

symmetry. Thus, PI will show a strong girdle perpendicular to the fold axis. Of course, this pattern can also be developed where an earlier cleavage is folded coaxially about the early fold axis. The choice of interpretation here depends on field data. 
Cleavage as defined above can also be generated during ductile faulting and will generally form along both of the conjugate shear directions, although one or the other of them is likely to be dominant. In case of plane strain, PI will show two sharp maxima in a partial girdle whose pole defines sigma 2 . BETA will yield a point maximum in sigma 2. In case of biaxial strain for such ductile faulting to produce cleavage, PI will show two diffuse maxima in a partial girdle whose pole defines sigma 2. BETA will yield a girdle defining the average sigma 3sigma 2 plane, and a principal maximum in the girdle defining sigma 2. The field aspect of the cleavage may be described as anastomosing.

Brittle faults generated in plane strain, if conjugate and extension fractures are included, will yield several point maxima in a partial girdle whose pole defines sigma 2 . BETA generates a point maximum in sigma 2 .

Brittle faults generated in biaxial strain, if conjugate and extension fractures are included, generate in a PI diagram diffuse maxima whose girdle pole is an estimate for sigma 2 . BETA generates a large-circle girdle defining the average sigma 1-sigma 2 plane, and the principal maximum in the girdle is an estimate for sigma 2 .

\section{AREAL GEOLOGY}

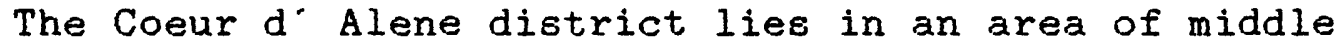
Proterozoic sedimentary rocks, part of the Belt Supergroup, principally argillite and quartzose siltite, in northern Idaho; and within the Lewis and Clark line, a major wrench fault zone of continental proportions and great antiquity which has experienced several periods of movement during its history. The term "Lewis and Clark line" is due to Billingsley and Locke, 1939. It is used in their format herein. although it denotes a fracture zone many miles wide. Within the Lewis and Clark line lies the Osburn fault (Fig. 1), known to extend from near Coeur d' Alene, Idaho, to near Missoula, Montana. To the west, across the Purcell trench, is Prebeltian gneiss of the Spokane dome, a part of the zone of metamorphic core complexes that parallels the western margin of the North American plate.

The Beltian rocks of the Coeur $d^{\prime}$ Alene district lie in the the greenschist facies; farther south, the rocks enter the amphibolite facies (Reid and Greenwood, 1968) nearer to the Idaho batholith. Metamorphism and accompanying deformation apparently occurred in two major pulses both of which pre-dated mineral deposition in the district. Many shallow-dipping, quartz-filled extension veins perhaps due to thrust movements cut district veins, although no large offsets have been documented. The latest geologic event of significance to topics herein was major dextral faulting along the Osburn fault, of Laramide age. 


\section{PREVIOUS WORK}

Only the earlier part of the work in the Coeur d'Alene district is examined here, to show how the geologic framework was established. The later part of the work is encompassed in an excellent summary by Constantopoulos (1989).

The earliest geologic comments of substance on the Coeur $d^{\text {- }}$ Alene mining district are those of Lindgren (1904), based on geologic field work done in the Bitterroot-Clearwater region from July 22 to October 22,1899 . At p. 108, he commented that "The deposits are clearly defined fissure veins cutting fine-grained greenish quartzites and quartzitic slates of doubtful (though probably pre-Cambrian) age." The deposits were valuable for lead and silver and estimated to have produced $\$ 60$ million since their discovery 15 years earlier. At p. 109, "In the exposures underground, as well as in the specimens and thin sections, the evidence of replacement is complete and positive." This bit of dogma established precedence for comparable statements in the literature at least into the middle $1960^{\circ} \mathrm{s}$. At $\mathrm{p}$. 111 , in an early recognition of mineral belts, Lindgren noted that "One system of vein (sic) strikes from Ninemile Creek across to Gem in an east-southeast direction, and thence across toward Mullan. Two parallel systems are found 2 and 4 miles north of Gem."

The next relevant publication is that of Ransome (1905), based on work during 1903-1904. This paragraph summarizes his contributions. At p. 277, he noted that no fossils have been found in the sediments of the Coeur $d^{-}$Alene Mountains and that they are therefore probably of Algonkian age. Pages 278-80 describe a thickness of about 15,000 ft of shallow-water deposits, cut by syenite stocks and a few dikes of diabase and lamprophyre. At p. 283, it is stated that the rocks are complexly folded and overturned, striking mostly northwest, but north trends occur, as near Mullan. Both normal and reverse faults occur, with throws up to 4,000 ft. At p. 284, the faults are said to parallel veins, and some of them pre-date the veins. At p. 285, it is speculated that the principal deformation occurred at the time of intrusion of the Idaho batholith. At $p$. 290, "The lead-silver deposits are in general metasomatic fissure veins, formed in greater part of replacement of siliceous sedimentary rocks along zones of fissuring." , and at p. 293, "They are generally tabular deposits, formed partly by the filling of open spaces, but largely by replacement along zones of fissuring or of combined fissuring and shearing." Such statements about vein filling and replacement invariably remind the senior author of his first trip underground at Butte, leading a class of students. Lecturing at the headframe and in response to a question, the mine geologist said that the vein we'd see underground was due about $80 \%$ to replacement and $20 \%$ to filling. Underground, sitting on a muck pile and looking at a solid, homogeneous, four-ft vein of chalcopyrite exposed in the back, the mine geologist, in response to a further question about the proportion of replacement to filling, said, "Well, I guess here it looks more like 50\% replacement and 50\% filling." This approach seems still to be widespread, 
The earliest detailed work in the Coeur d' Alene district is that of Ransome and Calkins (1908), establishing the stratigraphy and a broad understanding of the structure. They showed that the contiguous formations grade into one another and that all succeed one another conformably. The oldest formation is the Prichard (base not exposed), named from the Prichard Creek area, largely of argillite regularly banded in lighter and darker shades of blue gray. Next is the Burke, a siliceous unit largely of greenish-gray color, named from good exposures in the vicinity of the town of Burke. This is followed by the Revett, mainly of thick, white quartzite, named from Revett Lake, east of Granite Peak. Next above is the St. Regis, a unit of indurated, dark green or purple argillite and quartzite, named for good exposures about the headwaters of the St. Regis River. The next unit is the Wallace, thin-bedded, somewhat magnesian argillite, named for exposures in the vicinity of the town of Wallace. The highest unit is the Striped leak, after a mountain of that name situated between the heads of Big Creek and Placer Creek, of an appearance much like that of the St. Regis, although somewhat coarser grained. The generalized section given by Ransome and Calkins, 1908 , p. 25) comes to a thickness of 17,200 ft. Age of the formations was established by Walcott"s correlation from the Belt Mountains into Idaho. Detailed descriptions of the several units are given.

At p. 52, Ransome and Calkins established the relation of diabase dikes as injected both into the major and subsidiary faulte. At p. 60, they pointed out that the deformation cannot be placed more definitely than post-Algonkian and pre-Tertiary, but noted that inasmuch as the strike of beds, cleavage, and principal faults is approximately the same, all of these features have been subjected to the same forces. Folds are established as of a prevailing northwest trend, overturned in the vicinity of the Osburn fault (named at $p .62$ ). The major faults ( $p .62$ ) are established as both reverse and normal types. The Osburn fault, the one traced for the greatest distance, is established as a normal fault with a displacement in excess of $6,000 \mathrm{ft}$. Other major faults in the district, including the Placer Creek, Alhambra, Big Creek, White Ledge, $O^{\prime N e i l l ~ G u l c h, ~ D o b s o n ~ P a s s, ~ a n d ~}$ Carpenter Gulch, are named and described, although the Dobson Pass term was used earlier by Ransome (1905).

At $\mathrm{p}$. 65, cleavage is noted as widespread, yet best developed in the fine-grained, slaty rocks. At a given place, it is commonly about parallel to the principal fault planes. At $p$. 72 , it is suggested that the northeast row of syenite intrusions may mark the axis of an early, shallow anticline formed early and obscured by croes folds. At $p$. 73, dealing with the problem of the genesis of steep reverse faults, the possibility is noted that some such faults might contain some oblique or horizontal movement, followed by a further possibility (p. 74) that such faults are due to vertical forces rather than tangential ones. At P. 84, "The lead-silver ores come principally from metasomatic fissure veins. . . formed chiefly by the replacement of quartzite." At p. 106, over 99 percent of the Coeur d" Alene ore comes from the Revett and Burke Eormations. At p. 112, "In the Coeur $d^{\prime}$ Alene region . . ore is prevailingly massive. . 
And at p. 114,". . . deposits formed partly by filling . . but largely by replacement." Finally, at p. 125, ore shoots are elongate along the dip direction, steep to near vertical

Thus, by 1908, the major features of the Coeur d' Alene district had been established in very thorough work by the U.S. Geological Survey. Only the strike-slip character of the Osburn fault remained to be discerned, and that was first done by Hershey (1916). Shenon and McConnel(1940), interpreted flow (slaty) cleavage in the Big Creek anticline as essentially axial planar in nature. This was a re-interpretation of the idea from Ransome and Calkins, cited above, that the flow cleavage is about parallel to the principal faults (and by inference related to them).

\section{EOLD DEVELOPMENT}

Many workers (see, e.g., Hobbs and others, 1965, p. 2), have suggested that folds constitute the earliest element in the structural framework of the Coeur d' Alene district, formed prior to faulting and mineralization. In discussing the deformation history, the terms D1, D2 (subdivided into D2a, D2b, D2c, and D2d) and D3 will be convenient in the description and discussion of deformations and their various fold and fracture elements; it should be noted that the terms as used here do not correlate directly to similar terms used by other workers. E, $S$ and $L$ with numerical subscripts consistent with the $D$ sequence will characterize folds, cleavage or schistosity, and lineation.

\section{Deformation D1}

The earliest deformation structure in the Coeur d" Alene district is a weak "bedding-parallel" schistosity (S1), described by Hobbs and others (1965, p. 23-24); we attribute it to D1.

Although large recumbent isoclinal folds have not been recognized in the district, Willoughby (1986, p. 74-76) mapped a few small, recumbent isoclinal folds with WNW trends and shallowNE-dipping axial-plane schistosity in the Prichard Formation, in the southeast quarter of the Kellogg $15^{\circ}$ quadrangle (Fig. 1). In the essentially parallel limbs, schistosity apparently parallels bedding; cutting across it only in the fold hinges.

The small folds are attributed by us to D1; apparently, near-bedding-parallel slip generated few folds, but did form a widespread, early, near-bedding-parallel schistosity; described here as $\mathrm{S} 1$ relative to bedding taken as $\mathrm{s} 0$.

We processed 75 bedding attitudes from the northern part of the Willoughby thesis area (Fig. 1, 1986), in PI and BETA diagrams. The average fold trend is NOOW, and a strong BETA girdle with dip about $15^{\circ}$ to the north = average axial plane for conical isoclinal folds. Thus, at least locally, the isoclinal folds appear to dominate the fabric. Alternately, the "girdle" may just represent a local area of near-homoclinal aspect.

The question of the slip-line orientation during $D 1$ is of interest. A stretching mineral lineation should provide the best estimate. Up to now, no such lineation has been found on bedding

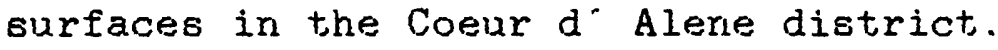




\section{Development of D1 Structures}

Reid (1984, p. 49) correlated the early schistosity to an axial-plane schistosity due to synchronous deformation and recrystallization in early recumbent isoclinal folds of the St. Joe region farther south (Reid and others, 1981, p. 172), which in that area appears to pass into a "bedding-parallel" schistosity to the north and east where the folds die out.

But note that what looks like bedding-parallel schistosity may cut bedding at small angles, not easily recognized in most exposures. As an example, early schistosity lying at an average of $2^{\circ}$ to the bedding in the Prichard Formation of northern Idaho (Bishop, 1973, p. 21) is invaded by synkinematic mafic sills. Given the Bishop observation and the caution from Ramsay and Huber, 1983, p. 181, that "Cleavage exactly parallel to bedding planes is very rare indeed, and close observation of many relationships termed bedding-plane cleavage reveal a small but detectable angle between the two planar structures."; it seems possible if not likely that the "bedding-parallel" schistosity of the Beltian rocks is really "near-bedding-parallel" schistosity. Use of the latter term is selected herein, for the above reasons. "Bedding-parallel" schistosity in Beltian rocks to the northeast has been discussed in the context of burial metamorphism (Maxwell and Hower, 1967; and Eslinger and Sellars, 1981); the referenced authors showed also that this early metamorphism was strongest, deep in the section and diminished upwards. Ramsay, 1967, $\mathrm{p}$. 471 , showed that layer-parallel slip generates no folds.

From the work by Hayden (1992) near the western margin of the Coeur d Alene district, open, conical folds lie south of the Osburn fault.

The near-bedding-parallel schistosity in the Belt rocks was no doubt generated when the beds were more or less horizontal. Given that correlative(?) isoclinal folds to the south show no major inversions (Reid and others, 1981, p. 199) in the sense of classical nappe structures, a flattening hypothesis may be considered. Literature for Proterozoic rocks in the northern U.S.A. mid-continent contains numerous descriptions of early flattening fabric. The early fabric in the Beltian rocks of northern Idaho may be interpreted as due to flattening as well (see, e.g., Reid and others, 1981, p. 153, with reference to orthogonal recumbent isoclinal folds).

Flattening might be due to loading from above. Tectonic stacking of nappes or thrust sheets over generally horizontal beds, followed by ductile readjustments during isostatic compensation, would involve near-bedding-parallel slip.

Concurrent metamorphic recrystallization would result in a nearbedding-parallel schistosity.

Flattening might also be due to uplift generated by thermal expansion in the upper mantle above a rising convection cell. Further, rocks of Idaho batholith type might be involved in the deformation. Ductile readjustments in broadly horizontal bedding resulting in near-bedding-parallel flow would produce nearbedding-parallel schistosity. Bishop (1973, p. 59) expressed comparable thoughts: "A diapiric uprise of mantle material would 
have caused a significant steepening of the geothermal gradient, thus supplying heat for metamorphism. Schistosity was developed by passive flow deformation of the clastic wedge."

The choice between the two mechanisms might be governed by the array of metamorphic zonation. The former scheme (stacking of nappes might provide an inversion of facies (for which there is no evidence in the region), whereas the latter (thermal expansion from below) would not. The latter scheme seems best for the Belt rocks, inasmuch as higher-T rocks occur deeper in the section. Of course deep burial would have the same effect, and this has been proposed by some workers as well. Varied slipline orientations might be expected, depending on the local directions of spreading flow.

Alternately, the near-bedding-parallel schietosity may suggest a recumbent style of gliding tectonics common at plate margins in younger tectonic regimes and is thus perhaps indicative of a convergent plate margin at D1 time. Here, subduction mechanics might be involved.

\section{Age of D1 Structures}

The age of the D1 event may correspond to the 1,300-1,400 Ma metamorphic event in the lower Beltian rocks of western Montana and northern Idaho (Obradovich and Peterman, 1968; Reid and Greenwood, 1968; Reid and others, 1973; Bishop, 1973; and Zartman and others, 1982) and in the Purcell strata of British Columbia (McMechan and Price, 1982, p. 476). Notably, Evans (1986) has documented evidence for felsic plutonism during this event, in a belt, extending from southeastern British Columbia through the Idaho panhandle and down into central Idaho; this is the Clearwater Orogenic Zone of Reid and others, 1973. In this correlation, it would belong to the East Kootenay orogeny (restricted) ' as redefined by McMechan and Price. We are aware of no evidence for faulting in the Lewis and Clark line during D1.

\section{Deformation D2a}

Deformation D2 is considered in four parts: D2a (folding), D2b (cleavage development), D2c (early mineralized fault development), and D2d (vein development). The reason for this grouping lies in the possibility that all four elements belong in come measure to a single tectonic episode. Cleavage, faulting, and vein development are considered in later sections, whereas folding is described here.

The major folds in the Coeur $d^{\prime}$ Alene district are upright to overturned folds developed through bending the beds and their near-bedding-parallel schistosity during $\mathrm{D} 2 \mathrm{a}$ (note that this is the deformation characterized as D1 in many reports on the district). These folds are part of a regional, northerlytrending anticlinorium described by Hobbs and others (1965, $p$. 112). The folds are deflected into WNW trends within the Coeur $d^{\prime}$ Alene district and beyond.

The zone of fold deflection extends south some 16 miles to the St. Joe fault, a structure more or less parallel to the 
Osburn trend; and folds resume their north-south trends only south of that fault.

The Sunshine mine area (Eig. 1) provides a small domain to characterize folding in a part of the Coeur $d$. Alene district. As shown in Eigure 2, from the north limb of the Big Creek anticline (Eig. 1) as well as from the Sunshine mine, the structure is faulted, with homoclinal blocks in some mine domains. Domain 3 (Figs. 3 and 4 ) contains the principal fold hinge, whereas Domains 1 and 2 contain homoclinal segments in the north limb. Note, however, that tight, near-isoclinal folds dominate the "homocline" of Domain 2. Figure 4 shows that the fold is conical within the mine area. The isoclinal limb segment in Domain 2 averages an axial plane oriented N80W 80SW (Eig. 5), overturned; and the segment in Domain 1 averages N8OW 70 SW, also overturned (Eig. 6). That in Domain 0 is near vertical, N87W 86SW (Eig. 7) but also overturned.

D2a folds north of the Osburn fault and north of a highstrain zone described below trend due north, whereas those south of the fault and within the zone of regional deflection trend more northwesterly and nearly parallel to the fault (see, e.g., Hobbs and others, 1965, p. 112-113; and Campo, 1984, p. 50-51). Willoughby (1986) mapped three fold sets in Prichard rocks north of the Osburn fault, an early one of northeast trend, an intermediate(?) one of northerly trend, and a younger one of northwesterly trend, with complex overprinting of one upon another.

\section{Development of D2a Structures}

The D2a folds lie in an anticlinorium which is deflected to the left late in D2a (as we see it) where it crosses the Lewis and Clark line. This deflection is the expected one for the ductile response of layered cover rocks above a sinistral wrench fault (Moody and Hill, 1956). Sinistral drag folds of ductile character near the Osburn fault were first seen by the senior author in 1971 and have been studied by several workers in the district (see, e.g., Mathewson, 1972; Foster, 1983, p. 67; and Campo, 1984, p. 46).

Reid and others (1981, p. 170 and p. 174-175) showed evidence for ductile sinistral slip in the St. Joe fault zone synchronous with second-event metamorphism here correlated to D2a of the Coeur d Alenes. D2 folds in the St. Joe area show evidence for stretching in the direction of the fold axes: mudcrack polygons are strongly elongated in that direction (Reid and others, $1981, \mathrm{p} .169$ ). Thus, ductile biaxial strain is indicated during fold deflection in the Lewis and Clark line, with stretching in $X$ (fold axes), and $Y$ (normal to fold axes in the axial plane), and shortening in $Z$. $X$ and $Y$ may be reversed; evidence to this point is lacking.

Other authors, principally Hobbs and others (1965) and Bennett and Venkatakrishnan (1982), proposed rotation of the

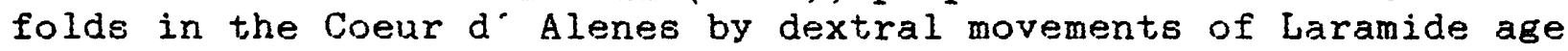
in the Lewis and Clark line.

These trend differences seem clearly due to differential rotation of folds toward an early fault zone during rotational 


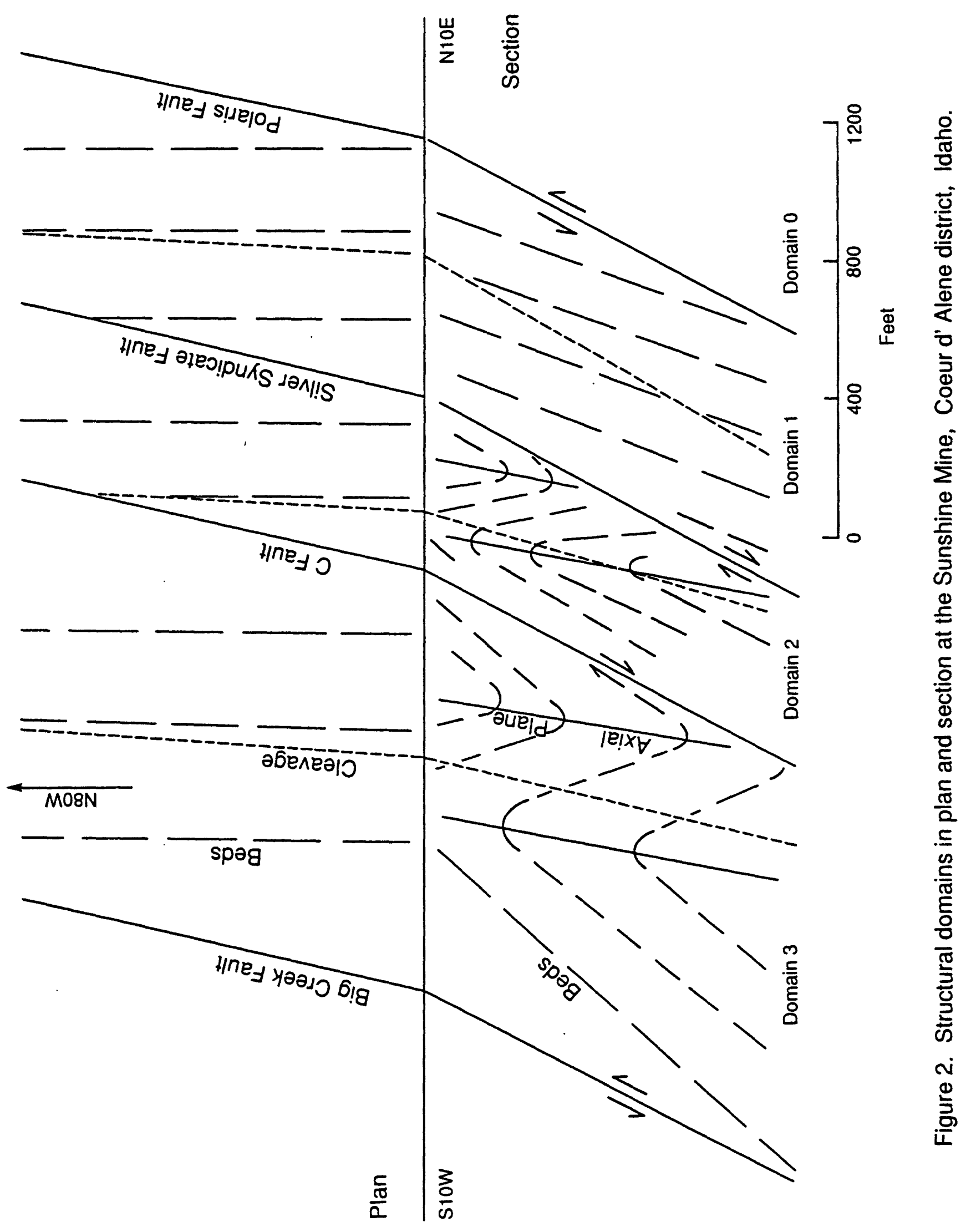




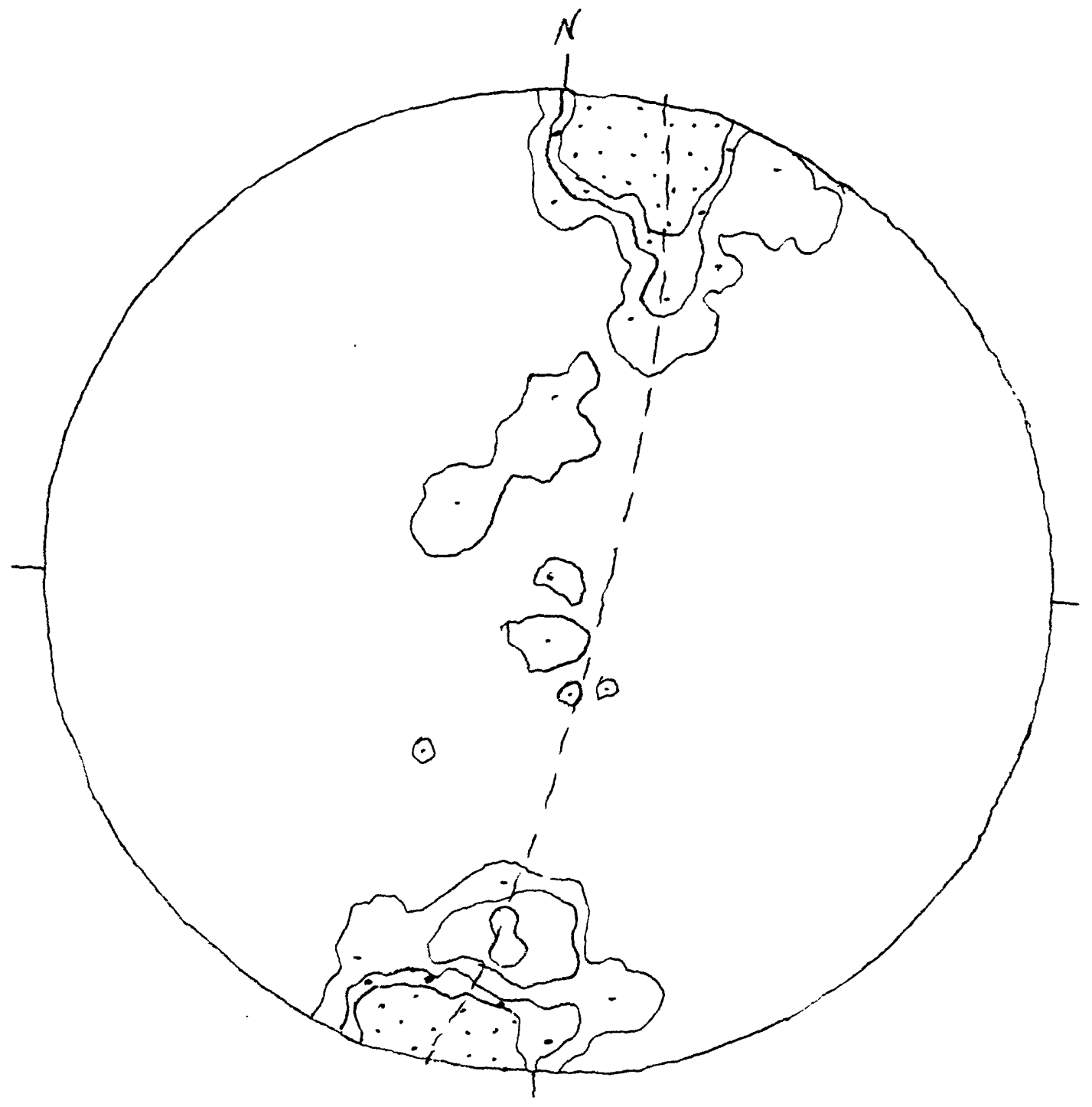

Eigure 3. PI diagram. Bedding in Domain 3, Sunshine mine, Coeur d' Alene district, Idaho. Partial girdle N12E 80SE, showing isoclinal folding about an axis in the girdle pole. $N=99$ planes chosen randomly from a set of 298 . Contours at $2,4,6 \%$ per $1 \%$ area. Schmidt net, lower hemisphere. 


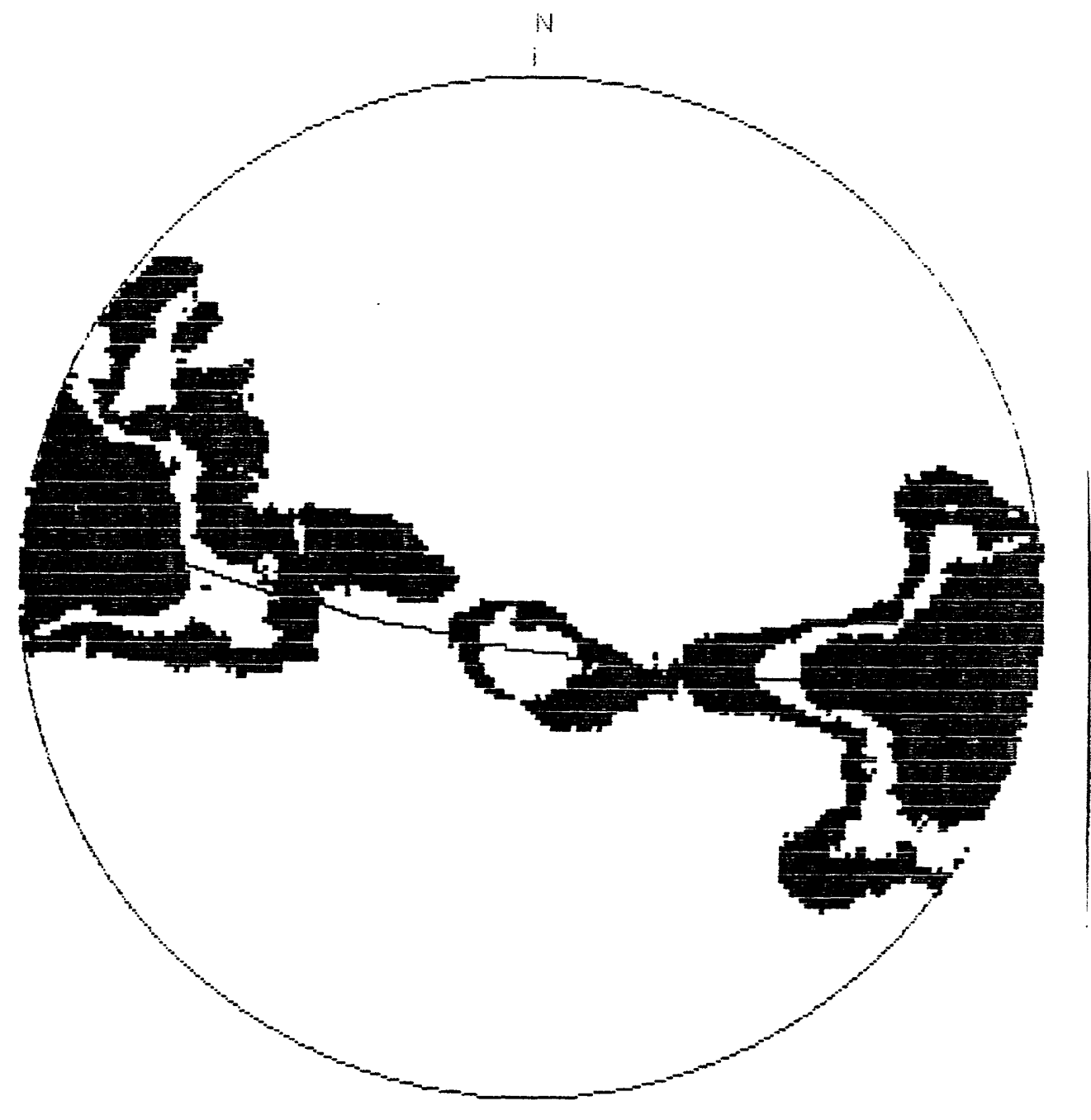

Eigure 4. BETA diagram. Bedding in Domain 3, Sunshine mine, Coeur $d^{-}$Alene district, Idaho. BETA maximum DO N80W. $N=4851$ points from intersections of 99 planes chosen randomly from a set of 298 planes. The point distribution shows a conical fold, and the girdle shows the axial plane, oriented NBOW 80SW. Contours at $2,4,6 \%$ per $1 \%$ area. Schmidt net, lower hemisphere. 


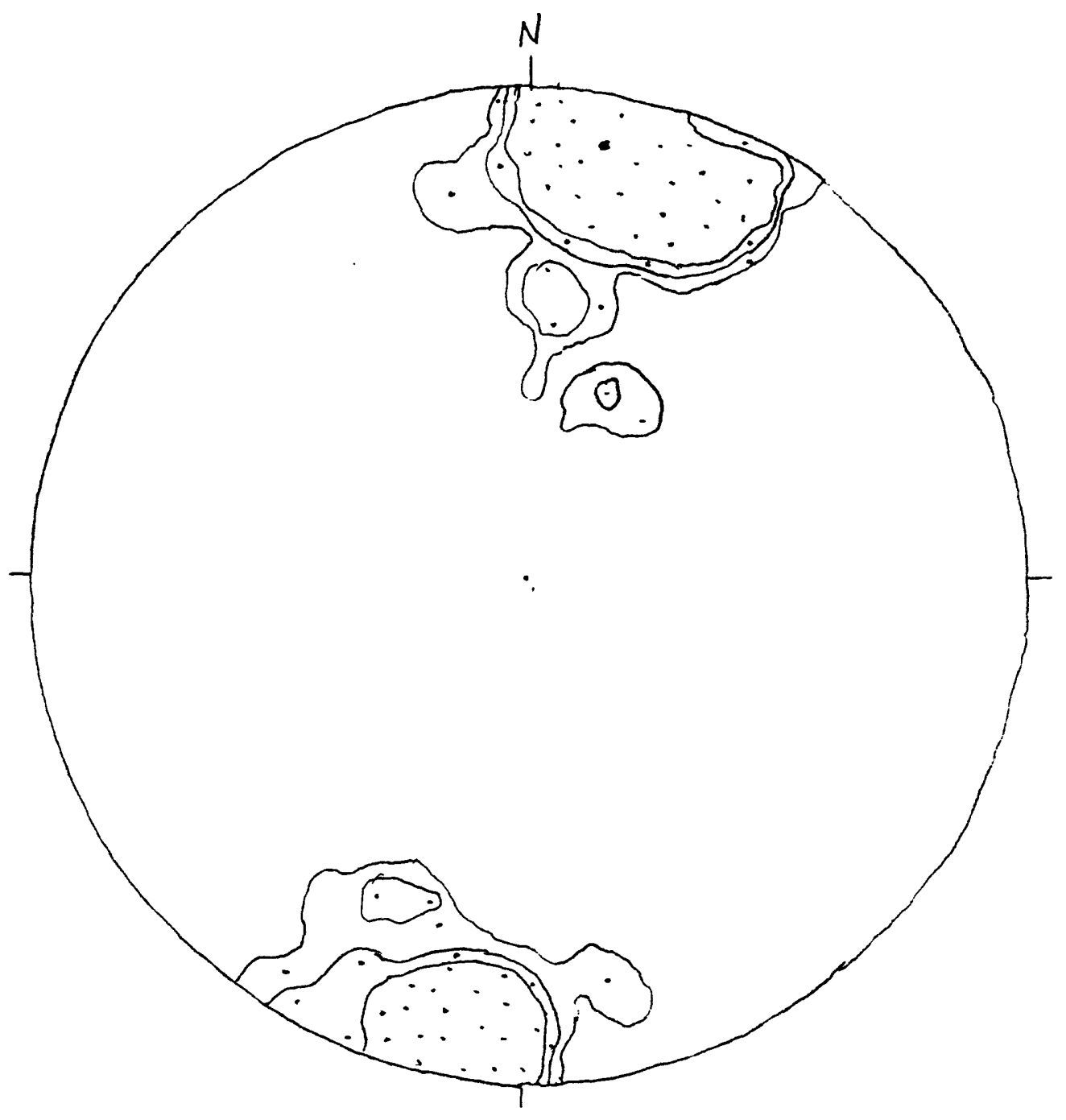

Eigure 5. PI diagram. Bedding in Domain 2, Sunshine mine, Coeur $d^{\prime}$ Alene district, Idaho. PI maximum $10 \mathrm{~N} 12 \mathrm{E}$. Steep fold limbs are emphasized. A BETA diagram not shown indicates an axial plane oriented N80W 63SW. $N=101$ planes chosen randomly from a set of 942 . Contours at $1,2,3 \%$ per $1 \%$ area. Schmidt net, lower hemisphere. 


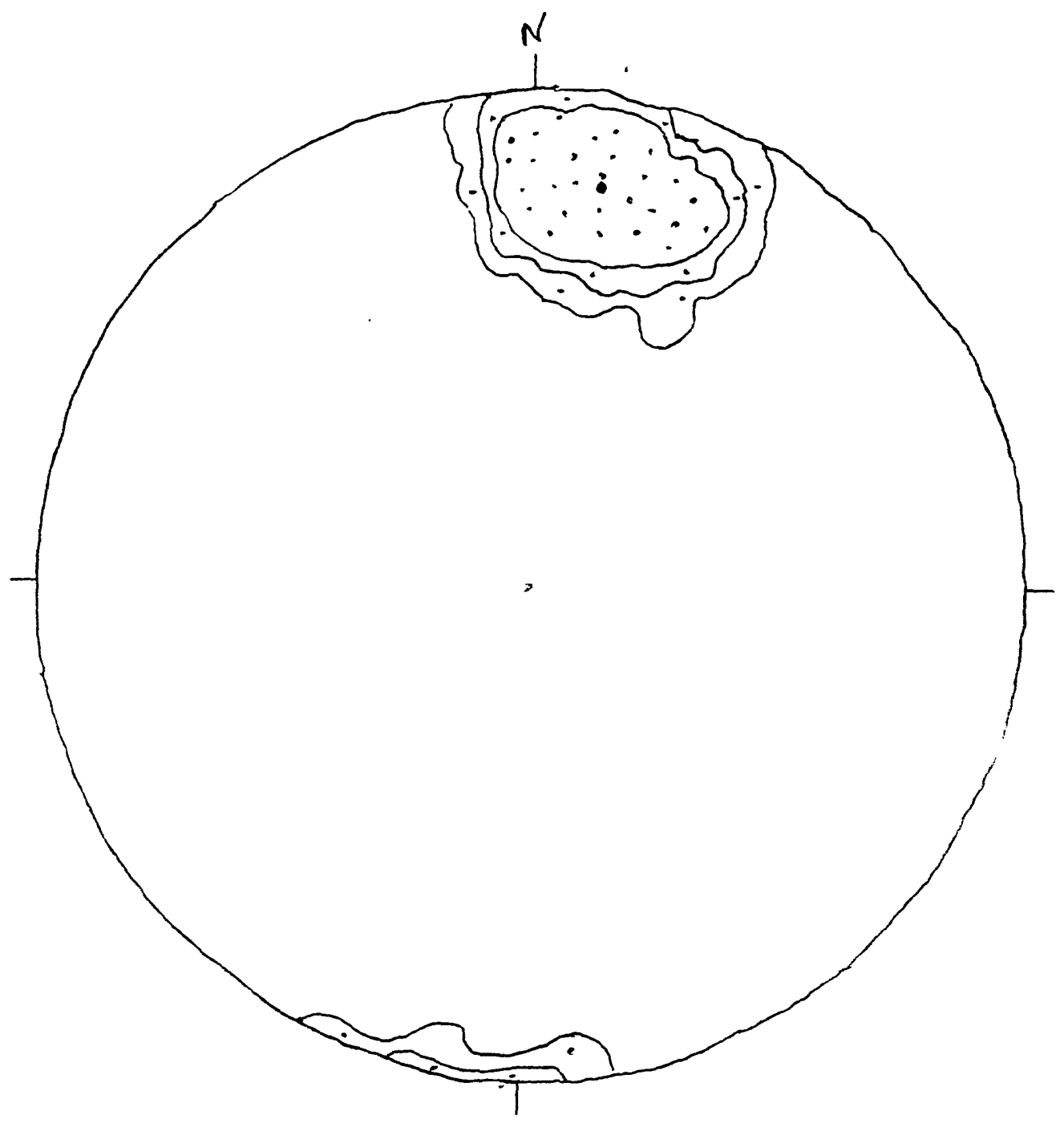

Eigure 6. PI diagram. Bedding in Domain 1, Sunshine mine, Coeur $d^{-}$Alene district, Idaho. PI maximum is $18 \mathrm{~N} 10 \mathrm{E}$, and the average bedding orientation is near N80W 70S. $N=97$ of 391 planes. Contours at $3,6,9 \%$ per $1 \%$ area. Schmidt net, lower hemisphere. 


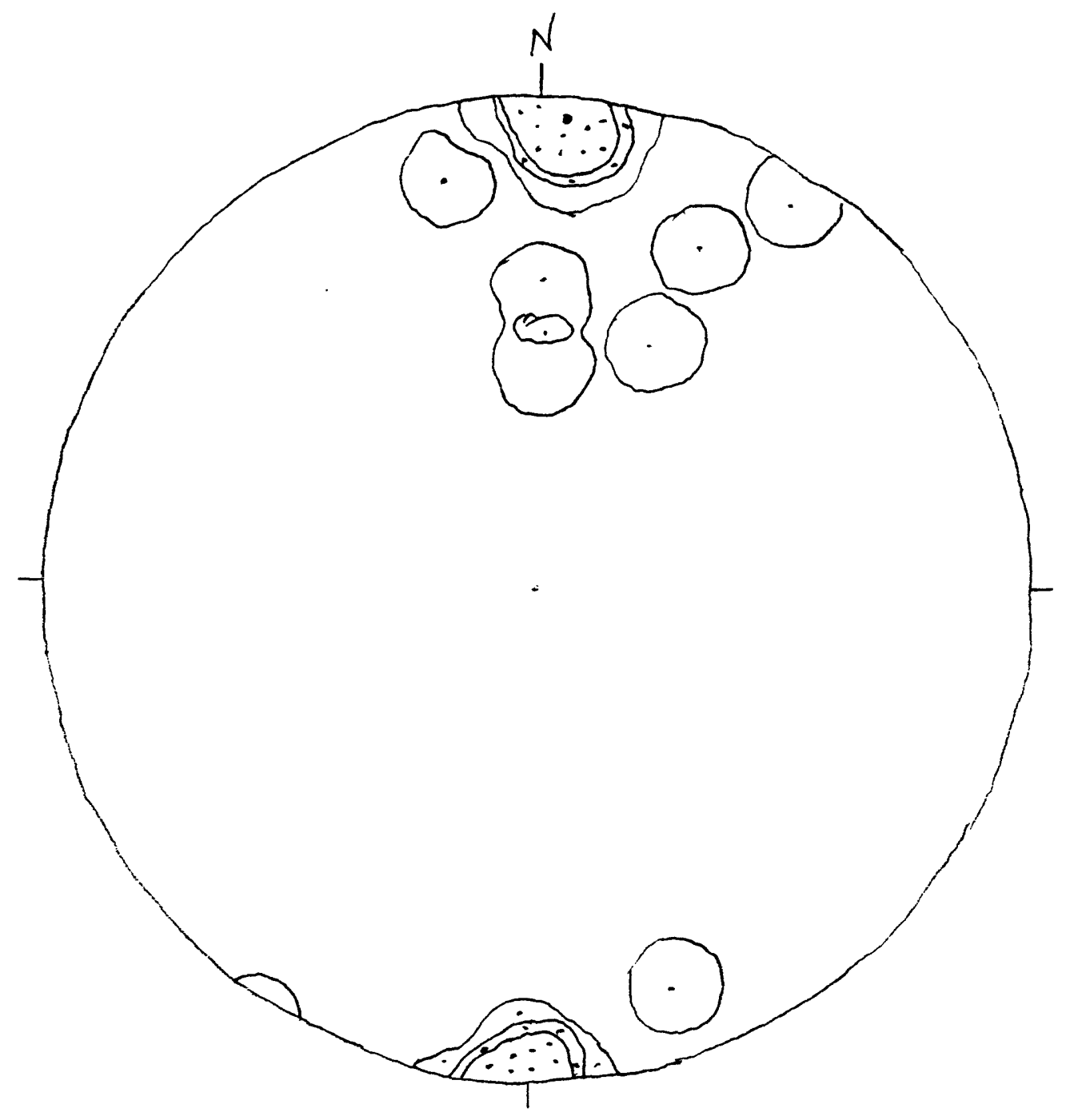

Eigure 7. PI diagram. Bedding in Domain 0, Sunshine mine, Coeur $d^{-}$Alene district, Idaho. PI maximum 04, N03E shows average bedding $N 87 \mathrm{~W}$ 86SW. $N=17$. Contours at $5,10,15 \%$ per $1 \%$ area. Schmidt net, lower hemisphere. 
strain, although White, 1989 , proposed a cross-folding mechanism.

The folds mapped by Willoughby, lying within a broad zone of ductile faulting defined in a subsequent section, developed perhaps during an early transform sequence of ductile faulting discussed later in this paper. Laramide transform movements in the Lewis and Clark line, connected with east-west crustal extension, have been proposed by Price, 1979; Rehrig and Reynolds, 1981; Seyfert, 1984; and Sheriff and others, 1984.

\section{CLEAVAGE DEVELOPMENT (D2B)}

Cleavage relations in the Coeur d' Alene district are more complex than suggested by earlier work. The term "cleavage" as we use it here is essentially synonymous with schistosity, as thin sections show cleavage to be expressed as a very finegrained schistosity. Herein, we will treat cleavage (all S2b and of a single age) in two parts: first, cleavage of regional type; and second, cleavage developed within a three-mile-wide zone of high strain, north of, partly abutting, and subparallel to the Osburn fault. Cleavage developments are markedly different in these two environments, particularly in the argillite of the Prichard Formation.

Because of the intricacies in cleavage relations, more general and somewhat summary comments are made in parts of this section on cleavage. Supplemental, detailed material is placed in Appendix 5.

\section{Regional Cleavage}

The Sunshine mine provides a small domain in which beddingcleavage relations can be examined in some detail. Cleavage in Domain 1 is characterized in Figures 8 and 9 . The average cleavage is oriented N78W $60 \mathrm{SW}$, but a few cleavage planes dip north. Bedding in Domain 1 (Fig. 6) is oriented N80W 725 , so the average cleavage dips $12^{\circ}$ shallower than the average bedding, whereas the average strikes are nearly parallel but average two degrees different. Further detail is in Appendix 5.

Cleavage in Domain 2 of the Sunshine mine is characterized in Figures 10 and 11 . The average cleavage is oriented N78W $75 \mathrm{SW}$, similar in trend but somewhat steeper than that in Domain 1. Bedding in Domain 2 is oriented N80W $80 \mathrm{SW}$ (Fig. 5), so the average cleavage dips $05^{\circ}$ shallower than the average bedding, whereas the average strikes are nearly parallel. Cleavage features in Domain 2 are similar to those of Domain 1; detail on this domain is provided in Appendix 5. The cleavage is generally independent of bedding (showing considerable strike variation), and cleavage intersection lines lie near the dip line.

Cleavage in Domain 3 is characterized in Figures 12,13 , and 14 for three trend-based sets: (a), (b), and (c). The average trends are compiled in Figure 15. The cleavage shows no particular relation to bedding. Again, intersections of the cleavage (of varied strike) lie near the dip line.

Evaluated next are bedding and cleavage data from the Clough thesis project (Fig. 1, quadrangle 4, designated as the Sunshine subarea), composited by us for the whole 7.5 -minute quadrangle. 


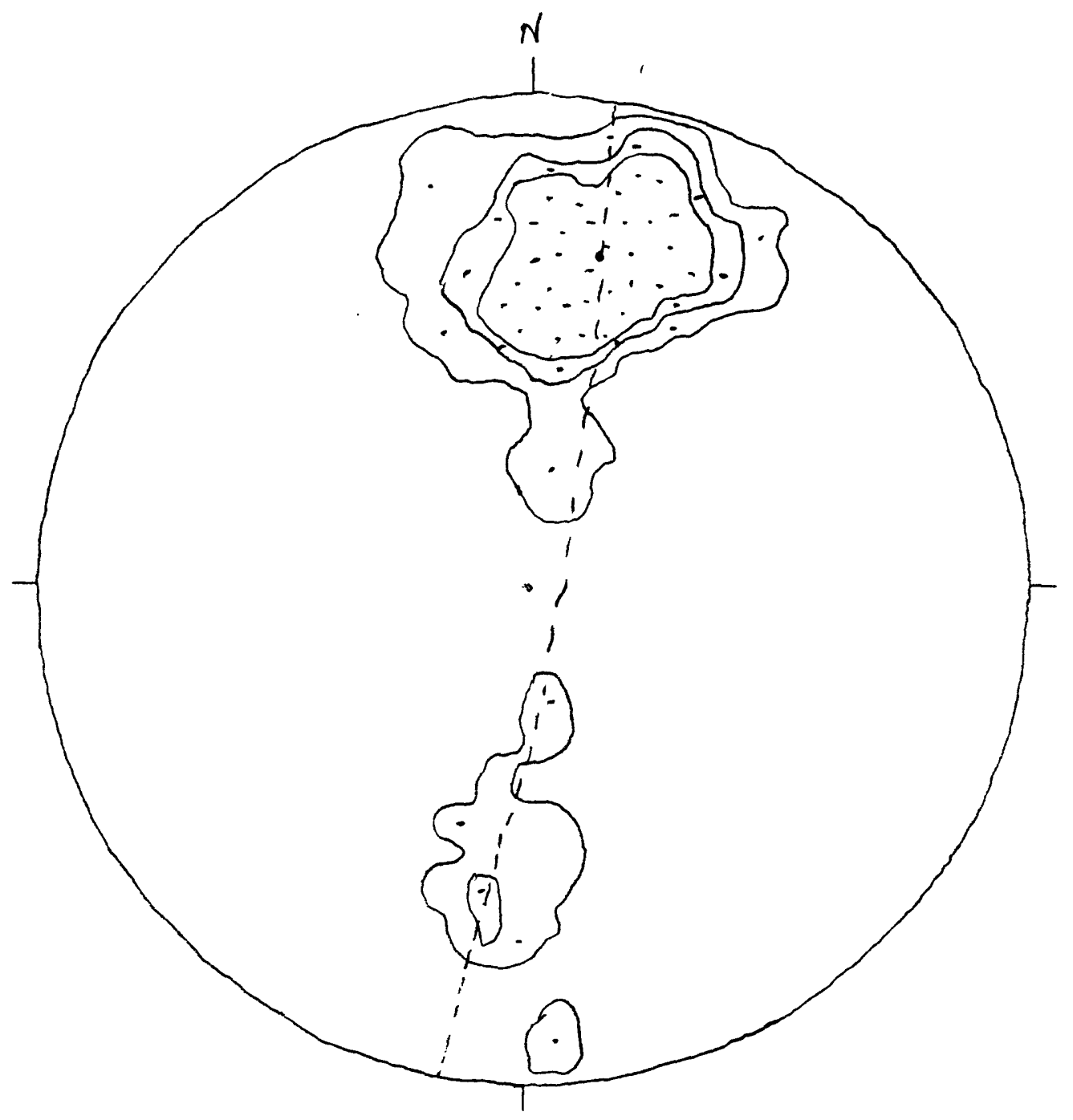

Eigure 8. PI diagram. Cleavage in Domain 1, Sunshine mine, Coeur $d^{\prime}$ Alene district, Idaho. PI maximum 30 N12E. Partial girdle N1OE 85SE. Compare with bedding in Domain 1 (Eigs. 2 and 6 ). $N$ $=87$, chosen randomly from a set of 268 measurements. Contours at $2,4,6 \%$ per $1 \%$ area. Schmidt net, lower hemisphere. 


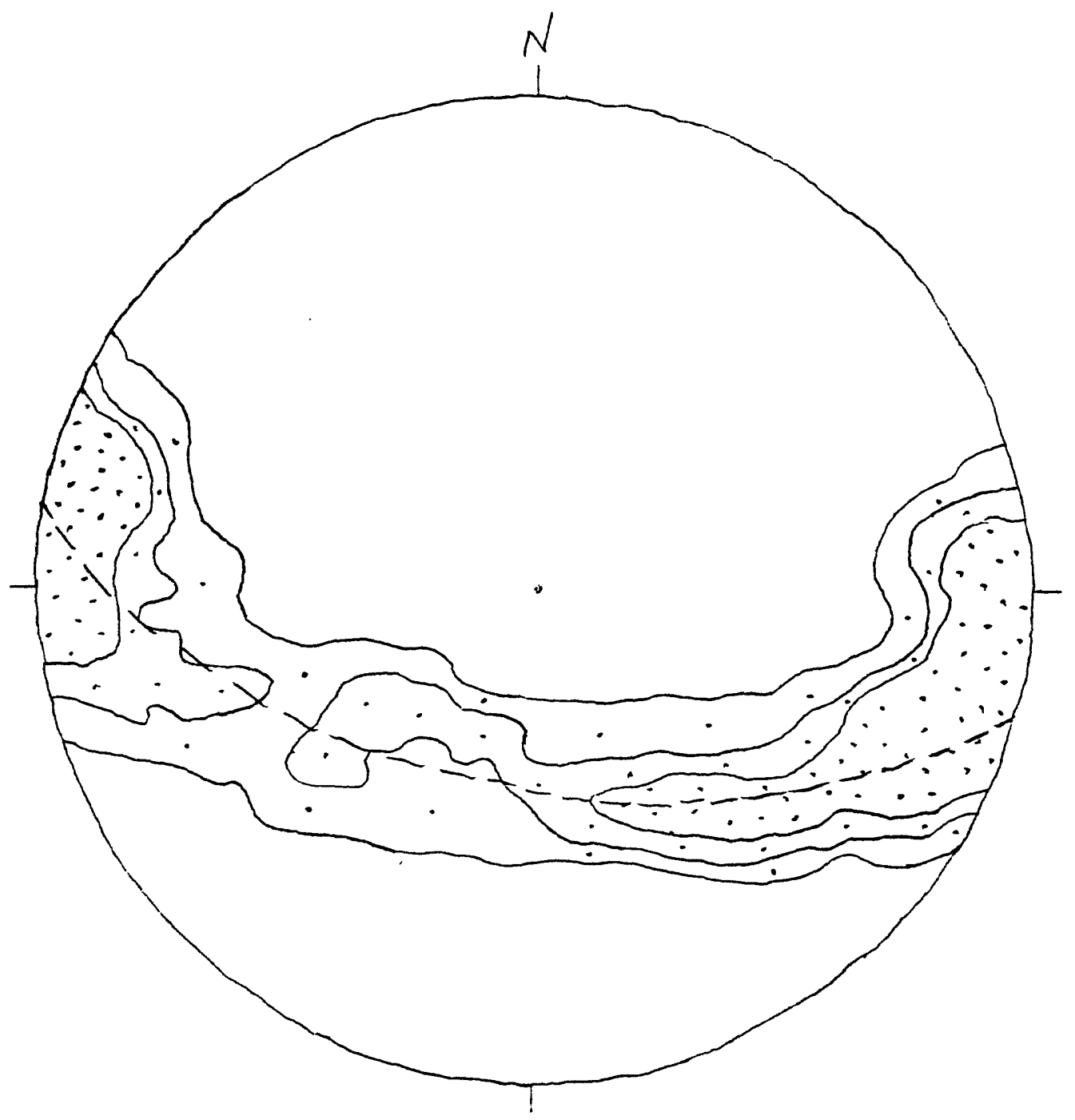

Eigure 9. BETA diagram. Cleavage in Domain 1, Sunshine mine, Coeur $d^{-}$Alene district, Idaho. Girdle approximately N78W 60SW shows average cleavage oriented $\mathrm{N} 78 \mathrm{~W} 60 \mathrm{SW} . \quad \mathrm{N}=3741$ points from intersections of 87 planes chosen randomly from a set of 268 measurements. Contours at $1,2,3 \%$ per $1 \%$ area. Schmidt net, lower hemisphere. 


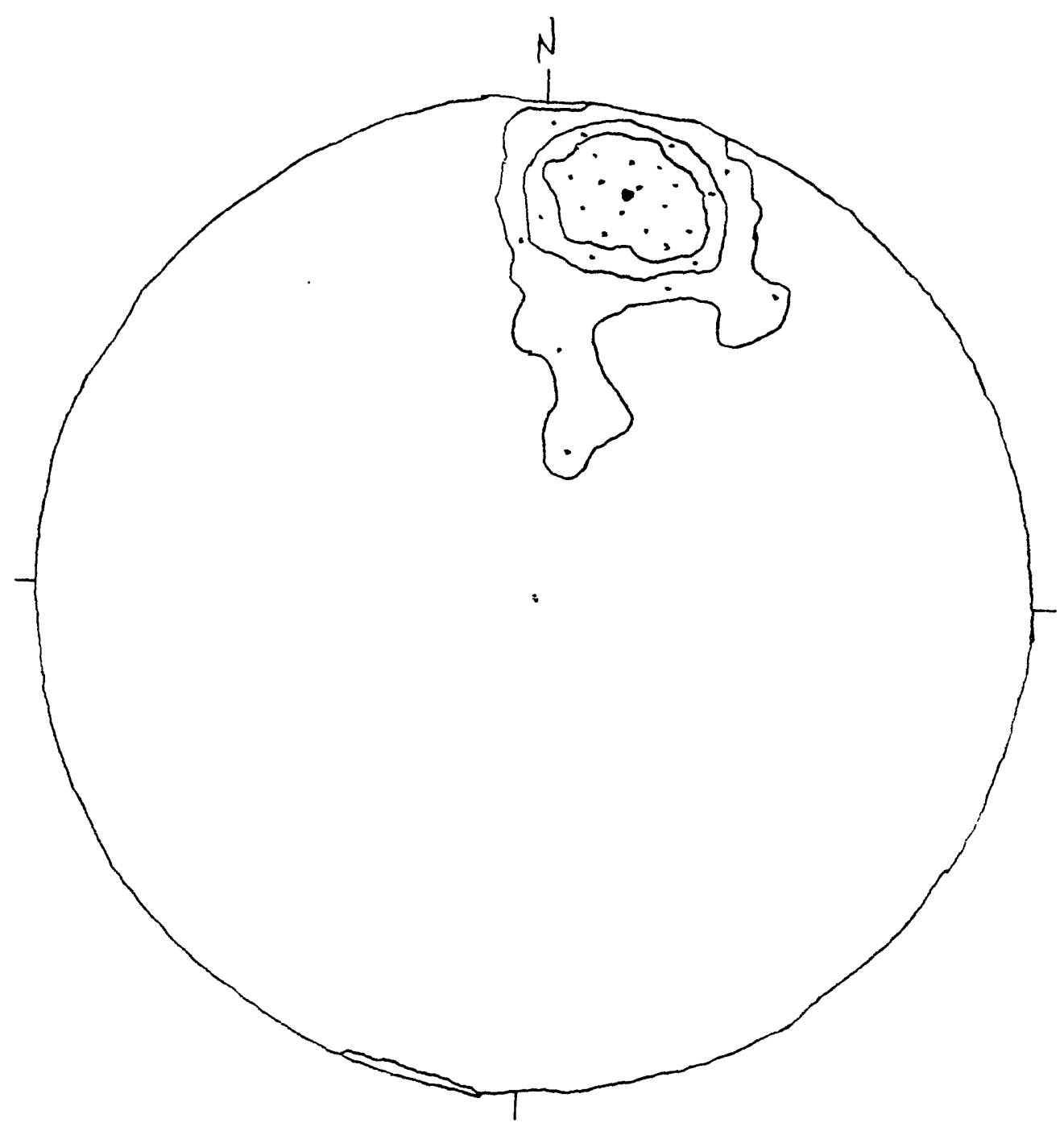

Figure 10. PI diagram. Cleavage in Domain 2, Sunshine mine, Coeur d' Alene district, Idaho. PI maximum 15 N12E. Compare to bedding in Domain 2 (Eigs. 2 and 5 ). $N=99$ planes chosen randomly from a set of 268. Contours at $4,8,12 \%$ per $1 \%$ area. Schmidt net, lower hemisphere. 


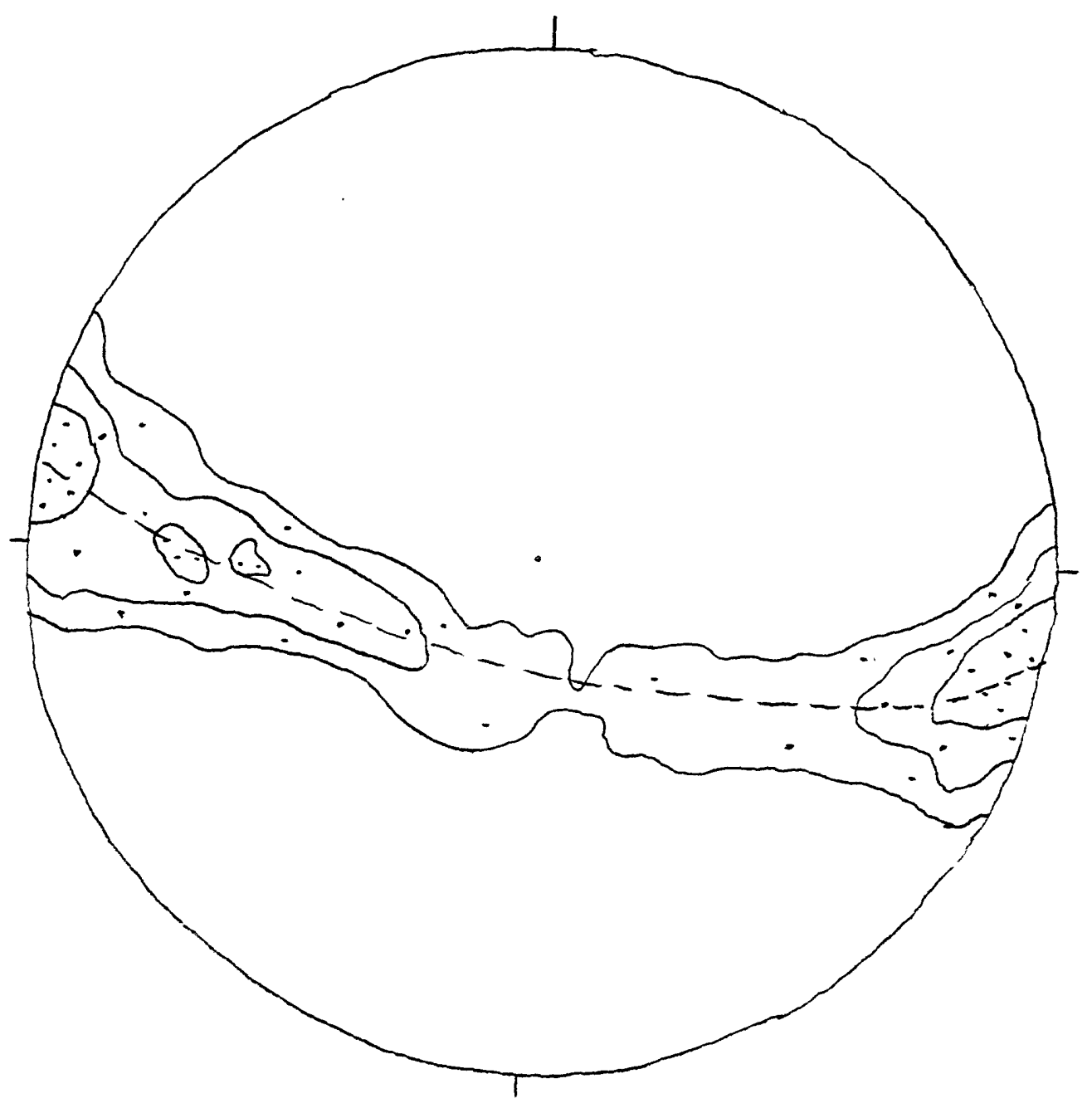

Figure 11. BETA diagram. Cleavage in Domain 2, Sunshine mine, Coeur d' Alene district, Idaho. Girdle N78W 75 SW shows average cleavage. $N=4851$ points from intersection of 99 planes chosen randomly from a set of 268. Contours at $2,4,6 \%$ per $1 \%$ area. Schmidt net, lower hemisphere. 


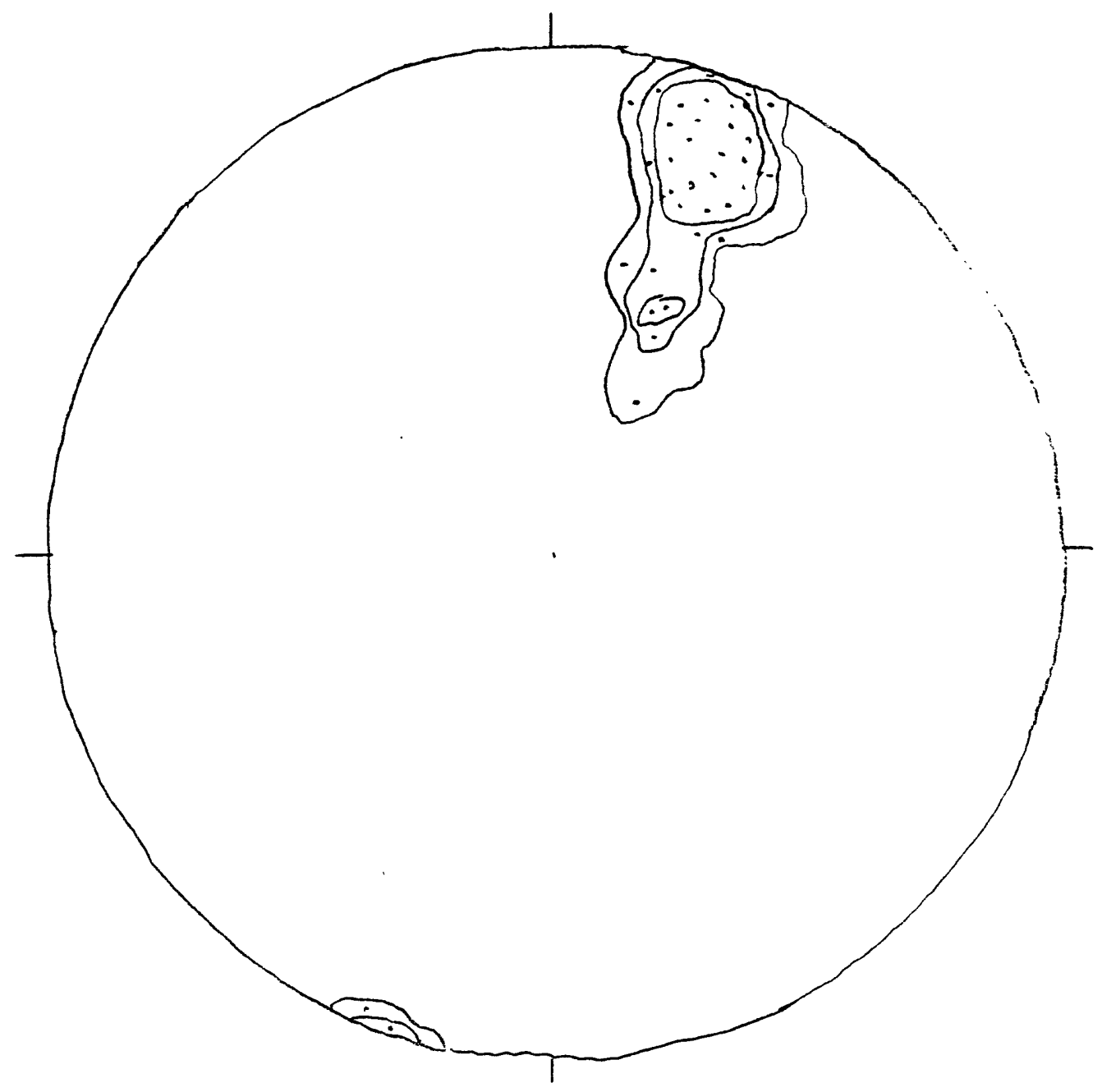

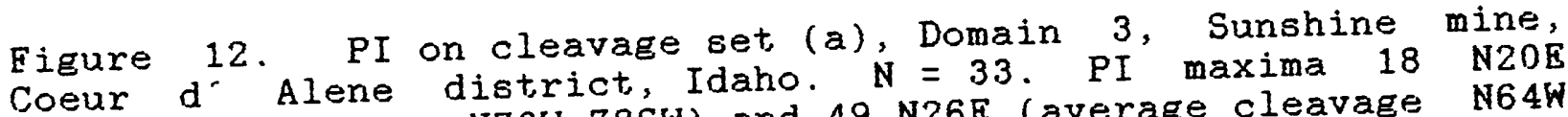
Coeur d Alene district, Idaho. 49 N26E (average cleavage N64W (average cleavage N70W $78 \mathrm{SW}$ ) and 49 conto $1 \%$ area. Schmidt net, lower hemisphere. 


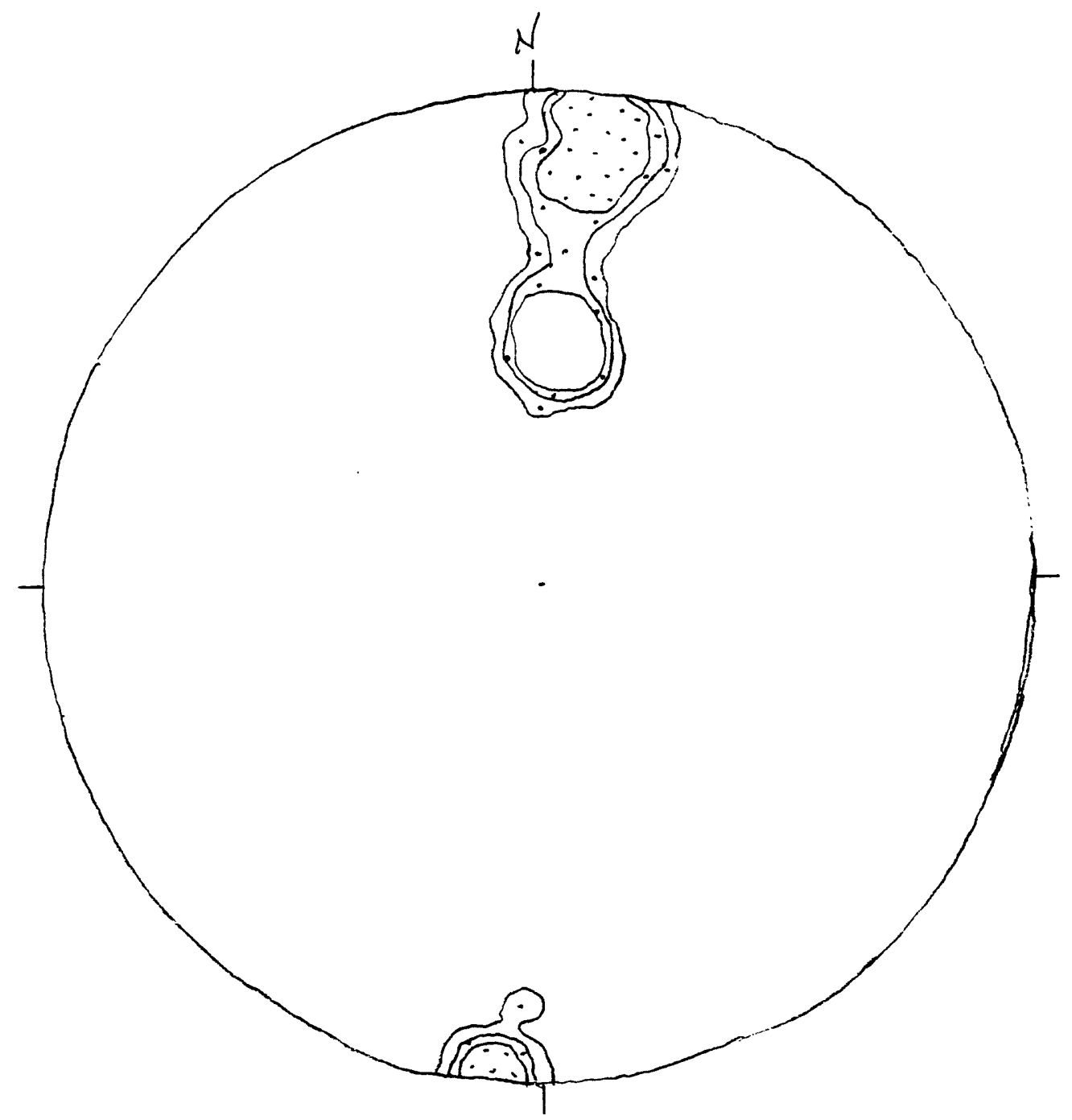

Eigure 13. PI on cleavage set (b), Domain 3 , sunshine mine, Coeur d' Alene district, Idaho. 49 NO3E (average cleavage = (average cleavage $=N 83 W 78$. Schmidt net, N87W 41SW). Conto 


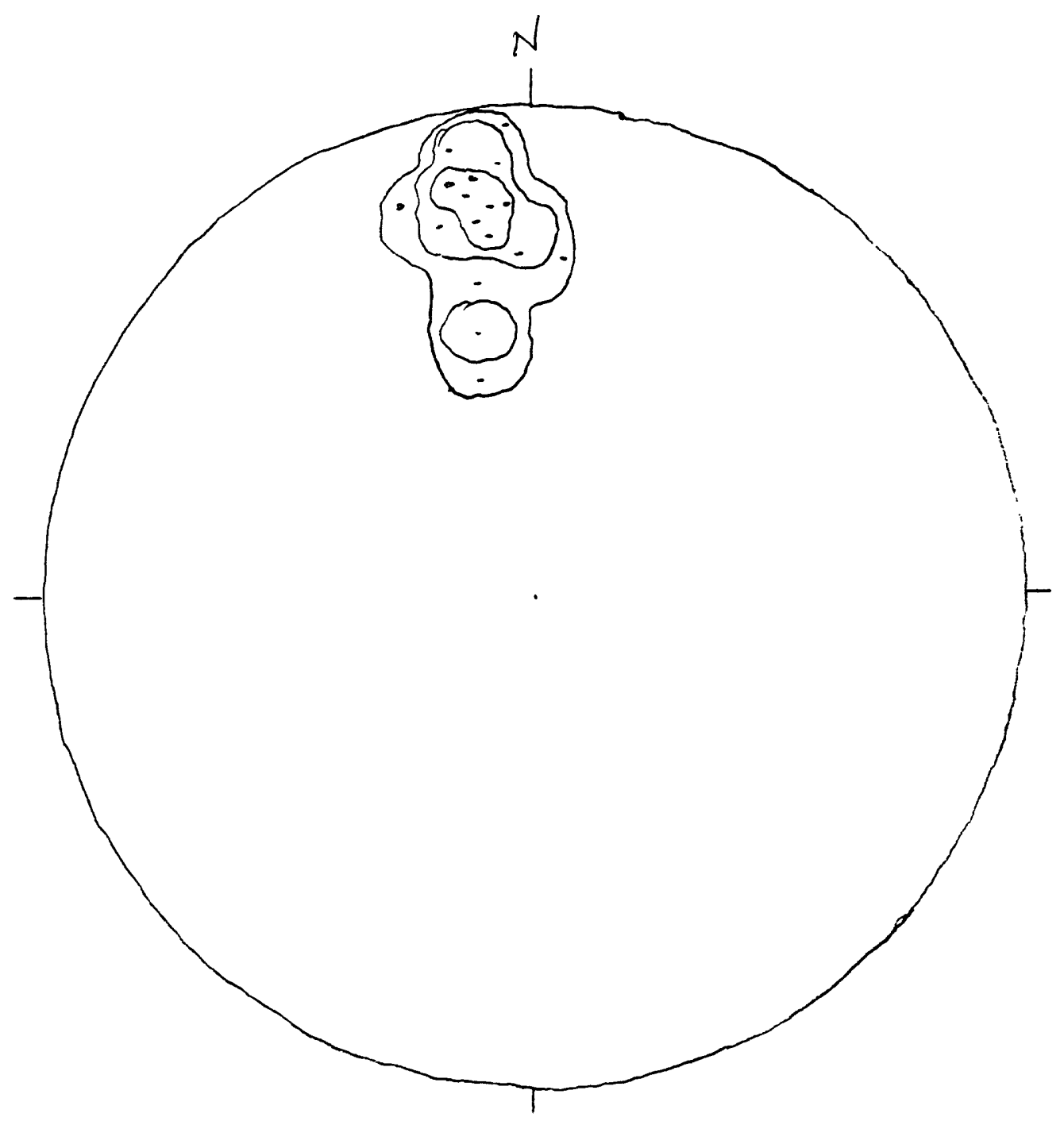

Eigure 14. PI diagram on cleavage set (c), Domain 3, Sunshine mine, Coeur d' Alene district, Idaho. $N=8$. PI maxima 21 N09W mine, Coeur d' Alene district,
(average cleavage $N 81 E 69 \mathrm{SE}$ ) and $43 \mathrm{~N} 12 \mathrm{~W}$ (average cleavage $=\mathrm{N} 78 \mathrm{E}$
$47 \mathrm{SE}$ ). Contours at $9,18,27 \%$ per $1 \%$ area. Schmidt net, lower

hemisphere. 


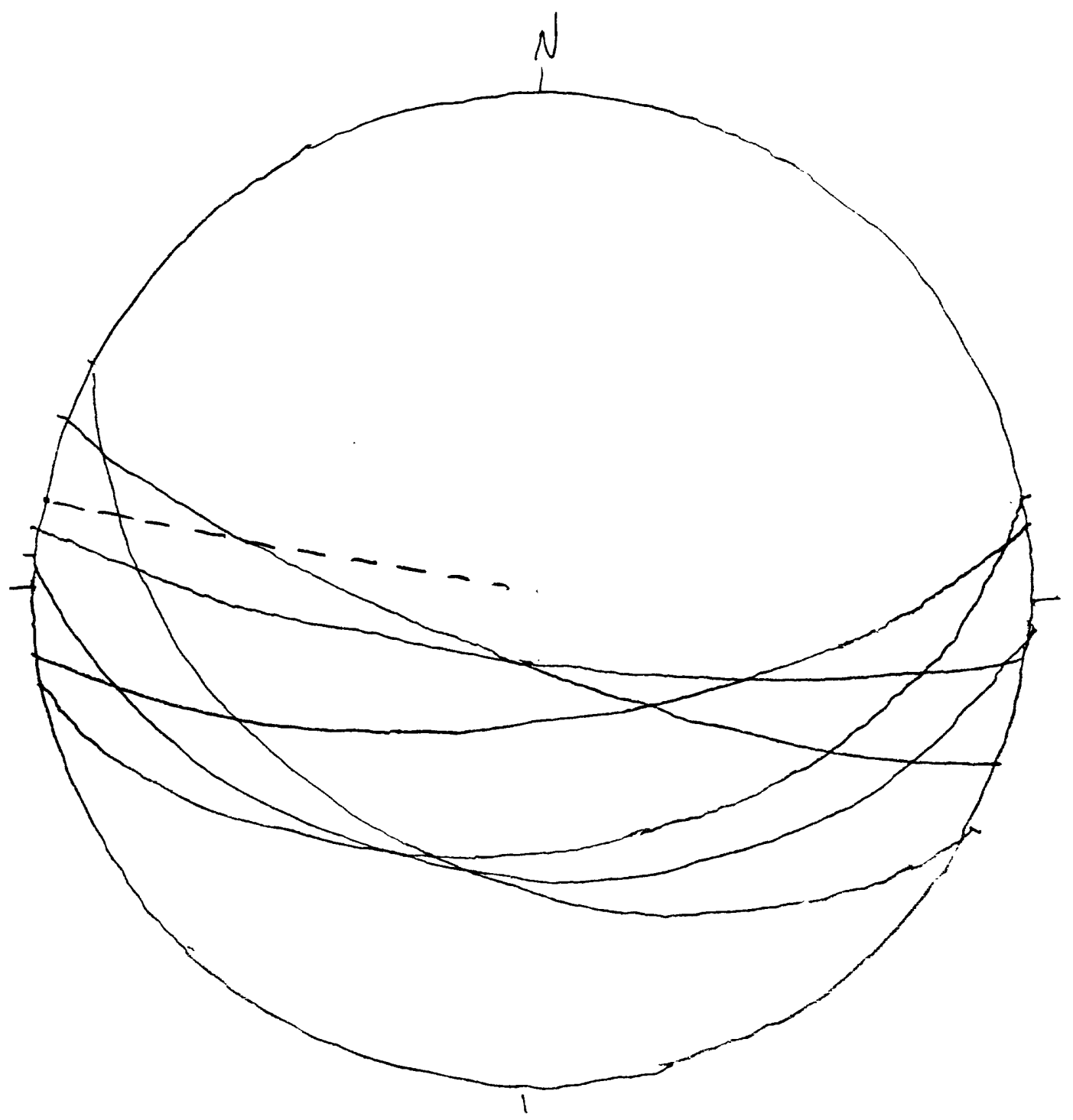

Eigure 15. Average cleavages (a), (b), and (c) in Domain 3 , Eigure 15. Average cleavages (a), $(b)$, and (c) Average fold axis
Sunshine mine, Coeur d Alene district, Idaho. Averare
(dashed line) $=00 \mathrm{~N} 80 \mathrm{~W}$. Schmidt net, lower hemisphere. 
Erom a set of 363 bedding attitudes, 100 were selected at random for structural geometric analyeis. Figure 16 is a PI diagram, showing a rather diffuse girdle pattern; its pole, $16 \mathrm{~S} 52 \mathrm{E}$, provides an estimate of the average fold axis trend for the subarea. Figure 17 is a BETA diagram for the same data. The dominant fold trend for the area lies near $20 \mathrm{~S} 34 \mathrm{E}$. Thus, shown by two diagrams, the folds in this area trend dominantly at a shallow plunge near S.35E (Fig. 17 is the stronger indicator).

The average fold axial plane lies nowhere near the girdle from the cleavage. Here, the strongest cleavage, of near-N65W trend like that of cleavage elsewhere in the district, cuts across folds of different orientation and northerly trend. Elsewhere, as at the Big Creek and Lookout anticlines (see Fig. 1 ; the latter feature is described below), the cleavage cuts across folde of more westerly trend (Eigs. 18 and 19).

The slip line operative during cleavage development is considered next. Hobbs and others, 1965 , p. 121 , remarked a dipline lineation in the (regional) cleavage, consisting of "elongated mineral grains, mineral streaks, and fragments of more competent rocks". This may be characterized as a stretching lineation for slip along the dip line. Similar features were noted farther east along the Osburn fault, in western Montana (Wallace and Hosterman, 1956, p. 600): Cleavage trending from N45W to N7OW and dipping steeply to the southwest commonly contains a lineation that plunges down the line of the dip.

To further the analysis, we collected two oriented specimens, one north of the Osburn fault and in the Prichard Formation at Big Creek (Fig. 1), and one south of the Osburn fault in the St. Regis Formation near the Galena mine (Fig. 1), both in the regional, N65W cleavage; they show similar petrographic features.

A fine-grained schistosity or slaty cleavage cuts bedding and dips rather steeply to the south. This is the general cleavage seen at the outcrop and is assigned to $S 2 b$, later than relics of the earlier, weak, near-bedding-parallel schistosity (S1) shown here by muscovite-chlorite-biotite. Biotite is partly altered to chlorite and epidote. Very fine sericite characterizes S2b. Sericite flakes lie in a weak schistosity, weak because most flakes lie in an axial array intersecting in the dip line. Some leucoxene and magnetite occur in tiny rods lying in a stretch lineation parallel to the dip line. Chlorite flakes lying in $S 1$ show rotation both clockwise and counterclockwise (looking west) in the cleavage, although "clockwise" grains are dominant.

Next we examine bedding-cleavage relations farther east, in the Lookout anticline subarea (Eig. 1), south of the Osburn fault. This subarea covers that part of the Lookout anticline (Hobbs and others, $1965, \mathrm{p} .113$ ) in the northeast quarter of the Wallace quadrangle (Foster, 1983, Plate 1; and Hobbs and others, 1965, Plates 4 and 5), in the area between the Osburn and the Placer Creek (Fig. 1) faults. Bedding and cleavage orientations were compiled from the geologic maps given in the referenced Plates. The data set is given in Appendix 2. 


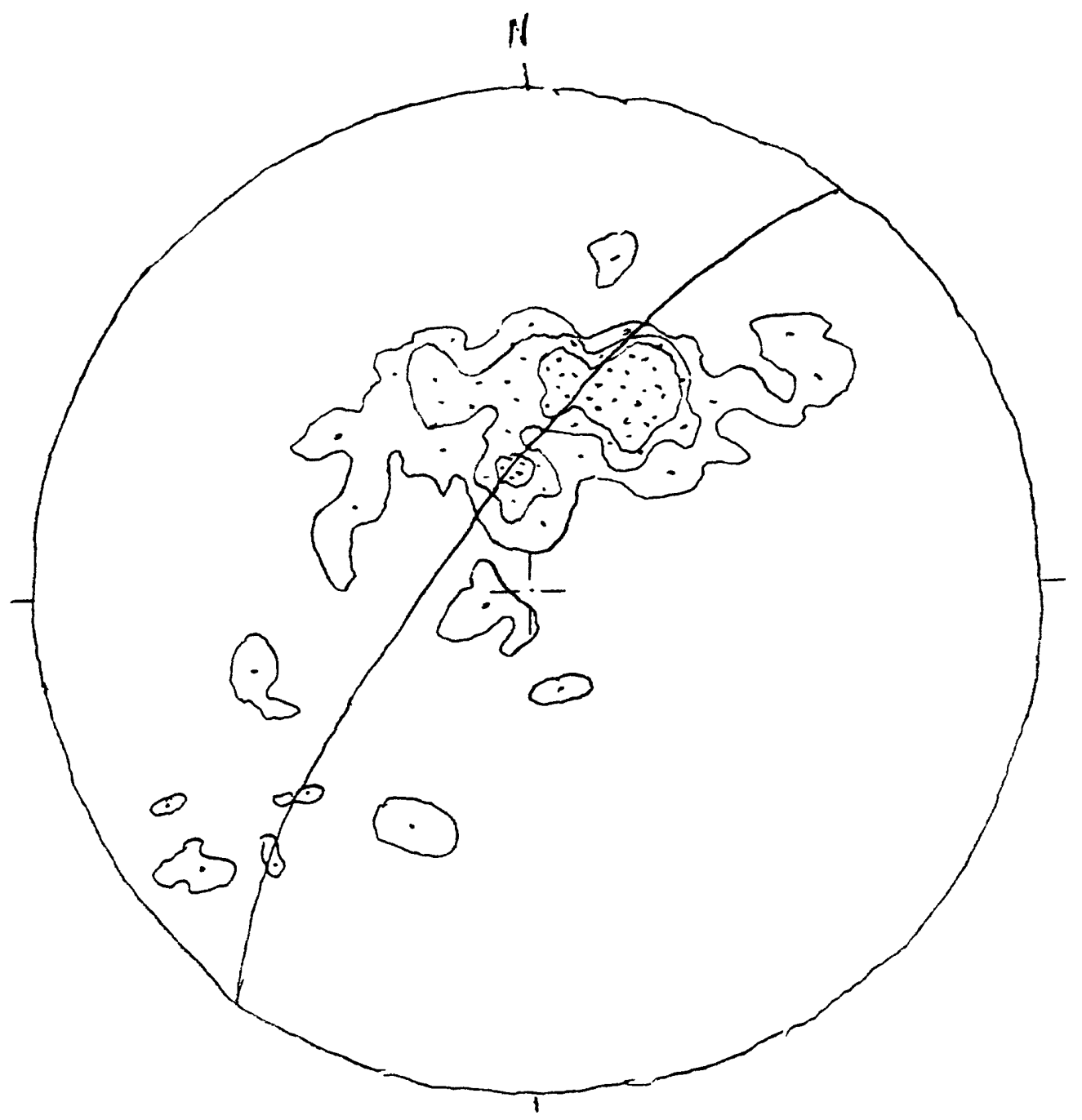

Figure 16. PI diagram, bedding, Sunshine subarea, Coeur d' Alene district, Idaho. $N=100$. Girdle oriented $\mathrm{N} 38 \mathrm{E} 74 \mathrm{NW}$. Contours at 2, 4, $6 \%$ per $1 \%$ area. Schmidt net, lower hemisphere. 


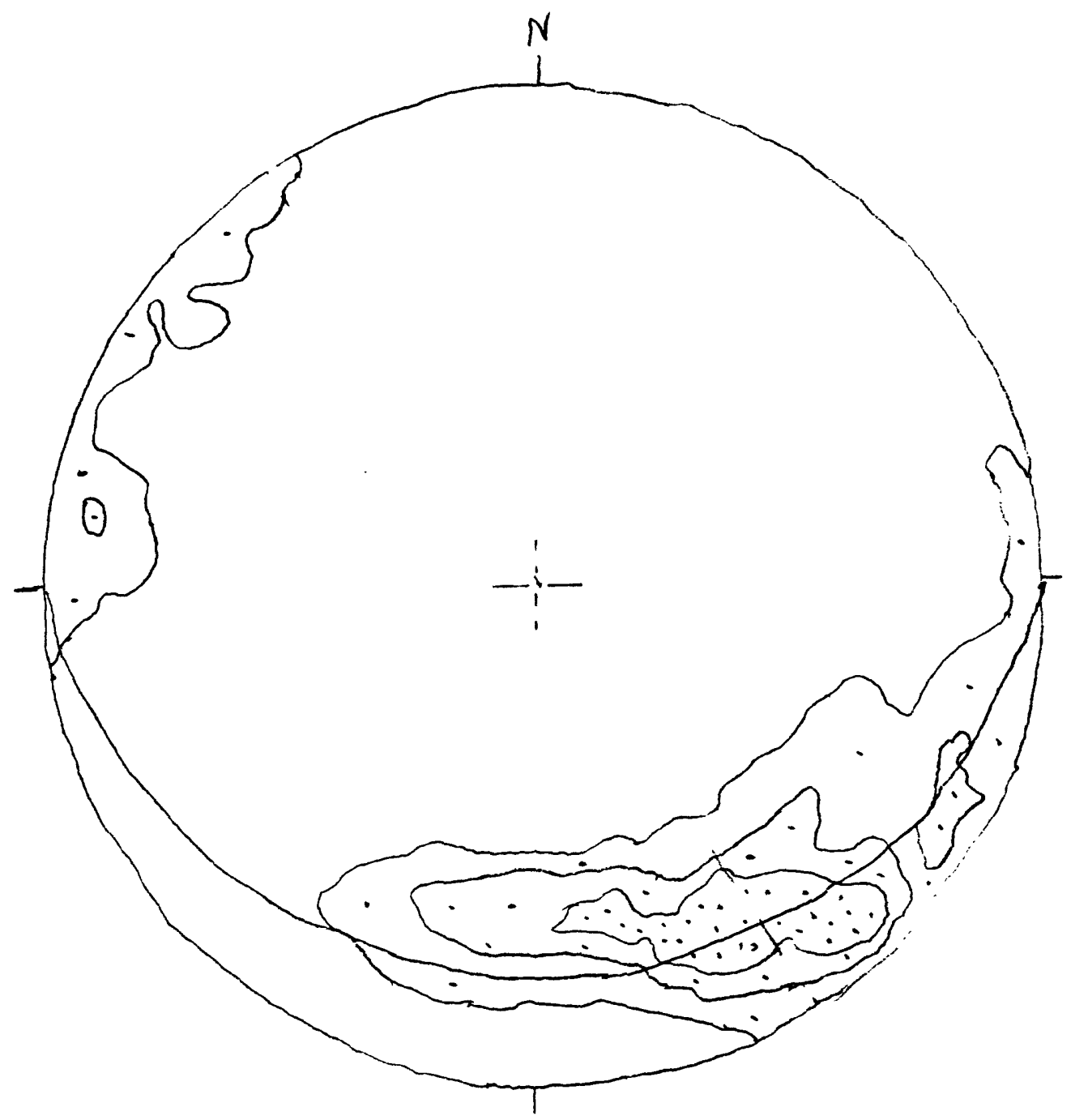

Figure 17. BETA diagram, bedding, Sunshine subarea, Coeur d' Alene district, Idaho. $\mathrm{N}=4950$ points from intersections of 100 planes. Girdle at N9OE 23S. BETA maximum 22 S33E. Contours at $1.5,3.0$, and $4.5 \%$ per $1 \%$ area. Schmidt net, lower hemisphere. 


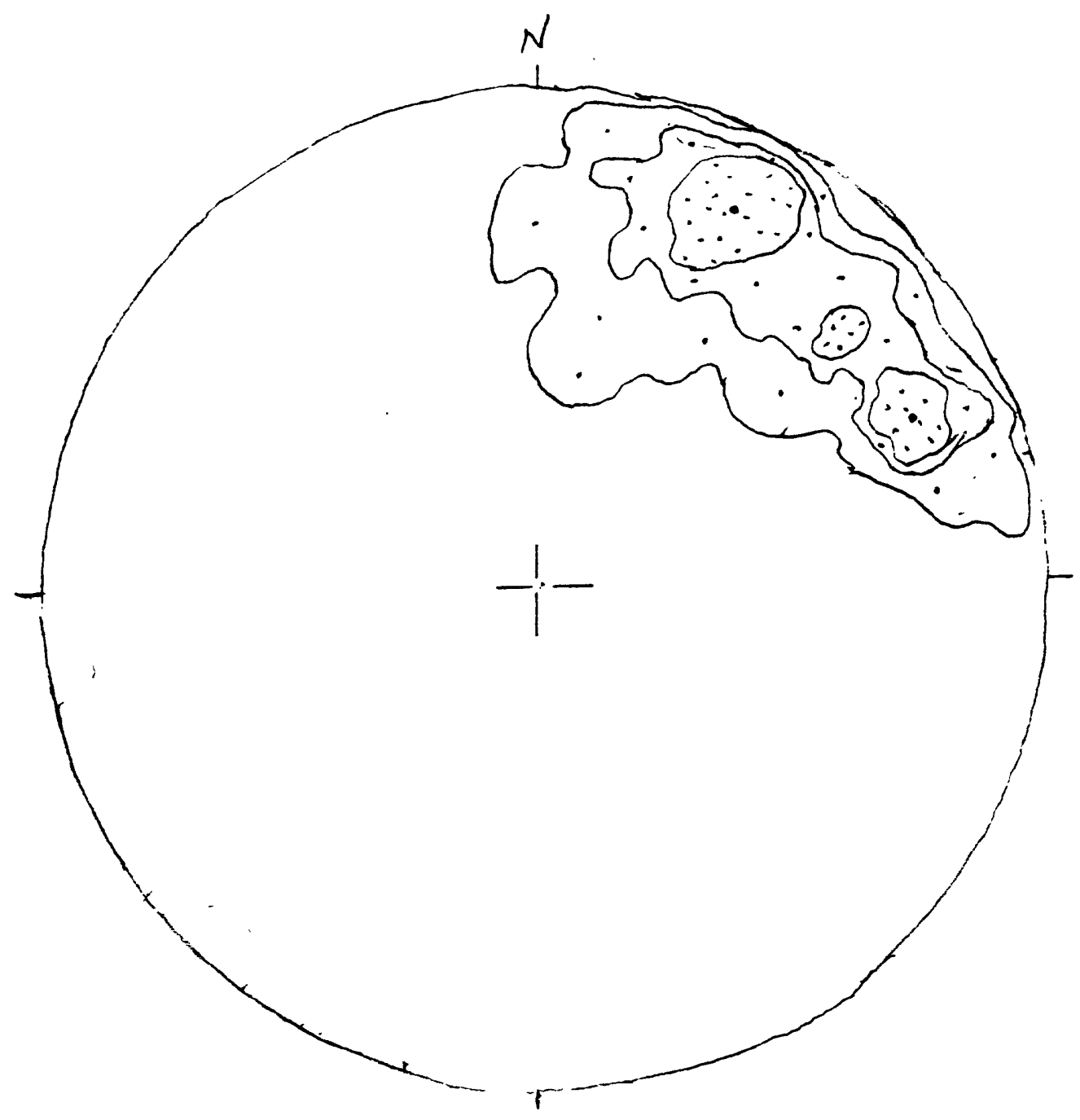

Eigure 18. PI diagram, cleavage, Sunshine subarea, Coeur $d^{\text {. }}$ Alene district, Idaho. $N=76$. Contours at $2.5,5.0$, and $7.5 \%$ per $1 \%$ area. Schmidt net, lower hemisphere. 


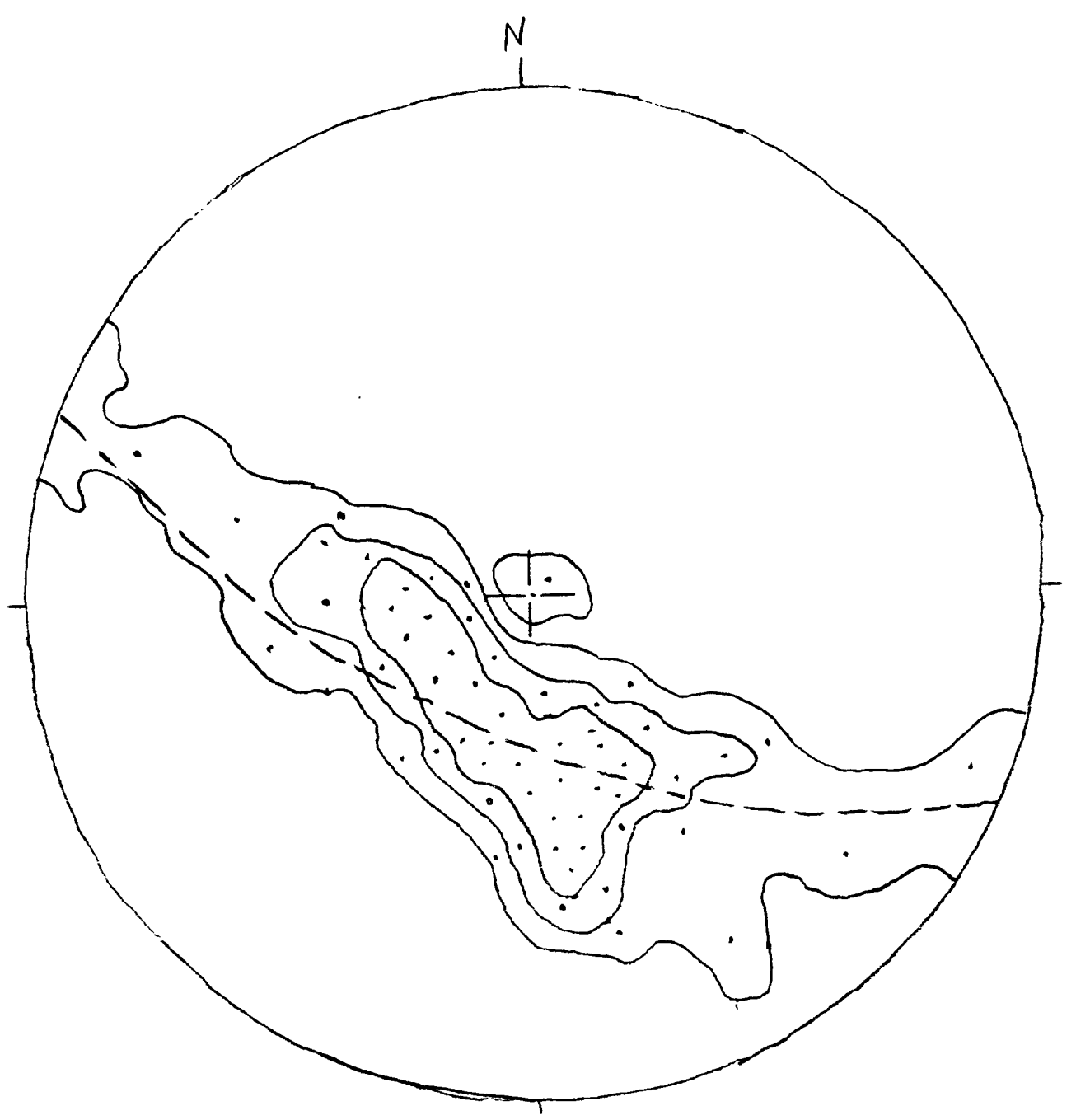

Eigure 19. BETA diagram, cleavage, Sunshine subarea, Coeur d' Alene district, Idaho. $N=2850$ points from intersections of 76 planes. Girdle N65W 67SW. See discussion in the text. Contours at $1.5,3.0$, and $4.5 \%$ per $1 \%$ area. Schmidt net, lower hemisphere. 
The axial trend of the Lookout anticline is $N 75 \mathrm{~W}$, and its axis is nearly horizontal (Eig. 20). The dip of the axial plane does not emerge from Eigure 20; however, from the cross-section given by Hobbs and others, 1965 , Plate 5 , it is about $75 \mathrm{SW}$. The north limb of the fold is overturned in places, as shown in the cross-section. Figure 21 shows that the Lookout anticline is essentially concentric about its $\mathrm{N} 75 \mathrm{~W}$ axis.

Ninety-five cleavages from the Lookout anticline subarea are given in Figure 22. Strikes and dips show a rather wide range: strikes between about N8OE to about N35W, with an average near N60W; similar to cleavage trends in the Sunshine subarea. Dips average near vertical, but occur up to $60^{\circ}$ both to the southwest and the northeast.

Two generations of cleavage, one axial planar and one faultrelated, may be concealed in the PI plot of Figure 22; if so, two average shear planes might be present. This possibility can be tested in a BETA plot, on the view that two generations of cleavage (non-parallel) would show intersections in two shear sets and thus generate two girdles in a BETA plot. The BETA plot for the Lookout anticline cleavage is given in Figure 23 . A single girdle emerges; this indicates a single symmetry (sigma 2sigma 3) plane and thus a single generation of cleavage. That average plane is oriented near N6OW 90. A possible shear plane averaging in the axial plane of the Lookout anticline (N75W, $75 \mathrm{SW}$ ) does not emerge.

\section{High-strain Zone}

Much evidence exists to show that at least a part of the broad fault framework of the Coeur $d^{-}$Alene district formed prior to or during mineralization. As a part of that framework, this project has delineated a broad zone of high strain adjacent to and along the north side of the Osburn fault (Eig. 1), placed in D2b. Dip steepness (intensity), as a measure of strain

intensity, serves to identify the northern zone boundary. Mean dip intensity averaged in subareas and contoured (diagrams not reproduced here) provides the necessary estimates, giving rise to the northern zone boundary sketched in Figure 1 . The southern boundary line lies near and nearly parallel to the Osburn fault (Eig. 1).

A transect across the zone north of Kellogg (Kellogg area) is described first. For the Kellogg area discussion, bedding and cleavage orientations used are from Hobbs and others, 1965, Plate 2 , and solely from the Prichard Formation north of the Osburn fault, in the zone of high strain. From our mean dip intensity analysis of data given by Willoughby, 1986, Plate 1 , it is seen that the northern boundary of the zone lies near the center of the quadrangle (Eig. 1), and thus close to the north side of Section 27, e.g., in upper Montgomery Creek (Eig. 1). Dips are significantly steeper in the zone than out of it to the north, and structural geometry shows fold styles and trends to be markedly different, in the two zones: NOOW in the area to the north and WNW within the zone. From Figure 1, the zone is about, three miles wide in the Kellogg area. 


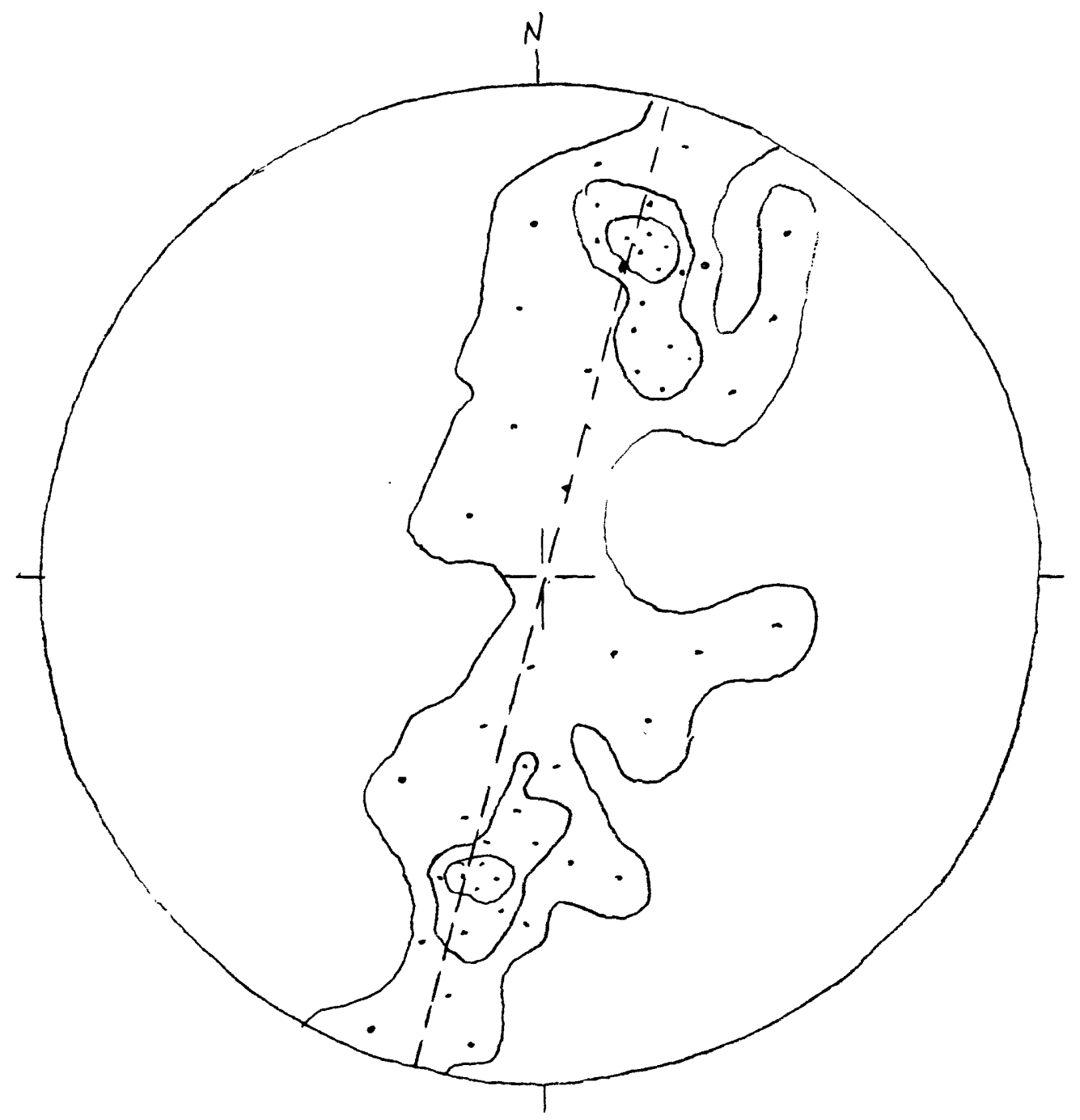

Eigure 20. PI diagram, bedding, Lookout anticline subarea, Coeur $d^{-}$Alene district, Idaho. $N=100$. Girdle $N 15 E$ 90SE. Contours at $2,4,6 \%$ per $1 \%$ area. Schmidt net, lower hemisphere. 


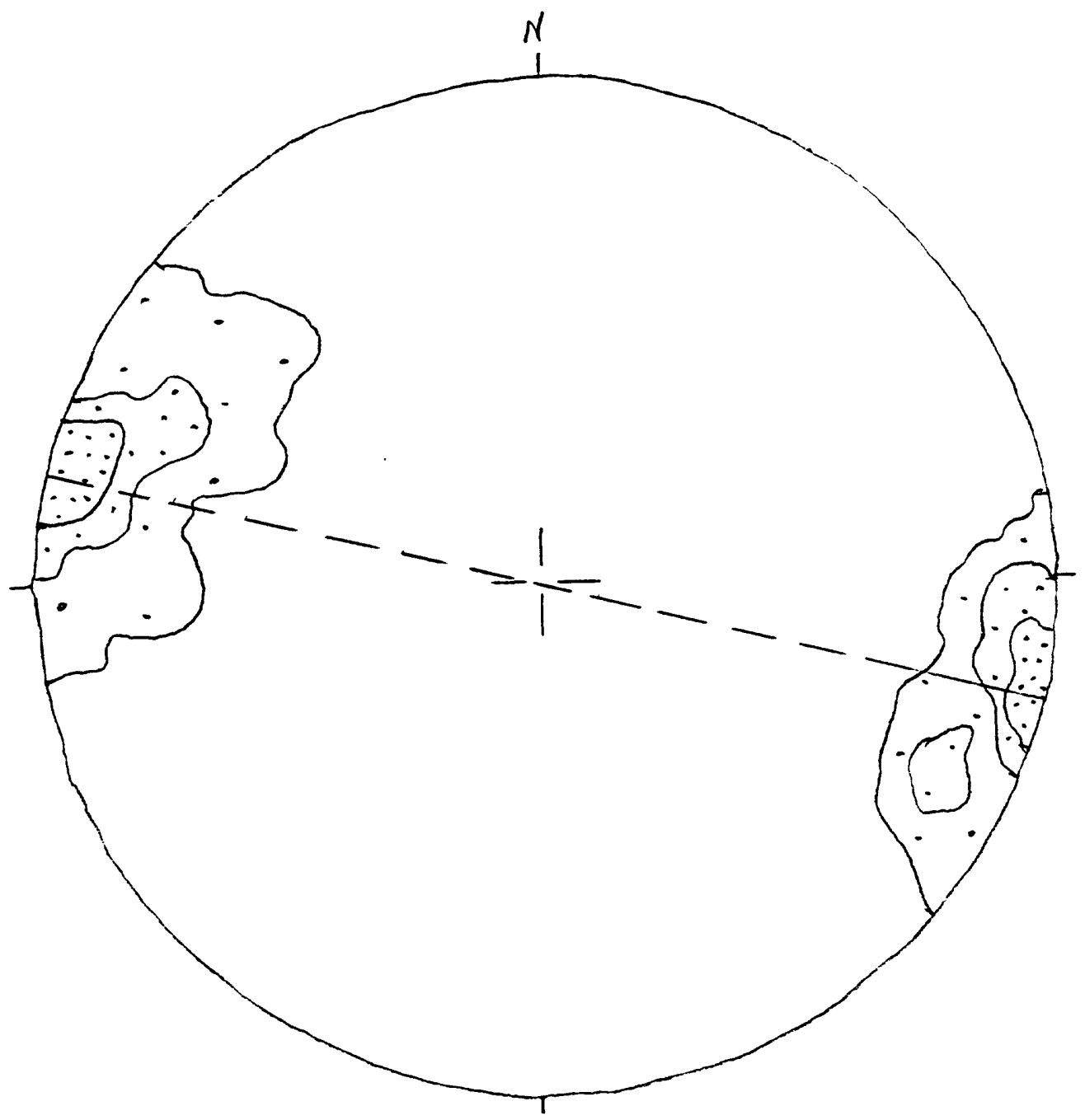

Eigure 21. BETA diagram, bedding, Lookout anticline subarea, Coeur $d$ Alene district, Idaho. $N=4950$ points from intersections of 100 planes. Fold axis $00 \mathrm{~N} 75 \mathrm{~W}$. Contours at 2 , 4 , $6 \%$ per $1 \%$ area. Schmidt net, lower hemisphere. 


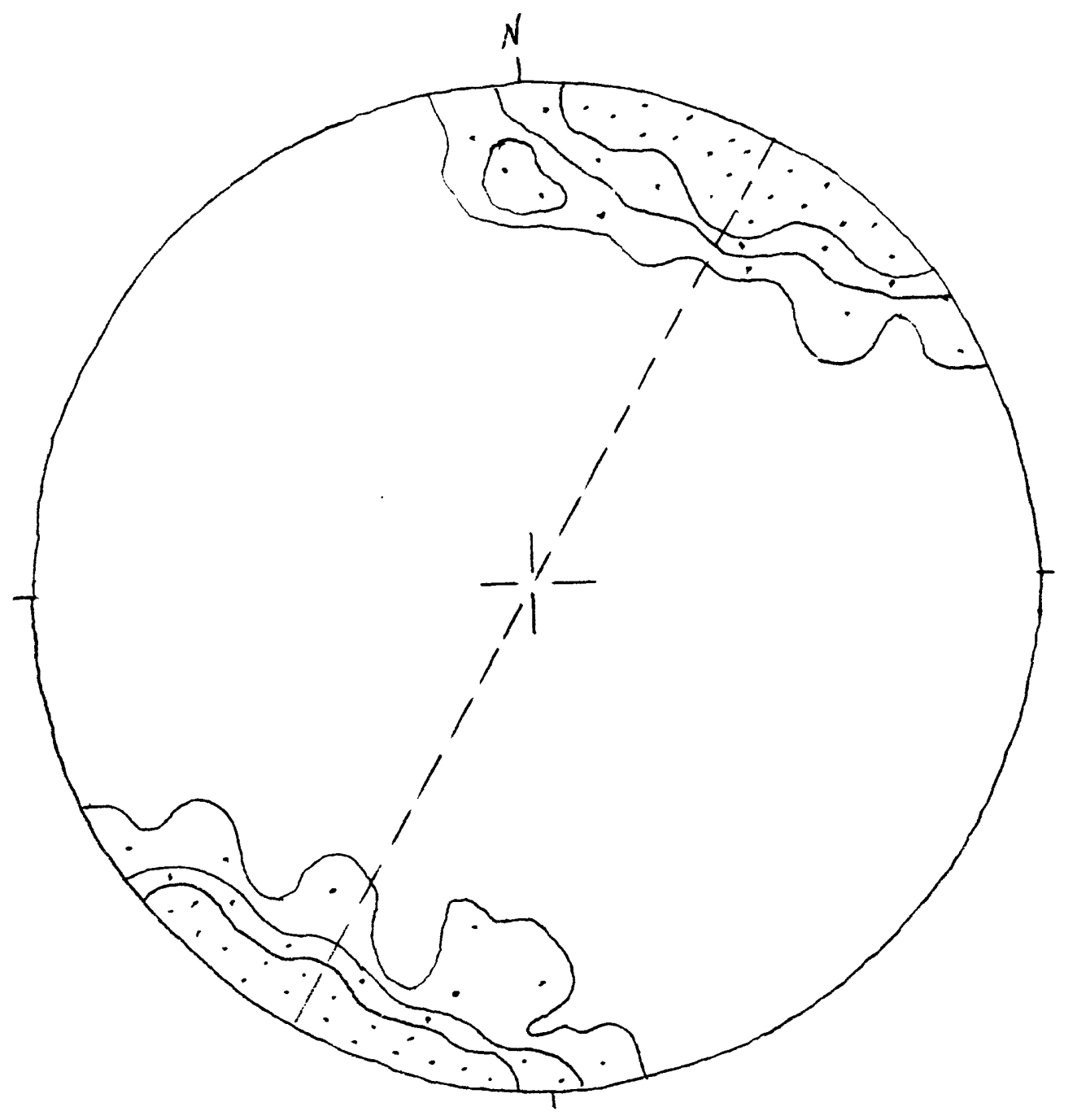

Eigure 22. PI diagram, cleavage, Lookout anticline subarea, Coeur d' Alene district, Idaho. $N=95$. Girdle N3OE 90SE. Contours at $2,4,6 \%$ per $1 \%$ area. Schmidt, net, lower hemisphere. 


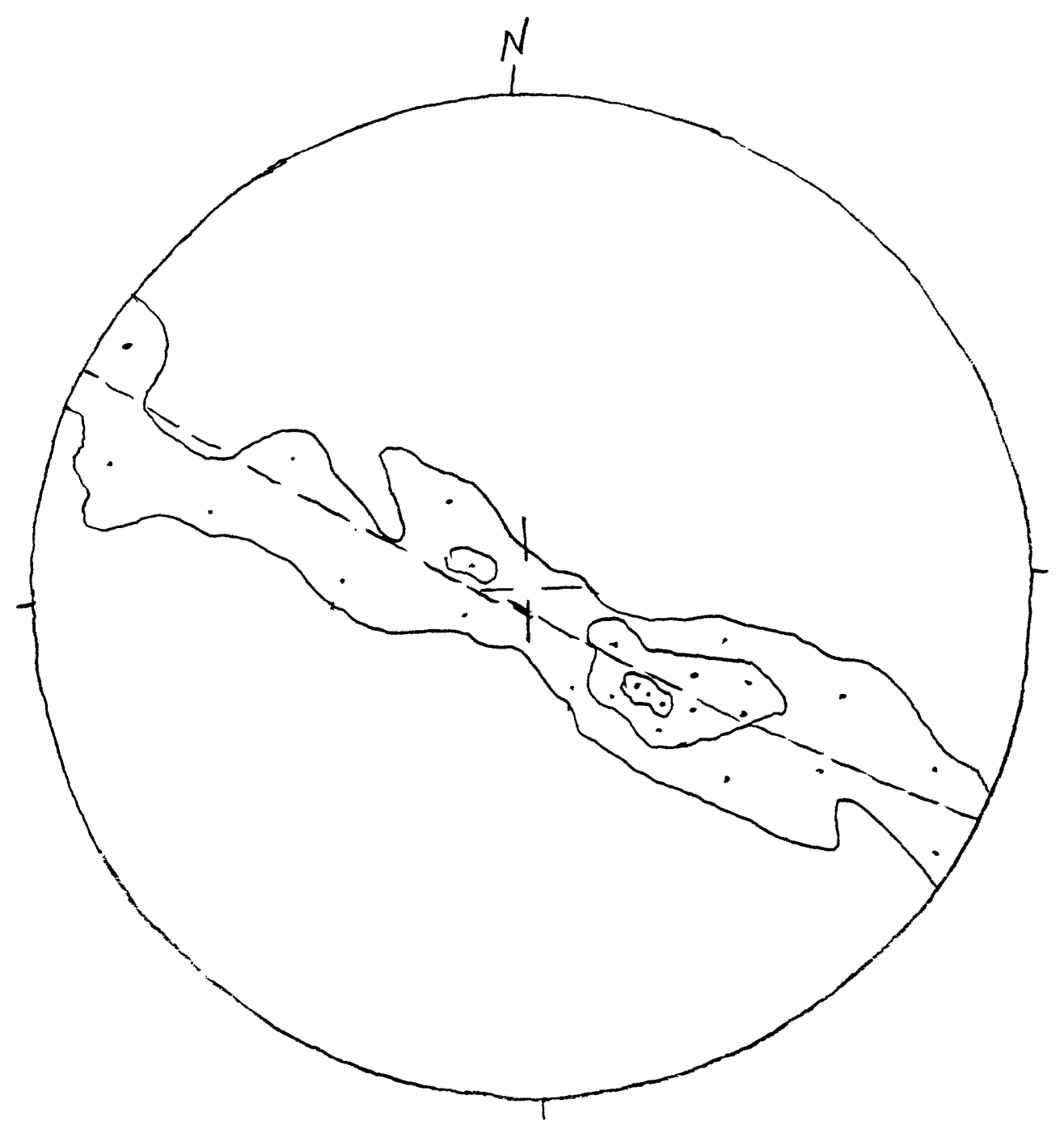

Eigure 23. BETA diagram, cleavage, Lookout anticline subarea, Coeur $d$ Alene district, Idaho. Girdle N61W 875W. $N=4465$ points from intersections of 95 planes. Contours at $2,4,6 \%$ per $1 \%$ area. Schmidt net, lower hemisphere. 
Almost every data point used from the Kellogg area of the high-strain zone shows bedding and cleavage orientations plotted very close together; the assumption is made that the attitudes represent data from single outcrops. The data set is listed in Appendix 1.

Bedding structural geometry is given in Eigures 24 and 25. Eigure 24 shows a fairly well-defined great-circle girdle, consistent with general concentric folding. Its pole, representing the average fold axis, is oriented 32 N4OW. SNET calculated an average fold axis at $29 \mathrm{~N} 35 \mathrm{~W}$ and an average axial plane at N82E 32NW. Dominant bedding orientation is N72E 32NW, also from SNET. Figure 25 gives a BETA diagram whose principal maximum indicates the dominant fold axis at $36 \mathrm{~N} 40 \mathrm{~W}$ (close to the PI-derived axis in a shallow-dipping axial plane suggested by the partial girdle).

Cleavage is strongly developed in many of the argillitic beds and some more-silty beds. Calculated cleavage-bedding angles range from $02^{\circ}$ to $89^{\circ}$ in a sample of 96 measured beddingcleavage pairs, and the most frequent angles are those lying between $20^{\circ}$ and $50^{\circ}$.

The geometry of the cleavage should provide information on strain during and/or subsequent to its development. Its seeming axial-plane relation to minor folds as seen by us in a few places in the Ross Gulch subarea, discussed below, suggests that it may have developed as axial-plane cleavage in the major folds as well. Thus, if not subsequently folded, it might fan a bit but, would be generally planar, and all cleavage planes would intersect in the fold axis.

A PI diagram on the cleavage is given in Eigure 26. It shows a strong girdle, essentially parallel in its various elements to that for the folded bedding ( $F i g .24$ ). Like that in Eigure 20 , the girdle appears to be essentially of great-circle form. SNET calculated an average cleavage fold(?) axis at $39 \mathrm{~N} 43 \mathrm{~W}$, close to that calculated from folded bedding, and an axial plane(?) better interpreted as an average cleavage orientation at N12E 45NW. The two predicted axial planes, one from bedding and one from folded (?) cleavage, intersect in $30 \mathrm{~N} 24 \mathrm{~W}$. From these data, the axial plane of the folds in the bedding and the average cleavage appear to be coaxial but non-coplanar.

The situation may be examined further through a BETA diagram on the cleavage ( $E$ ig. 27). A major axis is shown at $36 \mathrm{~N} 37 \mathrm{~W}$, close to axes from Eigures 20-22. A moderately strong girdle is present, oriented N25E $40 \mathrm{NW}$.

Another structural geometric parameter is provided by the orientation of bedding-cleavage intersections, which provide measures of the orientation of fold axes(?) generated during cleavage development. The L diagram is given in Eigure 28 . Three concentrations lie in a common plane oriented N60E $33 \mathrm{NW}$. They are: (a) $32 \mathrm{~N} 40 \mathrm{~W}$, (b) $32 \mathrm{~N} 16 \mathrm{~W}$, and (c) $26 \mathrm{~N} 10 \mathrm{E}$. Concentration (a) accords well with the early bedding fold trend from Eigure 24. Concentration (b) accords reasonably well with the axis defined by the two recognized BETA girdles from bedding and cleavage, $30 \mathrm{~N} 24 \mathrm{~W}$. Concentration (c) correlates to a minor BETA orientation in Figure 25. These three lie in a plane close to that of the axial plane for folded bedding and show no 


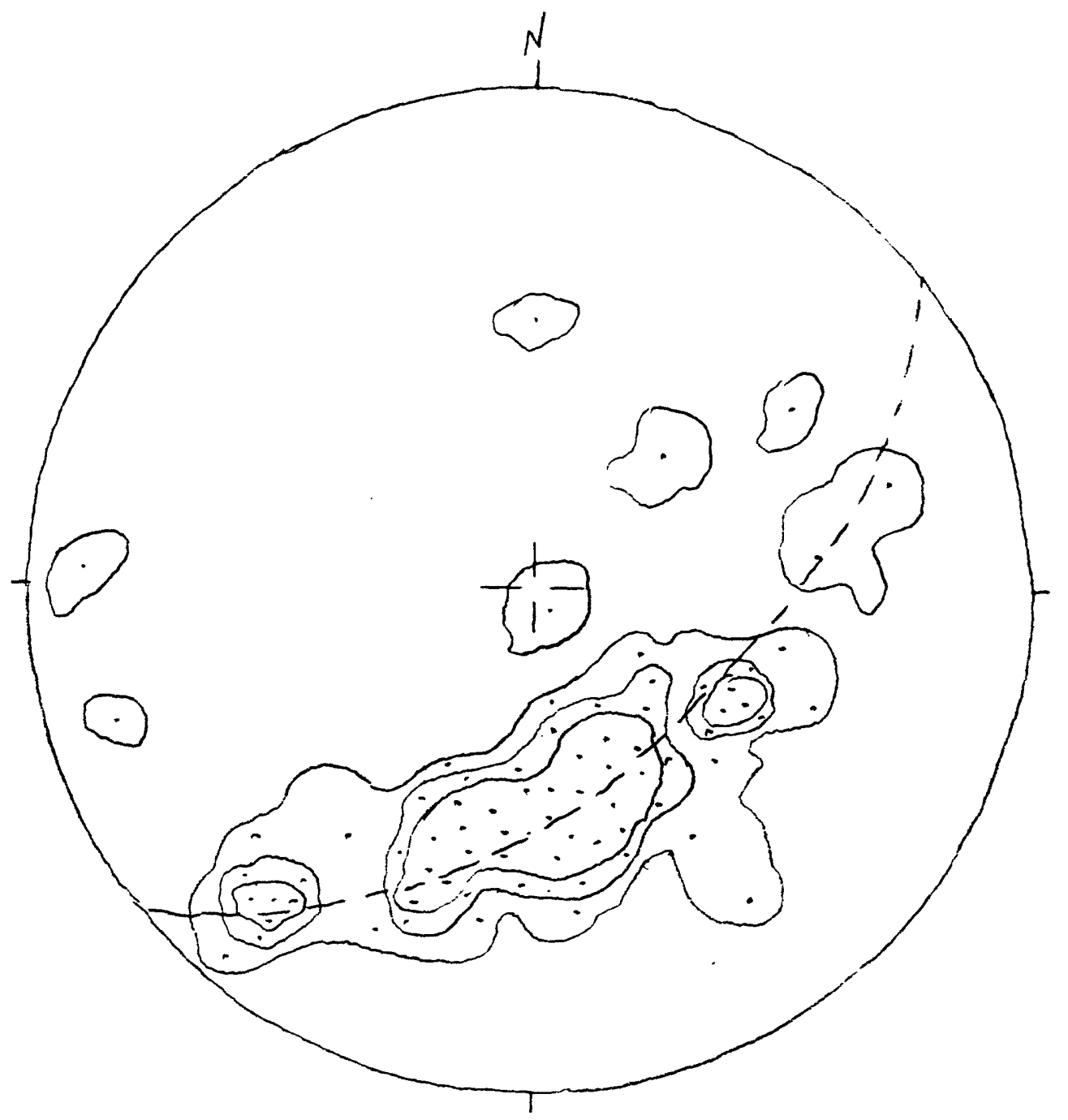

Eigure 24. PI diagram, bedding, Prichard (Kellogg) area, Coeur $d^{-}$ Alene district, Idaho. $N=95$. Girdle N5OE 58SE. Girdle pole 32 N40W. Contours at 2, 4, $6 \%$ per $1 \%$ area. Schmidt net, lower hemisphere. 


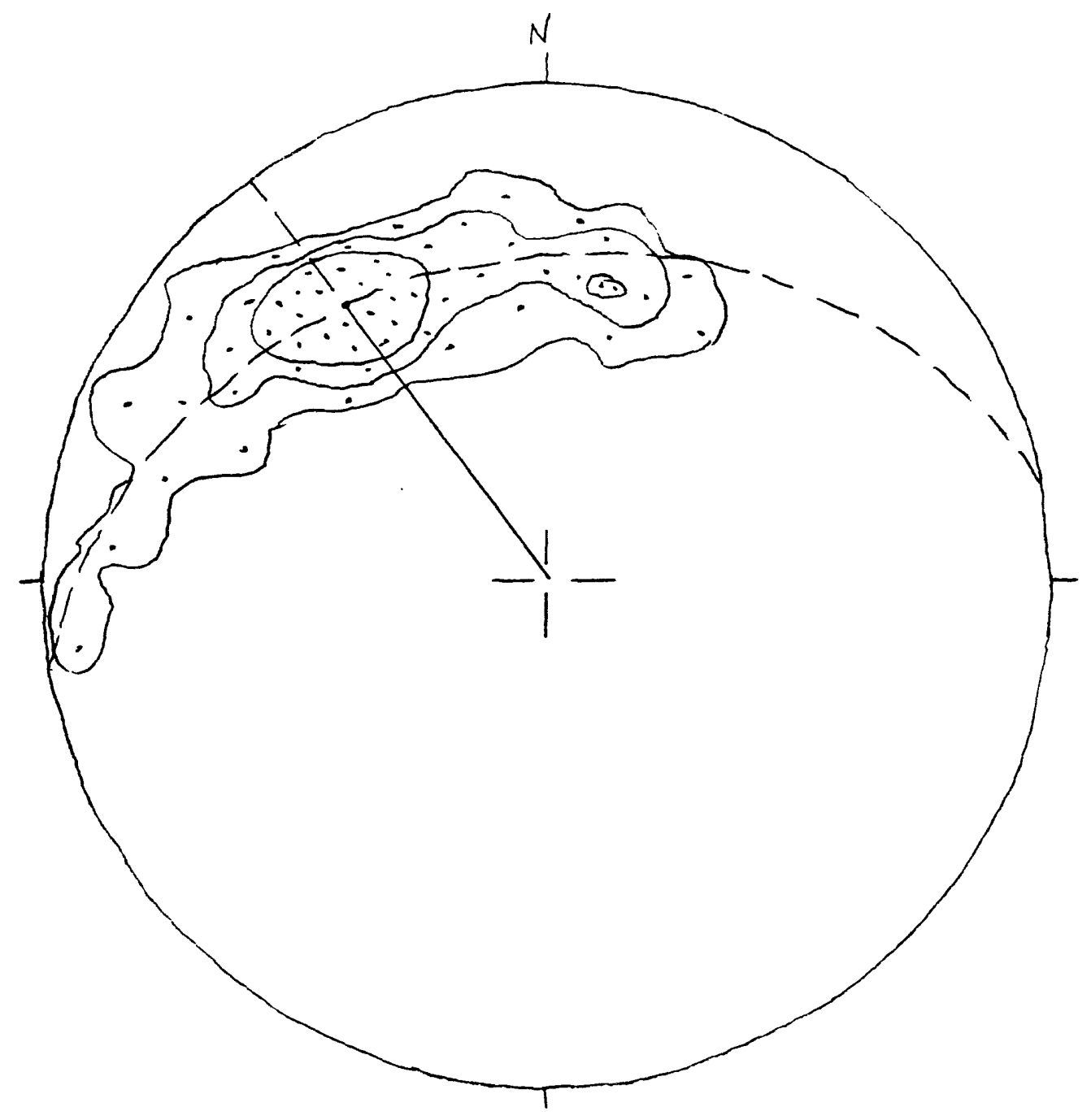

Eigure 25. BETA diagram, bedding, Prichard (Kellogg) area, Coeur d'Alene district, Idaho. Girdle N80E 35NW. Major axis 32 N36W. $N=4465$ points from intersections of 95 planes. Contours 2,4 , $6 \%$ per $1 \%$ area. Schmidt net, lower hemisphere. 


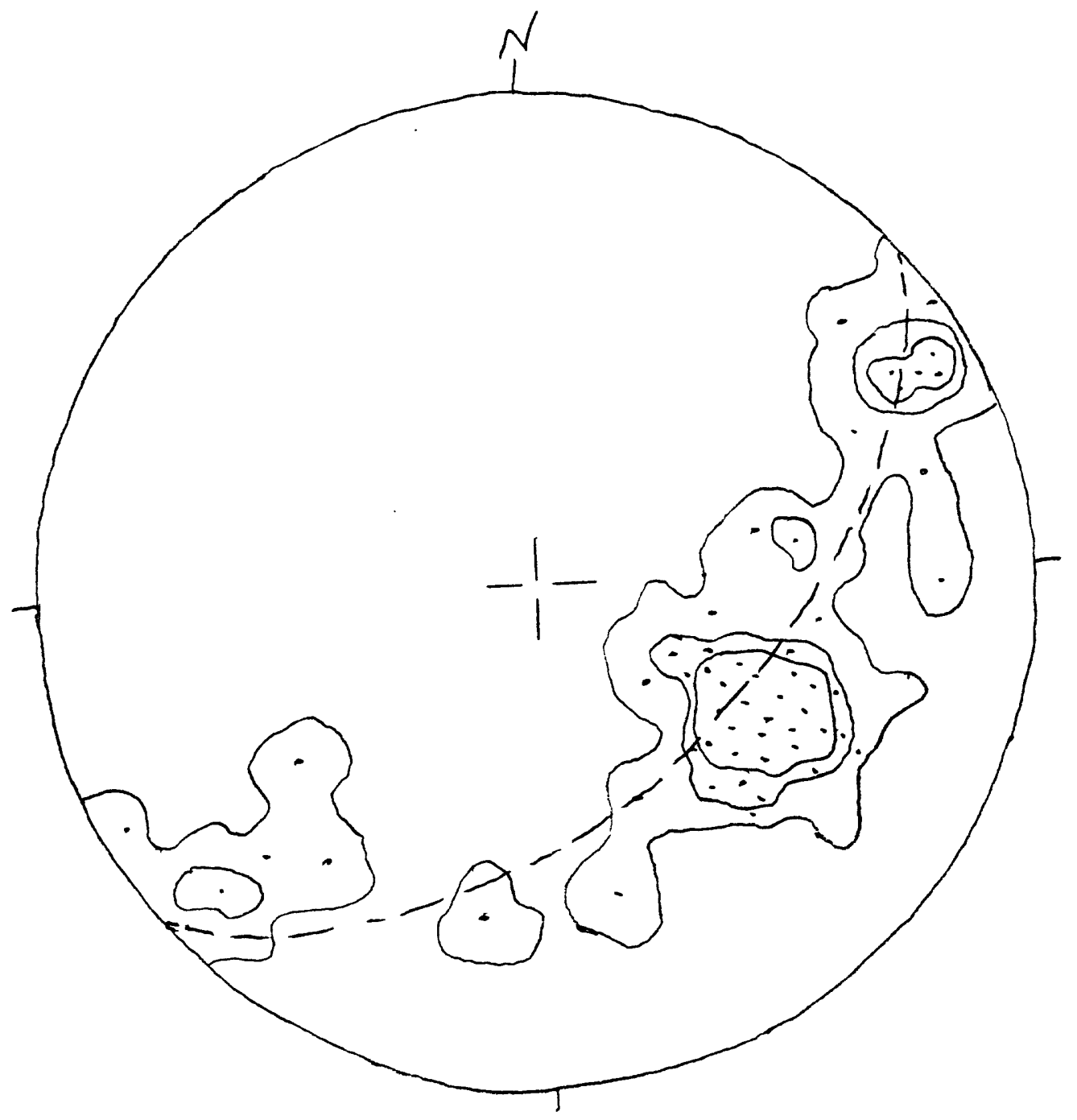

Eigure 26. PI diagram, cleavage, Prichard (Kellogg) area, Coeur d' Alene district, Idaho. $N=95$. $6 \%$ per $1 \%$ area. Schmidt net, lower pole 36 N4OW.

hemisphere. 


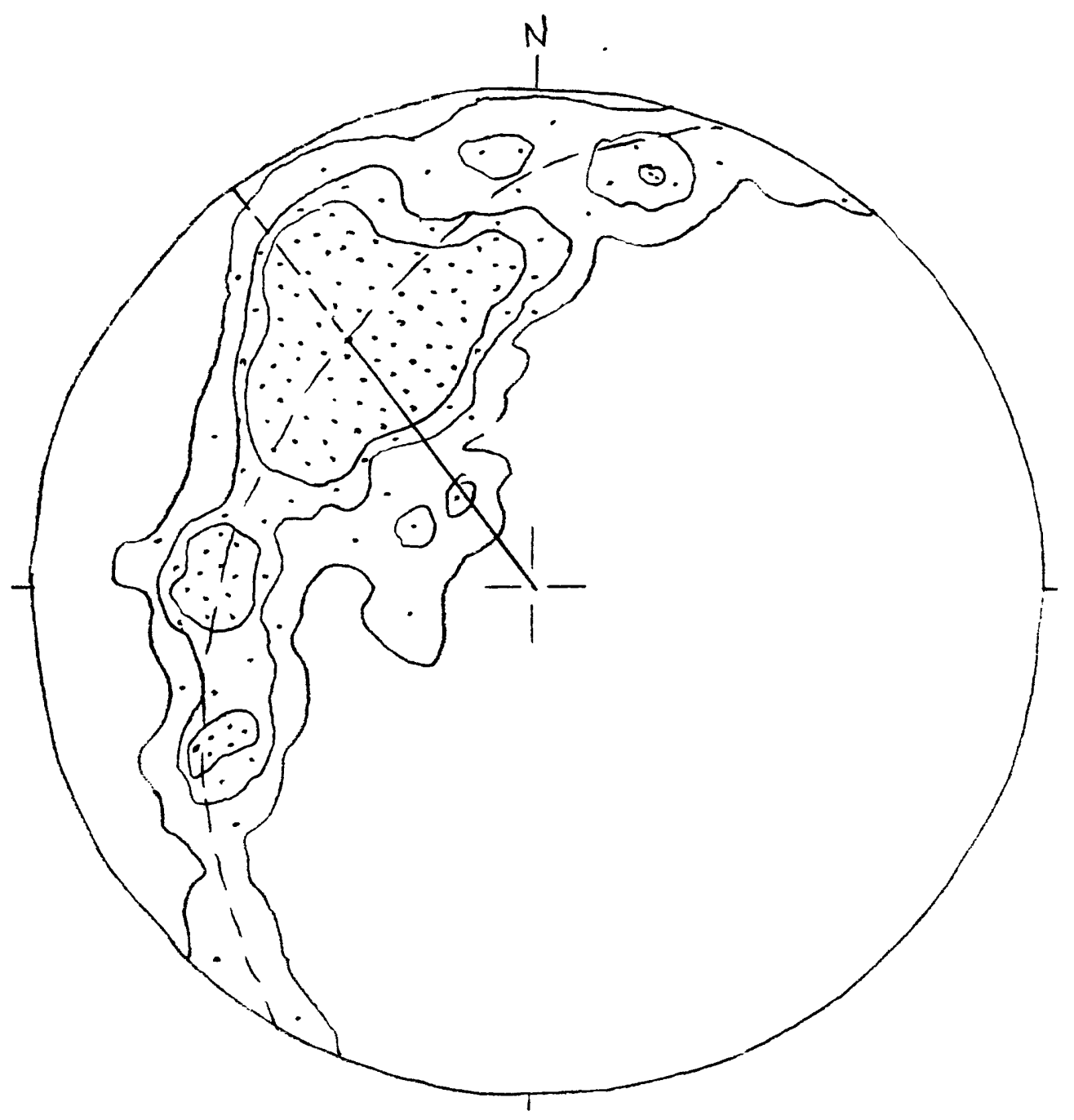

Figure 27. BETA diagram, cleavage, Prichard (Kellogg) area, Coeur d'Alene district, Idaho. Girdle N25E 40NW. Axis $36 \mathrm{~N} 37 \mathrm{~W} . \mathrm{N}=$ 4465 points from intersection of 95 planes. Contours at $1,2,3 \%$ per $1 \%$ area. Schmidt net, lower hemisphere. 


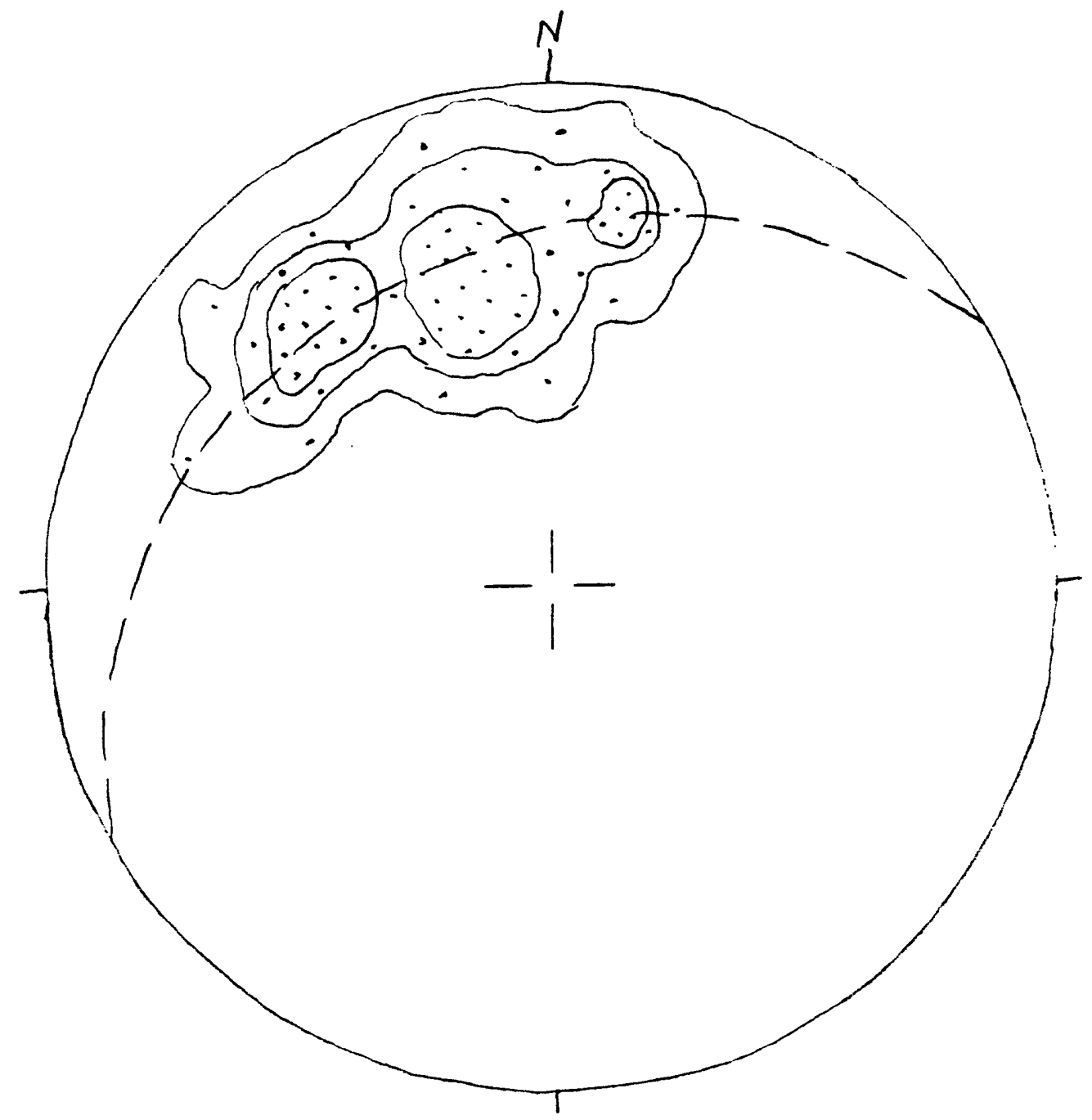

Figure 28. Bedding-cleavage intersections, Prichard (Kellogg) area, Coeur $d^{-}$Alene district, Idaho. $\mathrm{N}=96$. Girdle N6DE $33 \mathrm{NW}$. Point concentrations at $32 \mathrm{~N} 42 \mathrm{~W}, 32 \mathrm{~N} 16 \mathrm{~W}$, and $26 \mathrm{~N} 10 \mathrm{E}$. Contours at $2,4,6 \%$ per $1 \%$ area. Schmidt net, lower hemisphere. 
substantial relation to the axial plane for folded(?) cleavage.

The observed, seeming axial-planar relation of cleavage in some minor folds requires further consideration. A related point comes from the detailed analysis of the Ross Gulch subarea, discussed below. Minor folds there appear partly incongruous, and at first appearance might not be related to the early fold phase. Their axial-plane(?) cleavage shows them seemingly to be later-synchronous with cleavage development.

The Ross Gulch subarea (Eig. 1), near Kellogg, in the TEZ, is investigated next, to compare structure in a small part of the zone to that of the entire zone near Kellogg. A possible secondorder anticline occurs in the south 0.25 miles of the spix west of Ross Gulch in the Prichard Formation (and that is the detailed location of the subarea), in what is called the Moon Creek anticline (Eig. 1).

Many complexities emerged in the study of bedding-cleavage relations in the Ross Gulch subarea, too numerous to detail here. The general results are encapsulated in Figure 29 , and the detailed descriptions are placed in Appendix 5. The general features of the subarea show a seemingly random set of angular relations between bedding and cleavage. That seeming randomness, however, proves to be resolved into an axially symmetric fabric; both the bedding and the cleavage share this axis, but the cleavage has no symmetrical relation to the folds in the bedding. The subarea fabrics are similar to those of the Kellogg area, however.

The trend of the postulated high-strain zone through the Coeur $d$ " Alene district is considered next; it can be tested in part through the structural geometry of bedding and cleavage fabrics in two subareas defined below, Moon Creek and Terror Gulch (Fig. 1), each about three square miles in extent and shown on Hobbs and others, 1965, Plate 3 .

Many complexities exist in detail in these two subareas, too numerous to describe in the text. Thus, the details are placed in Appendix 5. From the structural geometry of these two subareas, the general conclusion reached is that the high-strain zone trends near N7OW across the middle part of the Coeur $d^{\text {" }}$ Alene district.

A test of the possible eastern extension of the high-strain zone is available in the Burke area (Hobbs and others, 1965 , Plate 4). A parameter is available like that used to define the north margin of the high-strain zone north of Kellogg; namely, change in dip intensity across the zone margin. From a grid plot of mean dip intensity in the Plate 4 area (not shown), relatively shallow mean dips on the north pass into relatively steep mean dips to the south across a line about a half mile north of Burke. This permits extension of the north margin of the high-strain zone from the point north of Kellogg previously established, producing an average trend of N7OW across the district. Here again, cross-fault interference introduces some trend and extrapolation uncertainty. The predicted margin north of Burke is tested through structural geometric analysis of bedding and cleavage in two subareas, Tiger Peak on the north (near and north of Tiger Peak; see Fig. 1) and Burke on the soldth, taking data from Hobbs and others, 1965, Plate 4. The two subareas lie 


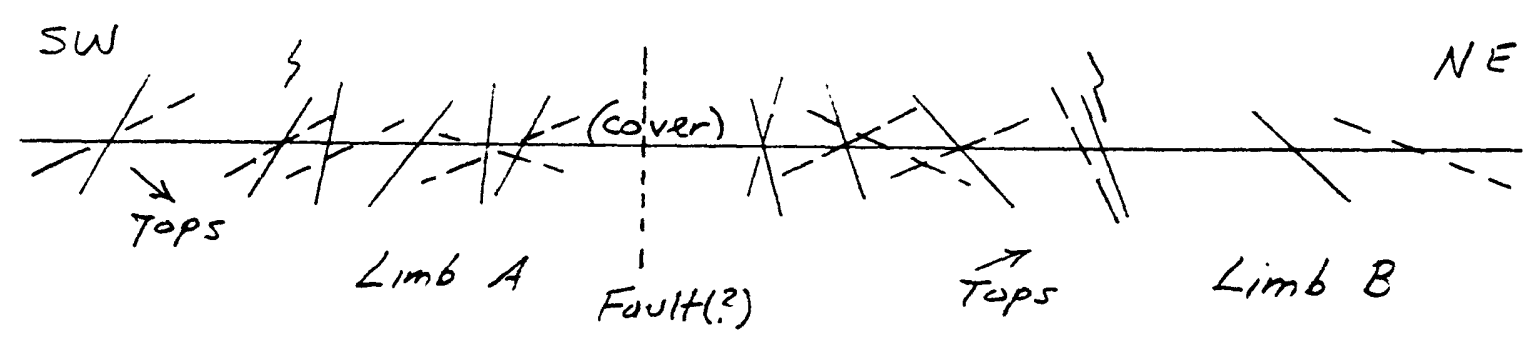

Diagrammatic interpretation:

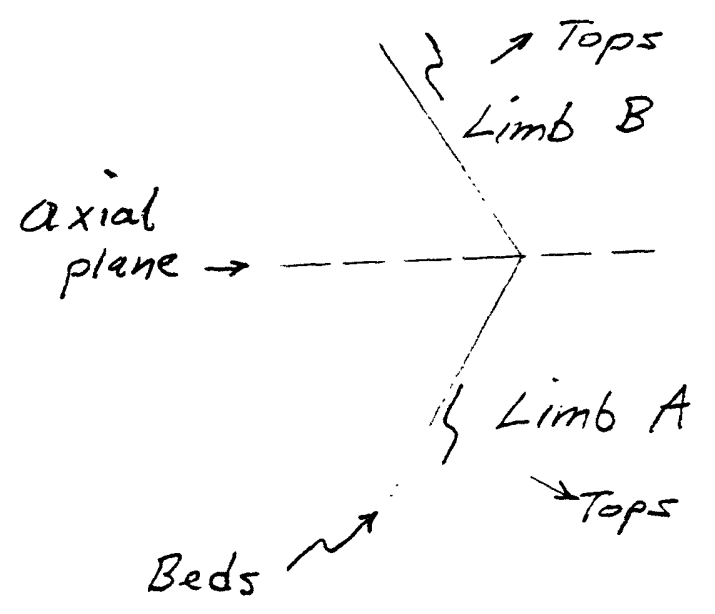

Figure 29. Profile section for one-fourth mile across the Ross Gulch subarea. Plane of section ( $35 \mathrm{E} 45 \mathrm{SE}$ ) is perpendicular to the average of the minor folds $(45 \mathrm{~N} 55 \mathrm{~W})$. Solid lines = bedding. Dashed lines = cleavage. 
within rocks of the Burke Formation, largely of thick, competent quartzite.

Structural geometry for the Tiger subarea is given first. Eigures 30 and 31 are $P I$ and BETA diagrams respectively, for bedding. Figures 32 and 33 are PI and BETA diagrams for cleavage. Structural geometry for the Burke subarea follows in the same way: Eigures 34 and 35 for bedding and Eigures 36 and 37 for cleavage.

Folding trends and intensity may be compared between the Tiger and Burke subareas. Fold trend changes from NoOW to N12W (Eigs. 30 and 34). Interlimb angles remain the same, near 70 , but folds change from cylindrical aspect ( $T$ iger) to conical (Burke), shown further in the BETA diagrams of Figures 31 and 35 .

Cleavage in the Tiger subarea, oriented N2OW $80 S W$ (Figs. 32 and 33) cuts fold axial planes (Eig. 30: NO2E 78NW) at an average angle of about $20^{\circ}$. This is compared to cleavage in the Burke subarea (Eigs. 36 and 37 ), oriented N35W $85 \mathrm{SW}$, which cuts fold axial planes oriented N12W $80 \mathrm{SW}$ (Eigs. 34 and 35 ), at an average angle of about $20^{\circ}$.

\section{Regional Cleavage Analysis}

Elow- and fracture-cleavage is reported to have formed in the rocks perhaps in two stages--one during folding (see, e.g., Hobbs and others, 1965; and Clark, 1970), although this may be weak and local; and one during faulting (see, e.g., Hobbs and others, 1965; and Vance, 1981, p. 67). Campo (1984, p. 51) described axial-plane cleavage ( $52 a$ ) in upright fold structures of the N-S Burke anticline (Fig. 1), for example. Slickenlines on the cleavage plunge down the dip line, suggesting a slip-line orientation in that direction. Slaty cleavage mapped north of the Osburn fault by Campo (1984, p. 127) cuts across the local fold trends and averages a N25W trend; close, as he put it, to the expected orientation of $S$ planes in ductile sinistral shear relative to a N80W trend for shear along the Osburn trend taken as a C plane (see Berthe and others, 1979; and Ramsay and Graham, 1970).

The Big Creek anticline (Eig. 1) is the site of an early observation involving the concept of axial plane cleavage (Shenon and McConnel, 1940). However, the concept as applied in that structure may be incorrect. Husman, 1989, p. 27, showed that flow cleavage in the Sunshine mine (which lies in the Big Creek anticline) does not "fit" the fold, but rather cuts across the fold elements in various ways although at small angles. Similar effects can be discerned on Plate 2 of Professional Paper 478 (Hobbs and others, 1965). The mapped Big Creek anticline axis is varied in trend, and local axial trends are cut across by local mapped cleavage trends. The cleavage in general shows little relation to local faults, although local angular differences are small. Clough, 1981, Plate 1, showed folds immediately to the south of the Sunshine mine mostly to average near $\mathrm{N} 75 \mathrm{~W}$ trends (Big Creek anticline trend). His analysis of "fracture cleavage" (which he took to be fault-related and which sounds like cleavage to us) shows a general N60w trend. 


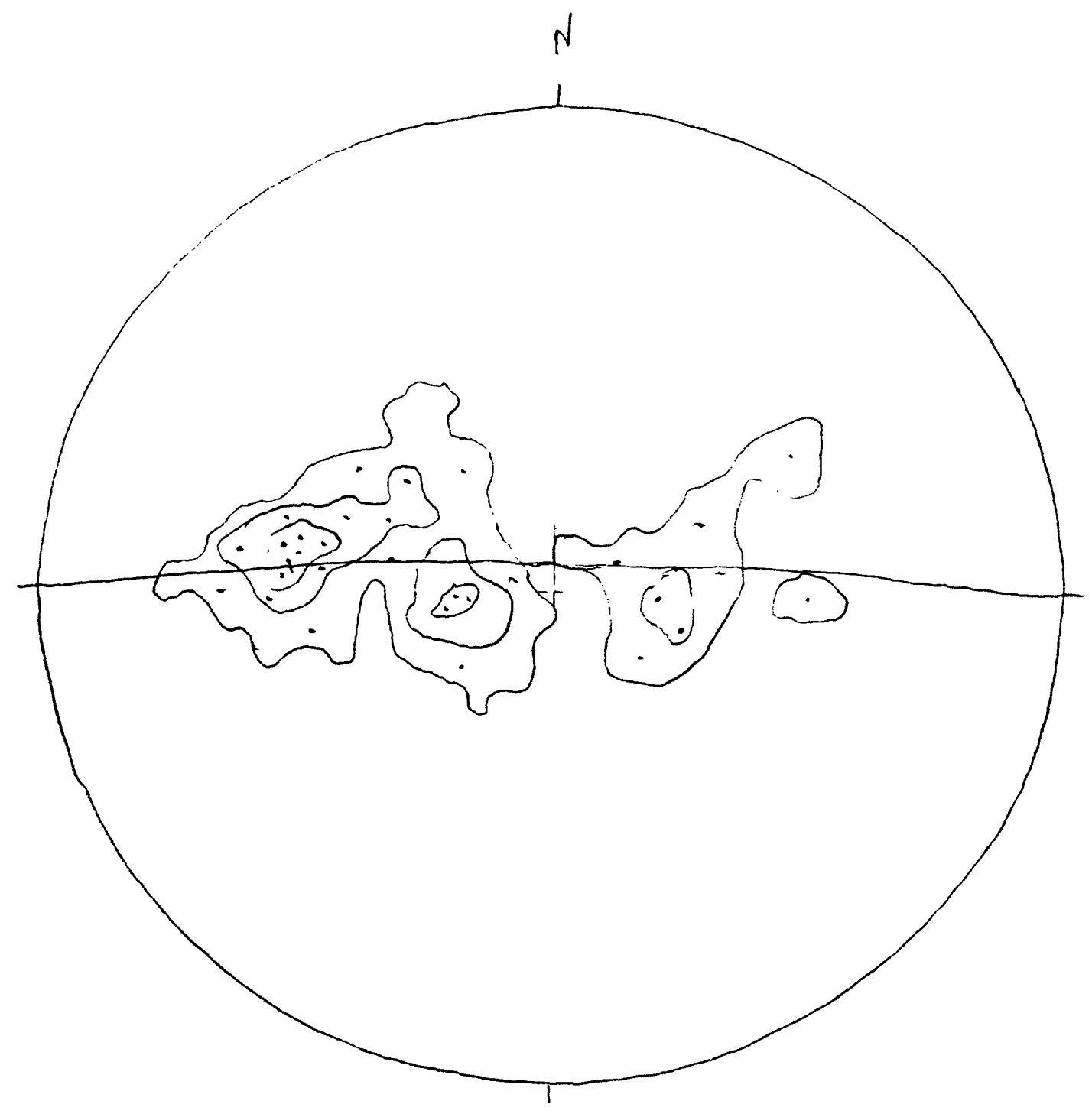

Eigure 30. PI diagram, bedding, Tiger Peak subarea, Coeur d' Alene district, Idaho. Girdle oriented N90W $85 \mathrm{~N}$. Average fold limbs are oriented N1OW 20SW, and NO7E 45NE, with an average axial plane at NO2E 7BNW. Contours at $2.9,5.8$, and $8.7 \%$ per $1 \%$ area. $\quad \mathrm{N}=95$. Lower hemisphere, Schmidt equal-area net. 


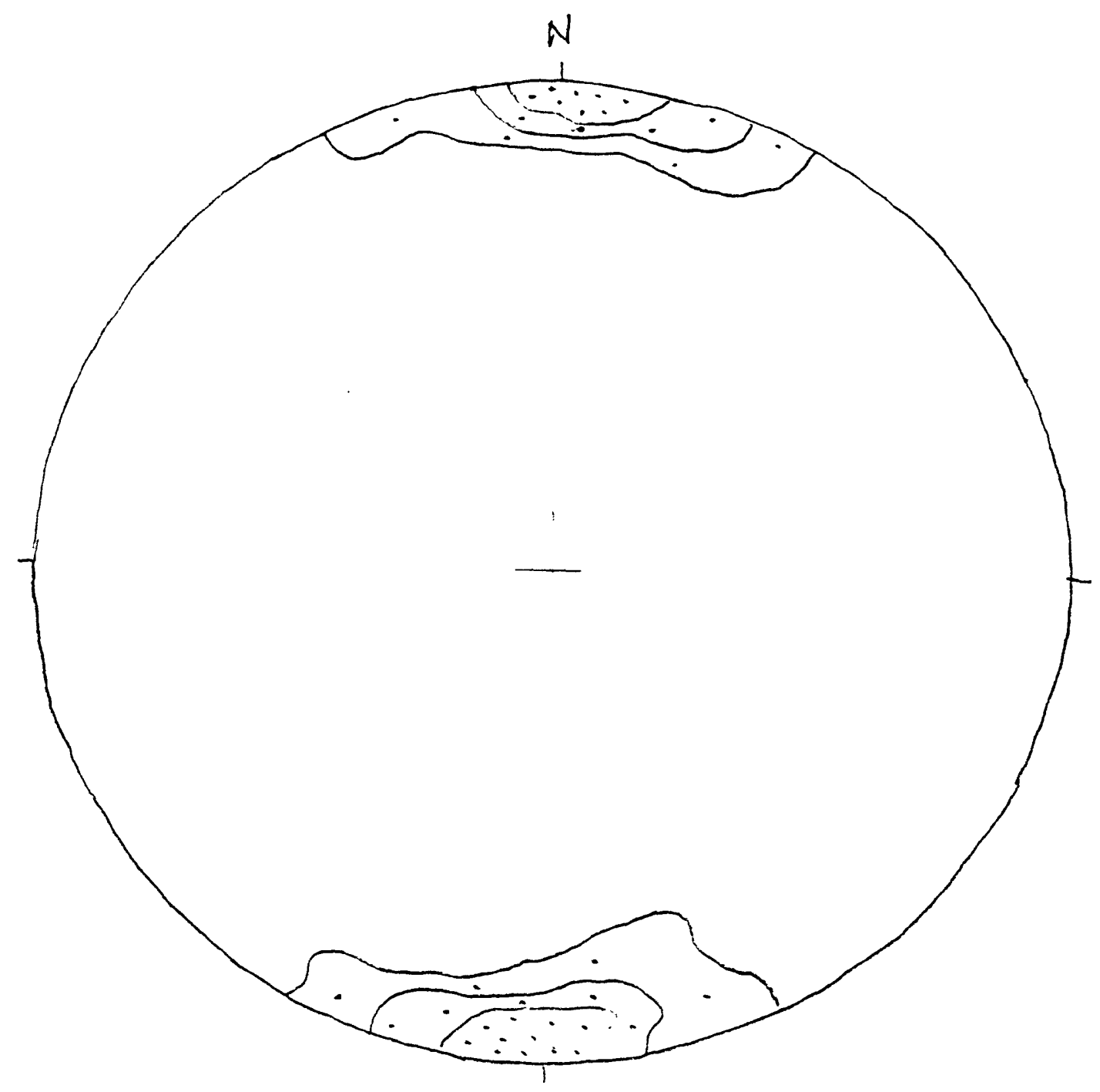

Eigure 31. BETA diagram, bedding, Tiger subarea, Coeur d' Alene district, Idaho. Fold axis near horizontal in NOOE. Contours at $2.8,5.5$, and $8.3 \%$ per $1 \%$ area. $N=4462$ from intersections of 95 planes. Lower hemisphere, Schmidt equal-area stereonet. 


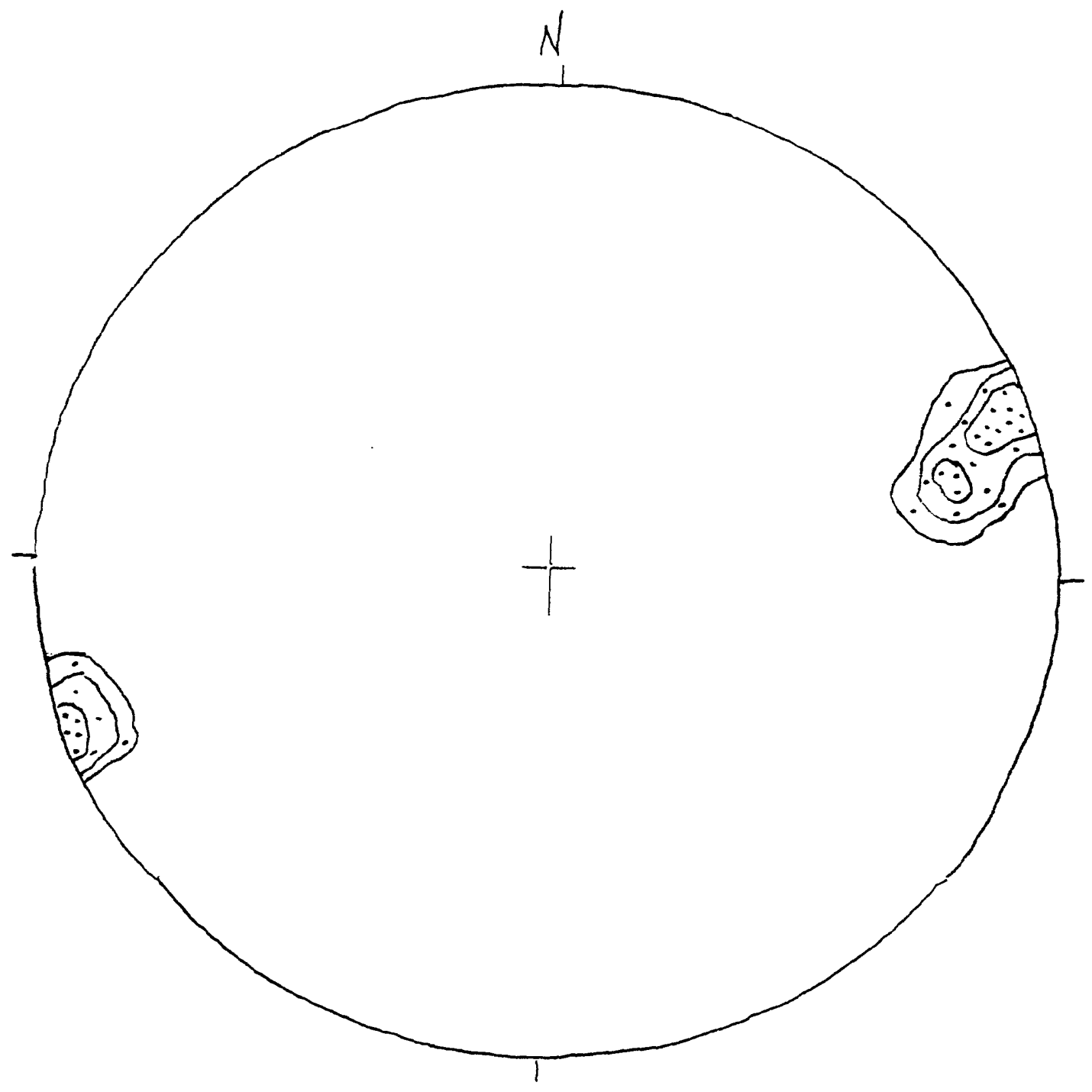

Eigure 32. PI diagram, cleavage, Tiger subarea, Coeur d" Alene district, Idaho. Average pole near $10 \mathrm{~N} 70 \mathrm{E}$, for an average cleavage plane near N2DW 8DSW. $N=25$. Contours at $5,10,15 \%$ per $1 \%$ area. Lower hemisphere, Schmidt equal-area net. 


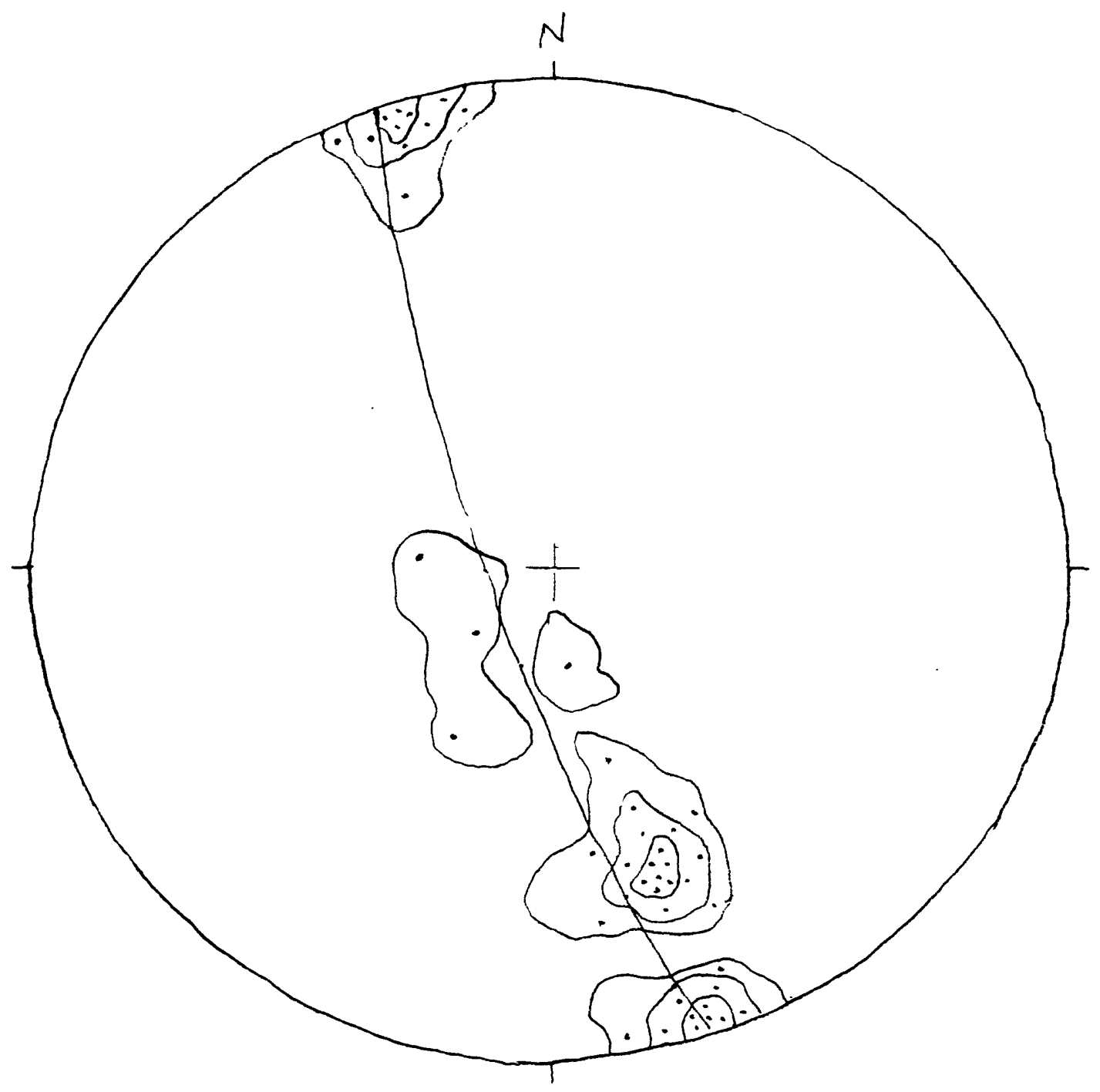

Eigure 33. BETA diagram, cleavage. Tiger subarea, Coeur d Alene district, Idaho. Girdle oriented N2OW $80 \mathrm{SW}$, showing average cleavage shear plane. $N=299$ points from the intersections of 25 planes. Contours at $3.3,6.5$, and $9.8 \%$ per $1 \%$ area. Lower hemisphere, Schmidt equal-area net. 


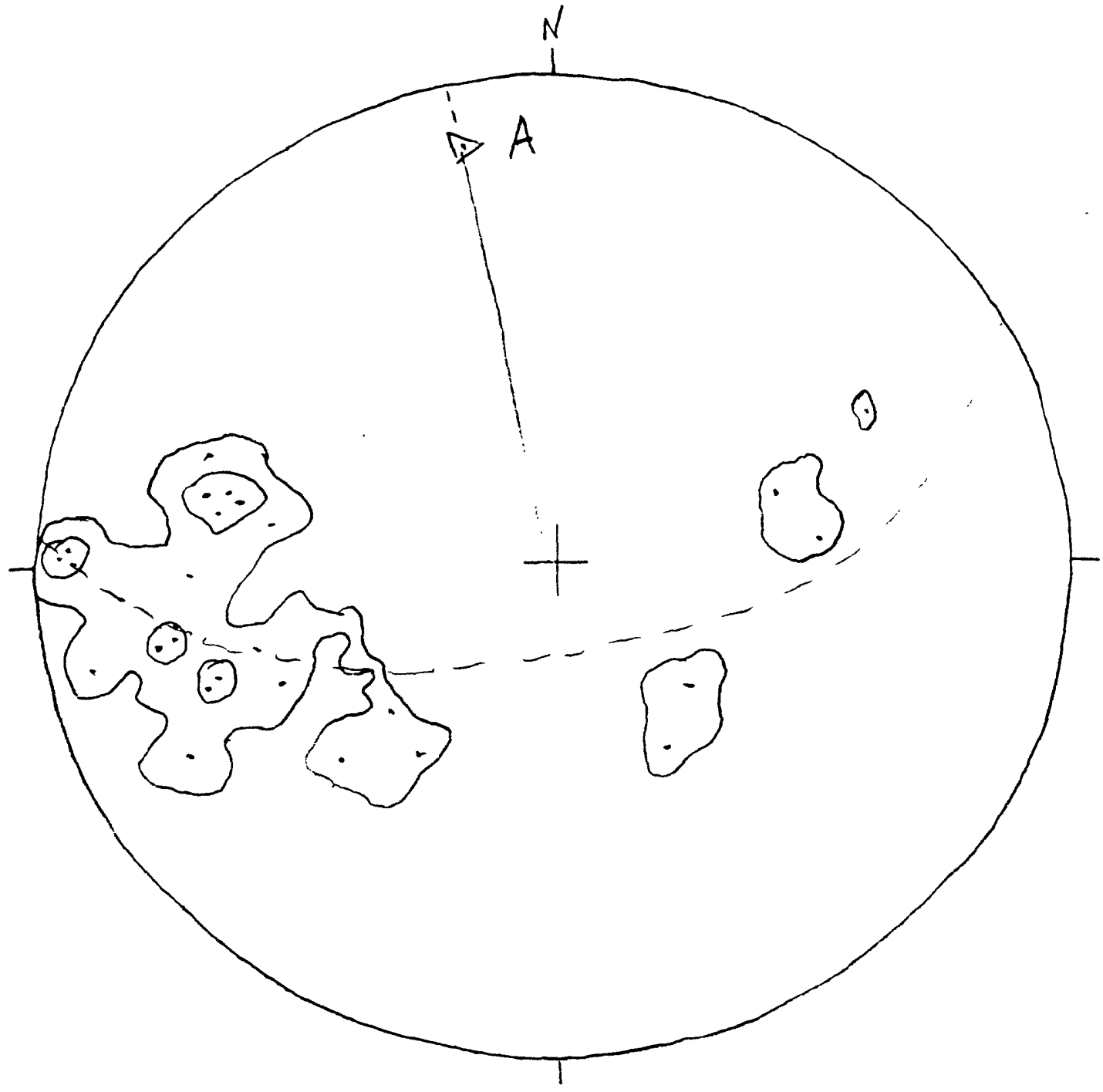

Eigure 34. PI diagram, bedding, Burke subarea, Coeur d' Alene district, Idaho. Contoured point distribution fits best a smal1circle girdle whose axis (A) lies near 15 N12W. Eold limbs average $\mathrm{N} 12 \mathrm{~W}$ 65NE and $\mathrm{N} 15 \mathrm{~W} 45 \mathrm{SW}$. Axial plane $\mathrm{N} 12 \mathrm{~W}$ 80SW. $\mathrm{N}=$ 100. Contours at $3,6 \%$ per $1 \%$ area. Lower hemisphere, Schmidt equal-area ret. 


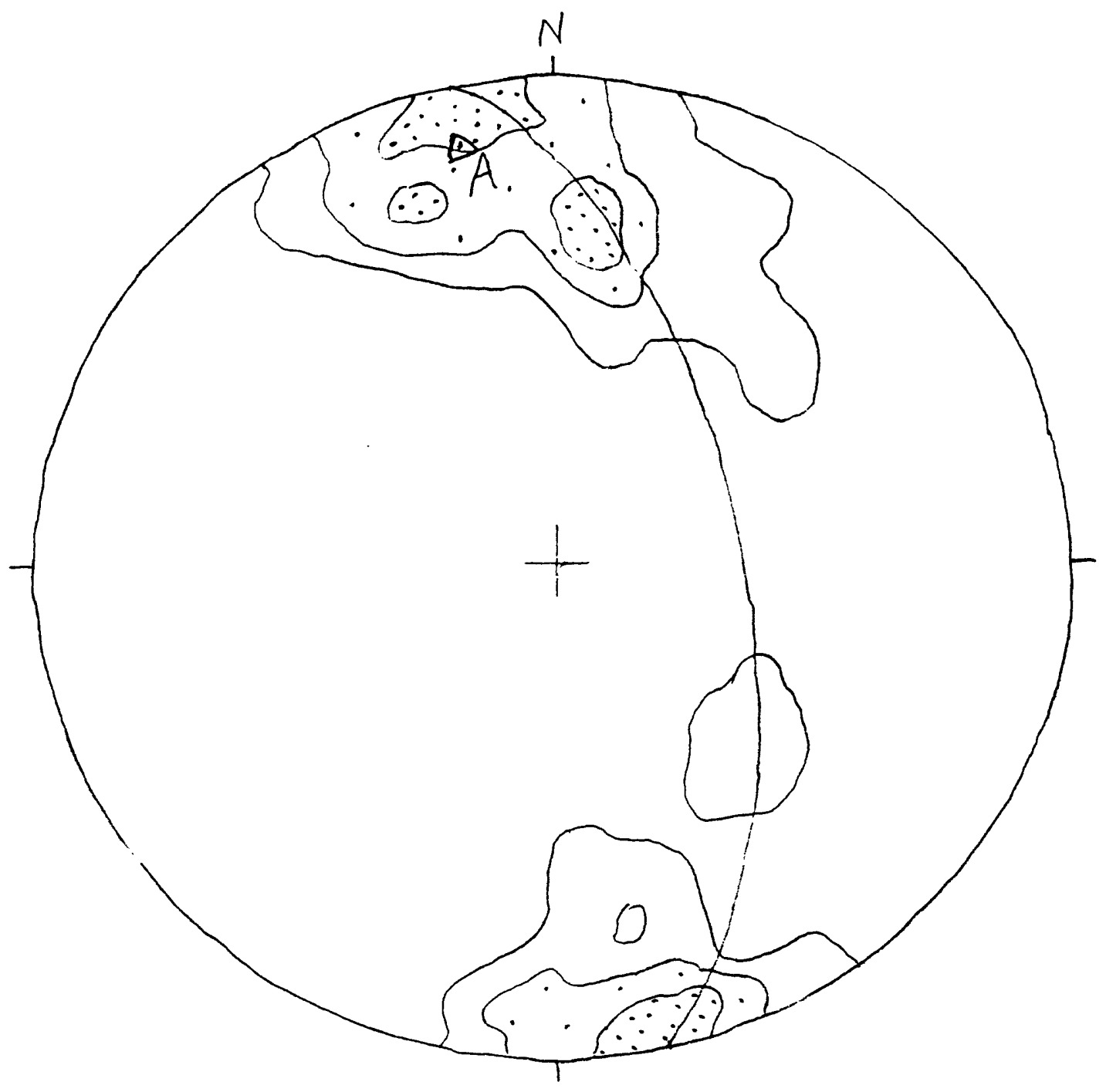

Figure 35. BETA diagram, bedding, Burke subarea, Coeur d Alene district, Idaho. Partial girdle oriented $\mathrm{N} 12 \mathrm{~W} 60 \mathrm{NE}$. Point $\mathrm{A}$ is the axis given in the previous figure. $N=4950$ points from the intersections of 100 planes. Contours at $1.6,3.2$, and $4.8 \%$ per $1 \%$ area. Lower hemisphere, Schmidt equal-area net. 


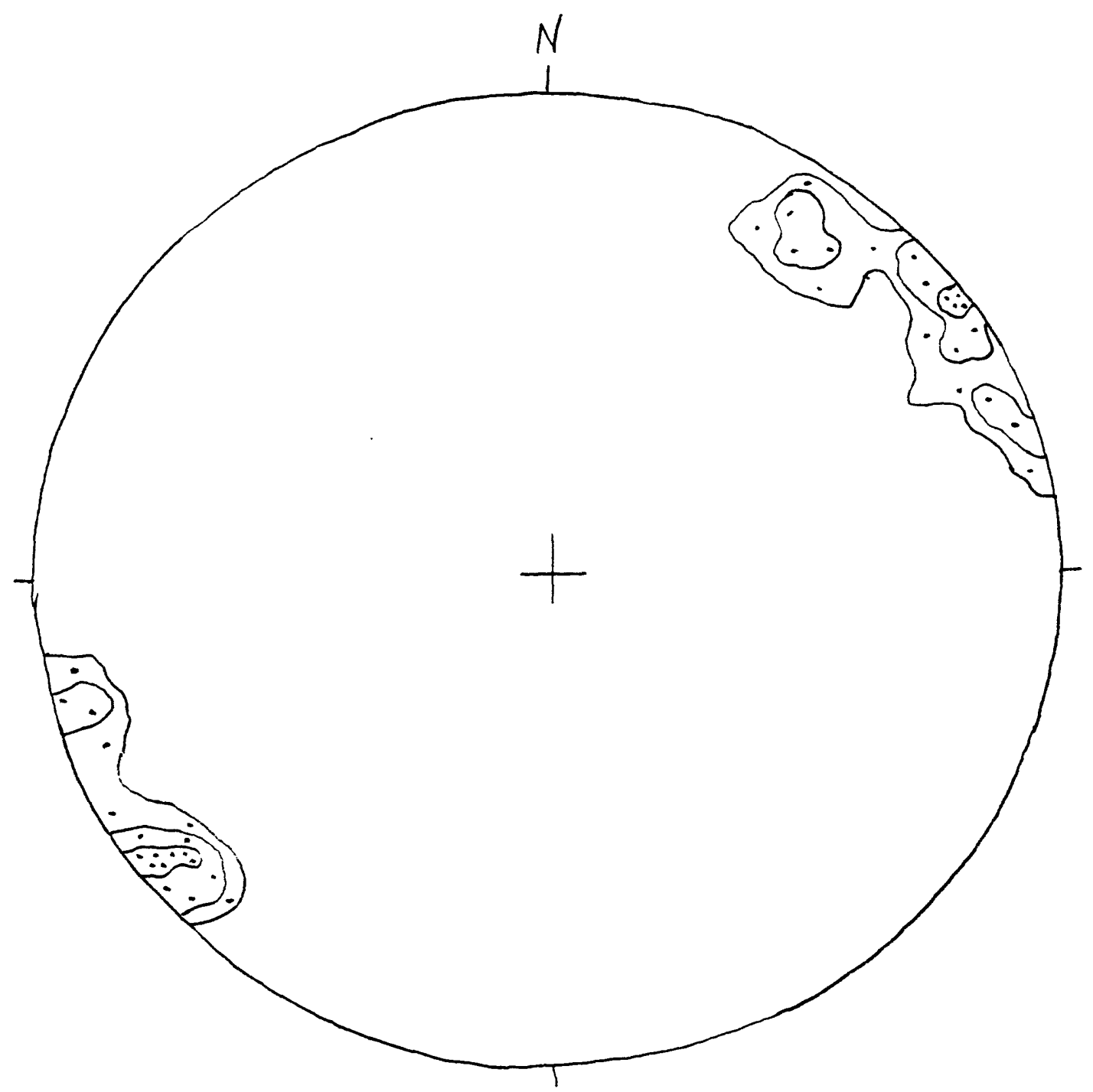

Eigure 36. PI diagram, cleavage, Burke subarea, Coeur d' Alene district, Idaho. Average pole near 05 N55E. $N=60$. Contours at $5,10,15 \%$ per $1 \%$ area. Lower hemisphere, Schmidt equal-area net. 


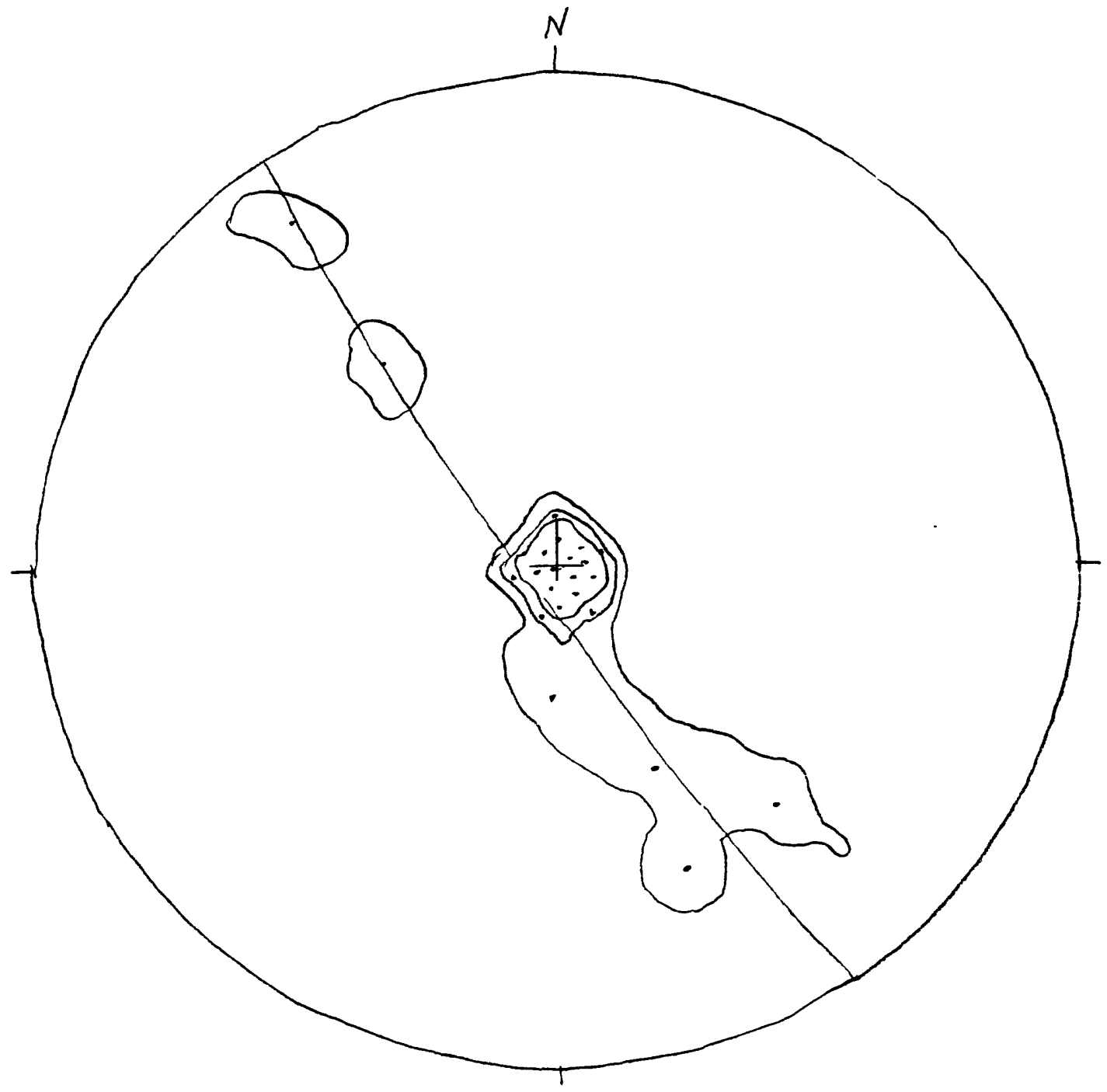

Eigure 37. BETA diagram, cleavage, Burke subarea, Coeur d' Alene district, Idaho. Partial girdle at $N 35 \mathrm{~W} 85 \mathrm{SW}$ defines average cleavage plane. $N=1761$ points from intersections of 60 planes. Contours at $3.5,7.5$, and $10.5 \%$ per $1 \%$ area. Lower hemisphere, Schmidt equal-area net. 
The partial girdle on bedding-plane intersections in the Sunshine subarea (Eig. 17) requires further research. Given that, it suggests a conical fold style, it should serve as a predictor of the axial plane for the folds. The shallow dip of the girdle indicates near-recumbent structures, consistent with the

interpretation by Clough, Section $B^{-} B^{-}$, Plate 2 , 1981, in his Lake Elsie syncline, but clearly at variance with the mildly overturned structures shown by Hobbs and others, 1965, Plate 2 in the East Fork anticline to the north; a similarity exists with features from the Willoughby thesis area mentioned earlier. In general, it appears that structures are of different character in different fault blocks. Data are given in Appendix 3.

The cleavage in the Surshine subarea (Fig. 18) shows a rather diffuse PI pole plot, with principal submaxima at 16 N28E, and $20 \mathrm{~N} 66 \mathrm{E}$; for average shears at $\mathrm{N} 62 \mathrm{~W} 70 \mathrm{SW}$ and N22W $67 \mathrm{SW}$. Given the relatively small data set, it is not clear just what significance may be accorded to these submaxima; but they may represent ductile shear sets similar to those from the Sunshine mine, inasmuch as they intersect in the dip line. The cleavage BETA diagram (Fig. 19) is perhaps more useful than the PI diagram. It shows a girdle at $N 65 \mathrm{~W} 67 \mathrm{SW}$, taken as the average zone of intersections of shears like those seen in the Sunshine mine area. The maximum, an estimate for the $X$ strain axis as elaborated below, lies near the dip line. Thus, the cleavage is independent of fold trend, which is itself a function of varied intensity of rotation toward the Lewis and clark line.

The rotation of early micas seen in oriented thin section is taken as indicating hanging wall up during ductile shear in highangle reverse movements.

Cleavage is shown by a single symbol on the geologic maps (Hobbs and others, 1965), permitting the inference that a single cleavage is present. However, Hobbs and others $(1965, \mathrm{p} .118)$, described two types of ".. foliation or cleavage. . . In large part, the two terms refer to the same features... (a) those that are related to folding, and (b) those that are related to later faulting. Undoubtedly, foliation and cleavage resulting from regional metamorphism has controlled, to some degree, foliation related to later faulting." Eurther, on p. 120, but the two cannot be distinguished in every case. In a few places. the foliation has an orientation counter to what would be expected if the foliation were related to folding."

Somewhat comparable comments were made by Wallace and Hosterman (1956, p. 599), working along the Osburn trend farther east in Montana: "Axial-plane cleavage is useful in the identification of overturned folds, but care had to be exercised not to confuse cleavage related to faulting with axial-plane cleavage."

Subsequent work has not improved on the foregoing observations; every article that deals with cleavage expresses some level of uncertainty.

The cleavage does not fit the Lookout anticline, even in part, comparable to relations at the Big Creek anticline. Axialplane cleavage either did not develop in the anticline or is so weak that it is not expressed in the BETA plot (Eig. 23).

Moreover, axial-plane cleavage in the Lookout anticline would be expected to fan somewhat in dip, but would not fan in 
strike, given the virtually horizontal axis of that cylindrical fold. Thus, a girdle = average shear plane should not emerge in the BETA diagram for the axial-plane part of the cleavage, but rather a strong point maximum horizontal at $\mathrm{N} 75 \mathrm{~W}$ should appear. That maximum is not present.

A more-general question has to do with the possible development of regional cleavage along the whole extent of the Lewis and Clark line. Reconnaissance done by us to the west showe that a complex cleavage visible only in the microscope has developed near the Osburn fault in the vicinity of the city of Coeur d' Alene, Idaho. Thue, cleavage appears to extend along the zone within Idaho and for some distance into Montana.

In some more detailed comparison, we shall begin by comparing wall rock fabrics represented by the sunehine mine area and the Sunshine and Lookout anticline subareas. Bedding relations are given in the PI diagrams in Figures 3, 5, 6, 7, 16 and 20. With axes at $16 \mathrm{~S} 52 \mathrm{E}$ and $00 \mathrm{~N} 75 \mathrm{~W}$, we see varied fold rotation toward the Lewis and Clark line trend. Figure 17 (Sunshine subarea) shows a fairly strong partial girdle, indicating somewhat conical folds. Figures 4 (Sunshine mine) and 21 (Lookout subarea), on the other hand, show both conical and concentric fold sets, respectively. Thus, no systematic fold style is indicated.

Summary cleavage plots from the Sunshine mine are given in Figures 70,74 , and 15. Cleavage data from the Sunshine subarea and the Lookout anticline subarea are given in Figures 19 and 23.

Considering the cleavage slip line parallel to the dip and generated in ductile high-angle reverse movements through a broad shear zone, a somewhat unusual interpretation appears to be indicated. The fact that the cleavage planes generally intersect in or near the dip line of the dominant cleavage, also the slip line, suggests a sort of "flattened" pattern of apparent. constriction flow strain (deformation in a field of uniaxial stress; see Ramsay and Huber, 1983, p. 172; and Reid and others, 1992). The axial mica fabric from microscope study shows deformation in apparent constriction flow also, with its slip line parallel to the dip line.

For a first hypothesis for its development, the cleavage may be regarded as the result of an effective deforming force generated by the normal component of the regional stress acting on the Lewis and Clark line. Cleavage trends lie at small to moderate angles across fold trends, consistent with a transection style of strain developed during rotational uniaxial strain. The apparent shallow-dipping axial plane of folds in the sunshine subarea (Eig. 17) is transected by the steep cleavage, which thus post-dates the folds and their rotation. Moreover, given that the cleavage cuts folds of differing character and trend in several fallt blocks, it appears that some faulting occurred late in fold-rotation time (D2a) but after the generation of the cleavage. As will be seen later, this faulting is early in the N65W trend. Willoughby (1986, p. 66) first raised the possibility of transection: "Where slaty cleavage appears in outcrop with mesoscopic folds, the attitude of the slaty cleavage is not controlled by the small folds. A systematic relationship is not clear, but the possibility of transected folds cannot be 
ruled out."

The transection fabric is clearly late (in places, e.g., it cuts vertically through overturned limbs of folds). Strike and dip variations in cleavage orientation in part may represent the anastomosing fabric characteristic of ductile shear zones. The axis of compression plunges generally at modest angles to the NNE; ductile, high-angle reverse shear is predicted and is borne out in the petrography.

Given the tectonic differences between D2a and D2b, it is also possible that temporal differences exist. Recall that Ransome (1905, p. 285) speculated that deformation occurred at, the time of intrusion of the Idaho batholith. Further work will be necessary to learn how wide and how long a zone is covered by the "regional" cleavage, in what may well be a rather broad zone of distributed ductile shear.

The presence of the transection cleavage at least in Idaho and for some distance in Montana along the Lewis and Clark line suggests that it is generated by regional tectonism within the line. Even so, some more local and independent mechanism might be applicable. We suggest as a second hypothes is that cleavage development may be coextensive with the zone of alteration found by Criss and Fleck (1990), attributed by them to a northern extension of the Idaho batholith, abutting in depth a portion of the Lewis and Clark line. In this case, cleavage development could be related to deep magma emplacement, during which the south side of the Lewis and Clark line moves up. Of course, intraplate tectonism and magmatism may occur synchronously, and this may constitute a third hypothesis. This would be consistent with the suggestion by Criss and Eleck (1990, p. 649-651) of Cretaceous metamorphism and stronger uplift south of the Lewis and Clark line than north of it, associated with Cretaceous magmatism. The high-angle reverse generation of the cleavage (2b) therefore may be of Cretaceous age.

A fourth hypothesis to generate the regional cleavage involves the docking of the Wallowa terrane (Jones and others, 1977; Mortimer, 1986; Miller, 1987; Coney, 1989) somewhere between 87-75 Ma (Criss and Eleck, 1987, p. 122). This terrane pushed eastward more than 80 miles in the later Cretaceous, produced sinistral slip along ite northern margin (the Clearwater axis, 80 miles to the soluth), and slip was more or less easterly past rocks of the North American plate (Anderson, 1991). Existing fractures in the Lewis and Clark line may have been dragged in sympathetic left slip during the Wallow terrane migration. Given the likelihood of obliquity in the regional slip array (N9OE for the Wallowa terrane, N65W for the operative part of the Lewis and Clark line, lateral stresses would be expected to develop, leading to north-directed high-angle reverse movements in the Lewis and Clark line.

None of the foregoing hypotheses can be regarded as "best" at this time, inasmuch as the critical age of ore emplacement, discussed below, remains uncertain. The whole set of movements may be Precambrian or Cretaceous at the present level of knowledge, so all the hypotheses are highly speculative. 
The zone of high strain described above is interpreted as a ductile fault zone and is here named the Terror fault zone (TFZ). Evidence for a zone of early ductile faulting in the district stems from 1968, Gresseth and Reid, p. 41, who showed that folding about a steeply plunging axis in the area of the StarMorning mine at Burke (Eig. 1) is consistent with ductile movements during essentially strike-slip deformation; further evidence comes first from our study of two subareas well mapped by Hobbs and others, Plate 2, 1965, the Rellogg area and the Rose Gulch subarea.

First is comparison of the Rellogg area (about 15 square miles) with the Ross Gulch subarea ( 0.25 square miles), both within the TEZ. Bedding relations are given in Figures 24 and 87. The average fold axis in the bedding for the Kellogg area is 32 N4OW; two fold axes in the Ross Gulch subarea are 54 N68W and $35 \mathrm{~N} 36 \mathrm{~W}$. The $\mathrm{N} 68 \mathrm{~W}$ axis does not appear in the larger area data and may be of only local significance. The general N40W trend with intermediate plunge to the northwest is consistent within the two areas. These axes are established from PI diagrams. The question of concentric v8. conical folds arises here as it does in the wall rocks. The BETA diagrams of Figures 25 and 88 provide the necessary data. Figure 25 (Kellogg area) shows a moderately strong partial girdle at $\mathrm{N} 80 \mathrm{E}$ 35NW with a principal axis at $32 \mathrm{~N} 36 \mathrm{~W}$, near the fold axis established from PI analysis. Eigure 88 (Ross Gulch subarea) on the other hand, shows a moderately strong partial girdle oriented $\mathrm{N} 25 \mathrm{~W} 65 \mathrm{SW}$. The area of high point density is broad, but includes the average axis from prior analysis. Both partial girdles indicate conical fold sets. The axial planes are different, defined by the BETA girdles.

It is unexpected that the two structures are non-coplanar-the cleavage is therefore not of axial-plane type in the larger folds of this domain. They do, however, intersect in an axis oriented $30 \mathrm{~N} 4 \mathrm{OW}$, also close to the general axis from prior analysis. Thus, the conical folds may be arrayed in axial symmetry about that axis, a fabric symmetry consistent with sheath folding (see, e.g., Skjernaa, 1989) and development in apparent constriction flow. The spread of these axial indicators essentially in the axial plane for folded bedding suggests some perhaps moderate sheath fold development during the early folding of the bedding.

The partial BETA girdle from bedding (Figure 25) suggests an approsch to conical fold form, and the girdle provides an estimate of the bedding fold axial plane $=N 80 E$ 30NW. This may be compared to the SNET estimate of the bedding fold axial plane $=\mathrm{N} 82 \mathrm{E} 32 \mathrm{NW}$. The correspondence is excellent.

Figure 27 suggests a conical fold(?) set for the folded cleavage; its girdle provides an estimate of the axial plane(?) for the cleavage folds $=\mathrm{N} 25 \mathrm{E} 37 \mathrm{NW}$. This may be compared to the SNET estimate of the cleavage fold(?) axial plane = N12E 45NW. The fit here is not as good as that for bedding, but the general trends are still reasonably comparable. Field relations show no evidence for folded cleavage, so caution is indicated in the interpretation of this part of the structural geometry. 
The TEZ folds apparently post-date the near-beddingparallel schistosity (S1). For that reason, they are correlated to D2a. The cleavage, somewhat later, is correlated to D2b. The basis for these correlations is discussed further below. Yet, we would emphasize here that the correlation is uncertain at best, due to the general difficulties inherent in correlating events within and without ductile shear zones.

Now it may be regarded as curious that bedding deformed in conical folds shows essentially a single BETA girdle. If folded with the cleavage in the postulated later event and given the several axes implicit in Eigure 27 , the bedding PI should show crossed girdles; but does not.

Analysis of Figure 93 gives insight into details of the TEZ. Two partial girdles on the bedding (Eig. 87) suggest two fold sets and thus cross-folding (but note that a single, small-circle girdle may be present instead). The two axes are shown in Eigure 93 , axes 1 ( $54 \mathrm{~N} 68 \mathrm{~W})$ and 2 ( $35 \mathrm{~N} 36 \mathrm{~W})$. The principal BETA girdle (Eig. 88) from bedding (plane 3, Fig. 93) lies at an angle of about $10^{\circ}$ to the average bedding plane (Eig. 93, plane 4), suggesting the possibility of tight folding. One near-isoclinal fold with axial-plane cleavage was seen in the outcrops. The BETA girdle (plane 3) provides an estimate of the axial plane of the fold set generated during folding of the beds. Planes 3 and 4 intersect in the girdle-estimated fold axis ( $54 \mathrm{~N} 68 \mathrm{~W}$ ).

The BETA diagram from Figure 88 contains elements also indicative of cross folding (plane 3 in Eig. 93). Three weak cross girdles are present: planes $B, C$, and $D$ in Figure 88 , labeled 5, 6, and 7, respectively, in Eigure 93 Each of these, like plane 3 in Eigure 93, represents the axial plane orientation of a cross-fold set; relative intensities suggest that planes 5, 6 , and 7 represent relatively weak fold sets.

The strong girdle of Plane 3 seen in Figures 88 and 93 typifies conical fold arrays. Therefore, the bedding is deformed in conical folds. Further, the axial plane for folded bedding is near-recumbent (Eigs. 25 and 29). Finally, the weak cross fold sets are also of conical character.

The relation of cleavage to the folds is considered next. Cleavage symmetry is shown in the PI diagrams of Eigures 26 (Kellogg area) and 89 (Ross Gulch subarea). Figure 26 shows a strong $\mathrm{PI}$ girdle with axis at $36 \mathrm{~N} 4 \mathrm{OW}$, roughly the same axis as that for folding in the bedding. Eigure 89, on the other hand, shows a PI girdle of moderate strength about an axis oriented 50 N90W. This is close to the secondary PI girdle of Figure 87 for bedding in the Ross Gulch subarea. Thus, it appears possible that a local difference exists in timing of cleavage development.

The PI girdles on cleavage are, however, uniform in that they show an axial symmetry of the cleavage. That symmetry may develop in either of two ways: (a) folding of the cleavage subsequent to its development, with slip perpendicular to the fold axis trend, or (b) generation of the cleavage during axially symmetric flow of apparent constriction flow type, with slip in the direction of the axis of symmetry. Crossed PI girdles from bedding at the Ross Gulch subarea (Eig. 87) would be consistent, with the first possibility; suggesting that cleavage was locally folded after it formed, and the bedding was refolded with it. 
Some scattered point concentrations in the PI diagram for Kellogg-area bedding ( $E$ ig. 24) may reflect the same deformation and yet show that it was weak and subordinate. Refolding is not supported by the bedding details, however (see Fig. 29). The "crossed girdles" of Eigure 87 more likely represent a single, small-circle girdle.

Conventional cleavage is generally axial planar to the folds with which it is associated. The PI partial girdle on cleavage from Figure 89 suggests that cleavage has been folded during or after its development. The principal or strongest axis of that apparent folding ( $50 \mathrm{~N} 88 \mathrm{~W}$, expressed as the girdle pole) is well off axes of fold sets expressed in the bedding. It is possible in Eigure 89 that selection of a large-circle girdle is incorrect. A diffuse, small-circle girdle is at least within the realm of possibility. It is notable that two strong maxima lie in the chosen great-circle girdle, showing two cleavage "sets": NO4W 50SW and N48E 6ONW. These are plotted as planes 11 and 12 , respectively, in Eigure 9.3. Plane 11 is the stronger one and is a possible candidate for axial-plane cleavage. In that case, it should coincide with plane 3 of Figure 93 , the axial plane identified for a principal fold set. It clearly does not; therefore, the cleavage is not of axial planar type. The second cleavage, of northeast trend, is far off any bedding elements.

Further geometry of the cleavage is given in Eigure 90 , a BETA diagram; a strong BETA girdle exists, suggesting that the cleavage is also deformed in conical folds. This girdle is coincident with plane 11 in Eigure 93 , a major cleavage orientation from Figure 89 . The axis of principal cleavage folding, the girdle pole, is oriented $50 \mathrm{NBOW}$, axis 10 in Eigure 33, which is also defined by the intersection of the two strongest cleavage trends (planes 11 and 12 in Fig. 93). Secondary cleavage fold axis directions are $30 \mathrm{~S} 23 \mathrm{~W}$ and $30 \mathrm{~N} 35 \mathrm{~W}$, given as axes 13 and 14 in Eigure 93 .

Now, it is necessary to see how various linear elements compare to the several indicated axial plane sets. Two principal kinds of linear elements are present: hinges and rods from Figure 91 (labeled line 8 in Eigure 95 ), and bedding-cleavage intersections from Eigure 92 (labeled line 9 in Eig. 93). Taking the maximum for hinges and rods ( $46 \mathrm{~N} 56 \mathrm{~W}$ ), it clearly does not, relate to the BETA girdle from bedding, as it is well off the intersection of that girdle with bedding (line 1, 54 N68W). Thus the minor folds and rods relate to a different folding event than that which produced the girdle A of Eigure 87 . Neither does it, relate to the axis defined as the pole to girdle $B$ of Eigure 87 (axis 2 in Eig. 93: $35 \mathrm{~N} 36 \mathrm{~W}$ ). Thus, at least three fold phases are suggested in bedding-derived data. A fourth axis is indicated by the principal fold axis in the cleavage, traces of which do not appear in the bedding diagrams, and fifth and sixth ones by axes 13 and 14 (Eig. 93). Willoughby (1986), working a bit farther north, found three fold sets in poorly exposed terrane still within the TEZ.

The fabric is markedly triclinic. The axes 2 and 14 in Eigure 93 are coincident. Thus, bedding deformation in part is shown in association with some cleavage development. Mostly, though, the cleavage shows clearly a transection relation to 
bedding fold features and is thus later than those features.

The plot for bedding-cleavage intersections (Eig. 92 and plane 9 in Fig. 93) is discordant to the average bedding-cleavage orientations (planes 4 and 11 and planes 4 and 12 in Figure 93). Figure 92 shows that bedding-cleavage intersection axes are dispersed in a partial girdle. This is consistent with the BETA girdles seen both for bedding and for cleavage. Such dispersion of fold elements along the axial planes may be interpreted as diue to the effects of sheath folding. One single sheath event, with folding early and cleavage later, with slip rotation of various linear elements toward the slip line during intense apparent constriction flow, may explain the features better than the multiple fold event-set that emerges from the alternative analysis given above. Another alternative, perhaps best, is that, early NOOW folds were dragged into the TEZ and partly overprinted by or reorganized into or toward sheath fold forms and cleavage developed during ductile faulting.

Petrography bears on the mechanics of cleavage development. An oriented specimen from the Ross Gulch subarea shows a crude microrodding which defines a stretching lineation generally plunging toward the WNW, suggesting a slip line in that direction, and consistent with the axial symmetry from structural analysis. Thus, cleavage development in the TEZ occurred in the second way outlined above; namely, in apparent constriction flow, independent of fold forms although broadly coaxial with them. The Deadman shear zone (Eig. 1) (Hobbs and others, 1965, p. 10911) appears to have axially symmetric cleavage and may well represent a higher-strain portion of the TEZ; in any case, it lies within the projected TEZ.

Apparent constriction flow in oblique slip of ductile type is indicated in the TEZ, but the data in hand do not allow further interpretation as to right or left slip (of course, as noted elsewhere in this paper, regional fold deflections suggest generally sinistral movements during $\mathrm{D} 2 \mathrm{a}$, and those movements may have extended into $\mathrm{D} 2 \mathrm{~b}$ ).

Cleavage BETA diagrams give further information about the cleavage. Figure 27 (Kellogg area) shows a strong girdle oriented N25E $40 \mathrm{NW}$, with a major axis at $36 \mathrm{~N} 37 \mathrm{~W}$, close to the general strain axis discerned above. Figure 90 (Ross Gulch subarea) shows a comparable girdle, but oriented NOOW and with its major axis oriented 50 N90W. The girdle in Figure 90 euggests conical folding on the cleavage, in a sheath array, reorganizing cleavage perhaps developed during earlier sheath activity. Thus, the flow vector may have changed late from NW to $W$ in a minor and local way.

Bedding-cleavage intersections provide a final way for comparison. Figures 28 (Kellogg area) and 92 (Ross Gulch eubarea) show various trends generally to the northwest, consistent with the axial symmetry deduced earlier. The diagrammatic interpretation shown in Figure 29 requires a shallow-dipping (true tectonic dip) axial plane and later offset of limbs along a transcurrent fault probably of Laramide age.

Seemingly incongmous minor folds in limb $B$ turn out, to be congruous rather than incongruous as initially seemed to be the case, a better interpretation given that their style and 
orientation are like those of the minor folds in limb A. The cleavage, of varied dips and seemingly axial planar in some of the minor folds, must post-date the folding in some measure.

The zone studied here is one of much higher strain than

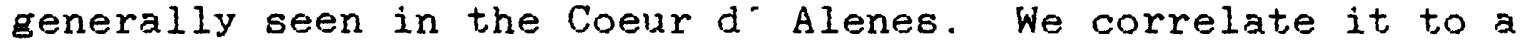
comparable zone at the Star-Morning mine, mentioned above.

What is suggested is a zone of high-intensity ductile strain taken as a portion of the TFZ. The $40^{\circ}-55^{\circ}$-plunging interpreted slip line indicates an oblique-slip array.

From subarea comparisons above involving TEZ trend analysis, it appears that the structural geometry of bedding in the Moon Creek subarea resembles that of wall rocks to the north both in PI and in BETA; and that the structural geometry of cleavage resembles that of the TEZ, differing markedly from that of cleavage in wall rocks to the south. In general, it appears that the Moon Creek subarea lies within the TEZ, and that the Terror Gulch subarea 1 ies in wall rocks to the south. Cleavage in the Terror Gulch subarea resembles area wall-rock cleavage generally, in a transection relation to earlier folds and developed during ductile thrusting, and a WNW trend is supported for the TEZ. Therefore, the Terror Gulch subarea rocks lie south of the TEZ.

As mentioned above, trend analysis for the TFZ contains uncertainty because it is cut both by the Carpenter Gulch thrust and the Dobson Pass fault (Fig. 1), a low-angle normal fault (Hobbs and others, 1965, p. 84). We note that normal slip in the Dobson Pass, which strikes across the TEZ, would produce little TEZ offset. During reconnaissance examination of the Carpenter Gulch thrust, we measured a few mesoscale, brittle shears and related extension fractures interpreted as a part of the thrust movement. A movement solution from these data yields a slip line near parallel to the trace of the Osburn fault. Here also, little TFZ offset would be expected. Both faults are probably of Laramide age, generated during local movements in the walls of the Osburn fault.

Data from the Tiger (north of the TEZ) and Burke (within the TFZ) subareas described above suggest first a N7OW trend for the TFZ and second a history involving folding, cleavage development, and sinistral rotation. Both subareas are in rocks of the Burke Formation, competent quartzite likely to yield less during deformation than the "soft" argillite of the Prichard Eormation. This does seem to happen; moreover, the styles and to some extent the trends are different as well, compared to those in the Prichard rocks.

Considering the transition from the Tiger subarea to the Burke subarea, the folds show a $12^{\circ}$ swing to the northwest, consistent with sinistral rotation. Folds cylindrical in the Tiger subarea become conical as they experience the $12^{\circ}$ rotation, consistent with overprinted deformation about a new strain axis; this represents a similarity to the TEZ farther west, where folds within it are also conical (Figs. 88 and 93).

Cleavage trends about $20^{\circ}$ more westerly than folds in both subareas. The first point is that the cleavage bears a transection relation to the folds, as has also been seen in areas south of the Osburn fault, described above. The second point is that cleavage appears to pre-date fold rotation here or is 
perhaps synchronous with it, whereas it appears to post-date such rotation south of the Osburn fault or is perhaps synchronous with or late in it.

Considering the different fold trends within the TEZ (N4OW near Kellogg and $N 12 W$ near Burke), and their angular relations to the postulated N7OW trend of that zone, we speculate that differential rotation has occurred during ductile sinistral slip. Original trends are in NOOW in the wall rocks north of the TEZ in both areas, and the deflections are from NDOW. Rotation was stronger in the Prichard rocks and weaker in the Burke. Their different competencies have been mentioned above. This hypothesis accounts in yet another way for different internal fold trends within the Kellogg fault zone.

Campbell (1960) and Wallace and Hosterman (1956, p. 599-601) noted a zone of intensely foliated rocks a few miles wide in the north wall of the Osburn fault farther east in Montana; their work was mentioned by Hobbs and others, 1965, p. 120. This may well correlate to the TEZ. If that is so, then the TEZ and Dsburn fault are generally parallel; further, the Osburn may represent a late, brittle break along and near the southern margin of the TEZ.

The character of the TEZ cleavage, similar in its microscopic sericite to the regional $\mathrm{S2}$ cleavage to the south, suggests that the two are broadly coeval. This is explored in some depth in the later text. Thus, both ductile high-angle reverse movements in the walls of the TEZ and oblique ductile slip in the TEZ are correlated broadly to D2b.

As above, from Criss and Fleck (1990, p. 649-651), the ductile movements may be of Cretaceous age. Transcurrent intraplate movements would drive the TEZ, and deep magma emplacement would drive the southern block upward; perhaps they need not be precisely synchronous. The fourth hypothesis on the regional cleavage contains material applicable here. Late Cretaceous, differential movement of the Wallowa terrane would move Lewis and Clark line elements in sinistral slip. Therefore, the Terror fault zone may have developed during sinistral slip. Because of the similar mineralogy in the rocks, both deformations appear to belong to the same thermal event. However, a comment from earlier needs emphasis here: if the events are all Precambrian, different tectonic scenarios must be sought.

\section{Regional-TEZ Cleavage Correlation}

Comparing regional cleavage to cleavage within the TEZ, it is seen that marked differences exist, particularly in the existence of dominantly planar cleavage in the wall rocks compared to axially symmetric cleavage of the Prichard in the TEZ rocks. Ductile, high-angle reverse movements in the walls may in part post-date oblique slip in the TEZ, and may be responsible for rare folded cleavage in the TEZ. Similarity in the mineralogy and microscopic fabrics in the two cleavages, as remarked earlier, suggests the same $\mathrm{P}-\mathrm{T}$ interval and thus development in the same thermal event. 
If timing and mechanics for wall-rock cleavage development are the same across the district, then high-angle reverse slip reactivation, south side up, will have been operative in the Tiger subarea and neighboring wall-rock areas. It should be noted that, given the northwesterly plunge of structures in the TEZ in the Kellogg area combined with proposed sinistral slip, south side up is predicted as well. Of course, this requires checking the Burke area cleavage slip lines with appropriate petrography. In any case, the substantially different regional cleavage trends ( $N 65 \mathrm{~W}$ vs $N 35 \mathrm{~W}$ ) will remain to be evaluated, as will the fact that cleavage in the southern areas crosses fold trends "both ways".

A further point also needs consideration. In the subareas south of the Osburn fault, cleavage and vein-controlling faults are sufficiently close in trend that the faults could be hypothesized to owe their orientation to reactivation of cleavage fractures and to be partly controlled by strain-softening processes. In the Tiger and Burke subareas (Eryklund, 1964), vein fractures and some faults have the same general orientation, N65W, as those farther west, and cut across the cleavage. This opens the possibility that cleavage development and vein-fracture development are independent events across the district, and only accidentally sub-parallel in places. Therefore, cleavage would be independent, related neither to folding nor to faulting.

Remaining for consideration is an hypothesis of unifying character, one that accounts in a single mechanical way for both cleavage sets to be developed synchronously. We note that the Wallowa terrane docking event occurred between about 87-75 Ma, based on syntectonic intrusions in the suture zone (Criss and Fleck, 1987 , p. 122). Existing fractures in the Lewis and Clark line may have been dragged in sympathetic left slip as the Wallowa terrane pushed eastward past North American plate rocks differentially in left slip perhaps as much as $80 \mathrm{mi}$ along the Clearwater axis, located about $80 \mathrm{mi}$ south of Coeur d' Alene. This if the locus of the east-trending segment of the 0.706 ${ }^{87} \mathrm{Sr} /{ }^{86} \mathrm{Sr}$ line in northwestern North America (Armstrong and others, 1977). The estimate of offset is crude, based on extrapolation of trend lines of related rocks in NE Washington and western Idaho, but broadly consistent with $\mathrm{Sr}$ data presented by Fleck and Gunn (1991). The slip line trended easterly, based on relict high-T mylonite, east-trending stretching lineation, possible sheath folds nearly parallel to that lineation, and quartz c-axis fabric (showing left slip) in crystalline rocks just north of the Clearwater axis (Anderson, 1991) and may have remained fairly constant on that trend during the docking event. Farther east in this zone, Strayer and others, 1989, studied a 1.5-km-thick mylonite in the zone where the suture turns south. They found mylonitic foliation at one place in the bend to average N64W 54NE, with a dip-line mylonitic lineation. Strain is high, shown in part by rotation of fold hinges into near parallelism with the slip line, producing sheath-fold geometries. Slip is tops-to-southwest, consistent with left slip in the $E-W$ segment of the suture. From shear-strain analysis, they estimate displacement as likely more than $80 \mathrm{~km}$. Sympathetic slip in the Lewis and Clark line is postulated to parallel its ESE trend; 
slip in the line therefore may have been of fairly constant trend as well. The wedging effect implicit in this tectonic array will cause synchronous strike-slip and thrusting movements in a snowplow-like effect perhaps better characterized as a sort of intraplate transpression mechanics.

\title{
ERACTURE DEVELOPMENT
}

\author{
Mineralized Early Eaults (Class B) and Veins
}

General

Hobbs and others (1965, p. 71) recognized several ages of faulting, which they characterized in the following classes: (a) low-angle reverse faults, (b) early, steep-dipping reverse and normal faults, (c) strike-slip and related normal faults, and (d) late normal faults; and pointed out that reactivation of some faults, perhape with reversal or change of the orientation of net slip, is probable. They suggested that the main stage of mineralization probably succeeded the formation of low-angle faults as well as some of the steep reverse and normal faults and was probably related to the early phases of strike-silp deformation. Class (b) faults of the Hobbs and others. categories are considered in this section, regarded as developed during $\mathrm{D} 2 \mathrm{c}$.

Early faults (class b), some vein-bearing, cut folds and

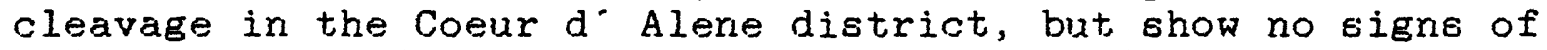
deformation in folding (Hobbs and othere, 1965, p. 113). This same relation is seen in the array of mineral belts (defined by vein clusters), which cut straight acrose folde (Eryklund, 1964, p. 7) and in places cleavage of diverse orientations; on a constant, near-N65W, trend. Eryklund noted further, at p. 7 , that the ". . origin of the fracture systems of the mineral belts should not be ascribed, therefore, to joint systems produced in. . folding.

The restored diagram of the Coeur d' Alene district given by Bennett and Venkatakrishnan (1982, Eig. 2) suggests that the fault movements during mineralization were not very extensive. The target-shaped pattern produced by that restoration is of great interest and will be discussed further below.

Mineralized faults and veins have been cut, offset, and reactivated in later faulting. At least four evente have been involved, requiring that falult and vein analysis consider questions of slip line orientations at least (a) during mineralization and (b) during post-mineral movement. Slip lines during veining are particularly interesting as having potential exploration significance; little work appears to have been done on this topic.

Some faults in the northeastern Coeur $d^{*}$ Alene district trend parallel to local N25W 90 cleavage (Campo, 1984, p. 125). Campo regarded the flow cleavage as a ductile response to faulting; however, it may well be the other way around: strainsoftened rock may yield preferentially in younger, brittle faulting, and he said as much on $p .127$. The Laramide Osburn now becomes a late, brittle fault, cutting and partly reactivating 
some earlier trends. The Osburn fault zone may not have existed at the time of mineralization, and there may not have been a precursor faldt where it is now, given that, it appears to lie near the southern margin of the earlier TEZ. However, as shown above, strong movements occurred in the $N 55 \mathrm{~W}$ set of faults in postcleavage and possibly pre-mineral time. A set of 58 of these faults from Hobbs and others, 1965, text and plates, shows anastomosing patterns, intersections in the dip line, both reverse and normal movements in places, and axial symmetry as well as slicks near the dip line. The diagram is not shown here, as it is closely comparable to that of the vein patterns shown in Figure 38 and is therefore well represented by it.

Variations in cleavage orientation among Sunshine mine domains suggest faulting offset, along the bounding faults of Class (b) age (Eig. 2) after cleavage development. This is supported further by still different cleavage attitudes in the Sunshine subarea (Figs. 9,11, 15, and 19). Different folding styles and trends among the fault blocks (Figs. 4 and 17, e.g.) support this concept. An important question is on the silip line orientation for this post-cleavage faulting, which may yet predate movements during mineralization. Until factual evidence emerges, we shall assume that, being apparently late in D2b, the bounding faults developed both during high-angle reverse and normal movements.

The question on the early fault/vein movement, then, is one of renewed movement principally in the Class (b) set during its development and subsequent mineralization; apparently in postcleavage time, so far as present evidence goes. Such faults as the Silver Syndicate, Polaris, and Big Creek (Eigs. 1 and 2), important in the Silver Belt, (Eig. 1), are part of the that set; the Alhambra, parallel to the other two mentioned, contains some mineralized veins (Hobbs and others, 1965, p. 91). Such faults seen in the Sunshine mine show coherent, schistose shear zones indicative of ductile yielding. Gouge and clay are seen only in the uncommon situation where reactivation in younger movements (with horizontal slickenlines) has occurred.

Sunshine Mine Data

The Sunshine mine, taken as a representative subarea, provides detailed data for a convenient beginning point in the consideration of veins, taken as developed during D2d. General features are described first. Siderite veins contain ore shoots filled with tetrahedrite. Most ore shoots plunge steeply southwest, near the dip line. Some ore shoots rake horizontally and others at intermediate angles to the southeast, but even those contain subshoots of steep soluthwesterly plunge. Some veins, mineralized in the "steeps" were filled during normal slip along the fractures; most, mineralized in the "flats" were filled during reverse slip along the fractures. Domain-bounding faults of Class b (Eig. 2) show an average trend of N66W 615W. It, is notable that the veins within the several domains show no strong relation to bounding fault trends, yet those faults are in part mineralized. 
The veins in the Sunshine mine (see Fig. 1) are taken as representative for a mine subarea analysis typical for at least half of the district (see also the discussion below on mineral belts). Ore shoots plunge steeply to the southwest for the most part, as is typical district-wide (cf. Fryklund, 1964), and seen on mine long-sections from across the district. A set of 217 vein attitudes from 57 veins $(N=1-14)$ was compiled for study (Appendix 4 and Fig. 38). Dips are fairly uniform and steep to the south, but strikes trend over most of the compass; the strongest trend, however, is near N9OE, different from fault, bedding, or cleavage trende. Trend values are fairly symmetrically distributed about the N9OE direction. Shown on Figure 39 , the veins average to intersect in a common line oriented 64 S10W; thus, the line of vein intersection has a steep southwesterly plunge in most veins, parallel to the general ore shoot rake. Slickenlines and grooves on the veins and in ore shoots also plunge steeply to the southwest, parallel to the line of vein intersection. Shear steps on the vein-fracture surfaces generally show hanging wall up, although shear steps for hanging wall down are seen in places.

The slickenlines on the cleavage near veins are annealed, generated under higher temperatures. From oriented thin sections cut parallel to the slickenlines, it is seen that the shear walls are loci of thin mylonite selvages. Shear steps on the walls, seen both underground and in thin section show hanging wall up, as does $S-C$ fabric in the mylonite. Micro-rodding occurs in the mylonite, involving both quartz and siderite; siderite is a principal gangue in the veins, involved with mylonite in some measure.

Veins have been mined through vertical intervals ranging from about 300 ft to 2100 ft (Appendix 4). Vein attitudes range from relatively constant (Eigs. 40 and 41 ), to somewhat varied (Fig. 42) to strongly varied ( $\mathrm{Fig}$. 43), but regardless of trend diversity, vein continuity through the range of diversity has been shown by mining.

The primary vein material is siderite; relict crustification fabric is present, shown partly by siderite in elongate grains normal to vein walls and partly by banded vein fabric parallel to vein walls. Some veins split or branch; at branching pointe, siderite vein material remains continuous and uniform through the area of the split. Such vein splits intersect, in lines generally plunging steeply to the southwest, parallel to the mine average vein intersection (see Fig. 39).

Tetrahedrite ore shoots occur sporadically in the veins and are generally elongate with steep plunges to the southwest; spacing along the veins is irregular and independent of vein fracture intersections. Tetrahedrite shoots are filled with more or less of tabular to irregular siderite fragments, and the fabric has rather a chaotic aspect. Tabular fragments are cut by numerous cross fractures oriented at high angles to vein walls and filled with tetrahedrite.

Minor pinch-and-swell features are shown by veins, with axes both in the dip line and in the strike line. These constitute a form of boudinage, due to late-stage flattening of the veins. 


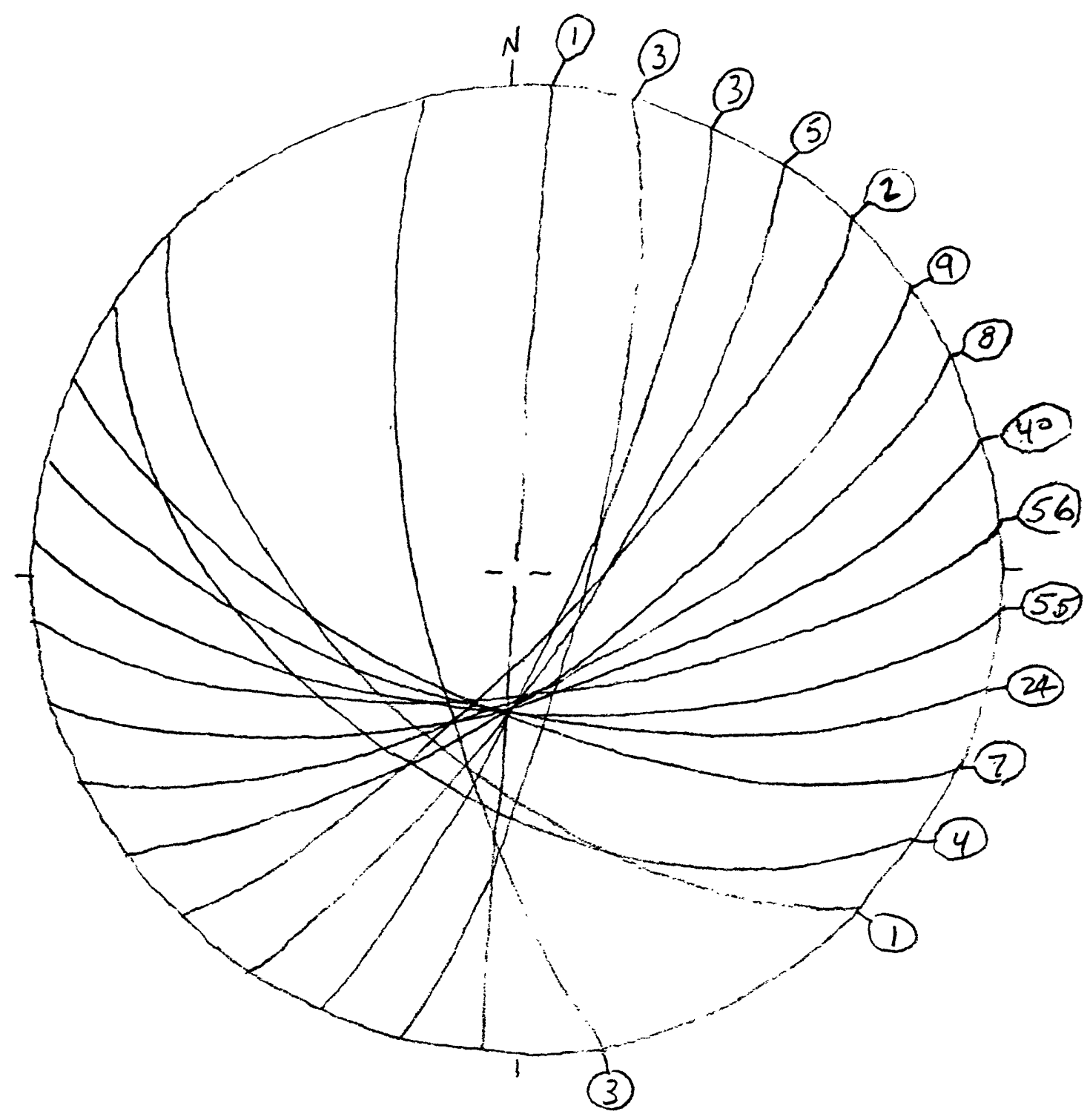

Eigure 38. Average Sunshine veins in fifteen $10^{\circ}$ intervals. $N=217$. Circled numbers show frequency in each interval. Wulff net, lower hemisphere. 


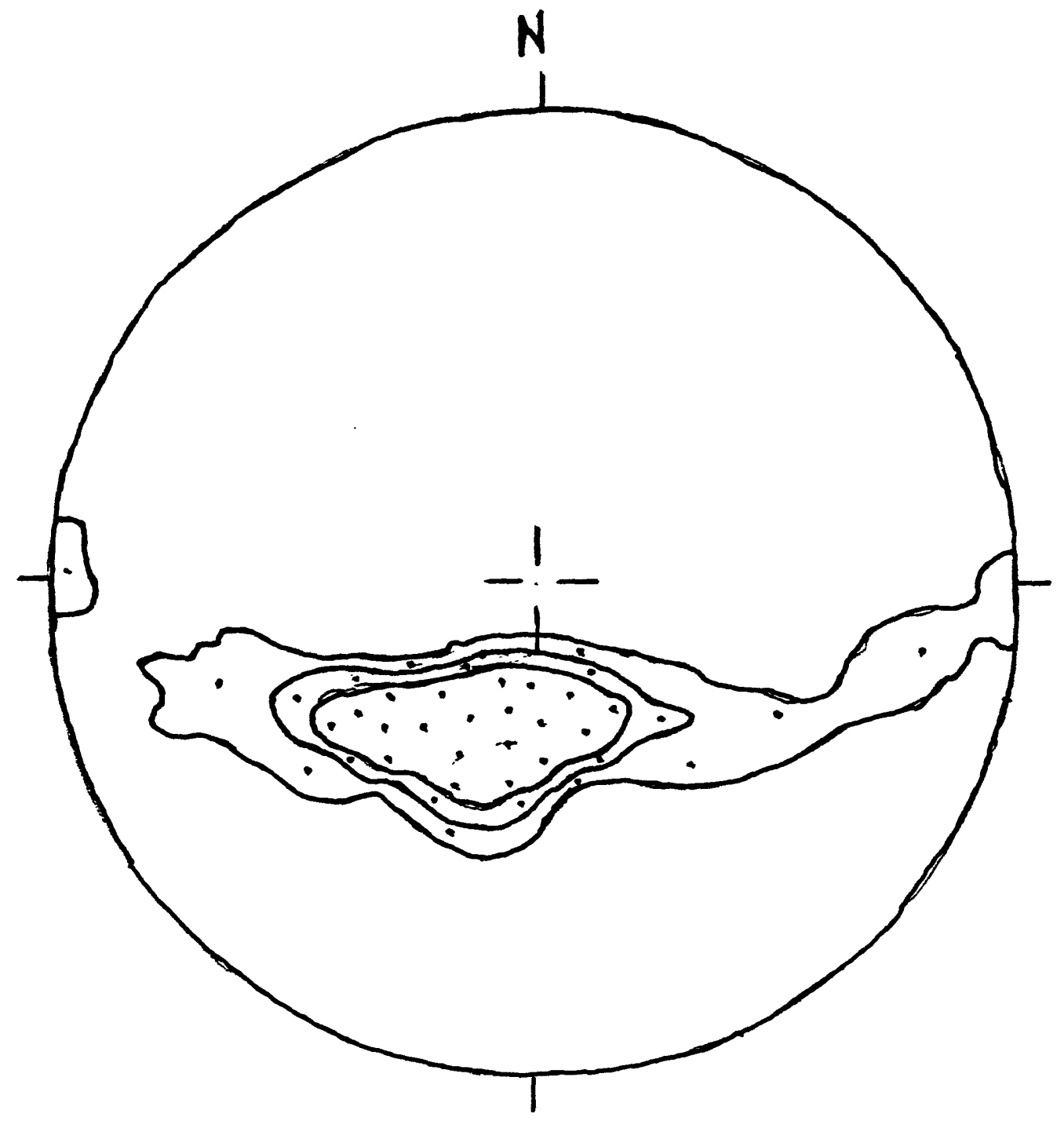

Figure 39. BETA diagram. Fifty seven veins representing a set of 217. $\mathrm{N}=1,595$. Beta axis $=64519 \mathrm{~W}$, raking $80^{\circ} \mathrm{W}$ in the average vein; the beta axis = the average vein intersection, paralleled by average ore shoot axes. Contours at 2,4 , $6 \%$ per $1 \%$ area. Schmidt net, lower hemisphere. 


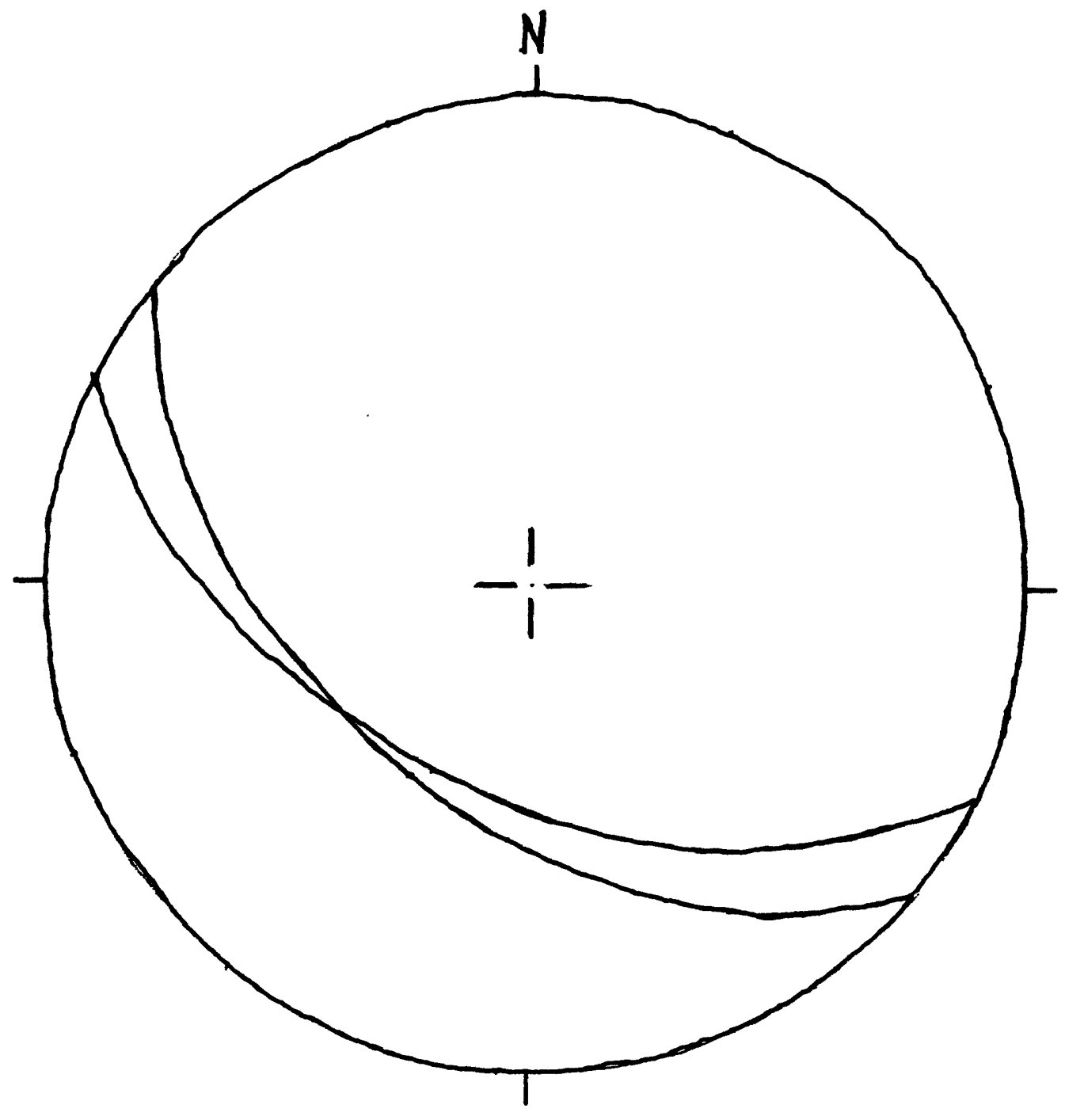

Figure 40. Simple array, typical NW veins (RO3-ROI Link vein), mined through 300 ft vertically. Schmidt net, lower hemisphere.

$35 c$ 


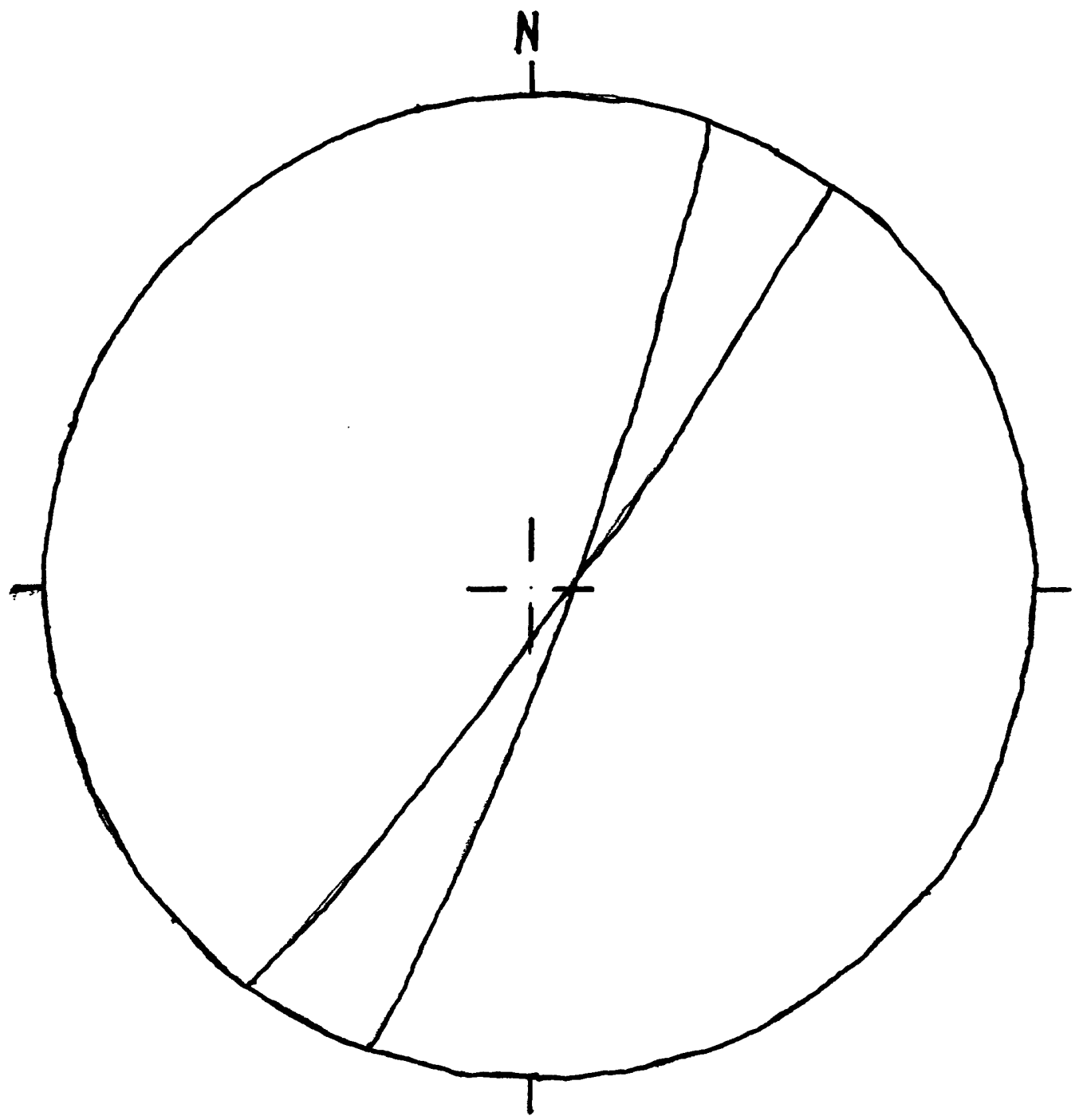

Figure 41. Simple array, northeast veins. RO3 vein, mined through $300 \mathrm{ft}$ vertically. Schmidt net, lower hemisphere. 


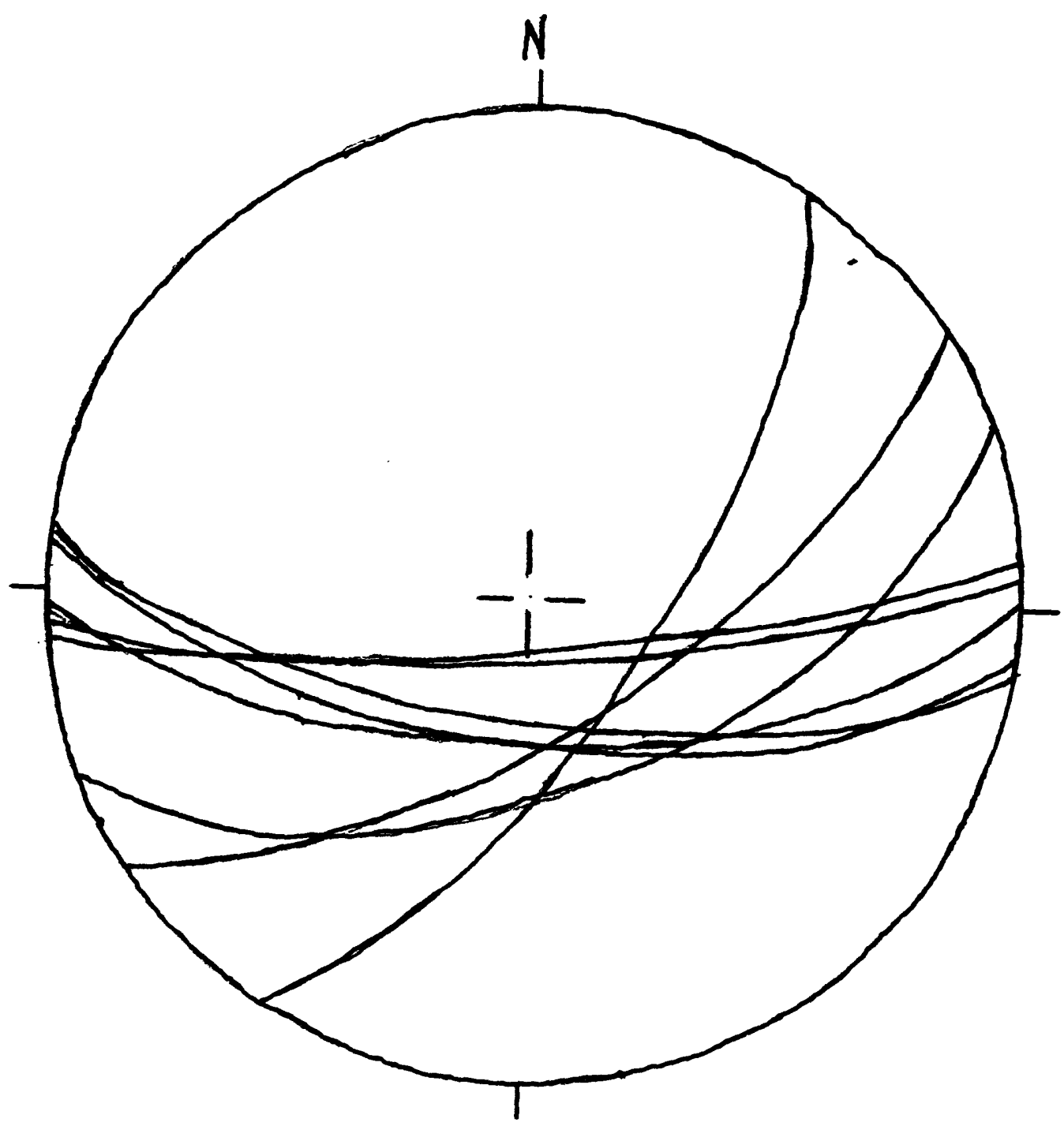

Figure 42. East to northeast trends in the 09 vein, an array of intermediate complexity mined through 1700 ft vertically. Schmidt net, lower hemisphere. 


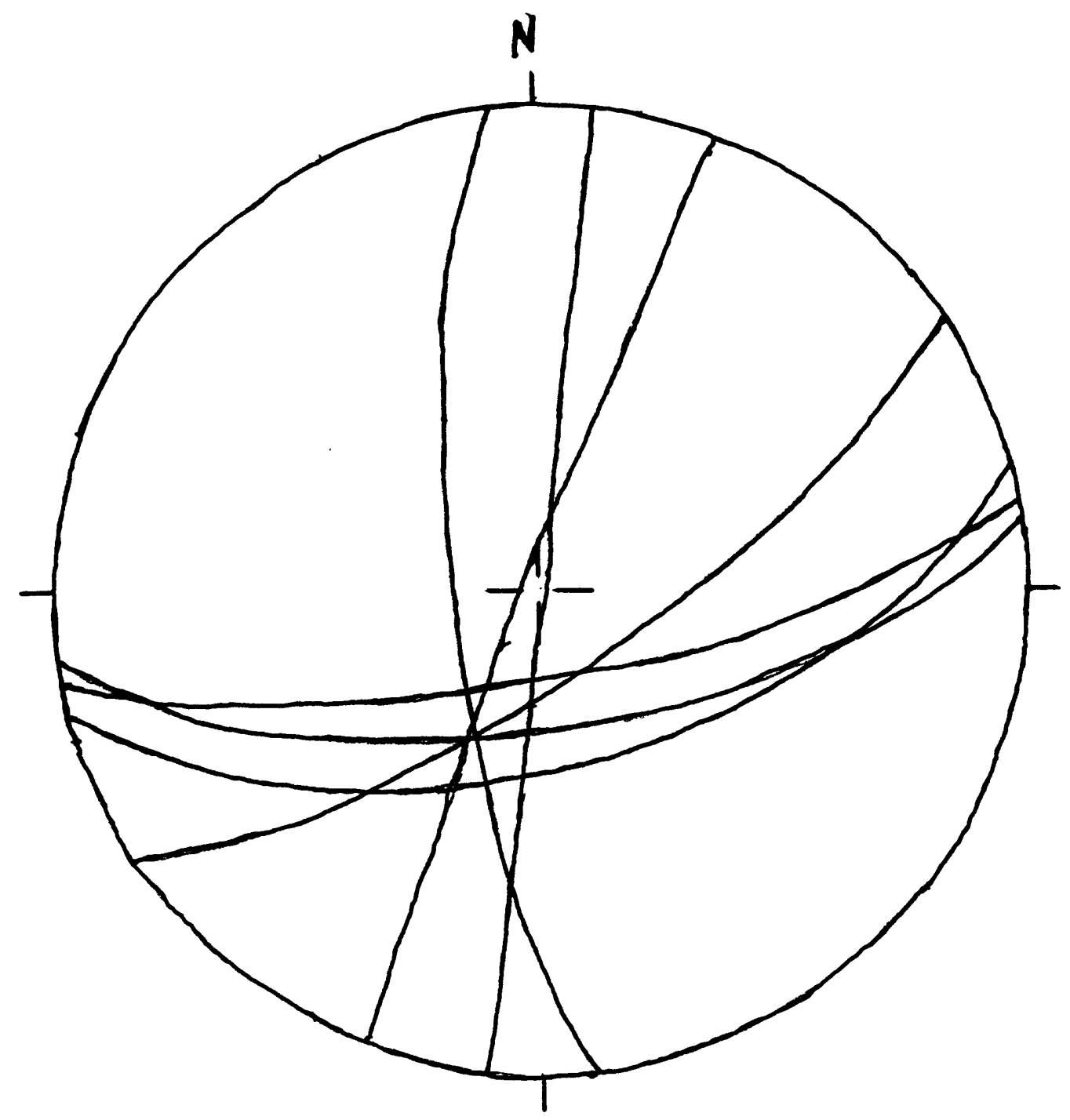

Eigure 43. Complex vein array. Hook vein, mined through $1500 \mathrm{ft}$ vertically. Schmidt net, lower hemisphere. 


\section{District-wide Data}

Faults are a prominent feature in the Coeur d' Alene district, cutting the cleavage. The Osburn fault, a brittle, gouge-forming fault of strike-slip origin, is younger than and cuts other faults, many or most of which show some signs of mineralization and are therefore older and belong to class $b$, although some of them may have been reactivated during Osburn faulting (this would seem to apply mostly to nearby ones).

The faults of Class (b) (Fig. 44) show a remarkable anastomosing pattern (see Hobbs and others, 1965, Plates 2-5). The pattern similarity (Fig. 45) to that in Fig. 9 of Gapais and others, 1987, is noteworthy. Individual faults show many strongly curved outcrop patterns. The Kruger fault (Hobbs and others, 1965, Plate 2), for example, changes trend along strike from N85W $70 \mathrm{SW}$ to N70W, 50SW, to NOOW $40 \mathrm{~W}$. The result is that faults join at various angles in the anastomosing pattern. Three faults described by Hobbs and others, 1965, P. 99, the Standard (reverse, N3OW 75NE), the Erisco (reverse?, N05E 8DSE, N20E, $70 \mathrm{SE}$, and N65W 85SW), and the Puritan (normal, N2OW 60NE, NDOE 90E), join together in a way that suggested the possibility of contemporaneous movement to Hobbs and others (1965).

From the descriptions by Hobbe and others (1965, p. 71-112), many of the more or less mineralized, faults of Class $b$ show evidence of high-angle reverse movements, whereas many others of the same sort show evidence of normal movement. Dip-slip slickenlines are mentioned for one fault. Faults of the sort here described, seen by us in the Sunshine mine, commonly show elickenlines plunging steeply to the solthwest, a feature that, may be more common in the district than the literature suggests. This view is supported by the cited literature showing primarily dip-slip movements.

A compilation of 58 Class b fault attitudes from Hobbs and others (1965, p. 71-112, and Plates 2-5) was analyzed in a BETA diagram; as mentioned earlier, the pattern is like that of veins as shown in Figure 38. Trends nearly range the compase; northeast faxlts dip mostly southeast, and northwest faults dip mostly southwest; east-west faults dip mostly south. The dominant trend is near N55W. A etrong maximum (BETA-axis) is oriented 65 S.3ow, yielding a steep southwesterly plunge in the faults and close to parallel to the observed slickenlines.

In the Lookout anticline, the Moe-Reindeer Queen mineral belt contains the operative structures (Fryklund, 1964, Table 23). Its general trend is near N7DW, off the N8OW trend of the Osburn fault in its vicinity and off the N60W "average" cleavage trend (Fig. 23. Fault and vein orientations from Fryklund, 1964, Table 2.3; Hobbs and others, 1965, Plate 5; and Therialdt, 1989, Plates 1-3, provide detailed data for structural geometric analysis. Figures 46 and 47 give PI and BETA diagrams

respectively for mineralized faults and veins in the Lookout anticline. They are similar to the same diagrams for cleavage (Eigures 22 and 23 ).

Early reverse faldts in the northeastern part of the district trend northerly and are of pre-mineralization age (Campo, 1984, p. 59). WNW normal faults correlated by us to 


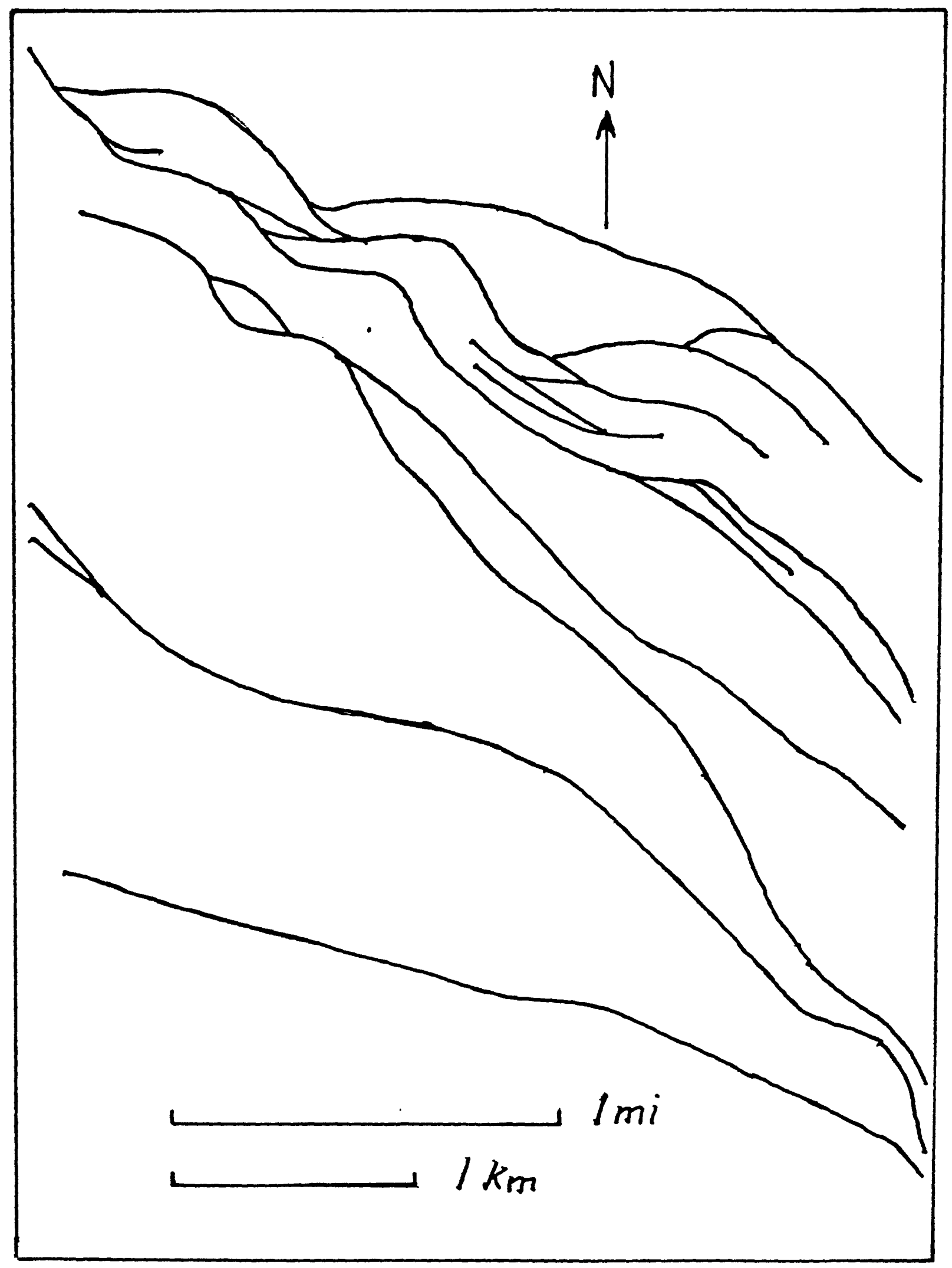

Figure 44. Anastomosing faluts in the Coeur d Alene district, from Hobbs and others, 1965, Plate 2. 


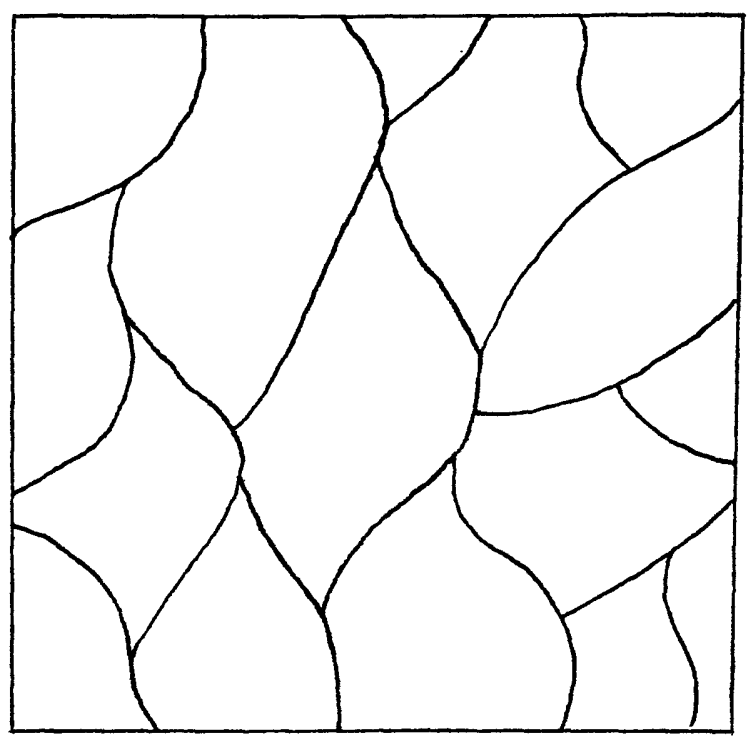

Figure 45. Sketch after Gapais and others, 1987, to show anastomosing fractures in a section perpendicular to the fractures and to the slip lire. Rod-shaped elements are predicted. 


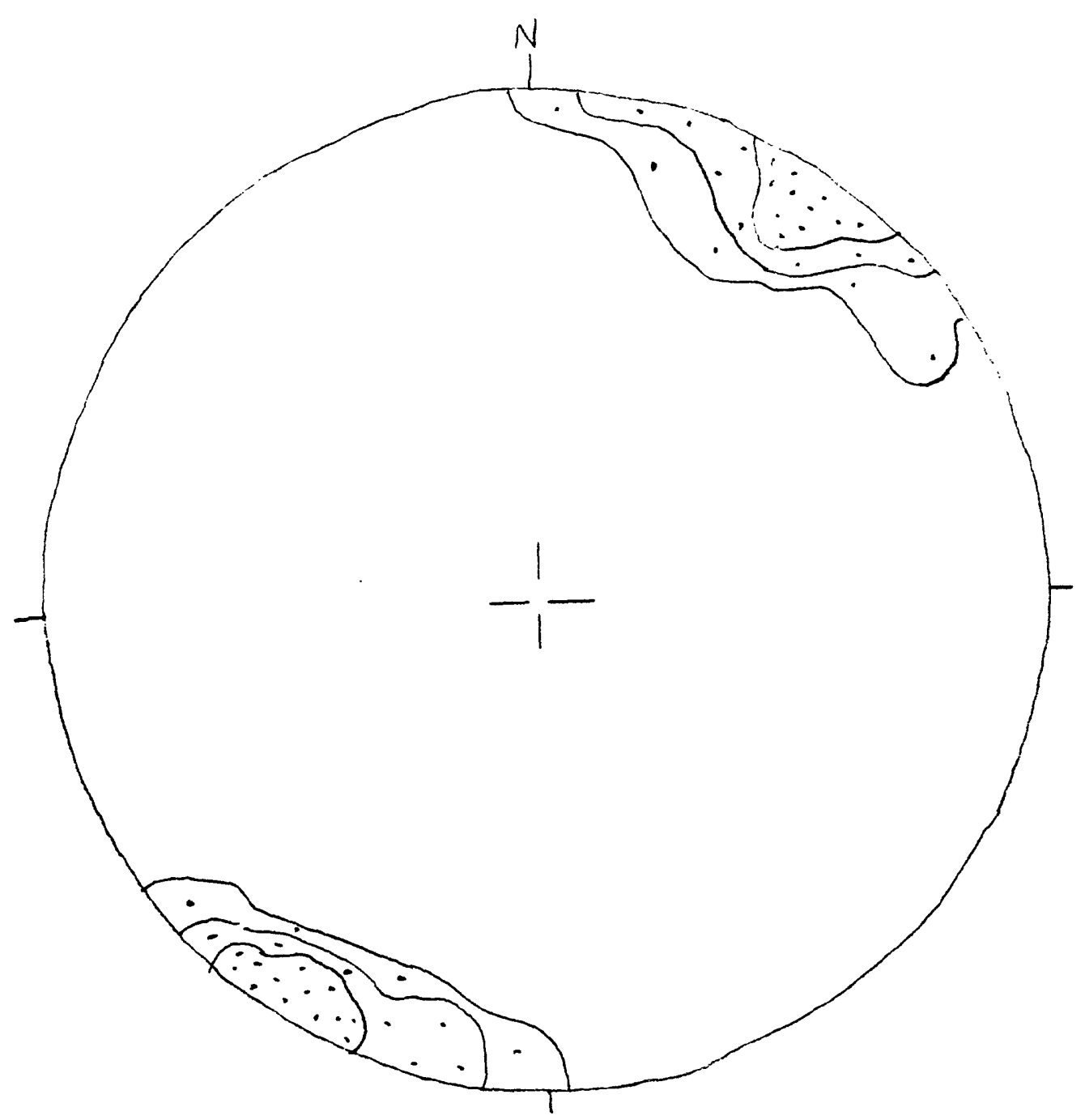

Eigure 46. PI diagram. mineralized faults and veins, Lookout anticline subarea, Coeur d'Alene district, Idaho. $\mathrm{N}=45$. Average faults $\mathrm{N} 55 \mathrm{~W}, 90 \mathrm{SW}$. Contours at 3,6 , and $9 \%$ per $1 \%$ area. Schmidt net, lower hemisphere. 


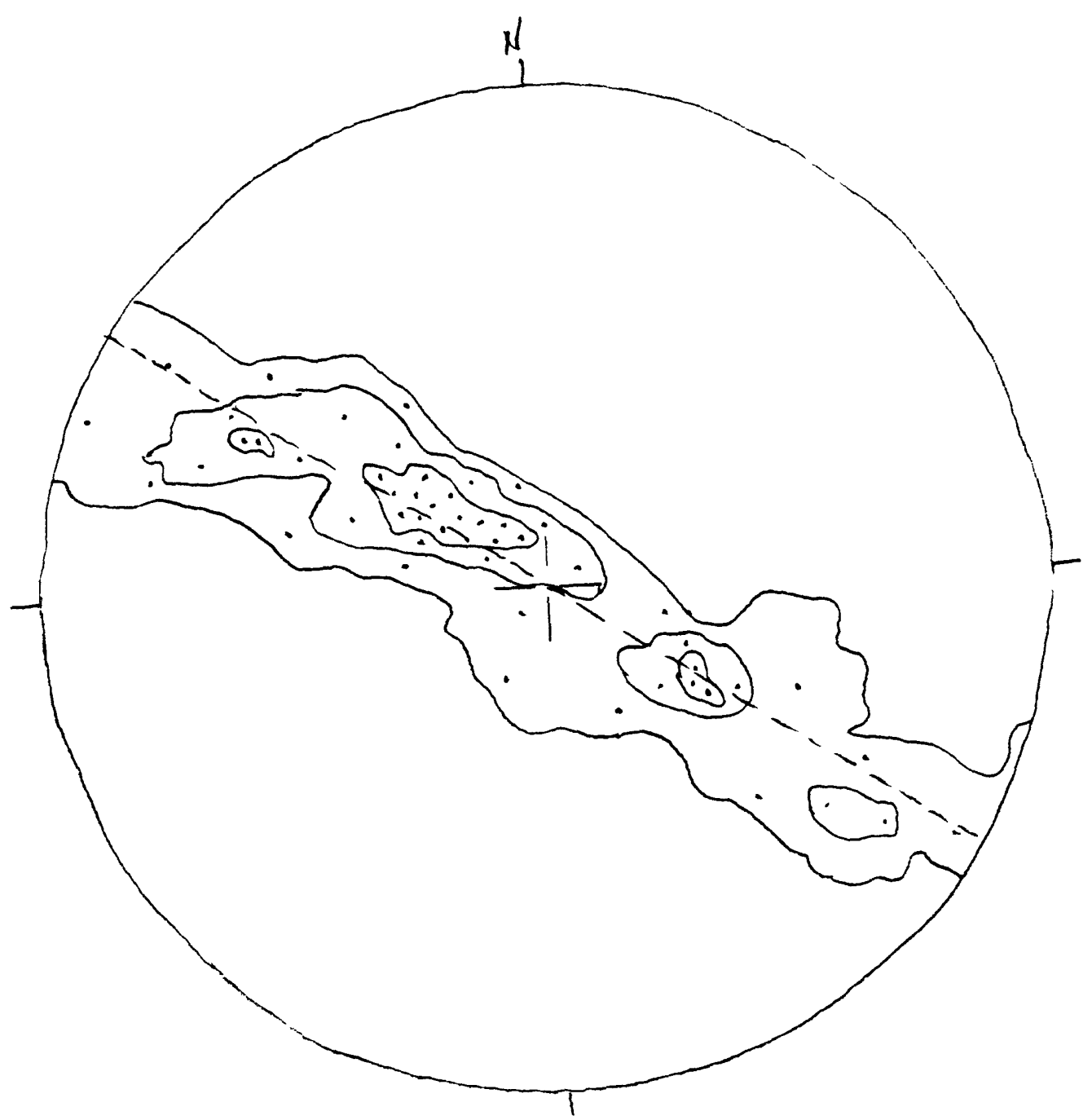

Eigure 47. BETA diagram. Mineralized faults and veins, Lookout anticline subarea, Coeur $d^{\prime}$ Alene district, Idaho. Girdle N58W 89NE. $\quad N=990$ points from the intersections of 45 planes. Contours at $2,4,6 \%$ per $1 \%$ area. Schmidt net, lower hemisphere. 
Class b are later and are mineralized. Some northerly faulte were reactivated in post-ore time. In general, it appeared possible that these two fault sets were a conjugate pair. However, stereographic analysis quickly destroyed that idea.

The array of mineral belts with relation to the TEZ is shown in Eigure 1. The mineral belt pattern lies athwart the TFZ; belts outside the TEZ are subparallel to its trend ( $770-75 \mathrm{~W}$ ), whereas those inside the TEZ have an average N6OW trend. Accordingly vein orientations within the mineral belts (Fryklund, 1964, Table 23) are considered in two sets for structural geometric analysis. As above, the small data set may not be representative of the total vein pattern.

Set 1 is from mineral belts $1,2,3$, and 7 (Fig. 1), marginal to the TEZ. Two principal fracture/vein sets emerge from Set 1 (Eig. 48). Set 2 is from mineral belts 4,5 , and 6 , within the TEZ. Two principal fracture/vein sets emerge from set 2 as well (Fig. 49). Substantial, systematic differences exist between the two mineral belt sets. In each case, the two vein sets are near $30^{\circ}$ apart. Note that the vein fractures of set 2 lie within mineral belts trending near N6OW and lying within the TEZ.

\section{Post-mineral Eaults}

Post-mineral faults, exemplified by those in the Sunshine mine, are considered next; the domains treated here are given in Eigure 2. Faults in Domain 1 range widely in their orientations. Average data are given in Figures 50 and 51 , showing the average fault trend to be near $N 81 W 70 \mathrm{WW}$. This value does not help much with interpretation. Considering the possibility of groups of faults around certain preferred trends, it emerges that $25 \%$ of those measured are scattered fairly uniformly over NoOW to N55W and NOOE to N65E. The remaining $75 \%$ cluster in three groups by strike frequency: (a) N56W to N80W, (b) $N 81 \mathrm{~W}$ to $\mathrm{S} 79 \mathrm{~W}$, and (c) N78E to N66E, shown in Figures 52,53 , and 54 . The average fault orientations from the three sets are composited in Figure 55 .

Faults in Domain 2 of the Sunshine mine show complexities in their distribution not seen in other mine domains (Figs. 56 and 57). The partial girdle near $N 85 \mathrm{~W}$ in Figure 57 is similar to that of similar plote in the other domains. The crossing partial girdle is different. As in the other domains, fault trends are tested by cluster analysis of strikes. Major clusters lie in (a) N34W to N55W (Eig. 58), (b) N56W to N74W (Eig. 59), (c) N75W to N85E (Eig. 60), (d) N84E to N65E (Eig. 61), and (e) N64E to N45E (Fig. 62). Sets (b), (c), and (d) are most like those in Domain 1 in their trend and may be taken as belonging to the same sets; they contain $44 \%$ of the measured faults. Sets (a) and (e) may represent one or more fault sets, similar or of different ages; they contain 25\% of the faults measured. Detailed mine mapping would be required in an attempt to verify these things. The remaining $31 \%$ of the faults are scattered more or less randomly over NDOE to N44E and NOOW to N33W. Their detail cannot be considered here on the basis of available information. All the average faults in Figures $58-62$ are compiled in Figure 63 . The patterns are similar to those of the average faldts in Domain 1 , 


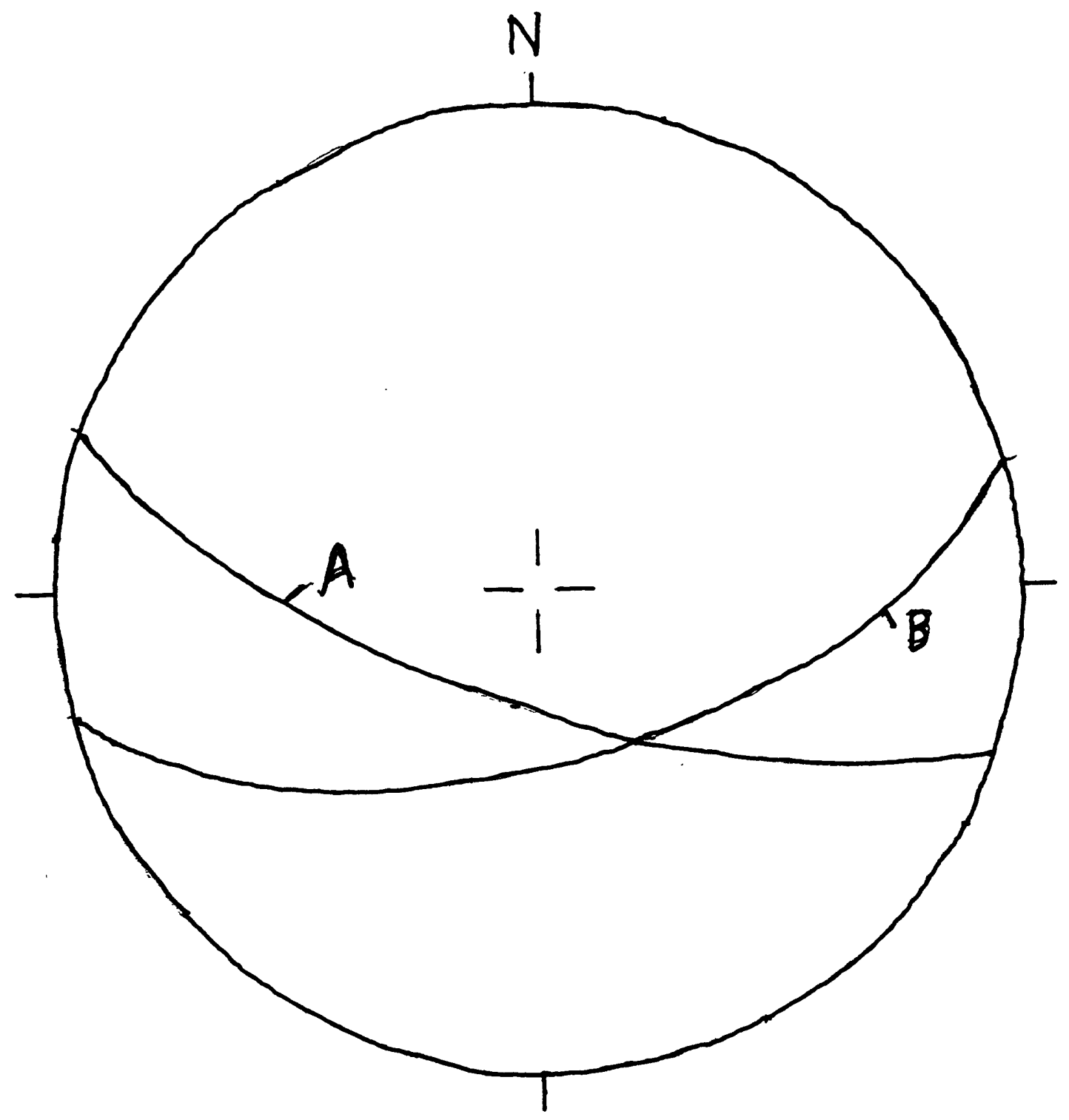

Eigure 48. Two averaged fracture/vein sets from the following mineral belts: 1. Page-Galconda-Lucky Eriday belt (Eryklund, 1964, Hercules belt, and 7 . Golconda- $A$ averages $N 70 W 70 \mathrm{~W}(N=41)$, parallel Table 23). Eracture set $A$ averagerages N75E 60SE $(N=17)$. Data Table 2.3)
to the TEZ. Eracture set $B$ averages N75E are plotted on the lower hemisphere of the Schmidt equal-area
are plo stereonet. 


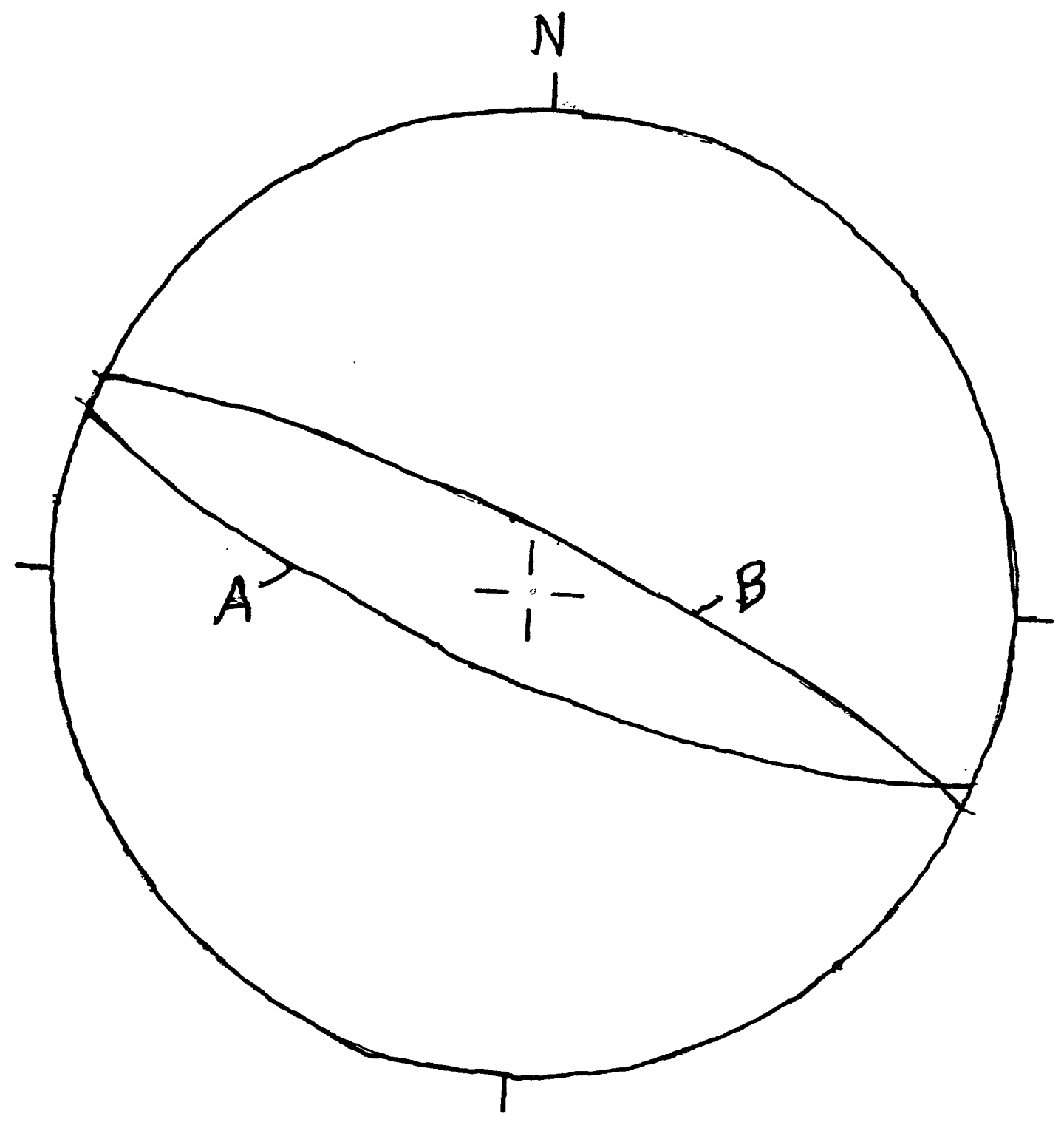

Eigure 49. Two averaged fracture/vein sets from the following mineral belts: 4. Tamarack-Marsh sub-belt, 5. Rex-Snowstorm belt, and 6. Gem-Goldhunter belt (Eryklund, 1964, Table 23). One set (A) averages $N 7 D W 75 \mathrm{SW}(\mathrm{N}=27)$, near parallel to the TEZ, but lying within mineral belts of N6DW trend. The other (B) averages N67W 80NE $(N=20)$. Data are plotted on the lower hemisphere of the Schmidt equal-area stereonet. 


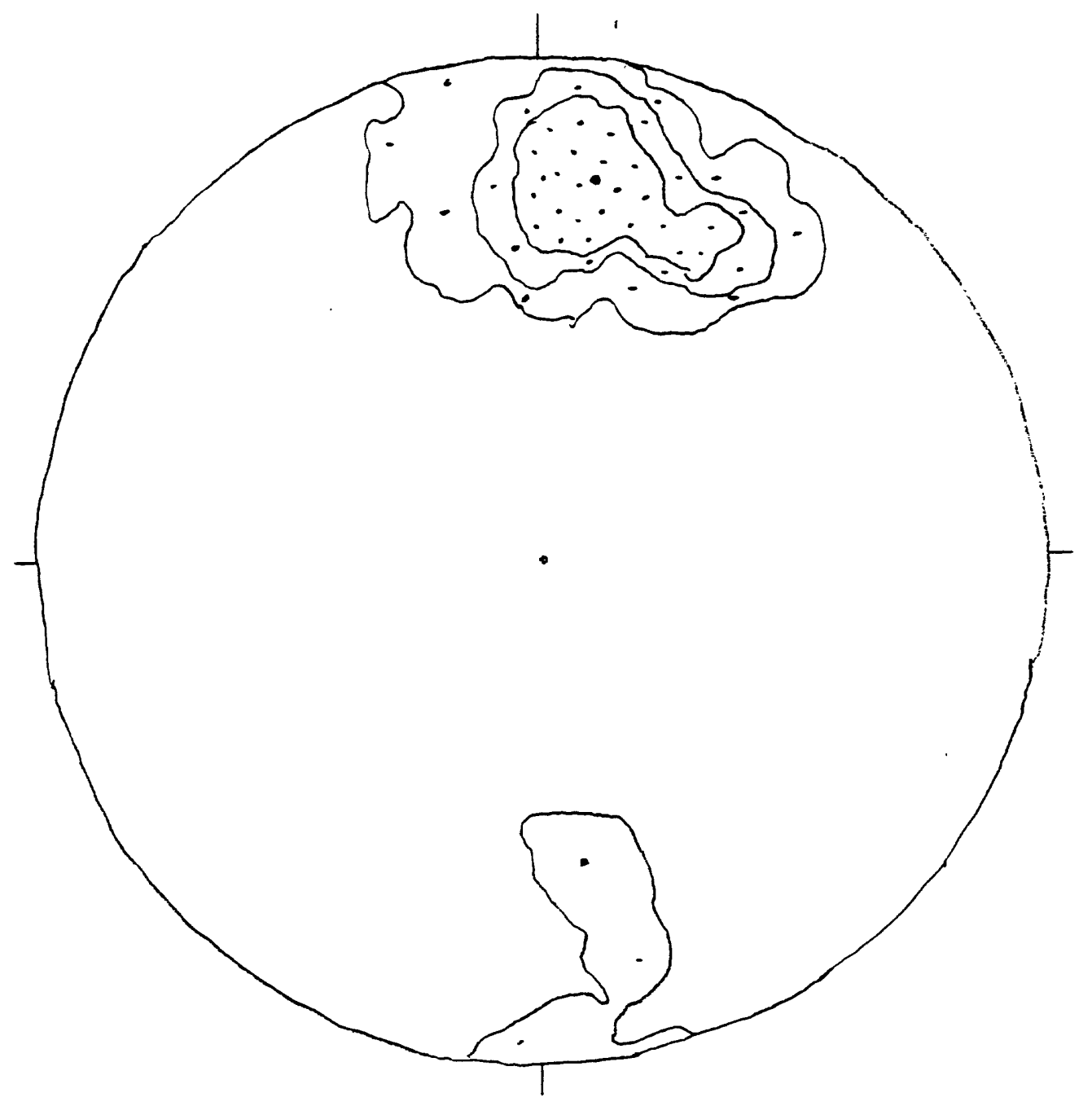

Eigure 50. PI diagram. Eaults in Domain 1, Sunshine mine, Coeur d' Alene district, Idaho. PI maximum 20 N09E. $N=293$. Contours at $2,4,6 \%$ per $1 \%$ area. Schmidt net, lower hemisphere. 


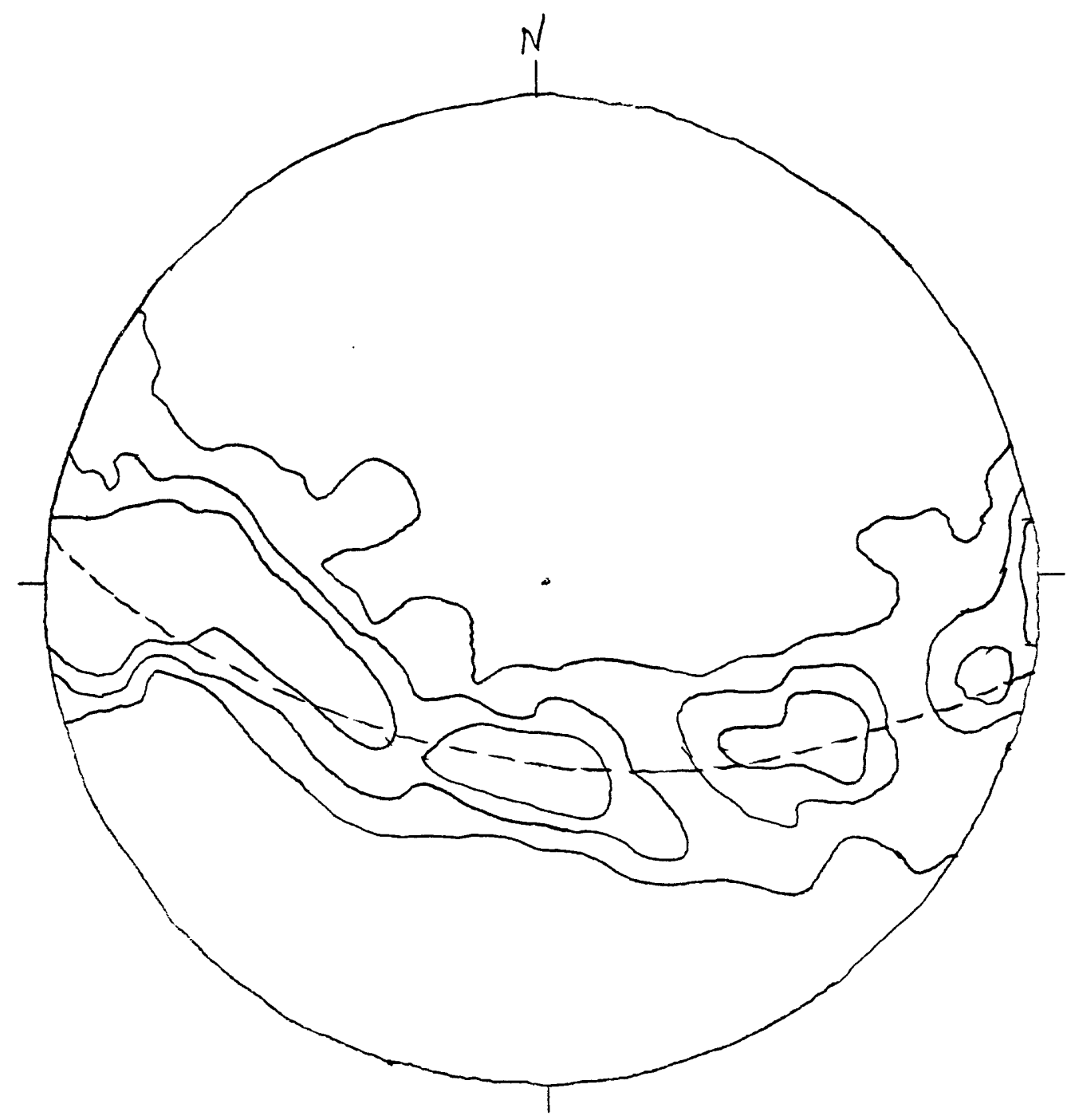

Eigure 51. BETA diagram. Eaults in Domain 1, Sunshine mine, Coeur d' Alene district, Idaho. intersections of 98 planes chosen randomly
Contours at $1,2,3 \%$ per $1 \%$ area. Schmidt net, lower hemisphere. 


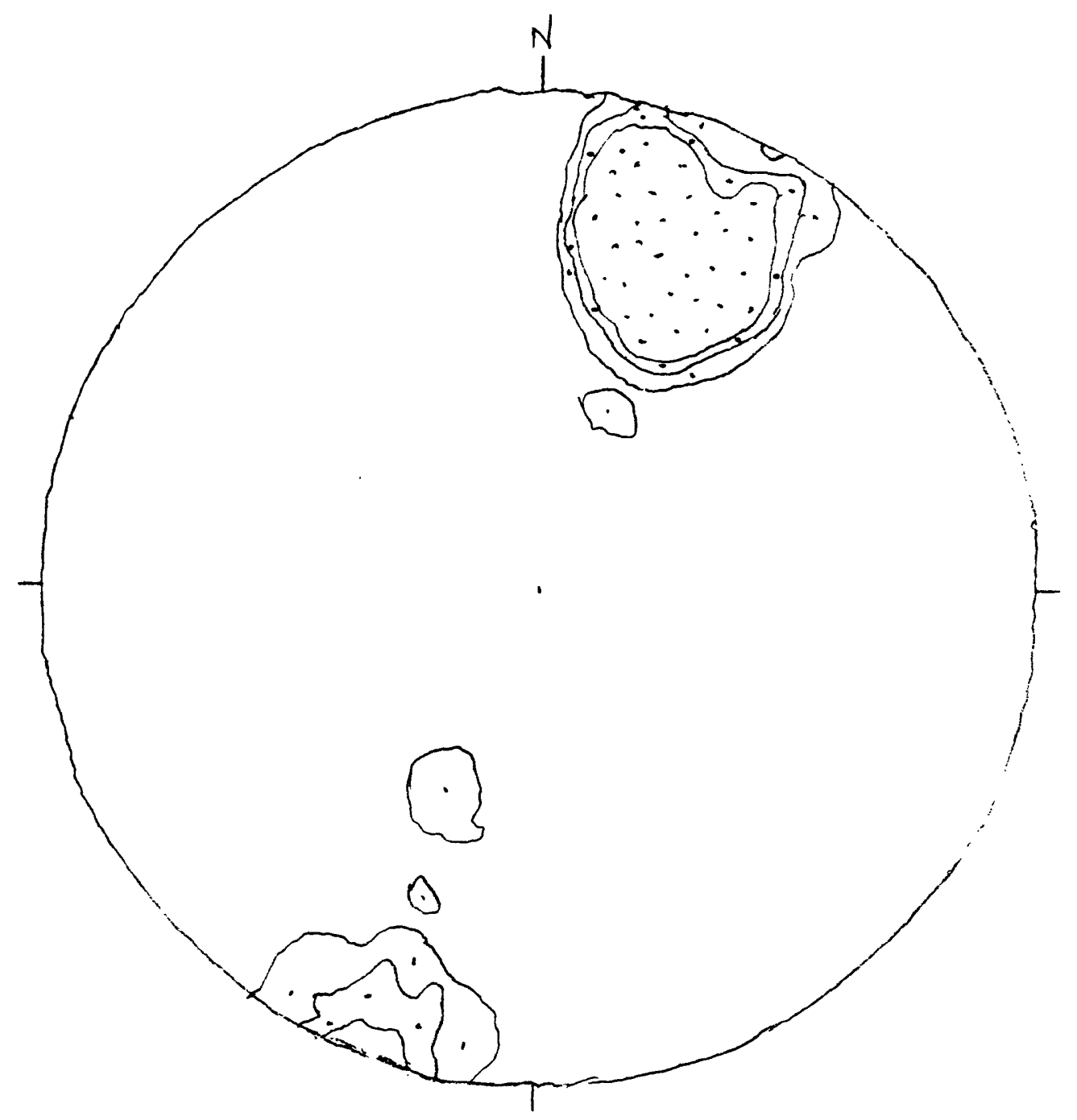

Eigure 52. PI on fault set (a), Domain 1, Sunshine mine, Coeur $d^{\circ}$ Alene district, Idaho. PI maxima $=28$ N2OE (average fault N70W 62SW) and $12 \mathrm{~S} 2 \mathrm{OW}$ (average fault N7OW $78 \mathrm{NE}$ ). $N=84$. Contours at $2,4,6 \%$ per $1 \%$ area. Schmidt net, lower hemisphere. 


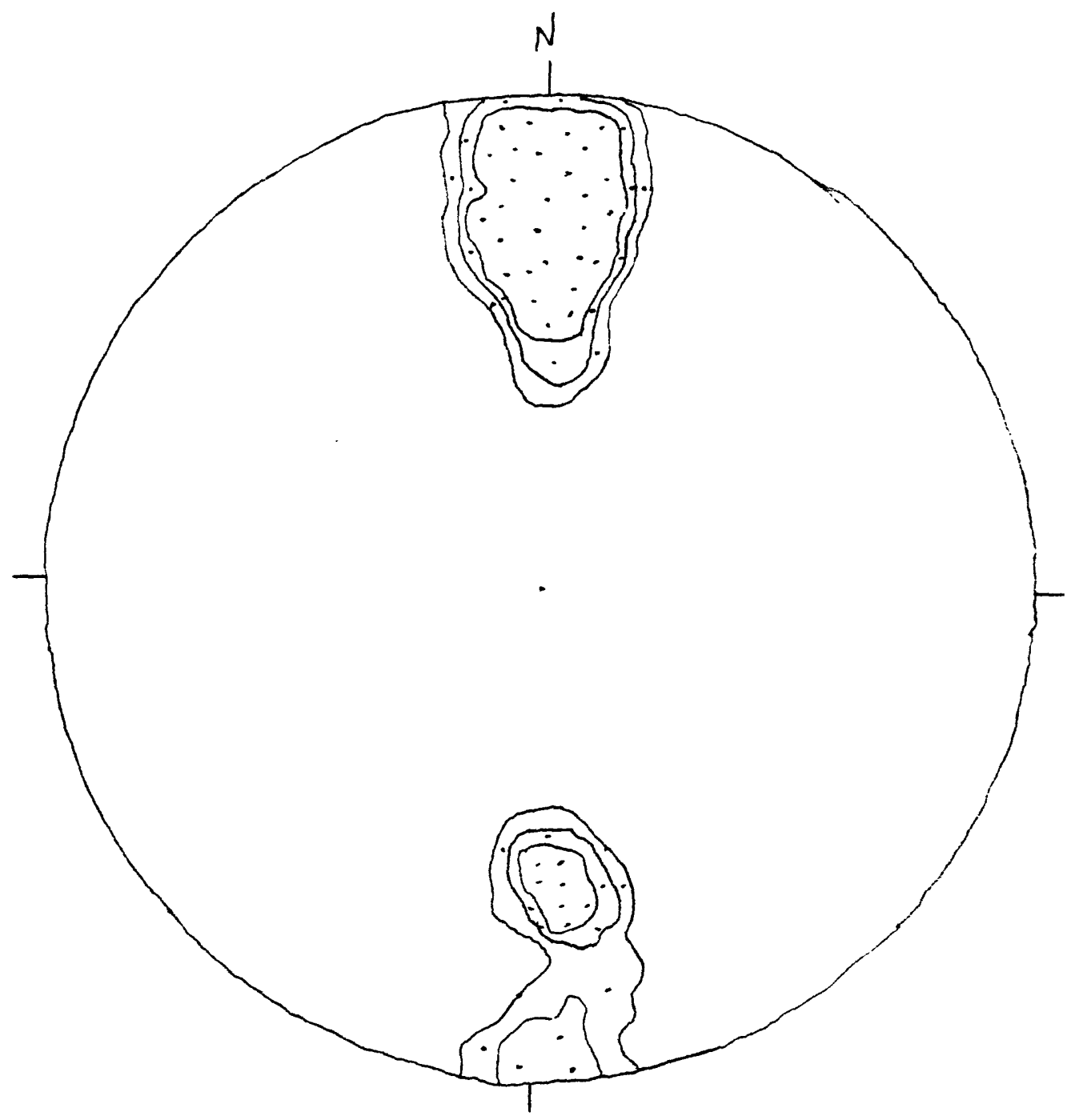

Figure 53. PI on fault set (b), Domain 1, Sunshine mine, Coeur $d^{\prime}$ Alene district, Idaho. PI maxima 25 NO2W (average fault = NB8E 65SE) and 40 SD2E (average fault N88E $50 \mathrm{NW}$ ). N $=101$. Contours at $2,4,6 \%$ per $1 \%$ area. Schmidt net, lower hemisphere. 


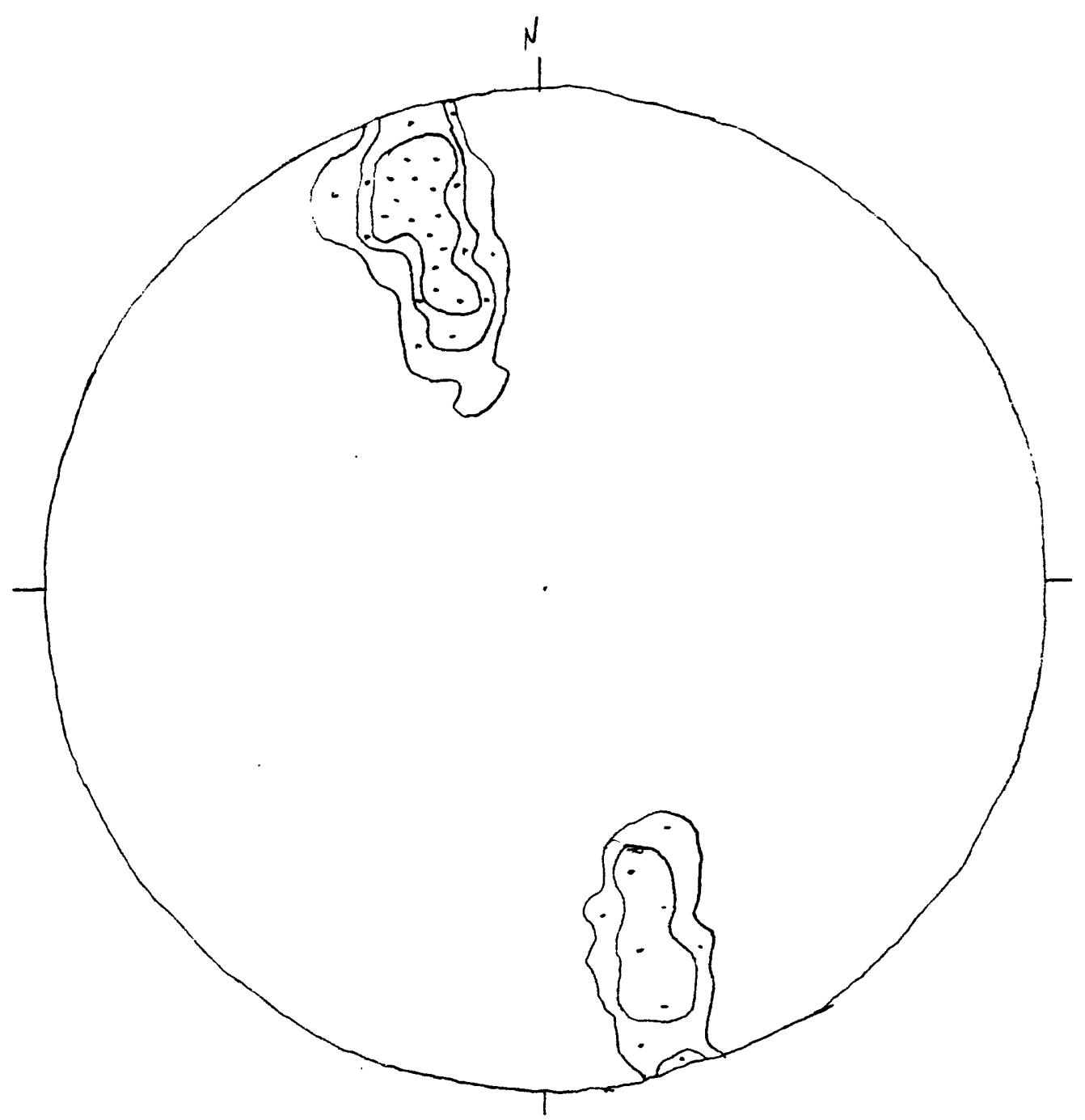

Figure 54. PI on fault set (c), Domain 1, Sunshine mine, Coeur $d^{-}$Alene district, Idaho. PI maxima at $20 \mathrm{~N} 17 \mathrm{~W}$ (average fault = $\mathrm{N} 73 \mathrm{E} 7 \mathrm{OSE}$ ) and $28 \mathrm{~S} 17 \mathrm{E}$ (average fault $=\mathrm{N} 73 \mathrm{E} 62 \mathrm{NW}$ ). $\mathrm{N}=35$. Contours at $5,10,15 \%$ per $1 \%$ area. Schmidt net, lower hemisphere. 


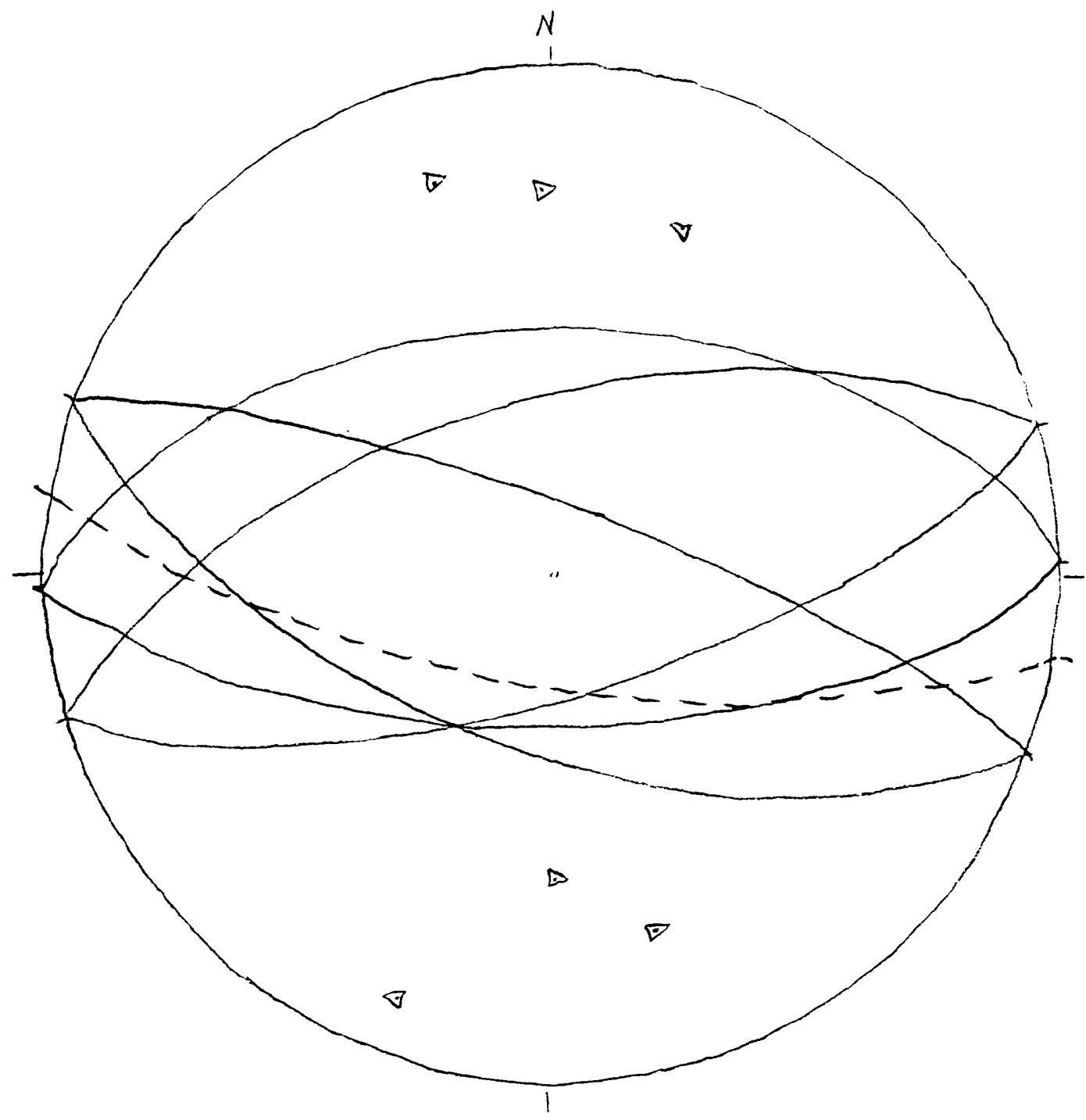

Figure 55. Composite plot of average faults in Domain 1, Sunshine mine, Coeur d' Alene district, Idaho. Average bedding is shown by the dashed line. Schmidt net, lower hemisphere. 


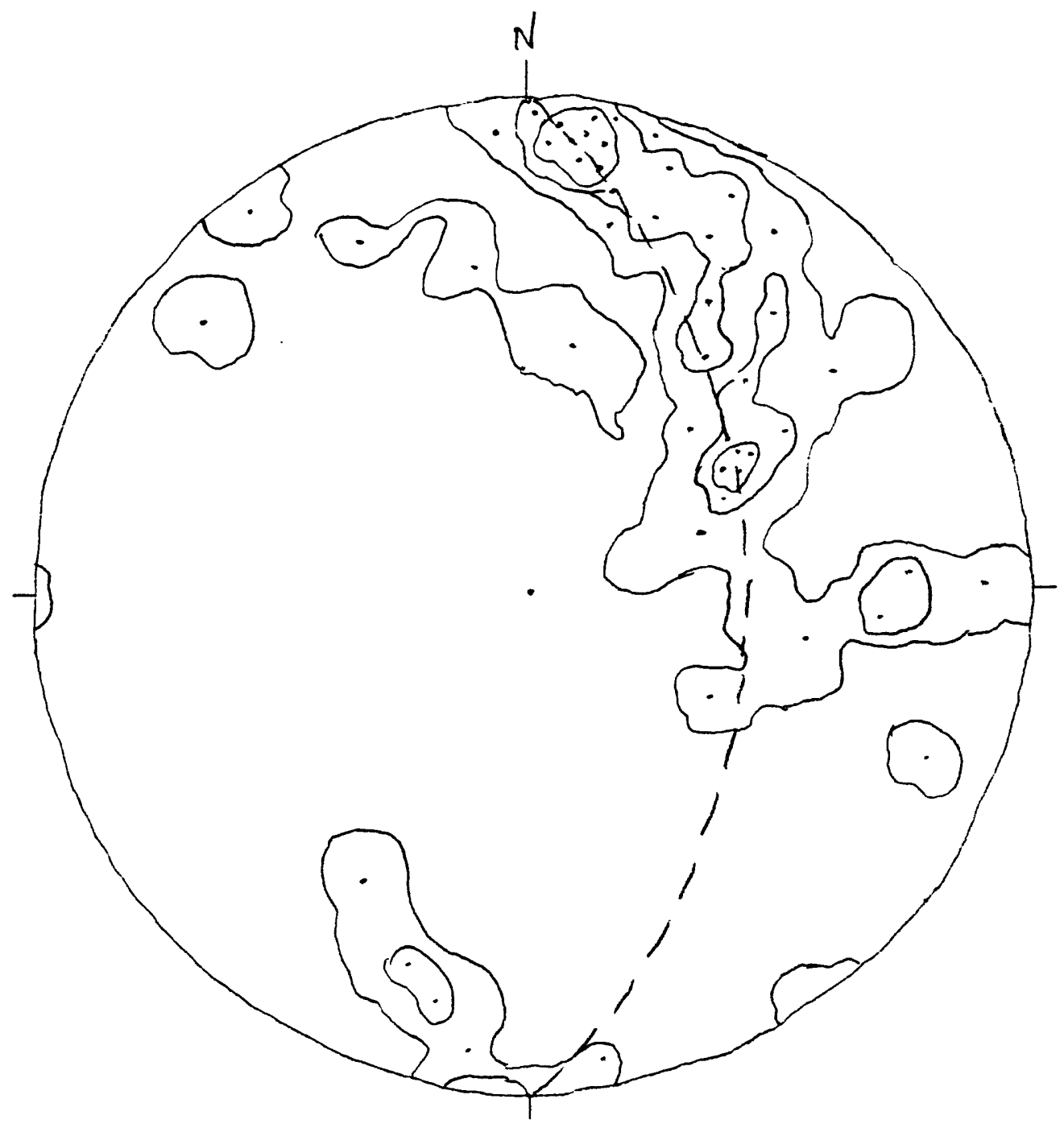

Figure 56. PI diagram. Faults in Domain 2, Sunshine mine, Coeur $d^{\prime}$ Alene district, Idaho. PI maximum not clearly defined. Poles lie principally in a crude partial girdle NOOE 57E that may be a small-circle girdle in fact. $N=100$ planes chosen randomly from a set of 545 . Contours at $2,4,6 \%$ per $1 \%$ area. Schmidt net, lower hemisphere. 


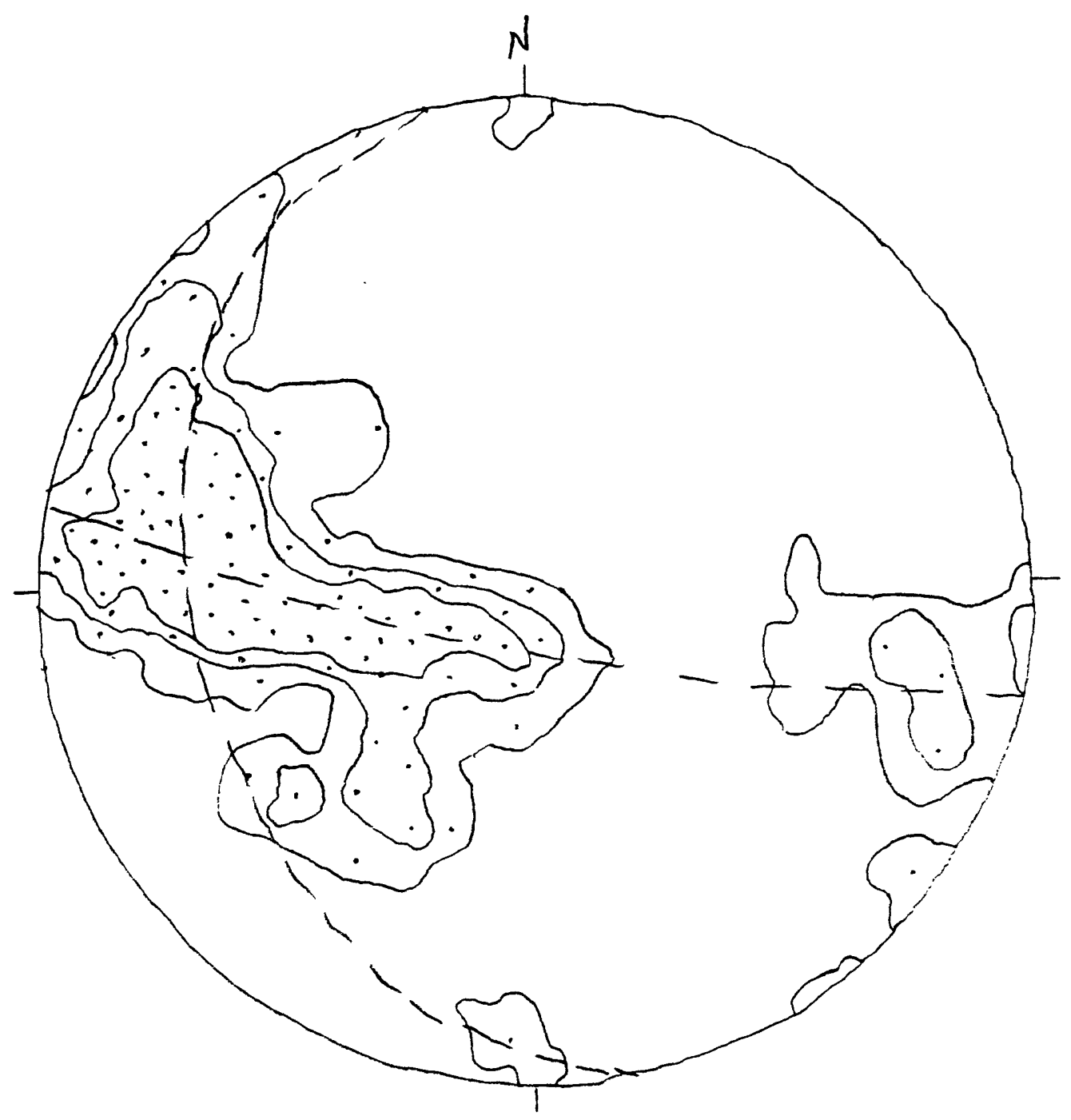

Figure 57. BETA diagram. Eaults in Domain 2, Sunshine mine, Coeur $d$ ' Alene district, Idaho. Irregular pattern approximated by a girdle N80W 80SW. A secondary girdle lies near N10W 30 . $W$. $\mathrm{N}=4656$ points from intersections of 97 planes chosen randomly from a set of 545 . Contours at $1,2,3 \%$ per $1 \%$ area. Schmidt net, lower hemisphere. 


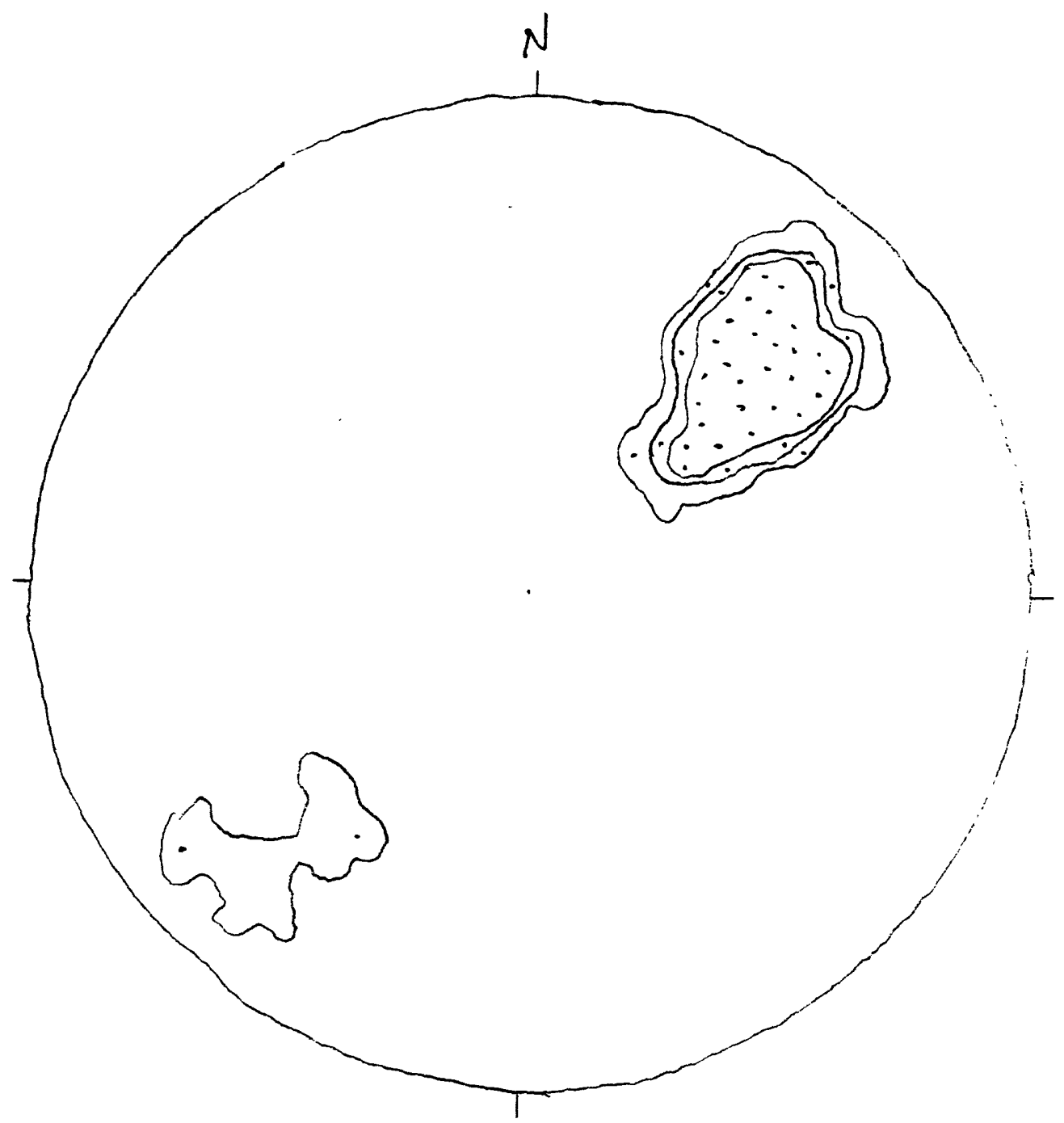

Eigure 58. PI on faults in set (a), Domain 2, Sunshine mine, Coeur $d^{*}$ Alene district, Idaho. PI maxima at 37 N45E (average fault $\mathrm{N} 45 \mathrm{~W} 53 \mathrm{SW}$ ) and $29 \mathrm{~S} 45 \mathrm{~W}$ (average fault $\mathrm{N} 45 \mathrm{~W} 61 \mathrm{NE}$ ). $\mathrm{N}=70$. Contours at $3,6,9 \%$ per $1 \%$ area. Schmidt net, lower hemisphere. 


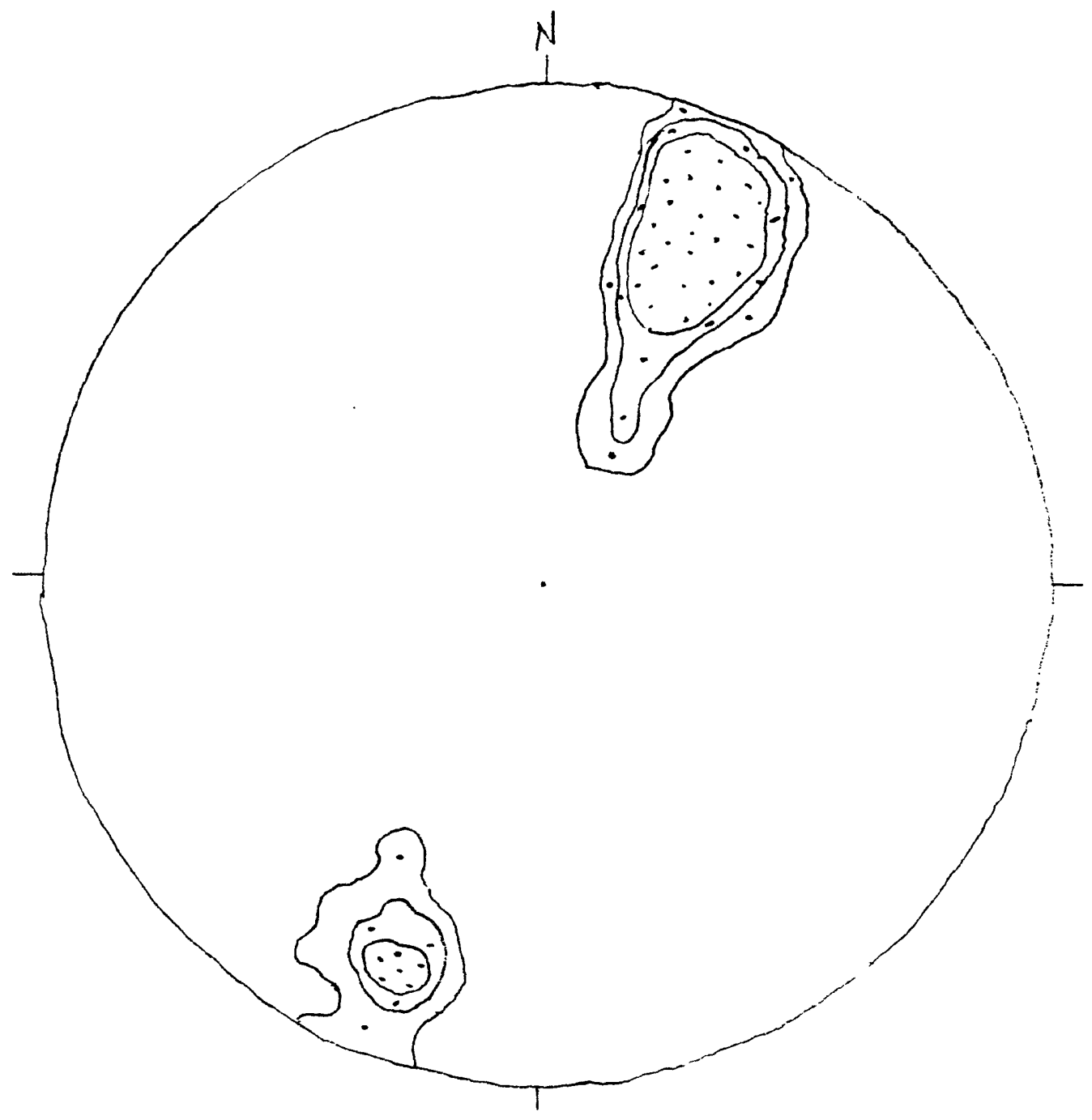

Eigure 59. PI on faulte in set (b), Domain 2, Sunshine mine, Coeur $d d^{\prime}$ Alene district, Idaho. PI maxima at 24 N21E (average fault $\mathrm{N} 69 \mathrm{~W} 64 \mathrm{SW}$ ) and $18 \mathrm{~S} 21 \mathrm{~W}$ (average fault $\mathrm{N} 69 \mathrm{~W} 72 \mathrm{NE}$ ). $\quad \mathrm{N}=103$. Contours at $3,6,9 \%$ per $1 \%$ area. Schmidt net, lower hemisphere. 


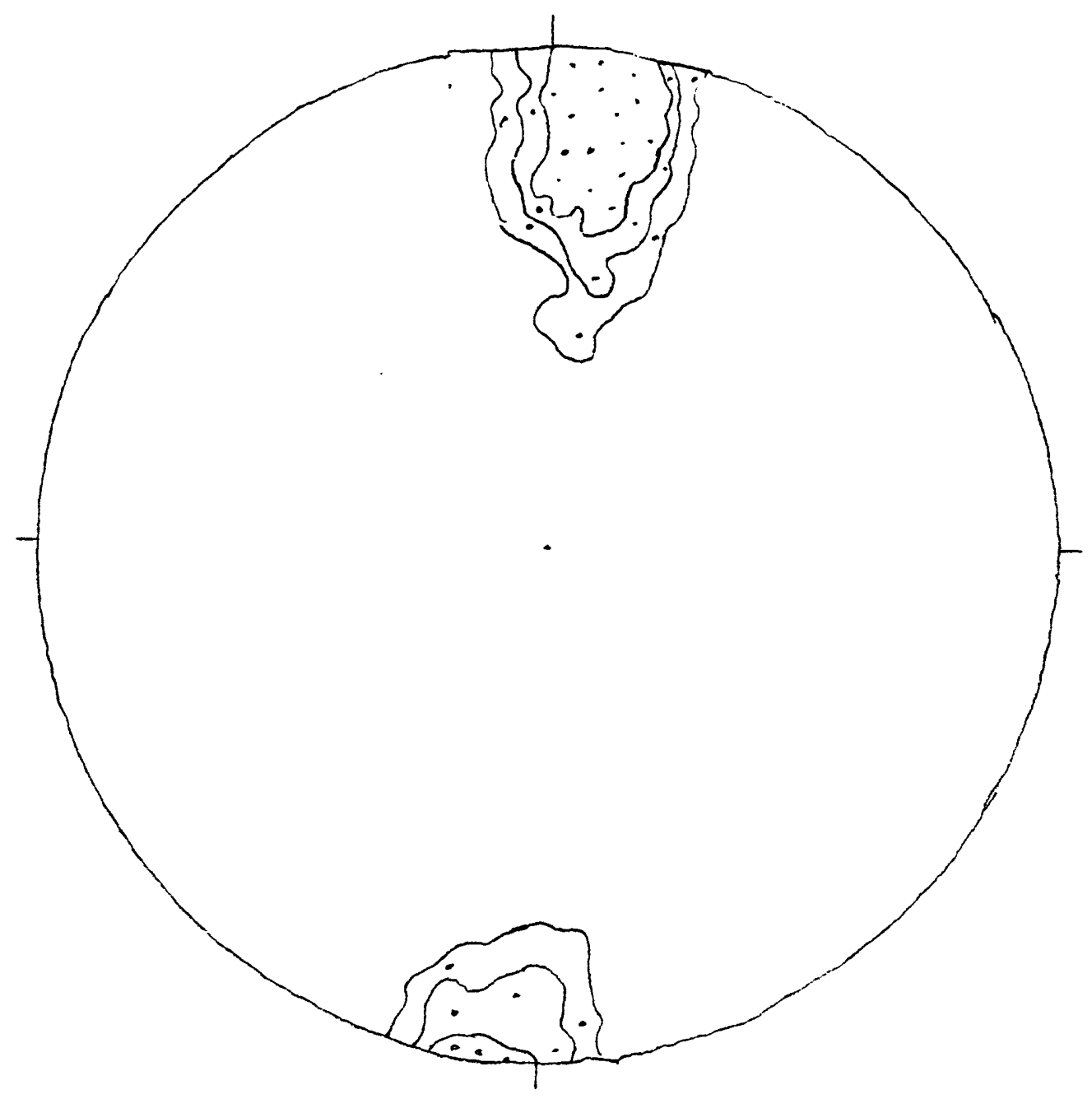

Eigure 60. PI on faults in set (c), Domain 2, Sunshine mine, Coeur $d$ ' Alene district, Idaho. PI maximum at 16 N05E (average fault N85W 74SW). $N=136$. Contours at $4,8,12 \%$ per $1 \%$ area. Schmidt net, lower hemisphere. 


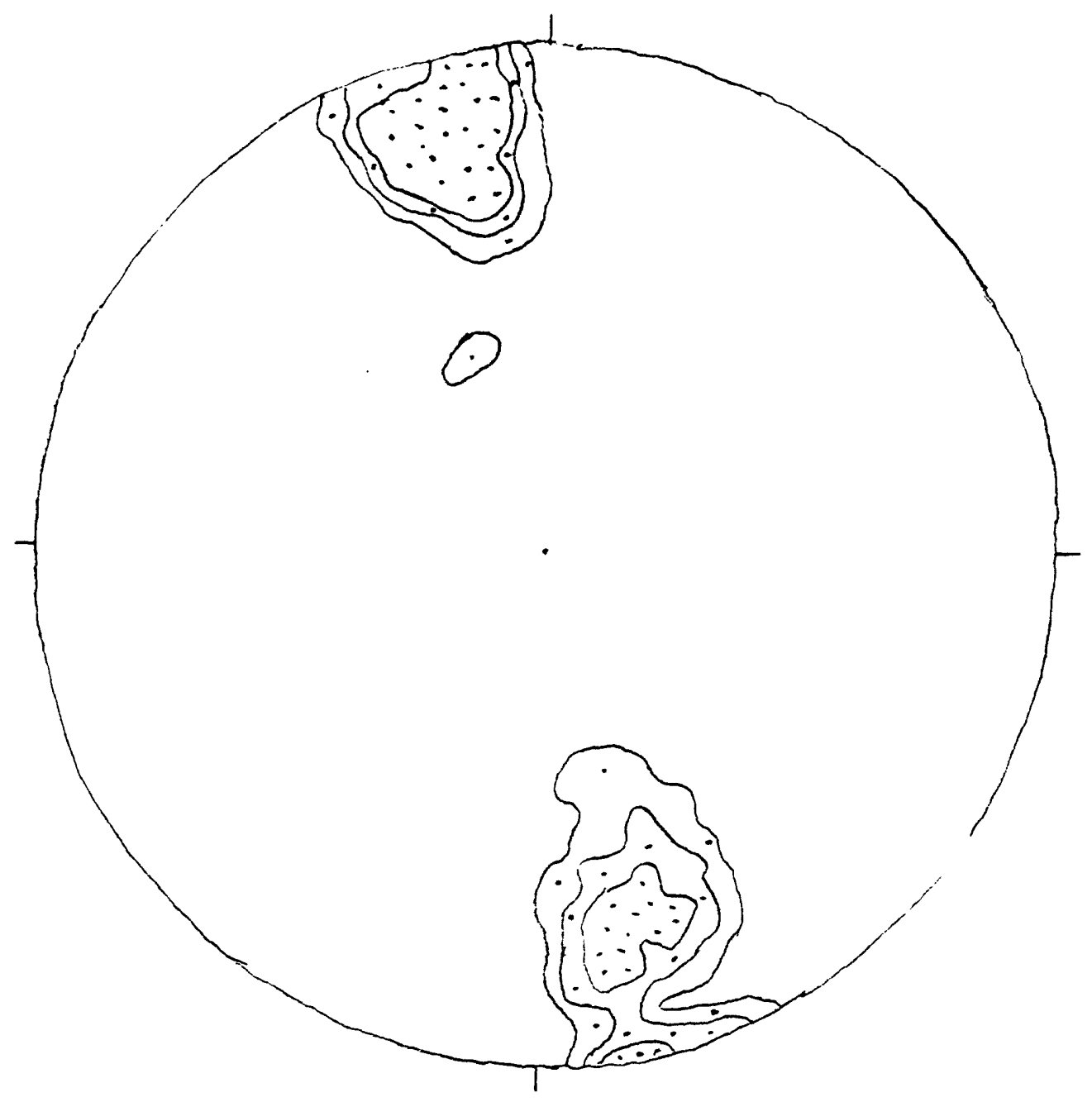

Figure 61. PI on faults in set (d), Domain 2, Sunshine mine, Coeur $d^{-}$Alene district, Idaho. PI maxima at $18 \mathrm{~N} 14 \mathrm{~W}$ (average fault $\mathrm{N} 76 \mathrm{E} 65 \mathrm{SE}$ ) and $25 \mathrm{~S} 18 \mathrm{E}$ (average fault $\mathrm{N} 76 \mathrm{E} 65 \mathrm{NW}$ ). $\mathrm{N}=56$. Contours at $3,6,9 \%$ per $1 \%$ area. Schmidt net, lower hemisphere. 


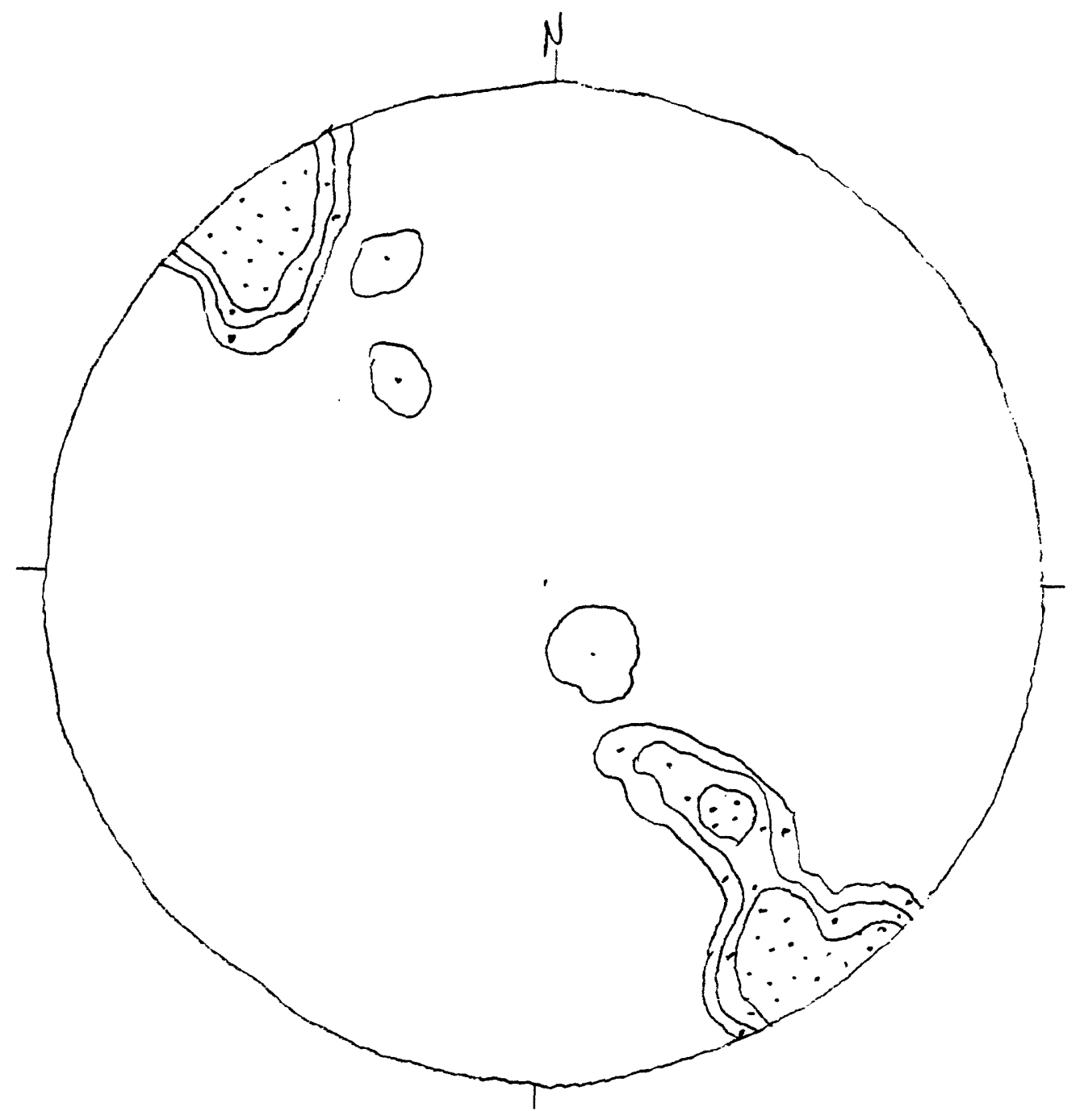

Eigure 62. PI on faults in set (e), Domain 2, Sunshine mine, Coeur d"Alene district, Idaho. PI maxima at 00 N38W (average fault N52E 9DSE) and 42 S38E (average fault N52E 48NW. $N=44$. Contours at $3,6,9 \%$ per $1 \%$ area. Schmidt net, lower hemisphere. 


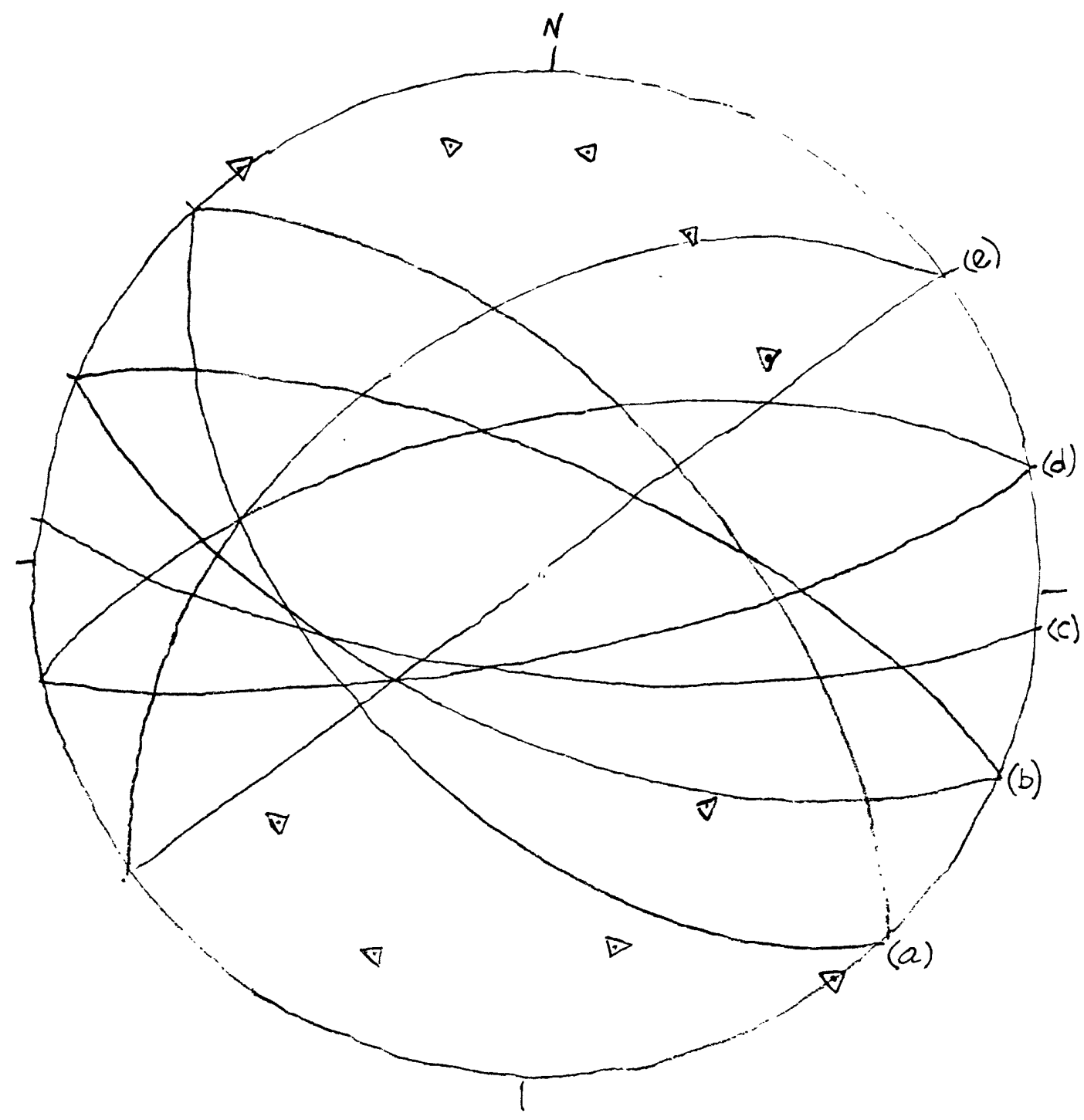

Figure 63. Average fault orientations from sets (a) N45W 5.3SW and $\mathrm{N} 45 \mathrm{~W} 61 \mathrm{NE}$ (interfault angle $67^{\circ}$ ); (b) N69W $64 \mathrm{SW}$ and $\mathrm{N} 69 \mathrm{~W} 72 \mathrm{NE}$ (interfault angle $47^{\circ}$ ); (c) N85W $74 \mathrm{SW}$; (d) N76E 76SE and N76E $65 \mathrm{NW}$ (interfault angle $41^{\circ}$ ); and (e) N52E $90 \mathrm{SE}$ and N52E $48 \mathrm{NW}$ (interfault angle $43^{\circ}$. Lower hemisphere, schmidt net. 
but more "extended". The small-circle girdle suggested by the larger part of the fault, poles is notable. Figures 64 and 65 show faults in Domain 3. The patterns are similar to those of the faults in Domain 2, and a detailed analysis for Domain 3 is therefore not done.

Early Fault, and Mineralization History

Early Faulting

The anastomosing fault patterns of class $b$ in the Coeur $d^{-}$ Alene district are reminiscent of the pattern hypothesized for anastomosing, ductile shear zones. The fact that slickenlines more or less parallel the line of fracture intersection (BETAaxis at 65 S30W from above) showe that slip is parallel to the fracture intersection line. The faults appear to show reverse and normal movements at different places. Hobbs and others, 1965, described such a possibility for the Standard, Frisco, and Puritan faults. They felt, however, that other explanations might be better; the concept of simultaneous development of reverse and normal faults nearby in the same ground and episode apparently was viewed as inconsistent with standard Andersonian fault mechanics (see Anderson, 1951).

Their simultaneity is interpreted by us initially from the presence of sulfides and alteration in varied degree within them. Evidence for strike-slip reactivation within them appears generally to be absent, judging from the cited descriptions.

Mineralization and alteration in many of the fractures show that, they pre-date the Laramide brittle deformation event; moreover, their physical characters show that bulk strain was semi-brittle if not plastic (Scholz, 1990, p. 36) during their formation. Mylonite shows greenschist facies conditions.

Pattern similarity to that for cleavage suggests a commonality of origin, although the near-parallelism may well be accidental. Moreover, the small N-size for this data set suggests that it is not truly representative of the vein array. Thus, any conclusions from it must be viewed as preliminary.

The fractures have a kind of "flattened" symmetry axially about the slip line, comparable to that shown by the regional cleavage. From the evidence given above to show early ductile slip in the faults, we consider that the faults are generated in semi-brittle to plastic (Scholz, 1990, p. 36) conditions; strain rate may have been relatively high, so that fractures rather than ductile shear occurred. Leach and others (1988) showed that mineralization occurred under $P-T$ conditions of more than $1-3 \mathrm{~kb}$ and above a minimum $\mathrm{T}$ of $350^{\circ} \mathrm{C}$. This is near the ductilebrittle strain transition in the crust, so semi-brittle to plastic strain is possible. We characterize it as apparent constriction fracture flow, extending the concept from Gapais and others, 1987 (see Fig. 45); it is considered as a variety of distributed flow by ductile slip along spaced fractures; the applicable strain ellipsoid qualitatively is a flattened prolate spheroid. Slip is along the line of the fracture intersections. A physical model might be a steep-"plunging" stack of oval rods, with slip parallel to the long axes of the rods. Differential, 


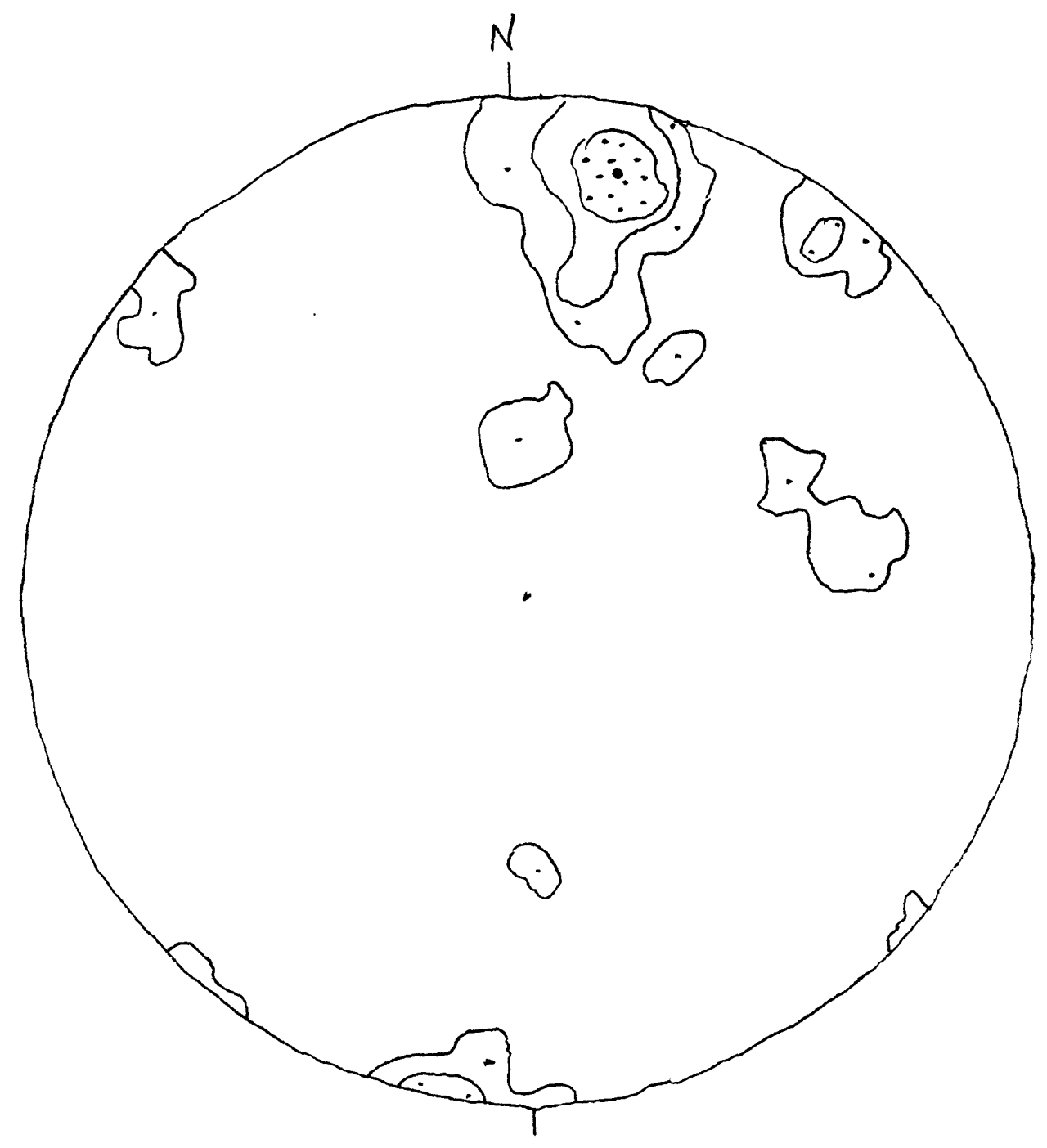

Eigure 64. PI diagram. Eaults in Domain 3, Sunshine mine, Coeur d' Alene district, Idaho. PI maximum $13 \mathrm{N15E} . \mathrm{N}=100$ planes chosen randomly from a set of 224 . Contours at $2.5,5$, $7.5 \%$ per $1 \%$ area. Schmidt net, lower hemisphere. 


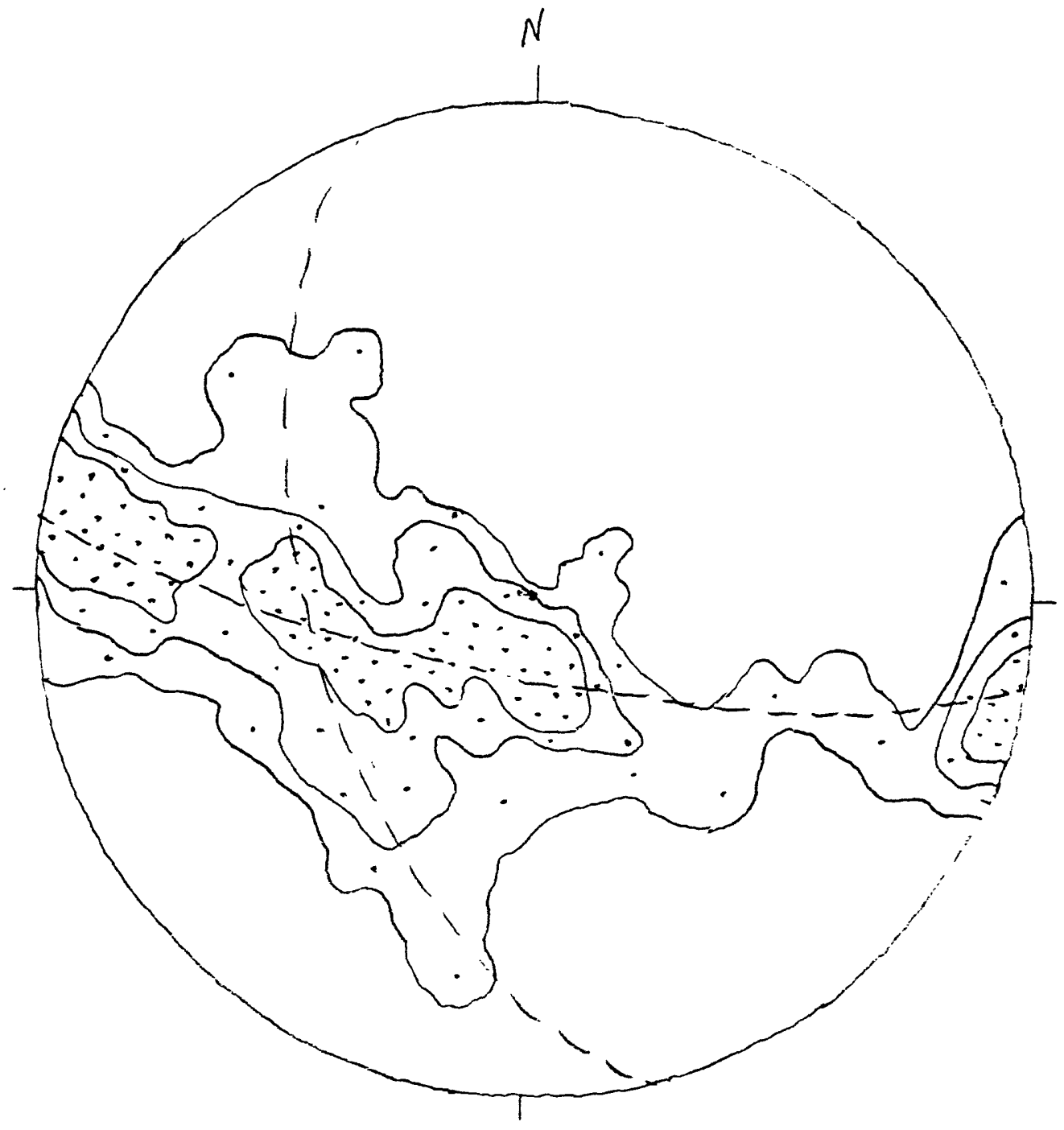

Eigure 65. BETA diagram. Faults in Domain 3, Sunshine mine, Coeur $d^{*}$ Alene district, Idaho. Girdle N80W 75SW. A secondary partial girdle is oriented $N 17 \mathrm{~W} 50 \mathrm{SW} . \mathrm{N}=4950$ points from intersections of 100 planes chosen randomly from a set of 224. Contours at $1,2,3 \%$ per $1 \%$ area. Schmidt net, lower hemisphere. 
non-homogeneous slip in this stack has the potential to generate both "normal" and "reverse" movements simultaneously in different parts of the stack. Inter-rod surfaces are strorigly curved, yet all share a common slip line. Thus, one may explain the curved (anastomosing) faults of Class $b$ in the Coeur $d$ Alenes on such a model. This, then, is a non-Andersonian fault model in which simultaneous reverse and normal movements are possible at the same time in different parts of the rock. Moreover, the slip line is parallel to the line of fracture intersection rather than at right angles to it as in Andersonian fracture systems.

Venkatakrishnan (1984, p. 107), based on mine map data and Fryklund 's 1964 Table 23, demonstrated two principal vein sets in the Silver Belt: N65W 65SW and N50E 30SE. Comparison to the Sunshine mine data described above raises the possibility that his data are not truly representative, owing to the small N-size. He stated that "The strong clustering of the two vein sets immediately suggests that both are controlled by different structural. . . parameters." He analyzed these sets by rotating them back to positions they would have had if they had been initiated as joint fractures when bedding was still horizontal. The vein rotation was to test the possibility of early joint control of veining, and his test showed no correlation to his proposed, early joint sets.

\section{Conditione of Mineralization}

Reid, 1984 , p. 49, suggested that the part of the fault system in the Coeur $d^{\prime}$ Alene district that controls the vein system was initiated during or soon after the East Kootenay orogeny, based on the presence of diabase dikes in major faults (Hobbs and others, 1965, p. 51-54), dated by Sorenson, 1972, at about 1,200 Ma. The isotopic diabase age may be spurious; it is rather common for diabase to take up radiogenic argon from the country rock and therefore to yield anomalously high ages. Moreover, the possibility exists that more than one age of diabase injection occurred--partly Precambrian and partly Tertiary, for example--in the faults; accordingly, diabase dikes may be unreliable age indicators at the present level of know ledge.

Evaluating the above suggestion, Campo, 1984, emphasized correctly that faults formed in pre-D2 time should show some effects of folding. Inasmuch as the faults (and their contained veins) are not folded in any degree, they should be younger than or late in D2; this view is supported by the fact that D2a folds and D2b cleavage reflect ductile (plastic) strain, whereas the Class b fault array (placed in D2c) appears to reflect semibrittle to plastic strain. Then it is conceivable, as also suggested above, that faldts are partly controlled by zones of strain softening along the ductile cleavage. This possibility may be explored through comparison of fault trends to cleavage trends. An additional way is to compare slip line orientation(s) for vein-controlling faults during mineralization, to cleavage slip-line orientation( $s$ ); that is done below.

The bulk of the Coelur $d^{\prime}$ Alene ore deposits is restricted to the Burke-Prichard transition and to the Revett-St. Regis 
transition. Competency changes at these transitions (argillite to quartzite) apparently promoted the opening of fractures to vein filling (not replacement; see Reid and others, 1975). Ore shoots occur either in quartzite or argillite, depending on slip sense, either normal or reverse, in dextral or sinistral oblique slip on particular fractures.

Leach and others (1988) showed that mineralization occurred under $P, T$ conditions of more than $1-3 \mathrm{~kb}$ and above a minimum $T$ of $350^{\circ} \mathrm{C}$. This is near the ductile-brittle strain transition in the crust; therefore, faulting prior to and during mineralization may have been near the ductile-brittle strain transition, leading to some drag fold development late in D2, due to ductile flow of less competent rocks in the walls of the largely brittle fallts. Such features are found but are relatively uncommon. They are particularly valuable as indicating slip direction on veined faults. Consistent with the above, from petrographic identification of mylonite on cleavage near veins, it is clear that mineralization occurred under greenschist facies conditions, late in the second metamorphism. Siderite both in the mylonite and in the veins supports this contention, as does the fact of siderite filling in openings created during faulting movement along the veins.

Drag folds related to north-south faults have been described by Campo (1984, p. 128). Hobbs and others (1965, p. 112) described drag folds in the walls of the Atlas fault, in the Lookout anticline subarea, indicative of sinistral strike-slip faulting. Its orientation is $N 57 \mathrm{~W}, 70 \mathrm{SW}$, from Theriault (1989, Plates 1-3); and it is a part of the D2c fault set, so oblique slip is indicated, normal-sinistral (providing two ages of $\mathrm{s}$ ip are not involved).

Consideration of the mineral belts (Fig. 1) in terms of the reconstruction given by Bennett and Venkatakrishnan (1982, Fig. 2) shows that they are in a target-like pattern closely associated with the Silver Synclinorium of Bennett and

Venkatakrishnan. These authors (1982, p. 1858) showed that all deposits in the Burke-Prichard and Revett-St. Regis transition zones (the larger part of the deposits mined in the district) are confined to their Silver synclinorium. Vein systems in early fractures are largely confined to the mineral belts, which lie somewhat off the trend of the modern Osburn fault, at an average orientation near N65W (Eigs. 48 and 49)). These figures are based on data given by Eryklund (1964, Table 23). The average trend of the modern Osburn fault across the district is near N80W, taken from Bennett and Venkatakrishnan (1982, Eig. 2).

\section{Silver Belt Phenomena}

Vein origin may be tested in some detail in the Sunshine mine, a major silver producer in the Silver Belt. Colson, 1961, p. 30-37, described the geology of the Sunshine mine, and we have extended that description above in some further detail. The Silver Syndicate vein (Colson, 1961, p. 32) belongs to the family of Class b faults. Of significance are its slip-line orientation and slip direction during mineralization, prior to possible faulting reactivation during the Laramide event. We have 
determined the movement during mineralization in the silver Syndicate fault to be reverse-sinistral oblique slip.

For the sunshine veins, the bulk symmetry of the strain features reflects the symmetry of the stress field in which strain occurred. The symmetry of the strain array is also a function of the mode of yielding, such as brittle, plastic, or transitional between brittle and plastic. Plastic strain may not be an option for the Sunshine veins, so the choices are seemingly between brittle and transitional strain types. As noted earlier, work by Leach and others, 1988 , permits the interpretation that vein development occurred in the semi-brittle field.

A brittle Andersonian fracture array would show one principal fracture set, maybe a weaker conjugate set, and perhaps contemporaneous extension fractures (see, e.g., Pollard and others, 1982). Extension fractures are not seen. Constant angular relations would result in sharply defined arrays. The vein pattern in Figure 38 hardly meets the requirements of brittle strain fabric symmetry. The one way in which the pattern might be achieved is in strongly rotational strain. Even here, would the rather symmetrical frequency of vein fractures be expected? We are unsure, but doubtful. Grooving and slickenlines developed synchronously with mineralization during such strain would lie in the shear plane perpendicular to the vein intersection line and thus near parallel to the strike line. Even if the larger part of the array is viewed as a special case of brittle fracture dominated by development of extension fractures, the fractures will pick up a component of shear strain as they rotate and be available for groove and slickenline development. The absence of slickenlines and grooves in the strike line shows that brittle Andersonian strain is not the operative mechanism to produce vein fractures.

Consistent with this is the absence of extension fractures.

For the foregoing reasons, then, we must consider carefully the alternative of a transition strain mode. As will develop below, we prefer the idea of semi-ductile strain. Neglecting the frequency distribution of vein shears, and concentrating on the wide range of vein trends (Eig. 38), we are struck by the axial symmetry of the pattern. It is virtually identical to the cleavage patterns developed during ductile yielding in apparent constriction flow (inferred from Ramsay and Huber, 1983, p. 172; think also of flow patterns, e.g., in salt intrusions). Here, as above, the vein fractures are viewed as synchronous throughout; all the veins in the axial array developed during a single movement phase. In apparent constriction flow, the slip planes are radially distributed and intersect in the slip line. For the Sunshine veins, then, here postulated to develop in apparent constriction fracture flow in the semi-ductile strain range, the planes all intersect in the slip line. Syn-mineralization slickenlines and grooves for this strain pattern lie parallel to the line defined by the average of the vein intersections and therefore near the dip line of the veins/ore shoots. That parallelism itself is strong evidence in support of the proposed strain in the semi-ductile field.

A related question is that of the general movement plan in the apparent constriction fracture flow model. Figure 38 
emphasizes the dominant N9OE vein trend. Thus, the dominant slip plane is in $E-W$. But was the hanging wall down (normal) or up (high-angle reverse)? The criteria involving preferred filling in the "steeps" or in the "flats" can help with this question. Although both types of filling are seen, filling in the "flats" is dominant, supporting the high-angle reverse movement pattern.

A search of the literature revealed no antecedents for the strain pattern postulated here, termed apparent constriction fracture flow. The work by Gapais and others (1987, p. 645 and Fig. 9) gives theoretical support to the concepts advanced above: "The constriction field is expected to yield rod-shaped shear zone patterns." Those patterns (see Fig. 45) do indeed apply in the Sunshine fracture array, although fracture density is low. These same authors point out ( $p$. 635) that ". . . shear zone patterns can be used to estimate both a bulk finite strain ellipsoid and aspects of the bulk deformation history." From Fig. 38, we postulate a flattened prolate spheroid for the bulk strain ellipsoid in the veins of the Sunshine mine; its steep axis lies in the slip line. But note again that non-homogeneous strain allows both reverse and normal vein slip at different places synchronously during mineralization. From the descriptions above, both reverse and normal movements occurred at different places during mineralization, although reverse movements are dominant. As suggested elsewhere in this paper, and supported by the presence of pinch-and-swell features in the veins, a small component of bulk flattening may affect the rocks late during vein development; the boudined veins can be explained in that way.

Siderite was introduced early in the Sunshine veins, and tetrahedrite came later. The siderite was deposited as filling in open space, shown by relics of crustification fabric. The openings appear to be due to refraction phenomena (Reid and others, 1975). An example is taken from the Copper vein. It cuts $80^{\circ}$-south-dipping beds, dipping $55^{\circ} \mathrm{S}$ in quartzite and $69^{\circ}$ in argillite at a representative point of observation. Thus the vein in passing from argillite to quartzite is deflected toward the normal to the interface; high-angle reverse movement opens the fracture for filling in quartzite. In argillite, the

fracture is narrow and not mineralized. Refraction relations are no doubt complicated by the probability that the mine lies in a deltaic transition zone where quartzite and argillite interfinger irregularly.

Tetrahedrite ore shoots are elongate within the veins, with a steep westerly rake. Tetrahedrite-siderite fabrics strongly suggest a history involving shear and brecciation, with tetrahedrite deposited perhaps by a combination of filling and replacement. Ore shoots are distributed at intervals along the siderite veins, independent of vein intersections, which are generally occupied by barren siderite.

Ore shoots elongate along the slip line shown by slickenlines and grooving suggests their development during continuing slip but in localized slip zones. These movements caused brecciation of the siderite and are responsible for ore shoot elongation in the slip line. 
The localized slip zones are taken as controlled by subordinate shears of the axial array (see Fig. 38) that stand at high angles to the dominant but average $\mathrm{N} 90 \mathrm{E}$ trend. These $\mathrm{Elip}$ zones are tear-fault analogs. Differential slip along the "tears" in the walls generated local zones of brecciation, permitting tetrahedrite deposition in ore shoots elongate in the slip line.

A more-general question on vein development is why the dominant N9OE trend? This trend bears no obvious relation to the N65W trend of the TEZ, to the N75-80W trend of the Osburn fault, to average bedding, or to average cleavage ( $N 75 \mathrm{~W} 71 \mathrm{SW}$ ). Thus the semi-ductile flow implicit in the apparent constriction flow model is truly passive, relating to the operative stress field. That may well derive from the resolved thrust component of the Wallowa-Seven Devils block movemente from farther south, if, of course, the strain is of Mesozoic age.

Earlier, we suggested that cleavage in the Sunshine domain was produced during dip-slip, ductile movements of high-angle reverse nature. Also suggested earliex is the development of faults of $\mathrm{D} 2 \mathrm{c}$ during movemente dominantly of high-angle reverse nature. Above, we also suggested vein development under semiductile conditions in apparent constriction fracture flow, during essentially dip-elip movements of high-angle reverse type. The mechanical similarity among the three features is notable and suggests a kind of strain continuity in which the rheology changes from ductile toward the ductile-brittle transition. The only substantial difference is in trend: cleavage at $N 75 \mathrm{~W}$, faults at $\mathrm{N} 55 \mathrm{~W}$, and veins at $\mathrm{N} 90 \mathrm{~W}$. The trend differences may be related to minor inconstancies in the largely uniaxial stress field through time.

It is notable that few strike-slip slickenlines or grooves overprint vein features in the Sunshine system. Therefore, the faults/veins therein were not generally reactivated during movements in the Osburn fault. White (1989) showed that such features are present in the Lucky Friday mine, which lies near the Osburn fault.

\section{District-wide Phenomena}

Extrapolating from the above discussion, mineralization in

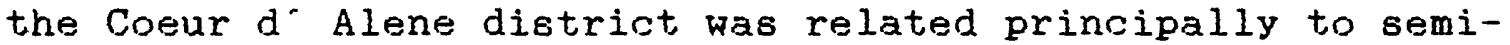
ductile, reverse-fault deformation, with a small sinistral component; this is supported by Fryklund's observation (1964, $\mathrm{p}$. 61), following that of Ransome and Calkins (1908, p. 125), that most ore shoots rake between $70^{\circ}$ and $90^{\circ}$ in the plane of the vein. This is seen also, as remarked above, in mine longsections from the district. Moreover, Fryklund noted (1964, $p$. 64 ) that ore shoote occur both in steeper- and in shallowerdipping vein segments at different places. This clearly implies both normal and reverse dip-slip components in what may generally have been an oblique-slip milieu. Descriptive material above, from the Sunshine mine, is consistent with this; further, some ore shoots there have horizontal elongation, indicating little or no strike-slip component of slip during mineralization. These observations in large part suggest little stress reorganization 
and little change in strain type following regional cleavage development during ductile reverse faulting. This is consistent with material from Rerr and Robinson (1953), showing early pyrite-uraninite veins partly controlled by cleavage-parallel fractures and cut by later siderite-tetrahedrite veins. In spite of the strong linear trend of the mineral belts (Fig. 1), vein orientations within them are somewhat diverse. Thus, a complex movement history is suggested. Caddey, 1974, p. 232-235, in a study at the Bunker Hill mine (Fig. 1), demonstrated introduction of sulfides during early dextral slip, followed by further sulfides derived perhaps by mobilization of early sulfides, deposited during later sinistral slip; the sequence then followed by normal faulting. Reid and others, 1975, showed refraction effects of sinistral slip during mineralization.

Described above, the mineral belts of the Coeur d' Alene district show strong relations to the TEZ, being symmetrically disposed across it (Fig. 1). Those north and south of it (set 1) are subparallel to the TEZ trend, whereas those within it (set 2 ) lie at more northerly trends.

The mineral belts of set 1 (Fig. 48) contain a dominant vein set oriented N7DW 70SW. A weaker set is oriented N75E 6OSE. These two sets are near $30^{\circ}$ apart. Utilizing the hypothesis of brittle fracturing applied by earlier workers for the origin of the veins in set 1 , a shear set, (N7OW) and an extension fracture set (N75E) are present (the plane parallel to the mineral belt trend is assumed to be the shear plane). The movement solution shows sinistral-reverse oblique slip, with the strike-slip component dominant (slip line is 22 N78W) and implying slickenlines dominantly in or near the strike line. This is all inconsistent, with the movement solution arrived at for the Sunshine veins, shown to be generated during semi-ductile fracture flow. The apparent constriction fracture flow hypothesis may apply over part or all of the Coeur $d^{-}$Alene district. The data set from Fryklund (1964) is small and perhaps statistically invalid; however (see Fig. 48), the two sets intersect near the dip line. This tends to support the model based on apparent constriction fracture flow.

The mineral belts of set 2 (Fig. 49) contain a dominant vein set oriented N7OW $75 \mathrm{SW}$, near parallel to the TEZ but lying within mineral belts of N6OW trend. A weaker set is oriented N67W $80 \mathrm{NE}$. These two sets are near $30^{\circ}$ apart. Utilizing the hypothesis of brittle fracturing for their origin, a shear set, (N7OW) and an extension fracture set (N67W) are present (the same shear plane as in set 1 is chosen here as well). The movement solution shows normal-dextral oblique slip, with the dip slip component dominant (slip line $73 \mathrm{~s} 46 \mathrm{~W}$ ). Note that the alternative brittle fracture solution involves dominant high-angle reverse slip. Because of the small data set, these conclusions are preliminary at best. Note also that because these two vein sets intersect in the strike line, the hypothesis of apparent constriction fracture flow is not applicable for rocks within the TEZ.

The existence of veins of N7OW trend, parallel to the TEZ trend, within mineral belts of N6OW trend, presents a problem. The pattern in plan projection is that of mineral belts in a Riedel shear array (see, e.g., Tchalenko, 1970) showing a 
component of dextral slip; this pattern is consistent with the component of dextral slip shown in the proposed movement

solution. Perhaps earlier shears like those of the N70W set in mineral belt set 1 have been differentially reactivated in en echelon arrays governed by large but weak Riedel shear sets.

In general, the vein patterns in the two sets of mineral belts show different fracture sets. These sets experienced movements along similar slip lines but in different strain regimes; one perhaps dominantly in semi-ductile reverse slip and the other perhaps dominantly in brittle normal dip slip with a small dextral component. Therefore, the response of rocks to regional stress within and without the TFZ is different. It seems likely that this is a function of different strain histories in two environments, one inside a zone of ductile transcurrent faulting and the other outside that zone, where ductile, dominantly reverse slip occurred.

This pattern of differential veining in rocks of different strain histories has been encountered once before by the senior author, at the Homestake mine, Lead, South Dakota, U.S.A. There, late-stage quartz veining associated with gold mineralization shows different patterns in two environments. In mylonite zones up to $1 \mathrm{~km}$ wide, quartz veins are arrayed in patterns indicative of biaxial normal faulting of brittle character. In schist country rock outside the mylonite zones, quartz veins are arrayed in patterns indicating uniaxial normal faulting of brittle character. Detailed reasons for the responses in both the Homestake mine and the Coeur $d^{-}$Alene district remain elusive, although strain hardening may have occurred in the TFZ.

\section{General Interpretations}

Leach and others (1988) showed that the mineralization is due to the migration of metamorphic fluids into and along fracture systems, bringing metals from the wall rocks in a process that may be characterized as metamorphic lateral secretion; this does not seem wholly consistent with semi-ductile to brittle fractiure in the vein-controlling faults. Perhaps the fluids are of deeper derivation than the level at which the ore deposits formed. Evidently, the folding and metamorphism are broadly coincident, and so are the metamorphism and the mineralization. Because the mineral belts bracket the TFZ (Fig. 1), we suggest that the TFZ was the dominant channel for mineralizing fluids.

It is notable that mineral belts trend about $\mathrm{N} 65 \mathrm{~W}$, independent of and crossing some cleavage trends. Thus, latestage fracturing was not strongly influenced by earlier ductile trends, including folds and their joints as well. If these features are parallel or sub-parallel in places, it appears to be somewhat accidental, although regional trend similarities still exist. Folds clearly formed and experienced rotation and some translational faulting prior to cleavage and then mineral belt development. The mineral belts have experienced no evident rotation subsequent to their development, but only translation. Thus, the fold rotation must be pre-Laramide. 
One possible idea for the postulated movement scheme is through transform movement in the Lewis and Clark line during mineralization. Therefore, early dextral movement was followed by later sinistral movement as first the north wall and then south wall (or vice versa) advanced more quickly during a single movement event. More complex and less likely would be a scheme involving dextral slip, followed closely in time by sinistral slip; all during the main stage of mineralization. A major stress reorientation would be required.

Alternately, it seems possible, as mentioned above, that the faults developed in a bulk flattening mode in brittle or semibrittle strain. Here, both right and left slip, both normal and reverse slip, and various combinations of oblique slip might occur synchronously at. various points in the rock. The strese would be near-horizontal in NNE, continuing the deformation begun during cleavage development and in the same general strain event; only the strain type changed.

Yet another idea is suggested by the target-shaped pattern of the restored Coeur $d^{\prime}$ Alene district (Bennett and Venkatakrishnan, 1982); that pattern, combined with the multiplicity of movements in various vein sets, gives the impression of irregular jostling of crustal blocks in the target area. This is a pattern that might develop over the roof of a deep intrusion. If the intrusion were synkinematic and synmetamorphic, the existing pattern might be best explained. The metamorphic fluids suggested by Leach and others (1988) as involved in the metamorphism and related ore deposition may have been driven from depth by igneous energy. Regional metamorphic fluids and contained metals rising through their own agency might be expressed along the fault zone for a considerable distance in which case the (restored) target pattern wolld not be expected, but a more linear one.

Einally, and perhaps best, eastward slip of the Wallowa terrane, discussed above, may generate the thrust movements that seem to dominate vein development. Again, the eastward movement, of the Wallowa terrane, oblique to the ESE trend of the Lewis and Clark line, generated a component of thrusting in the Lewis and Clark line.

Dating of the age of mineralization at about $825 \mathrm{Ma}$ (Harrison and others, 1974, p. 11) provides an estimate of the age of the faulting and places it broadly and presumably late in the Goat River orogeny (McMechan and Price, 1982, p. 476), D2 in the regional structural sequence. Another estimate of oredeposit age is $825 \mathrm{Ma}$ (Zartman and Stacey, 1971, p. 853). Erom geologic evidence, however, a different picture emerges. The mine geology map published by Umpleby and Jones (1923, Eig. 2) shows base metal veins cutting monzonite in the eastern Coeur $d$. Alene district. Thus, the metallization is younger than the monzonite, which has been dated as late Cretaceous (Larsen and others, 1958). A comparable young age for igneous activity has been suggested on other grounds by Criss and Fleck, 1990, p. 649651. The late Cretaceous mineralization age determined by Fleck and others ( 1991 ) reinforces this view, which is consistent with the geologic evidence. This suggeste that much or all of D2 is of late Cretaceous age and that Cretaceous tectonic, igneous, and 
metamorphic processes provide the best possibilities to explain the mineral deposits and their tectonic framework. The late Precambrian isotope ages apparently require re-evaluation..

Post-ore Normal Faulting

Closing out this section, we consider the origin of the rather abundant post-ore faults, exemplified in the fault data from the Sunshine mine. The small-circle girdle of fault poles in Figure 63 suggests a conical array of normal faults developed in a field of near-vertical uniaxial stress, such as might develop in the roof of an intrusive body. This pattern was earlier discerned by the senior author during work in the Bunker Hill mine in 1975 , studying post-ore normal faults. The suggestion at that time was one of near-vertical uniaxial stress, an idea that still seems valid. It is a question whether these normal faults pre-date or post-date the transcurrent Laramide movements in the district. We suggest that they belong to latestage movements in the roof of the intrusion that was primarily responsible for generating the ore bodies in the district. Laterecurring movement would be implied. However, if the orebodies are Precambrian, then this was a post-ore intrusion, and a different origin for the vertical, uniaxial stress field would have to be sought.

\section{Other Eaulting}

Mesozoic thrusting, but pre-Cretaceous, has affected the Belt rocks of the region (Harrison and others, 1974), which moved northeast on a detachment surface perhaps partly on basement rocks in the west and on Paleozoic rocks farther east; detailed effects are far from prominent in the Coeur d' Alene district. If the rocks of the Coeur $d$ " Alene region were affected by such movemente, as seeme likely, given their position just east of the Eocene Spokane dome metamorphic core complex, then the whole Lewis and Clark line set of structures may have been detached from its roots and moved to the northeast by some distance. Laramide reactivation or generation of the Osburn fault resulted in strike-slip movement which was perhaps rooted in the detachment surface on the crystallines. In this way, perhaps, we may see why the Lewis and Clark line structures do not extend into the spokane dome. Broad speculation raises the possibility that the Olympic-Wallowa lineament represents the former continuation of the Lewis and Clark line, particularly in view of the work by Eisbacher, 1983, showing large sinistral shear in the Purcell lireament.

The Laramide Osburn faulting and movement on other faults formed in or reactivated in the same event is characterized here as D3; Hobbs and others $(1965, \mathrm{p} .12)$ showed that the "major portion of the strike-slip faulting occurred some time after the intrusion of the monzonitic stocks, which are Cretaceous in age, and prior to the outpouring of the Columbia River Basalt, which occurred in Miocene time." The Osburn fault zone is filled with gouge indicative of brittle deformation, showing strain at much 
lower $P, T$ than that which obtained during mineralization. Moreover, sulfide vein fillings are extensively deformed and original fabrics destroyed in post-mineral falut movement (see, e.g., Caddey, 1974; and Siems, 1973.

\section{Joints}

A major objective in the present investigation has been to gain a fuller understanding of joint development both in folds and along faults, to see if it showed any relation to controls of mineralization. Several workers explored this question. A further question has to do with the relative ages of joint and cleavage development. Although different workers estimate joints to develop with folds, with faults, with both, or to post-date all such events, no paper that we read except the one discussed below offers observations as to whether joints cut cleavage or cleavage cuts joints.

The most definitive analysis is that by Venkatakrishnan (1984). He carried out a detailed analysis of one area, in the Big Creek anticline, a major north-overturned fold lying south of the Osburn fault and nearly parallel to it. His 134-page treatise (unpublished) is briefly summarized here. The purpose is to investigate whether there exists a systematic pattern of joints that characterizes the folds in the area and whether these joints can be distinguished from possible regional sets.

Joint plane orientations were recorded at 43 sample points, totaling some 2755 measurements. At most locations, four principal sets, J1 to J4, could be distinguished, orthogonally oriented to the bedding plane. $J 1$ is at about $90^{\circ}$ to the bedding strike, whereas J2 parallels the strike. J3 and J4 are more or less orthogonal to each other and oblique to J1 and J2. Four other sets, J5 to J8, are oblique to bedding and to the strike; generally terminated by $J 1$ to $J 4$ and lying in the overturned $1 \mathrm{imb}$ of the fold, they are evidently late and related to fold

overturning.

The results of the study indicate that sets J1 to J4 were probably formed prior to D2 folding as orthogonal sets, very much in the same way as described by Price (1966). The Big Creek anticline is approximately cylindrical about a mean fold axis of 10 290. Set J1 corresponds to the ac-joint of Price (1966), and J2 to the bc-joint. Sets J3 and J4 are oblique to the fold axis and correspond to the cross-joints of Price (1966). Thus, the joint sets are clearly geometrically related to the regional Big Creek anticline. The joints maintain orthogonal relations to the bedding plane, similar to those observed by Friedman and Stearns, 1972. Both sets, then, display orientations corresponding to joints developed in tension. Their $90^{\circ}$ dihedral angles do not correspond to the approximately $60^{\circ}$ angles associated with shear joints developed in brittle strain. Joints are likely to indicate the orientation of the stress field at one instant in geologic time (Bankwitz, 1966). Field evidence shows that flow cleavage cuts the joint set $J 1$. Thus, the joints developed early. A mechanism for early, deep formation of joints is by hydraulic failure as a result of pore-fluid pressure during lithification and folding (Secor, 1965). Of course, substantial 
dewatering must already have occurred during the D1 metamorphism. This leads to the suggestion that, J1 to J4 formed in a tensile regime, consistent with early flattening strain postulated above. Once formed (in early D2--they are symmetrical on F2), the joints were able to survive rotation during moderate folding and metamorphism transitional into the greenschist facies. This joint development pre-dates mineralization, occurring, as it does, early in the folding deformation, which is itself of premineralization age. This view of the jointing is consistent with Fryklund's remark, quoted above, that mineralization is not influenced by fold-related joints. It is possible, if not probable, that this scheme is applicable to early joint development across the Coeur $d^{*}$ Alene district. Of course, such features may well have been obliterated or at least strongly modified in zones of intense ductile strain such as the TEZ. In spite of the convincing character of the Venkatakrishnan analyeis for a small area, joint data for a broader area, such as the 7.5-minute quadrangle within which the Venkatakrishnan study lies (see Fig. 66), shows wide-ranging strikes and mostly steep dips. The 3\% trend, near $\mathrm{N} 15 \mathrm{E} 90$, hardly a dominant one, is related to no fold or cleavage trend. If early joints were substantially rotated with the bedding in folds, more shallow dips should be present. Thus, Figure 66 allows the inference that the broader problems of joint origin and timing remain unresolved at the current level of analysis. This figure is remarkably similar to one compiled by Campo, 1984, Fig. 16, for joints in rocks north of the Osburn fault. More than one age of joint development may have occurred.

\section{GUIDES TO MINERAL EXPLORATION}

A comment by Fryklund (1964, p. 66) merits re-emphasis with respect to mineral exploration: "Unexplored parts of the mineral belts hold the greatest promise for the discovery of new mines." Our further suggestion is that exploration in the plunge direction steep to the southwest holds the greatest promise of future discoveries.

\section{REFERENCES CITED}

Anderson, E.M., 1951, The dynamics of faulting, $2 d$ ed.: Oliver and Boyd, Edirburgh, $206 \mathrm{p}$.

Anderson, M.A., 1991, The geology and structural analysis of the Tomer Butte, Middle Potlatch Creek and Little Potlatch Creek area, Latah County, Idaho: Unpublished M.S. Thesis, Oniversity of Idaho, Moscow, Idaho, $69 \mathrm{p}$.

Armstrong, R.L., Taubeneck, W.H., and Hales, P.O., 1977, Rb-Sr and $\mathrm{K}$-Ar geochronometry of Mesozoic granitic rocks and their $\mathrm{Sr}$ isotopic composition, Oregon, Washington, and Idaho: Geological Society of America Bulletin 88, p. 397-411. 


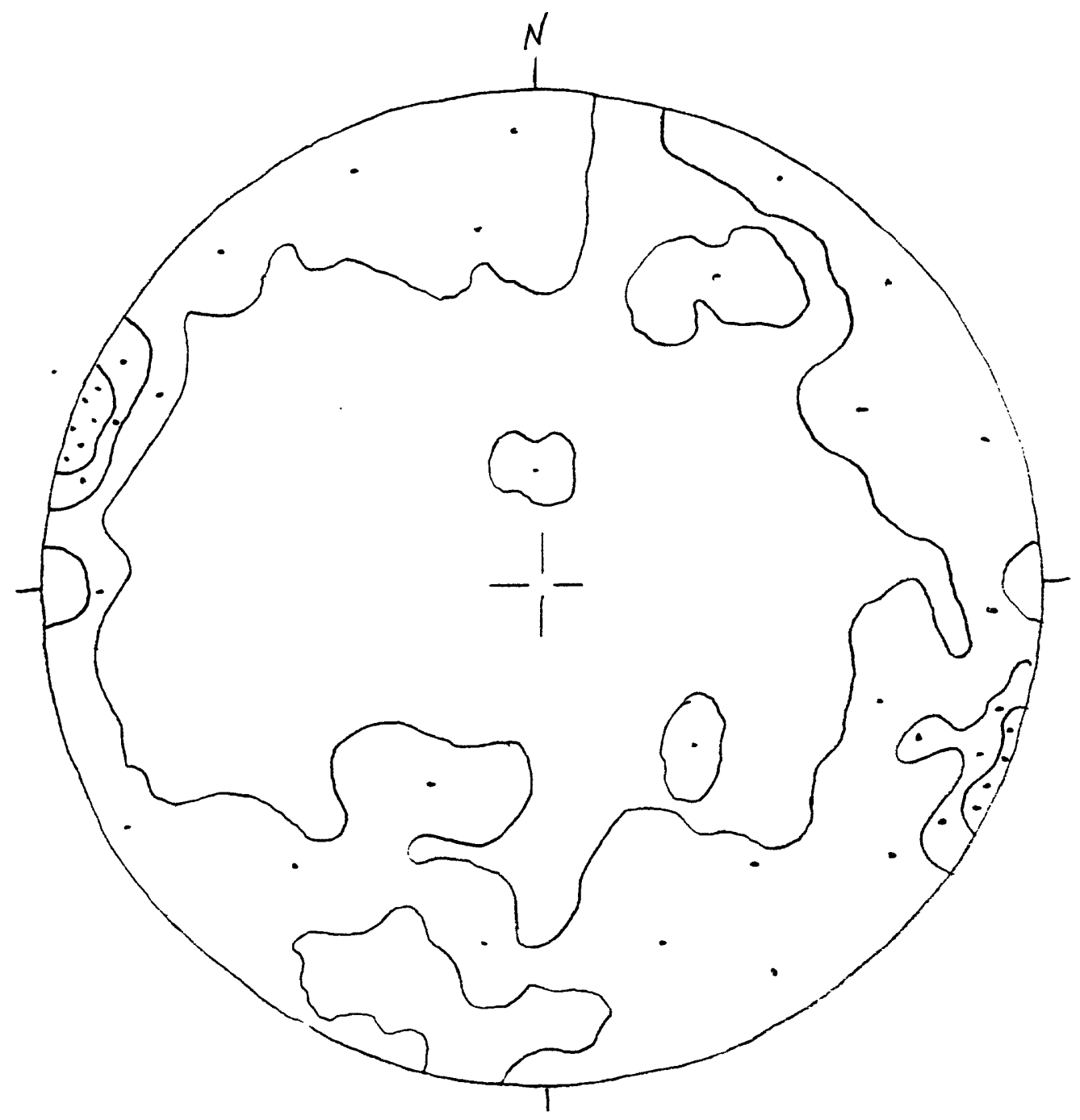

Eigure 66. PI diagram, joints, Sunshine subarea, Coeur d Alene district, Idaho. $\mathrm{N}=852$. Contours $1,2,3 \%$ per $1 \%$ area. Schmidt, net, lower hemisphere. 
Bankwitz, V.P., 1966, Die Bildung der Kluftfluche und eine Systematic ihrer strukturen uber Kluft: Geology, v. 15, p. 896941 (translation in English: abstract).

Bennett, E.H., and Venkatakrishnan, R., 1982, A palinspastic reconstruction of the Coeur $d^{-}$Alene mining district based on ore deposits and structural data: Economic Geology, v. 77, p. 18511866 .

Berthe, D., Choukroune, P., and Jegouzo, P., 1979, Orthogneiss, mylonite, and non coaxial deformation of granitee: the example of the South Armorican shear zone: Journal of Structural Geology, $v$. 1 , p. $31-42$.

Billingsley, P.R., and Locke, A., 1939, Structure of ore deposite in the continental framework: American Institute of Mining and Metallurgical Engineers, New York, 51 p.

Bishop, D.T., 1973, Petrology and geochemistry of the Purcell sills in Boundary County, Idaho: in Idaho Bureau of Mines and Geology Special Report 3: Belt Symposium, v. 2, p. 15-66.

Caddey, S.W., 1974, Structural geometry of the "J" vein, the Bunker $\mathrm{Hill}$ mine, Kellogg, Idaho: Unpublished Ph.D. Dissertation, University of Idaho, Moscow, Idaho, $352 \mathrm{p}$.

Campbe11, A.B., 1960, Geology and mineral deposits of the St. Regis-Superior area, Mineral County, Montana: U.S. Geol. Survey Bulletin 1082-I, p. 545-612.

Campo, A.M., 1984, Geology and structural analysis of the SE $1 / 4$ of the Burke 15 quadrangle, Shoshone County, Idaho: Unpublished M.S. Thesis, University of Idaho, Moscow, Idaho, $190 \mathrm{p}$.

Clark, B.R., 1970, Origin of slaty cleavage in the Coeur d' Alene district, Idaho: Geological Society of America Bulletin, v. 81 , p. 3061-3072.

Clough, A.H., 1981, Geology of the NE $1 / 4$ of the Calder quadrangle, Shoshone County, Idaho: Unpublished M.S. Thesis, University of Idaho, Moscow, Idaho, $105 \mathrm{p}$.

Colson, J.B., 1961, The geology of the Sunshine mine: in Reid, R.R., ed., Guidebook to the Geology of the Coeur d'Alene Mining District, Idaho Bureau of Mines and Geology Bulletin 16, p. 3037 .

Coney, P.J., 1989, Structural aspects of suspect terranes and accretionaly tectonics in western North America: Journal of Structural Geology, v. 11, p. 107-125.

Constantopoulos, J.T., 1989, Oxygen and hydrogen isotope geochemistry of the Coeur $d^{\prime}$ Alene mining district, Idaho: Unpublished $\mathrm{Ph}$. D. thesis, University of Idaho, Moscow, Idaho. 
Criss, R.E., and Fleck, R.J., 1987, Petrogenesis, geochronology, and hydrothermal systems $8 f$ the northerf Idaho batholith and adjacept areas based on ${ }^{18} \mathrm{O} /{ }^{16} \mathrm{O}, \mathrm{D} / \mathrm{H},{ }^{87} \mathrm{Sr} /{ }^{86} \mathrm{Sr}, \mathrm{K}-\mathrm{Ar}$, and $4 \mathrm{Ar} /{ }^{39} \mathrm{Ar}$ studies: in Geology of the Blue Mountains region of Oregon, Idaho, and Washington: The Idaho Batholith and its Border Zone, Tracy L. Vallier and Howard C. Brooks, eds., U.S.G.S. Profeseional Paper 1436, Ch. 6, p. 95-138.

Criss, R.E., and Fleck, R.J., 1990, Oxygen isotope map of the giant metamorphic-hydrothermal system around the northern part of the Idaho batholith, U.S.A.: Applied Geochemistry, v. 5, p. 641655 .

Eisbacher, G.H., 1983,. Devonian-Mississippian sinistral transcurrent faulting along the cratonal margin of western North America--An hypothesis: Geology, v. 11, p. 7-10.

Eslinger, E.V., and Sellars, B., 1981, Evidence for the formation of illite from smectite during burial metamorphism in the Belt Supergroup, Clark Fork, Idaho: Journal of Sedimentary Petrology, v. 51, p. $203-216$.

Evans, R.V., 1986, Middle Proterozoic deformation and plutonism in Idaho, Montana and British Columbia: in Montana Bureau of Mines and Geology, Special Publication 94, Sheila M. Roberts, Technical Editor, p. 237-244.

Eleck, R.J., and Gunn, S.H., 1991, The use of integrated geologic, geochemical, and isotopic studies in the identification and interpretation of lithospheric boundaries in the northwestern United States: Geological Society of America Abstracts with Programs, v. 23, p. A210.

Fleck, R.J., Criss, R.E., Eaton, G.F., Wavra, C.S., and Bond, W.D., 1991, Strontium and oxygen isotopic characteristics and the age of siderite tetrahedrite veins in the Sunshine mine, Coeur $d^{-}$ Alene district, Idaho: Geological Society of America Abstracts With Programs, v. 23, no. 5, p. A173.

Foster, S.A., 1983, Structural analysis of the NE $1 / 4$ of the Wallace $15^{-}$quadrangle, Shoshone County, Idaho: Unpublished M.S. Thesis, University of Idaho, Moscow, Idaho, $150 \mathrm{p}$.

Friedman, M., and Stearnes, D.W., 1971, Relations between stresses inferred from calcite twin lamellae and macrofractures, Teton anticline: Geological Society of America Bulletin, v. 82, p. 3151-3162.

Fryklund, V.C., Jr., 1964, Ore deposits of the Coeur d' Alene district: U.S. Geological Survey Professional Paper 445, 103 p.

Gapais, D., Bale, P., Choukroune, P., Cobbold, P.R., Mahjoub, Y., and Marquer, D., 1987, Bulk kinematics from shear zone patterns: some field examples: Journal of Structural Geology, v. 9, no. 5/6, p. 635-646. 
Gresseth, E.W., and Reid, R.R., 1968, A petrofabric study of tectonic and mining-induced deformations in a deep mine: U.S. Bureau of Mines Report of Investigations $7173,64 \mathrm{p}$.

Harrison, J.E., Kleinkopf, M.D., and Obradovich, J.D., 1972, Tectonic events at the intersection between the Hope faldt and the Purcell Trench, northern Idaho: U.S. Geological Survey Profeseional Paper 719, 24 p.

Harrison, J.E., Griggs, A.B., and Welle, J.D., 1974, Tectonic features of the Precambrian Belt basin and their influence on post-Belt structures: U.S. Geological Survey Professional Paper $866,15 \mathrm{p}$.

Hayden, T.R., 1992, Structural geology of the western part of the Coeur $d^{\prime}$ Alene mining district, Idaho: Unpublished Ph.D. thesis, University of Idaho, Moscow, Idaho, p.

Hershey, O.H., 1916, Origin and distribution of ore in the Coeur $d^{*}$ Alenes: Private Publication, San Erancisco, Mining and Soientific Press, 32 p.

Hobbs, S.W., Griggs, A.B., Wallace, R.E., and Campbell, A.B., 1965, Geology of the Coeur $d^{-}$Alene district, Shoshone County, Idaho: U.S. Geological Survey Professional Paper 478, 139 p.

Husman, R.J., 1989, Structural geology of the Sunshine mine with special emphasis on the formation of the "Hook area" veins, Coeur

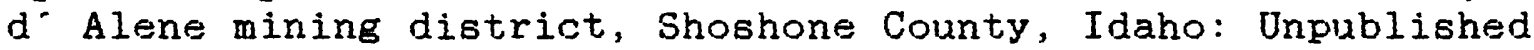
M.S. Thesis, University of Idaho, Moscow, Idaho, $71 \mathrm{p}$.

Jones, D.L., Silberling, N.J., and Hillhouse, J., 1977 , Wrangellia--a displaced terrane in northwestern North America: Canadian Journal of Earth Sciences, v. 14, p. 2565-2577.

Kerr, P.E., and Robinson, R.F., 1953, Uranium mineralization in the Sunshine mine, Idaho: Mining Engineering, v. 5, no. 5, p. 495-511.

Larsen, E.S., Jr., Gottfried, D., Jaffe, H.W., and Waring, C.L., 1958, Lead-alpha ages of the Mesozoic batholiths of western North America: U.S. Geological Survey Bulletin 1070-B, p. 34-63.

Leach, D.L., Landis, G.P., and Hofstra, A.H., 1988, Metamorphic origin of the Coeur $d^{\prime}$ Alene base- and precious-metal veins in the Belt basin, Idaho and Montana: Geology, v. 16, p. 122-125.

Lindgren, Waldemar, 1904, A geological reconnaiseance across the Bitterroot Mountains in Montana and Idaho: U.S. Geological Survey Professional paper $27,123 \mathrm{p}$.

Mathewson, D.C., 1972, Structures related to the Osburn fault, Coeur $d^{-}$Alene mining district, Shoshone County, Idaho:

Unpublished M.S. Thesis, University of Idaho, Moscow, Idaho, 150 
p.

Maxwe11, D., and Hower, J., 1967, High-grade diagenesie and lowgrade metamorphiem of illite in the Precambrian Belt Series: American Mineralogist, v. 52, p. 843-857.

McMechan, M.E., and Price, R.A., 1982, Superimpoeed low-grade metamorphism in the Mount Fisher area, southeastern British Columbia--implicatione for the East Kootenay orogeny: Canadian Journal of Earth Science, v. 19, p. 476-487.

Miller, M.M., 1987, Dispersed remnants of a northeast Pacific fringing arc: Upper Paleozoic terranes of Permian McCloud faunal affinity, western U.S.: Tectonice, v. 6, 807-839,

Moody, J.D., and Hill, M.J., 1956, Wrench-fault tectonice:

Geological Society of America Bulletin, v. 67, p. 1207-1246.

Mortimer, N., 1986, Late Triassic, arc-related, potaseic igneous rocks in the North American Cordillera: Geology, v. 14, p. 10351038 .

Obradovich, J.D., and Peterman, Z.E., 1968, Geochronology of the Belt Series, Montana: Canadian Journal of Earth Science, v. 5, p. 737-747.

Pollard, D.D., Segall, P., and Delaney, P.T., 1982, Formation and interpretation of dilatant echelon cracks: Geological Society of America Bulletin, v. 93, p. 1291-1303.

Price, N.J., 1966, Fault and joint development in brittle and eemi-brittle rock: Pergamon Prees, New York, 976 p.

Price, R.A., 1979, Intracontinental ductile spreading linking the Fraeer River and northern Rocky Mountain Trench transform fault, zones, south-central British Columbia and northeaet Washington: Geological Society of America Abstracts with Programe, v. 11, no. 7, p. 499 .

Ramsay, J.G., 1967, Eolding and fracturing of rocks: McGraw-Hill Book Company, New York, $568 \mathrm{p}$.

Ramsay, J.G., and Huber, M.I., 1983, The techniques of modern etructural geology, v. 1, strain analysis: Academic Preet, 307 p.

Ransome, F.L., 1905, Geology and ore depoeite of the Coeur d' Alene district, Idaho: U.S. Geological Survey Bulletin 260, p. 274-303.

Raneome, F.L., and Calkins, F.C., 1908, Geology and ore depoeits of the Coeur d' Alene district, Idaho: U.S. Geological Survey Professional Paper 62, 203 p.

Rehrig, W.A., and Reynolde, S.J., 1981, Eocene metamorphic core complex tectonics near the Lewis and Clark zone, western Montana 
and northern Idaho: Geological Society of America Abstracts with Programs, v. 13, no. 2, p. 102.

Reid, R.R., 1984, Structural control of the Coeur d' Alene ore deposits: in Hobbs, S.W., ed., The Belt, Abstracts with

Summaries, Belt Symposium II: Montana Bureau of Mines and Geology Special Publication 90, p. 49-50.

Reid, R.R., Caddey, S.W., and Rankin, J.W., 1975, Primary refraction control of ore shoots, with examples from the Coeur $d^{\text {. }}$ Alene district, Idaho: Economic Geology, v. 70, p. 1050-1061.

Reid, R.R., and Greenwood, W.R., 1968, Multiple deformation and associated progressive polymetamorphism in the Beltian rocks north of the Idaho batholith, Idaho, U.S.A., in Proceedings, XXII International Geologic Congress, v. 4: Prague, Czeckoslovakia, p. $75-87$.

Reid, R.R., Morrison, D.A., and Greenwood, W.R., 1973, The Clearwater orogenic zone: a relict of Proterozoic orogeny in central and northern Idaho, in Belt Symposium 1973: Department of Geology, University of Idaho and Idaho Bureau of Mines and Geology, v. 1, p. 10-56.

Reid, R.R., Greenwood, W.R., and Nord, G.L., Jr., 1981 , Metamorphic petrology and structure of the St. Joe area, Idaho: Geological Society of America Bulletin, v. 92, part II, p. 94205 .

Reid, R.R., Wavra, C.S., and Bond, W.D., 1992, Apparent constriction fracture flow: A suggested mechanism for fault and vein formation, with examples from the Coeur d' Alene district, Idaho: Geological Society of America Abstracts with Programs, $v$. 24 , no. 7 , p. A148.

Scholz, C.H., 1990, The mechanics of earthquakes and faulting: Cambridge Univereity Prese, New York, 439 p.

Secor, D.T., 1965, Role of fluid pressure in jointing: American Journal of Science, v. 263, p. 633-646.

Seyfert, C.K., 1984, The Clearwater core-complex: A new Cordilleran metamorphic core complex and its relation to a major continental transform fault: Geological Society of America Abstracts with Programs, v. 16, no. 6, p. 651 .

Shenon, P.J., and McConnel, R.H., 1940, Use of sedimentary features and cleavage in the recognition of overturned strata: Economic Geology, v. 35, no. 5, p. 430-444.

Sheriff, S.D., Sears, J.W., and Moore, J.N., 1984, Montana's Lewis and Clark fault zone: An intracratonic transform fault system: Geological Society of America Abstracts with Programs, $v$. 16 , no. 6, p. 653 . 
Siems, P.L., 1973, Deformational textures in ore bodies of the Coeur $d$ ' Alene mining district: Geological Society of America Abstracts with Programs, v. 5, no. 6, p. 513.

Skjernaa, L., 1989, Tubular folds and sheath folds: definition and conceptual models for their development, with examples from the Grapesvare area, northern Sweden: Journal of Structural Geology, v. 11, no. 6, p. 689-703.

Sorenson, A.H., 1989, Age and mode of origin of the Coeur d' Alene ore deposits, Idaho: Carlton Press, Inc., $85 \mathrm{p}$.

Strayer, L.M. IV, Hyndman, D.W., and Sears, J.W., 1989, Direction and shear sense during suturing of the Seven Devile-Wallowa terrane against North America in western Idaho: Geology, v. 17, p. 1025-1028.

Tchalenko, J.S., 1970, Similarities between shear zones of different magnitudes: Geological Society of America Bulletin, $v$. 81 , p. 1625-1640.

Theriault, B.D., 1989, Geology, alteration, and mineralization at the Atlas mine, Coeur $d$ ' Alene mining district, Shoshone County, Idaho: Unpublished M.S. Thesis, Washington State University, Pullman, Washington, 137 p.

Umpleby, J.B., and Jones, E.L., 1923, Geology and ore deposits of Shoshone County, Idaho: U.S. Geological Survey Bulletin 732, 156 p.

Vance, R.B., 1981, Geology of the NW $1 / 4$ of the Wallace $1^{\circ}$ quadrangle, Shoshone County, Idaho: Unpublished M.S. Thesis, University of Idaho, Moscow, Idaho, $103 \mathrm{p}$.

Venkatakrishnan, R., 1984, Fracture control of the Coeur d' Alene ore deposits, Shoshone County, Idaho: Unpidblished Report Submitted to the Idaho Geological Survey, 134 p.

Wallace, R.E., and Hosterman, J.W., 1956, Reconnaissance geology of western Mineral County, Montana: U.S. Geological Survey Bulletin 1027-M, p. 575-612.

White, B.G., 1989, Superposed map-scale folds and subsequent veins unrelated to Osburn strike-slip fault, Coeur d' Alene mining district, Shoshone County, Idaho (abs.): Geological Society of America, Abstracts with Programs, 21, 5, p. 158.

Willoughby, J.K., 1986, Geology of Prichard Formation and Ravalli Group rocks in the SE $1 / 4$ of the Kellogg $15^{\circ}$ quadrangle, Shoshone County, Idaho: Unpublished M.S. thesis, University of Idaho, Moscow, Idaho, $155 \mathrm{p}$.

Zartman, R.E., and Stacey, J.S., 1971, Lead isotopes and mineralization ages in Belt Supergroup rocks, northwestern Montana and northern Idaho: Economic Geology, v. 66, p. 849-860. 
Zartman, R.E., Peterman, Z.E., Obradovich, M.D., Gallego, M.D., and Bishop, D.T., 1982, Age of the Crossport C sill near Eastport, Idaho: in Society of Economic Geologists Field Conference, Idaho--1977: Idaho Bureau of Mines and Geology Bulletin 24, p. 61-70.

\section{APPENDIX 1. PRICHARD (KELLOGG) DATA SET}

Here are strikes and dips on bedding and cleavage. Each pair is believed to represent attitudes measured at single outcrops. Data are given in format acceptable to most, complaters.

\begin{tabular}{|c|c|c|c|c|c|}
\hline Bedding & Cleavage & Bedding & Cleavage & Bedding & Cleavag \\
\hline 39 W5OSW & N39W75SW & N47W65SW & N28W80SW & N45W35SW & $28 \mathrm{~h}$ \\
\hline N32W55SW & N24W7OSW & N15W50SW & N29W65SW & N10W50SW & C \\
\hline N15W60SW & N1OW50SW & NOOE5OW & NOOE 75 W & NO5W9ONE & 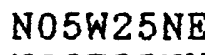 \\
\hline NOSE8OSE & NO5E65SE & N49E25NW & N10W75SW & $2 \mathrm{E} 55 \mathrm{NW}$ & \\
\hline NOOE $65 \mathrm{~W}$ & N3OW75SW & N28W50NE & N27W7 ONE & $20 \mathrm{NW}$ & \\
\hline 153E60NW & N79E55NW & W3 $5 \mathrm{NE}$ & N81W55NE & $O N W$ & \\
\hline ONE & N32W50NE & E 45NW & $30 \mathrm{NW}$ & ONW & \\
\hline $4 \mathrm{NW}$ & N33E40NW & N58E30NW & SONW & $5 \mathrm{NW}$ & \\
\hline OSW & N37W7DSW & NO4E3ONW & N1OE $15 \mathrm{NW}$ & $45 \mathrm{NW}$ & \\
\hline 55 W $60 \mathrm{NE}$ & N65W40NE & N47W6 $5 \mathrm{NE}$ & NO6W40NE & W6ONE & \\
\hline NO 4 W6 $6 \mathrm{NE}$ & NoOW35W & W75NE & N38E75NW & N69W60NE & \\
\hline 100E75E & N28W9ONE & E35NW & N72W55SW & N68W9DNE & \\
\hline $168 \mathrm{~W} 45 \mathrm{NE}$ & N36W90NE & $50 \mathrm{NW}$ & N48W6ONE & $3 W 30 \mathrm{SW}$ & \\
\hline N4 7 W7 ONE & N3OWB5SW & $45 \mathrm{NE}$ & ONE & $5 \mathrm{NE}$ & \\
\hline N55E70NW & N72E73NW & $40 N$ & N9 & OSE & \\
\hline N52W7 DNE & N24W80SW & W45NE & N4 4 W7 5 NE & ONE & \\
\hline N18W65SW & N40W85NE & E4ONW & N44E65NW & ONE & \\
\hline N8OW4ONE & N58W65NE & E8ONW & N25W9ONE & $5 \mathrm{NW}$ & \\
\hline N85W35NE & N70E35NW & N27E35NW & NOOW $45 \mathrm{~W}$ & $15 \mathrm{NW}$ & \\
\hline N30E25NW & NOOW $35 \mathrm{~W}$ & N45E05NW & OSW & $50 \mathrm{NW}$ & \\
\hline N45E39NW & E38NW & $40 \mathrm{NE}$ & $5 \mathrm{NW}$ & $50 \mathrm{NW}$ & \\
\hline $30 \mathrm{NW}$ & $5 \mathrm{NE}$ & $5 \mathrm{NW}$ & $5 \mathrm{NW}$ & & \\
\hline $5 \mathrm{NW}$ & NW & & SW & & \\
\hline N8 & NW & $\mathrm{N}$ & NW & NW & \\
\hline $55 \mathrm{NE}$ & $O N W$ & Ne & $\mathrm{NW}$ & $\mathrm{NE}$ & \\
\hline W $40 \mathrm{NE}$ & N52E $45 \mathrm{NW}$ & $5 \mathrm{NE}$ & N1 & $N E$ & \\
\hline N83W2 4NE & N45E40NW & $\sigma \mathrm{NE}$ & ONW & $40 \mathrm{NW}$ & \\
\hline N75E25NW & N3OE 40NW & E25NW & N3OE $45 \mathrm{NW}$ & N85E $40 \mathrm{NW}$ & \\
\hline & N22E $45 \mathrm{NW}$ & W $35 \mathrm{NE}$ & NoOW $35 \mathrm{~W}$ & N7 OE.3ONW & \\
\hline E35NW & N33E 40NW & N67E30NW & N33E4DNW & N55 & \\
\hline $\mathrm{E} 45 \mathrm{NW}$ & N75W55NE & N69E39NW & N43E 45NW & N8 4 W $35 \mathrm{NE}$ & N63E40 \\
\hline & & & & & \\
\hline
\end{tabular}




\section{APPENDIX 2. LOOKOUT ANTICLINE DATA SET}

Available map data here are different from those of Appendix 1 in that they do not show the detailed outcrop-by-outcrop correlation of bedding and cleavage attitudes.

\section{Bedding Attitudes}

\begin{abstract}
N65W57SW N59W85SW N2OW7DNE N73W59SW N77W58NE N80W62SW N72W47NE N55W8ONE N80W81NE N60E25SE N86E 4.3SE N87W60SW N80W5 $5 \mathrm{NE}$ N37E53SE N6 4E 18SE N47W4ONE N61W24SW N80W30SW N63W43SW N73E54NW N5 3W2ONE N54W82NE N81E55NW N61W40SW

N72W88SW N36E $10 \mathrm{NW}$ N58E29NW N75W68NE N55W7 1SW N38W04NE N6.3W83SW N77W81NE N47W4OSW N32E22SE N75W66SW N87W85NE N72W52NE N88W64SW N30E $12 \mathrm{NW}$ N68W39SW N75W6OSW N47W55SW N64W18SW N54W79SW N22W4OSW N36E $17 \mathrm{SE}$ N61W65NE N82W34NE
\end{abstract}

N57W83NE N59W9ONE N54W9ONE N76W90NE N57W58NE N68W85SW N54W41SW N52W9ONE N73W75SW N80W9ONE N83W70SW N69W55NE N89W60SW N90E90S N89W70SW N87W90SW
N85E75SE N7 0W90SW N82W80SW N55W9ONE N6 1W85NE N61W85NE N43W85NE N68W65SW N48W85SW N87W7DNE N40W9DSW N31W9DSW N43W9OSW N34W90SW N58W7 ONE N5OW9ONE

N58E14NW
N90E67S
N76W44NE
N85W45SW
N61W11SW
N80W32SW
N85W74SW
N55W32NE
N87E49SE
N35W68SW
N72W89NE
N40E23NW
N73E $44 S E$
N19W45SW
N80W10NE
N15W56NE
N48W45NE
N80W41SW
N84E27SE
N87E $35 \mathrm{NW}$
N80E $44 \mathrm{NW}$
N10E38NW
N68W25SW
N47W57NE

N76W27NE N87W35NE N78W8ONE N27W27 SW N66W60SW N76W55NE N75W64NE N8OW6DSE N63W43SW N77W35NE N10E 44NW N78W2ONE N2OW25SW N40W37NE N7 OW 45SW N72W56SW N53E37NW NO3E35SE N22W55SW N22E35NW N86W 45NE N83W40NE N58E22NW N77W71NE
N7 3W50NE N75W25NE N10W14SW N78W55SW N15E $28 \mathrm{NW}$ N38W49NE N8 1E5 1SE N40E $10 \mathrm{NW}$ N6OE 40SE N80W7 OSW N85E6 OSE NOOE $42 \mathrm{E}$ N52W5ONE N67W84NE N72W65SW N42W46NE N65W58SW N88E25SE N68W42SW N79E 54 NW N45W45SW N73E13NW N1OE32NW
N59W40SW N56W83NE N55W68NE N35E26NW N48W $45 \mathrm{NE}$ N9OE $46 \mathrm{~S}$ N90W39N N80W85NE N78W77 SW N7 OW22SW N55W60SW N50W43NE N45E 45SE N56W76NE N60E48SE N86W75NE N7 3W45SW N45W63SW N23W52SW N85W63NE N7 3E50NW N18E12SE N84W54NE

\section{CLEAVAGE ATTITUDES}

N77W7ONE N38W9ONE N59W8 $5 \mathrm{NE}$ N57W9ONE N43W9ONE N60W90NE N65W75 SW N67W85SW N59W80SW N55W9ONE N80W8 $5 \mathrm{NE}$ N88W90NE N43W9ONE N6 3W7 DSW N46W9ONE N69W90NE

N5 1 W9ONE
N30W63NE
N25W85SW
N85W9ONE
N45W75SW
N78W87SW
N59W80SW
N64W85SW
N74W65SW
N85E70SE
N69W9ONE
N85E90SE
N56W75NE
N89E7 S SE
N59W70SW
N82E90NW

N90E35S N8OW8OSW N32W7ONE N66W90NE N4 1W9ONE N79W8ONE N7 OW9ONE N62W75SW N80W80SW N15W80SW N39W10SW N40W90SW N4OW7DSW N87W65NE N44W9 ONE N41W70SW
N6.3W90NE N55W9ONE N62W90NE N72W85SW N7 3W9ONE N47W9ONE N62W80SW N5 3W75SW N75W90NE N54W65NE N5 4W65SW N78W9ONE N8OW6 ONE N77W70SW N69W80SW 
N7 3W80NE N60W80SW N72W8ONE N90W75S N60W7 DNE N67W78NE N60W84NE N58W88NE

N85E52NW N35W75SW $\mathrm{N} 25 \mathrm{~W} 15 \mathrm{NE}$ N35W6 $4 \mathrm{NE}$ N65W23SW N80W35SW N38W 48NE N3OW8 ONE N82E80NW N65E38SE N60W4DNE N7 OE $305 E$ N75WBONE N60E28SE N10W90SW N4OW7 ONE N75W55SW N67W40SW N55W65SW N78E26SE N60W57NE N90E36S N84E3DSE N82W60SW N88W32SW N7 4E42SE N80W40SW N7 OW 34SW N36W48SW N70E38SE N42W6ONE N62W40SW N60W9DSW N62W42SW N04W46NE N02W56 NE N40E 46SE N7 OW34SW N80E36SE N64W48SW N5OW 44NE
N70W635W N45W78SW N53W88SW N59W89NE N90E75S N85W85NE N55W83SW N35W79SW
N86W60NE N81W75SW N80W85NE N70W85SW N7 OW87NE N45W82NE N77W83NE N82W56NE
N40W865W N27W79SW N45W88NE N44W87NE N57W70SW N62W80SW N37W81NE
N70W80SW N82E72SE N7 4W70NE N60W80NE N3 5 W5 $7 \mathrm{NE}$ N55W75 SW N57W84NE
N5.3W76SW N51W80SW N53W87NE N67W90SW N55W85NE N67W68SW N49W85NE

\section{APPENDIX 3. SUNSHINE SUBAREA BEDDING DATA}

N8OE 44NW NOOE $15 E$

N1 - W6ONE N15W54NE N5DW5ONE N48W4ONE N45W4OSW N2OW55NE N7 OE 40SW N8OE2OSE N75W 15 SW N5OW3ONE N75W30SW N8OW 48 SW N7 OW65NE N6DE20SE N3OW3ONE N80W76SW N78W64SW N28W75NE N9DE30S N50W10SW N56E40SE N86W $38 \mathrm{NE}$ N8OE 4OSE N18E3DSE N28W67NE N38W46SW N78E14SE N8DE $345 E$ N66W40SW N45W30SW 44W76NE N58E30SE N12W5 4NE N7 4E 44SE N6DE4OSE N7OW7ONE N48W66 SW ND6W68NE N52E36SE
N60W40SW N1OW3ONE N65W40SW N5 4W5DNE N45E65SE N60E24SE N2OW46NE N60E $185 E$ N45W55NE N80E56SE N1 OWO $8 \mathrm{NE}$ N7 OW 34 SW N76E22NW N36W36SW N55W42SW N80E30NW N45W7 0SW N7 OE2BSE N3OW3ONE N9DE26S N10W60SW N58W42SW N11E34SE N76E58SE N18E12SE N18W70NE N24W44SW N14E 44SE N84W28SW N42W5OSW N64W18SW N46E9DSE N4OE $30 S E$ N08W56NE N7DE66SE N60E54SE N7OW74 NE N30W84.SW N6DW48NE N.3DE78SE N5OW4BSW
N1DE40SE NO 4 W28SW N15W5 4NE N10E $55 \mathrm{NW}$ N80W58NE N40W25SW N68W40SW N28E55SE N78E80NW N75E20NW N9DE24S N72E28NW N1 OW45NE N50W60SW N68W64SW N6 4W5DSW N7 4E 48SE N85W30NE N45W55NE N35E2DSE N54W28SW N28E42SE N45W54 SW N20W16NE N16W74NE N3 4 W56 NE N12W42SW N62W32SW N34W58SW N66W45SW N34W60SW N14W70NE N68W45SW N66E48SE N6DW3OSW NO 4 E2 4 NW N30W9DSW N14W44NE N66E34SE N30W 34 SW N66W44SW
N34W185W N50W40SW N20W30SW N30W26NE N30W26SW $\mathrm{N} 45 \mathrm{~W} 55 \mathrm{NE}$ N05W38NE N3DE56SE N1DW6ONE N7 OE 4DSW N42W44NE N36E4DSE N40W60SW N80W67SW N58W48NE N08W16SW NBOW $40 \mathrm{NE}$ N6OW4ONE N45W $35 \mathrm{NE}$ N6 OW30SW N34W445W N75W36 SW N90E2DS NODE66E N90W6OS N10W8 4NE N62E4DSE N78W30SW N80W38SW NOOE 4 OW NOBW70SW N36W3 ONE N9OE4OS N64W34SW N80W42NE N42W. 90 SW N2 4W5ONE N16W90SW N26E7DSE N78W40SW N8 4E 4 4SE

N15E22SE N7OW3DSW N3OW $10 \mathrm{NE}$ N36W44NE N80E5 5SE N80E28SE N80E5 4SE N18W62NE N60E7 4NW N65W25SW N20W56NE N30W60SW N65W6DSW N75E32SE N90W90S N7 OW 38NE N6 OW50NE N85E30SE N80W28SW N38W36SW N6OW5ONE N50W64SW N86W05NE N50E48SE N0 4W56NE 


\begin{tabular}{|c|c|c|c|c|c|}
\hline W5 4NE & N50W48SW & N72E46SE & N66E40SE & N2OW42NE & N56W64NE \\
\hline N40W44SW & N90E16S & N68E32SE & N6 0 W $24 \mathrm{NE}$ & N10E26SE & N40W60SW \\
\hline N90E24S & N78W44SW & N10E65SE & N84W40SW & N70W14SW & N84W48SW \\
\hline N6OW40SW & N72W28SW & N50E36SE & N80E50NW & N66E20SE & N50W66 SW \\
\hline N68E40SE & N8OW76NE & N9OE $40 S$ & N86E20SE & N7 4 W7 6 SW & N60E26SE \\
\hline N80W90SW & N60W78NE & $6 \mathrm{~S}$ & OE20S & OW5ONE & $4 S W$ \\
\hline W22SW & N16E34SE & N64W36SW & N80W30SW & E5 4SE & $S W$ \\
\hline $128 \mathrm{SW}$ & N10W46NE & $4 \mathrm{SW}$ & DW26SW & $270 \mathrm{NW}$ & s \\
\hline $30 \mathrm{NW}$ & N40E38SE & N90E2OS & N50W20SW & N60E40SE & E06E \\
\hline W30SW & N66E36NW & N6OE20SE & N9OE2OS & N80E10NW & $36 \mathrm{SE}$ \\
\hline E2OS & N76W60NE & N7 4W54SW & N70E36SE & N62W26SW & $15 \mathrm{NE}$ \\
\hline N80W26NE & N4OW42NE & N8OE5ONW & N8OE 16SE & N60W52SW & N7 OE $44 \mathrm{NW}$ \\
\hline N7 OW18SW & N40W45SW & N7 OE 42SE & N9OE24S & N60W16SW & E50N \\
\hline N9OE40S & N30W56SW & & N6OEDGSE & W6 $65 W$ & $842 \mathrm{~N}$ \\
\hline OSE & $154 \mathrm{SW}$ & N7 & N64W64SW & N60W & $44 \mathrm{NW}$ \\
\hline & N50 & & N70W & N4OW & $46 \mathrm{NE}$ \\
\hline & $4 S W$ & & SNW & N44W & N90E38N \\
\hline N8OE3OSE & N56W34SW & $66 \mathrm{NE}$ & $8 \mathrm{SW}$ & N80W & OSE \\
\hline N6OE7OSE & N90E34S & $64 \mathrm{SW}$ & N70W36SW & N90E32S & N40E5 \\
\hline
\end{tabular}


APPENDIX 4. 217 SUNSHINE VEIN ATTITUDES EROM 57 VEINS.

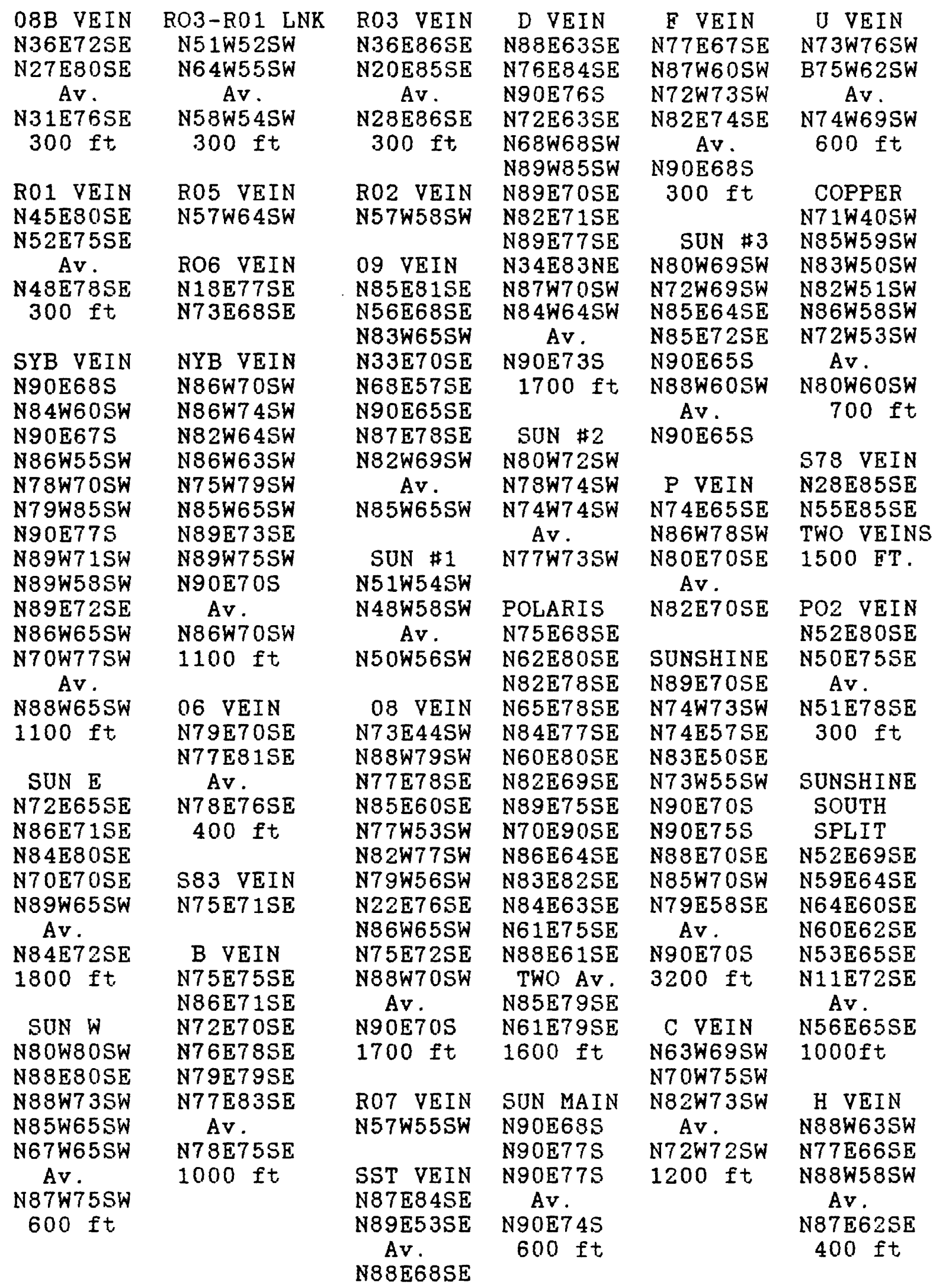




\begin{tabular}{|c|c|c|c|c|c|}
\hline $\begin{array}{l}\text { HOOK } \\
\text { VETN }\end{array}$ & $\begin{array}{l}\text { CHESTER } \\
\text { E VETN }\end{array}$ & CHESTER & YG WEST & $\begin{array}{c}\text { R VEIN } \\
\text { N8OEGOSE }\end{array}$ & $\begin{array}{l}\text { M VEIN } \\
\text { N78E55SE }\end{array}$ \\
\hline N57E75SE & N77E53SE & N78W65SW & N87W745W & N70E55SE & N89E6OSE \\
\hline N82E $66 \mathrm{SE}$ & N81W65SW & N90E74S & N82W68SW & N82W55SW & N89E63SE \\
\hline No6W75SW & N85W59SW & N75E55SE & N33E6 $64 \mathrm{SE}$ & $\mathrm{Av}$ & N82W64SW \\
\hline N7 6E6OSE & N10W65SW & N87W64SW & N84W64SW & N83E57SE & $\mathrm{Av}$ \\
\hline N80E75SE & N89E43SE & N87E54SE & N74E55SE & & N84E68SE \\
\hline N22E87NW & N76W59SW & N89W62SW & N78W62SW & CHESTER & $200 \mathrm{ft}$ \\
\hline NO7E9OSE & N88W65SW & N77E7 OSE & N89E55SE & $N$ VEIN & \\
\hline BETA $=$ & N89W60SW & N40E75SE & $\mathrm{Av}$ & N76E68SE & CHESTER \\
\hline $66 \mathrm{~S} 24 \mathrm{~W}$ & N82W65SW & $A v$ & N83W65SW & N88W68SW & W VEIN \\
\hline $1500 \mathrm{ft}$ & N78W74SW & N88W63SW & $1000 \mathrm{ft}$ & Av. & N83E63SE \\
\hline & N85W67SW & 3300 & & N82E68SE & N7 8E58SE \\
\hline $\begin{array}{l}\text { R24 VEIN } \\
\text { N84W67SW }\end{array}$ & $\begin{array}{r}A v \\
83 w 6\end{array}$ & $6 ? 5$ & CHESTER & 300 ET. & N71W48SW \\
\hline & $2300 \mathrm{ft}$ & N88W52SW & N89E65SE & & $\mathrm{Av}$. \\
\hline SYND. - & & N86E58SE & N82E63SE & VEIN & N88E54SE \\
\hline LINR & CHESTER & N88E56SE & Av & N76E67SE & $600 \mathrm{ft}$ \\
\hline VEIN & HOOK & $\mathrm{Av}$ & N86E64SE & & \\
\hline N7 OW75SW & VEIN & N88E55SE & $300 \mathrm{ft}$ & A VEIN & \\
\hline N79W69SW & N10W80SW & $400 \mathrm{ft}$ & & N67E7OSE & \\
\hline N81W7 OSW & N8OE7OSE & & $J$ VEIN & N77E80SE & \\
\hline $\begin{array}{l}\text { Av. } \\
\text { N77W71SW } \\
600 f t\end{array}$ & $\begin{array}{l}\text { PLOT AS } \\
\text { TWO } \\
\text { VEINS }\end{array}$ & $\begin{array}{l}\text { R22 VEIN } \\
\text { N84E61SE }\end{array}$ & N8OE55SE & $\begin{array}{l}\text { Av } \\
\text { N72E75SE }\end{array}$ & \\
\hline & & & & & \\
\hline
\end{tabular}

Appendix 4. Explanation. Attitudes in various locations within Sunshine mine veins. At the bottom of each vein set, where applicable, an average attitude is given, followed by the vertical interval through which each vein has been mined.

\section{APPENDIX 5. CLEAVAGE DETAIL}

\section{Sunshine Cleavage Domain 1}

Averaged data may be misleading for the Sunshine cleavage, particularly as strike variation is considerable and seemingly atypical for the axial-plane cleavage suggested for the Big Creek anticline. Because the dips are uniformly steep, possible data clusters may be indicated by strike variation; distinct clusters emerge: (a) N60W to N81W, (b) N82W to N87E, and (c) N86E to N65E. Dips are mostly to the south, but a few northerly dips occur in each cluster. Average cleavage trends in sets (a), (b), and (c) may provide a better analytical base than does the average of all cleavage planes. These cleavages have been generated in bedding of rather constant orientation. Figures 67,68 , and 69 show PI plots for the sets (a), (b), and (c). The indicated planes are composited in Figure 70, together with the average bedding. The "conjugate" patterns are noteworthy. The cleavage patterns are not symmetrical on the bedding in this domain, although they lie closer to it than in other domains discussed below; the

"conjugate" patterns are particularly non-symmetrical on the 


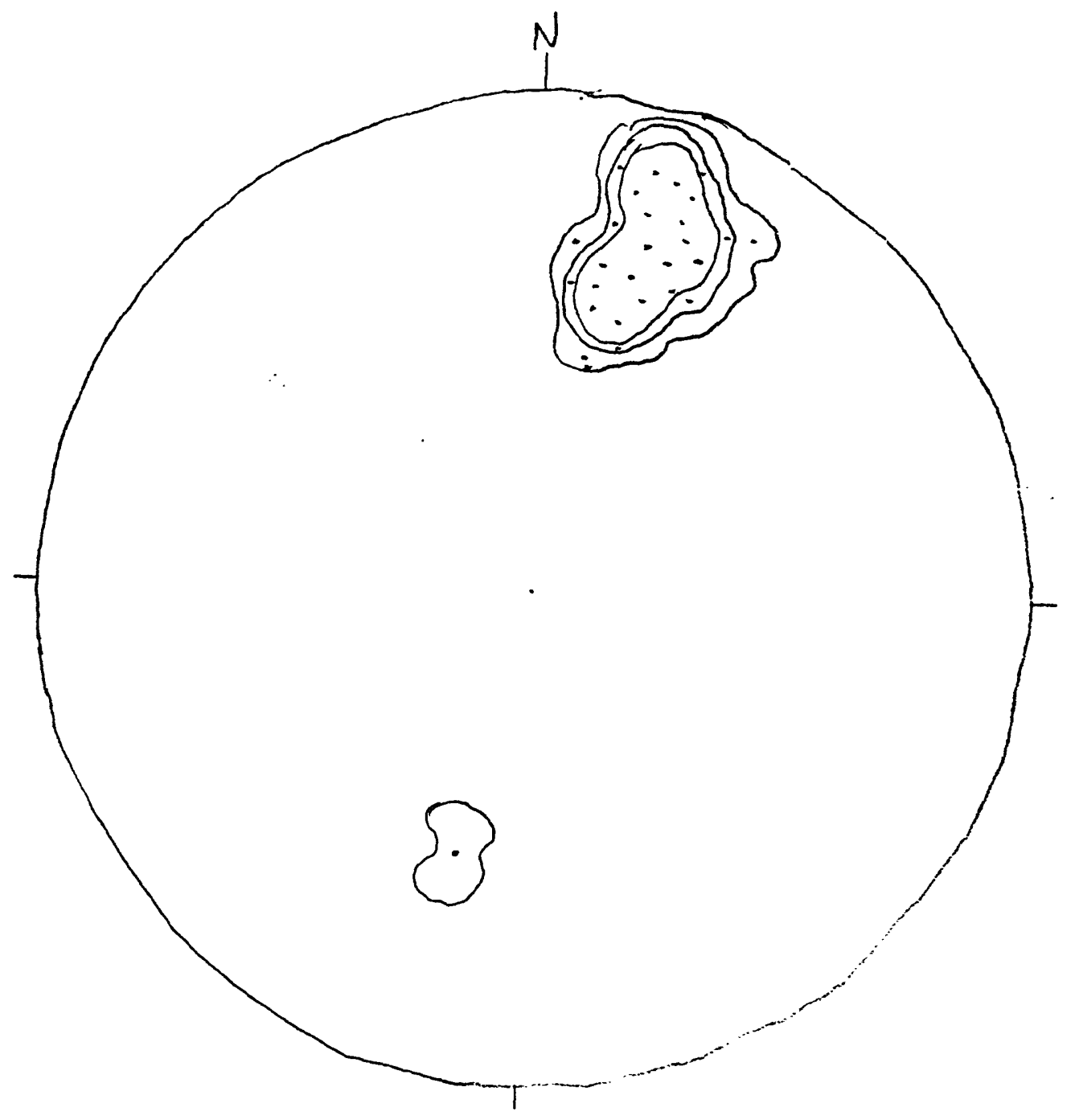

Eigure 67. PI diagram on cleavage set (a), Domain 1, Sunshine mine, Coeur d' Alene district, Idaho. PI maximum $=26 \mathrm{~N} 15 \mathrm{E}$, for average cleavage $N 75 \mathrm{~W} 64 \mathrm{SW}$. A secondary maximum is at $44 \mathrm{~S} 15 \mathrm{~W}$, for average cleavage N75W 46NE (there are only a few of these). $N=33$. contours at $5,10,15 \%$ per $1 \%$ area. Schmidt net, lower hemisphere. 


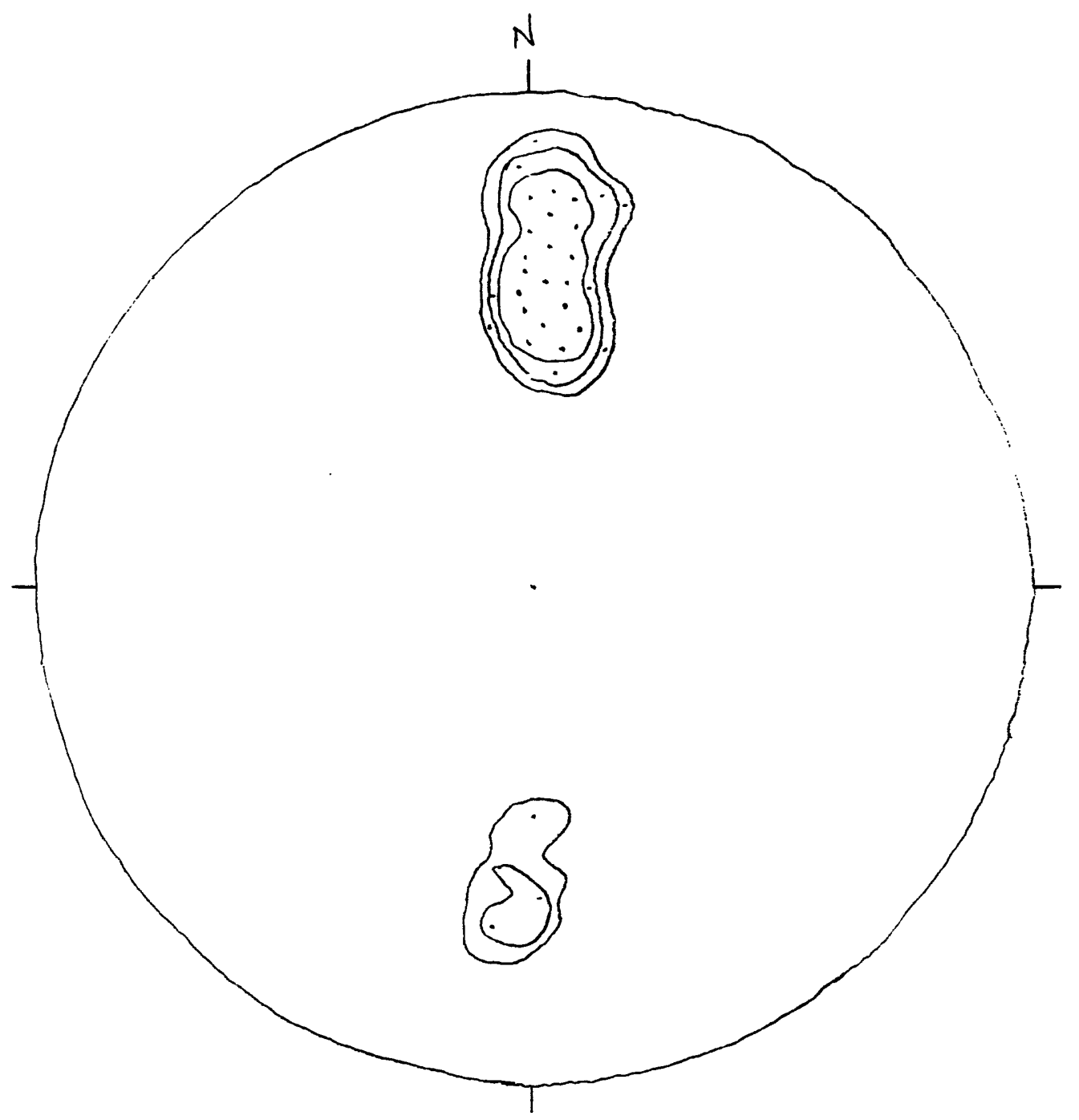

Figure 68. PI diagram on cleavage set (b), Domain 1, Sunshine mine, Coeur $d^{\prime}$ Alene district, Idaho. $N=30$. Maxima at $35 \mathrm{~N} 03 \mathrm{E}$ for average cleavage at $N 87 W 65 \mathrm{SW}$, and at $37 \mathrm{~s} 03 \mathrm{~W}$, for cleavage at N87W $53 \mathrm{NW}$ (a weak set). Contours at $5,10,15 \%$ per $1 \%$ area. Schmidt net, lower hemisphere. 


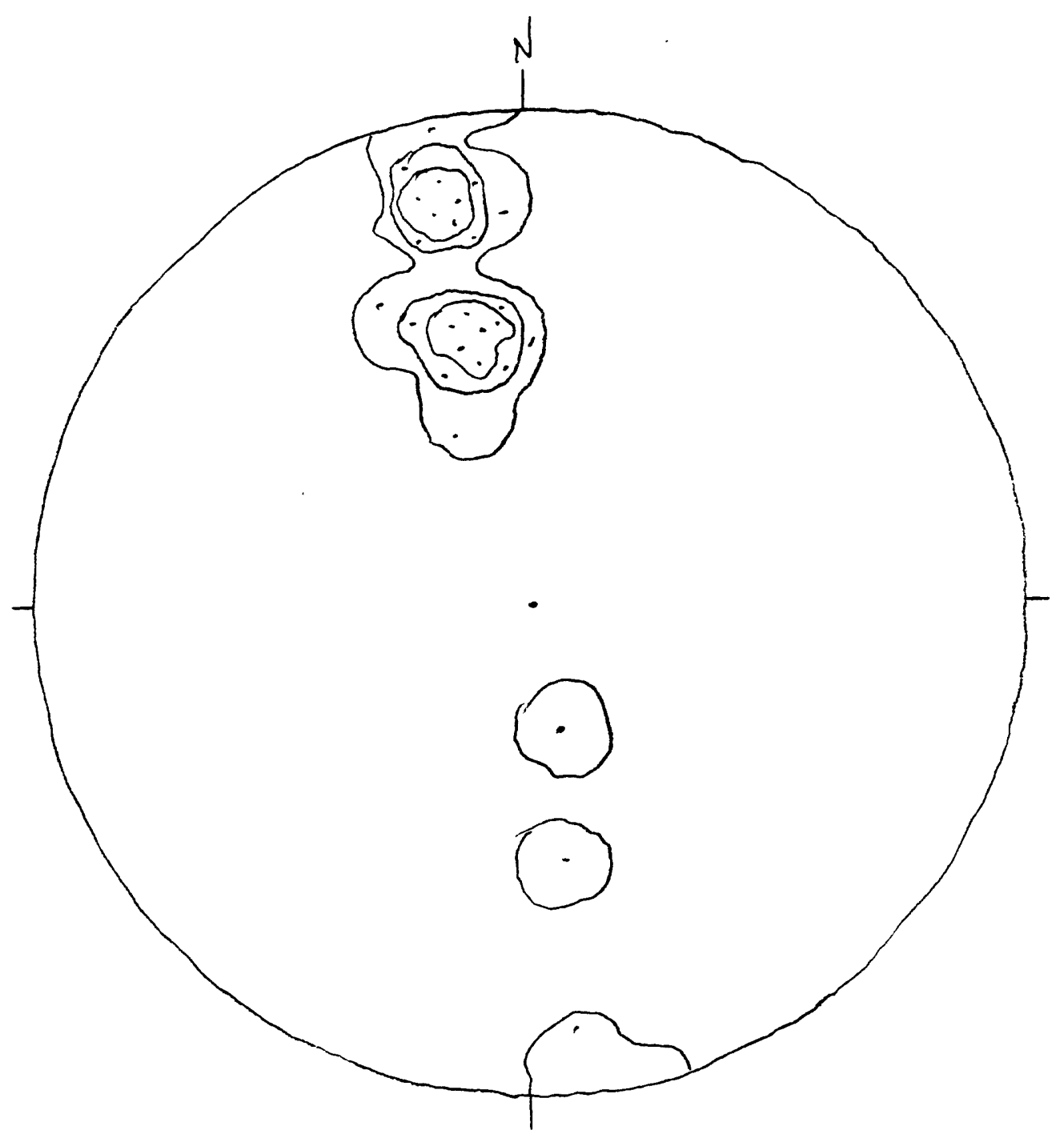

Eigure 69. PI diagram on cleavage set (c), Domain 1, Sunshine mine, Coeur $d^{-}$Alene district, Idaho. $N=16$. Maximum at 32 N10W for average cleavage N8OE 58SE. Contours at $5,10,15 \%$ per $1 \%$ area. Schmidt net, lower hemisphere. 


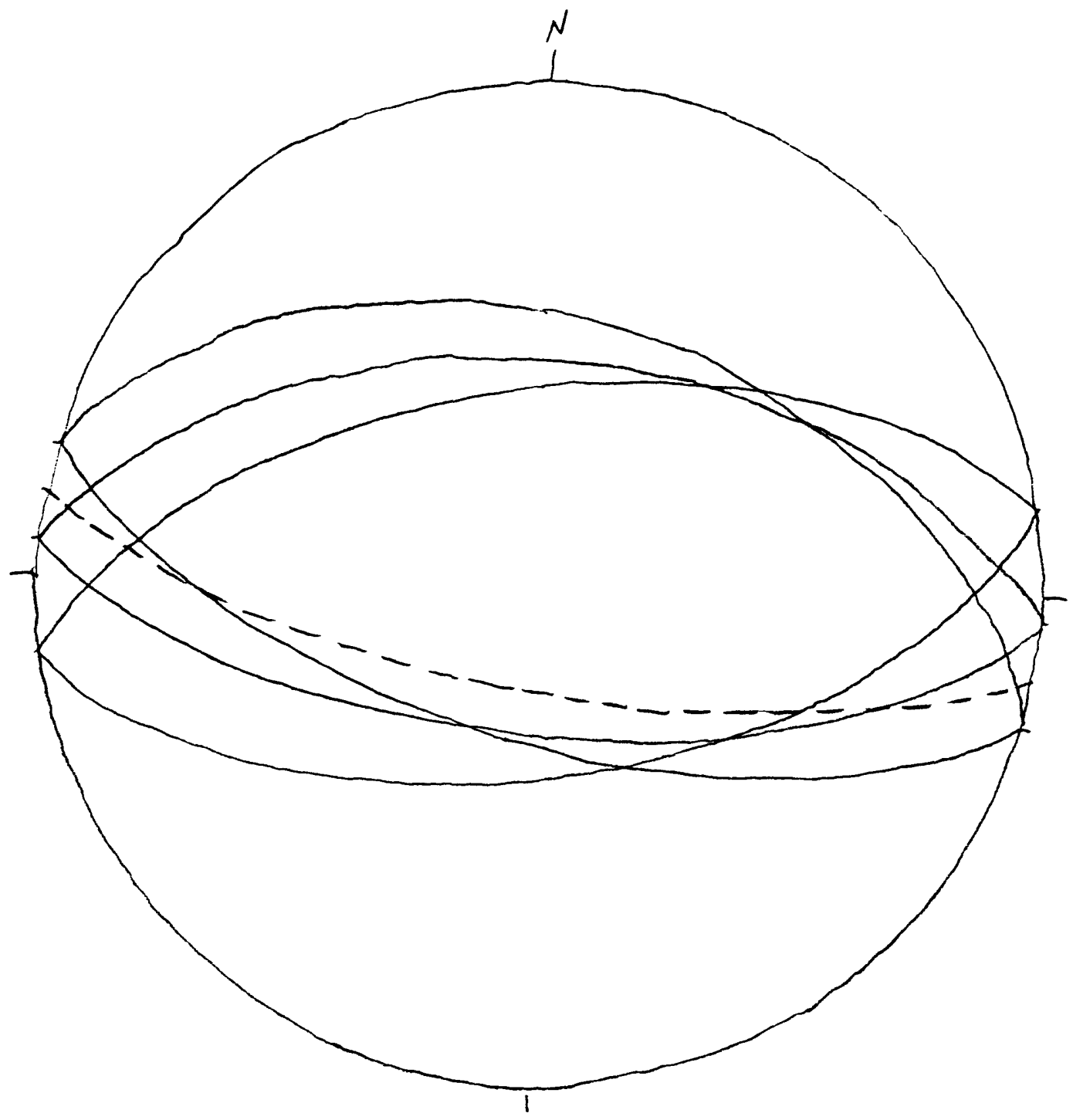

Figure 70. Composite cleavage from sets (a), (b), and (c), Domain 1, Sunshine mine, Coeur $d^{*}$ Alene district, Idaho. Bedding is shown by the dashed line. Schmidt net, lower hemisphere. 
bedding.

\author{
Sunshine Cleavage Domain 2
}

Averaged data may be misleading here as well, particularly as strike variation is considerable and again seemingly atypical for axial-plane cleavage. Because the dips are generally steep, data clusters may be established from strike variation: (a) N54W to $\mathrm{N} 69 \mathrm{~W}$, (b) N7OW to N83W, and (c) N84W to N83E. Note that these differ from those of Domain 1 (Figs. 67, 68, and 69) (see Fige. 71,72 , and 73). The average cleavages from these strike sets are composited in Figure 74 , together with the average bedding from Domain 2. The cleavage is not symmetrical on the bedding, although closer to it again than in other domaine discuesed later.

\title{
Ross Gulch Subarea Detail.
}

Near the the main valley of the South Fork of the Coeur $d^{\text {' }}$ Alene River (Fig. 1), the rocks are in the southwestern flank of the fold structure. The beds are overturned, based on graded bedding. Bedding and cleavage orientations are given in Figure 75. The cleavage-bedding relations are consistent with an overturned $1 \mathrm{imb}$, and that $1 \mathrm{imb}$ may be in fault contact, under a covered zone, with rocks farther north, of northeasterly dip. Farther north, beds still dip southwest, but the cleavage shows a marked change in orientation (Fig. 76). It is tempting to think of folded cleavage (Eig. 77), but bedding orientations are inconsistent with such a mechanism. Moreover, calculated and measured hinges do not match. Finally, at two closely adjacent, points across constant bedding, the bedding-cleavage angle changes from $34^{\circ}$ to $64^{\circ}$. The two cleavages might be of different ages, but there is only one cleavage at each place, and the cleavages are of identical aspect.

Continuing north beyond the covered zone, we pass into the northeast limb of the fold. Beds are uniformly upright on this limb, based on graded and cross bedding. Data for beds, cleavage, and rods are given in Eigure 78. Cleavage again shows a marked change in orientation. Its intersection with bedding is well off the orientation of rodding. Cleavage is nearly perpendicular to bedding in a much larger angle than seen previously. Again, this change in orientation is inconsistent with the more or less constant bedding attitudes. Figure 79 shows four beds in a BETA array on the assumption of an anticline. Its elements are inconsistent with cleavage orientations; its axis is in the regional trend, however, at 68 N43W.

Earther north in this same limb, bedding, cleavage, minor hinges and rods are oriented as shown in Figure 80 . Hinges, rods, and bedding-cleavage intersections show widely varied trends. The bedding-cleavage angle is large.

Still farther north (Fig. 81), the bedding-cleavage angle becomes markedly smaller $\left(18^{\circ}\right)$, with cleavage dipping shallower than bedding; clearly incongruous, as graded bedding is well developed, showing an upright limb. Moreover, two minor folds 


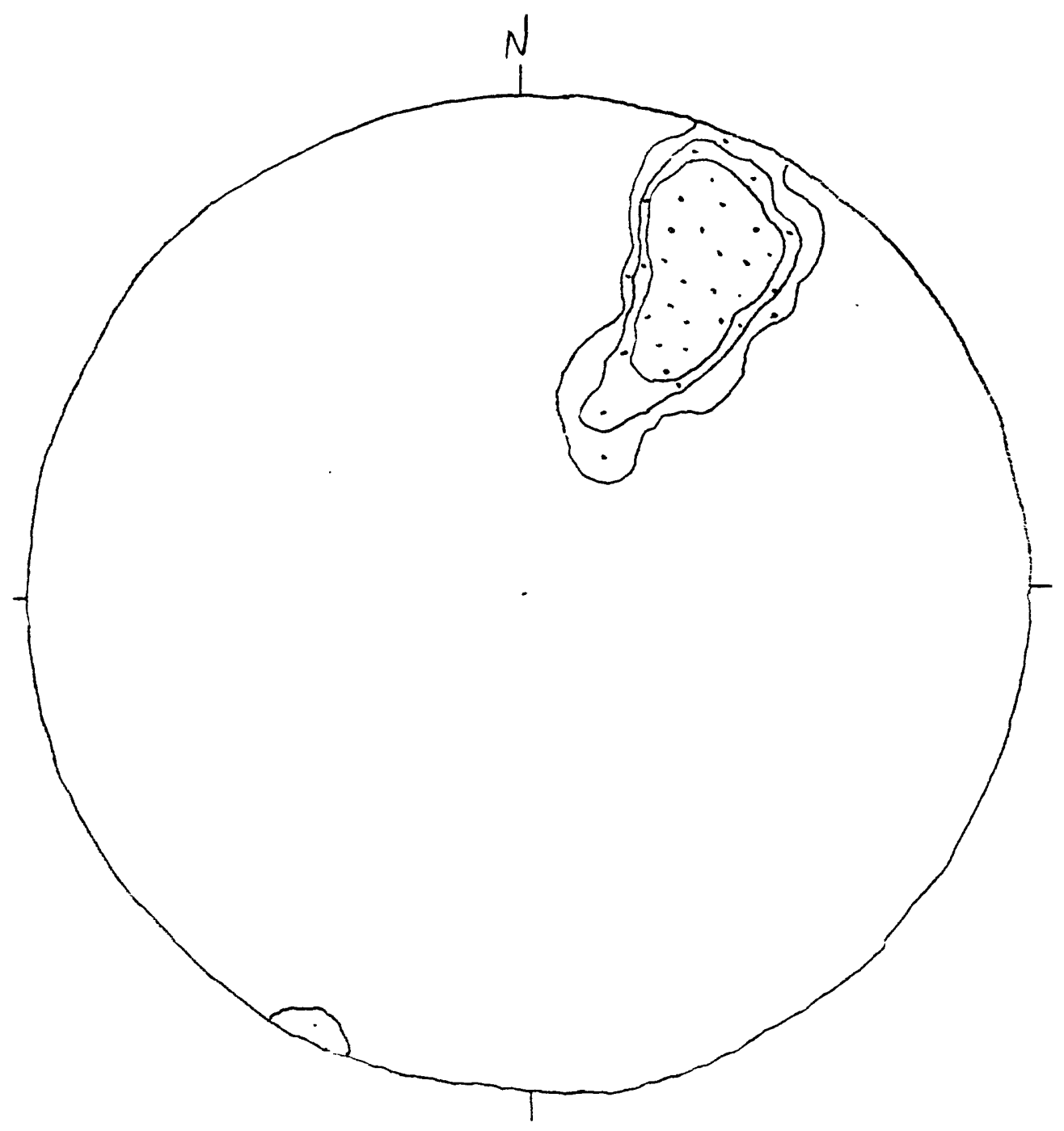

Eigure 71. PI on cleavage set (a) in Domain 2, Sunshine mine, Coeur $d^{-}$Alene district, Idaho. $\mathrm{N}=40$ of 59 planes. $\mathrm{PI}$ maximum $=25 \mathrm{~N} 29 \mathrm{E}$ (average cleavage $=\mathrm{N} 61 \mathrm{~W} 65 \mathrm{SW}$. Contours at $5,10,15 \%$ per $1 \%$ area. Schmidt net, lower hemisphere. 


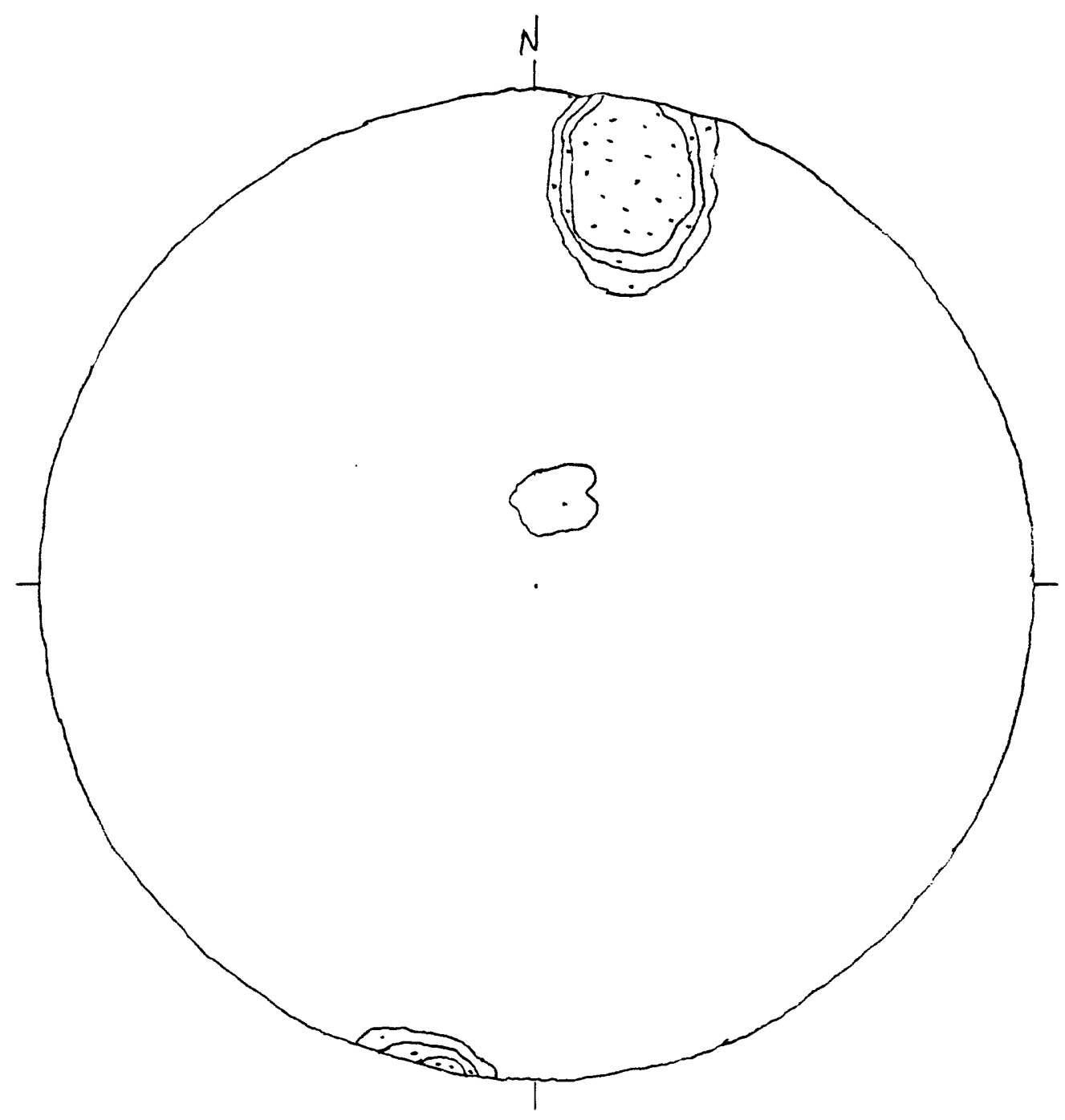

Eigure 72. PI on cleavage set (b), Domain 2, Sunshine mine, Coeur d; Alene district, Idaho. $N=48$ of 94 planes. $P I$ maximum $=16 \mathrm{~N} 13 \mathrm{E}$ (average cleavage $=\mathrm{N} 77 \mathrm{~W} 74 \mathrm{SW}$ ). Contours at $5,10,15 \%$ per $1 \%$ area. Schmidt net, lower hemisphere. 


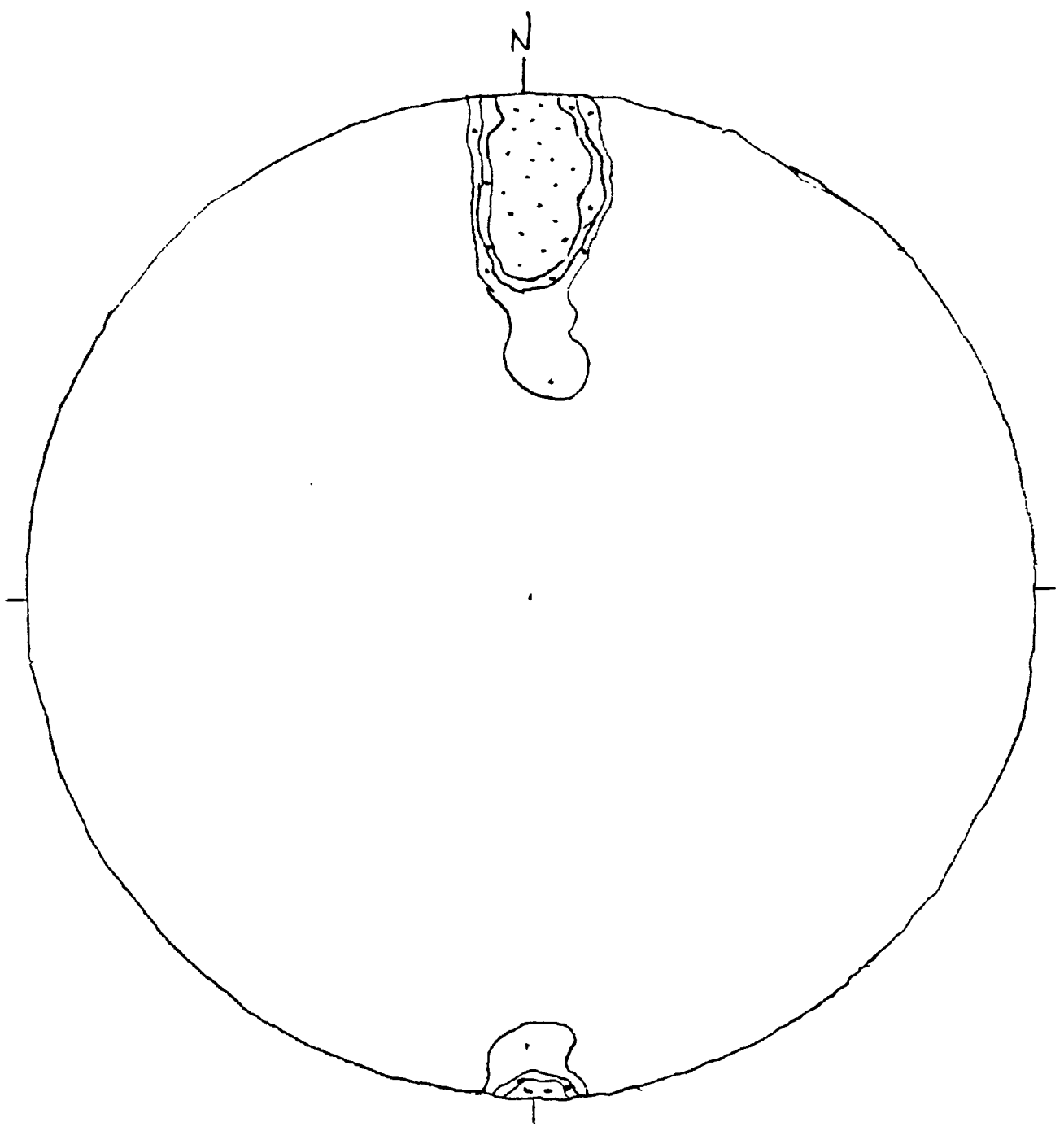

Eigure 73. PI on cleavage set (c), Domain 2, Sunshine mine, Coeur $d^{-}$Alene district, Idaho. $N=42$ of 81 planes. PI maximum $=18$ NOOE (average cleavage N9OE $72 S$ ). Contours at $5,10,15 \%$ per $1 \%$ area. Schmidt net, lower hemisphere. 


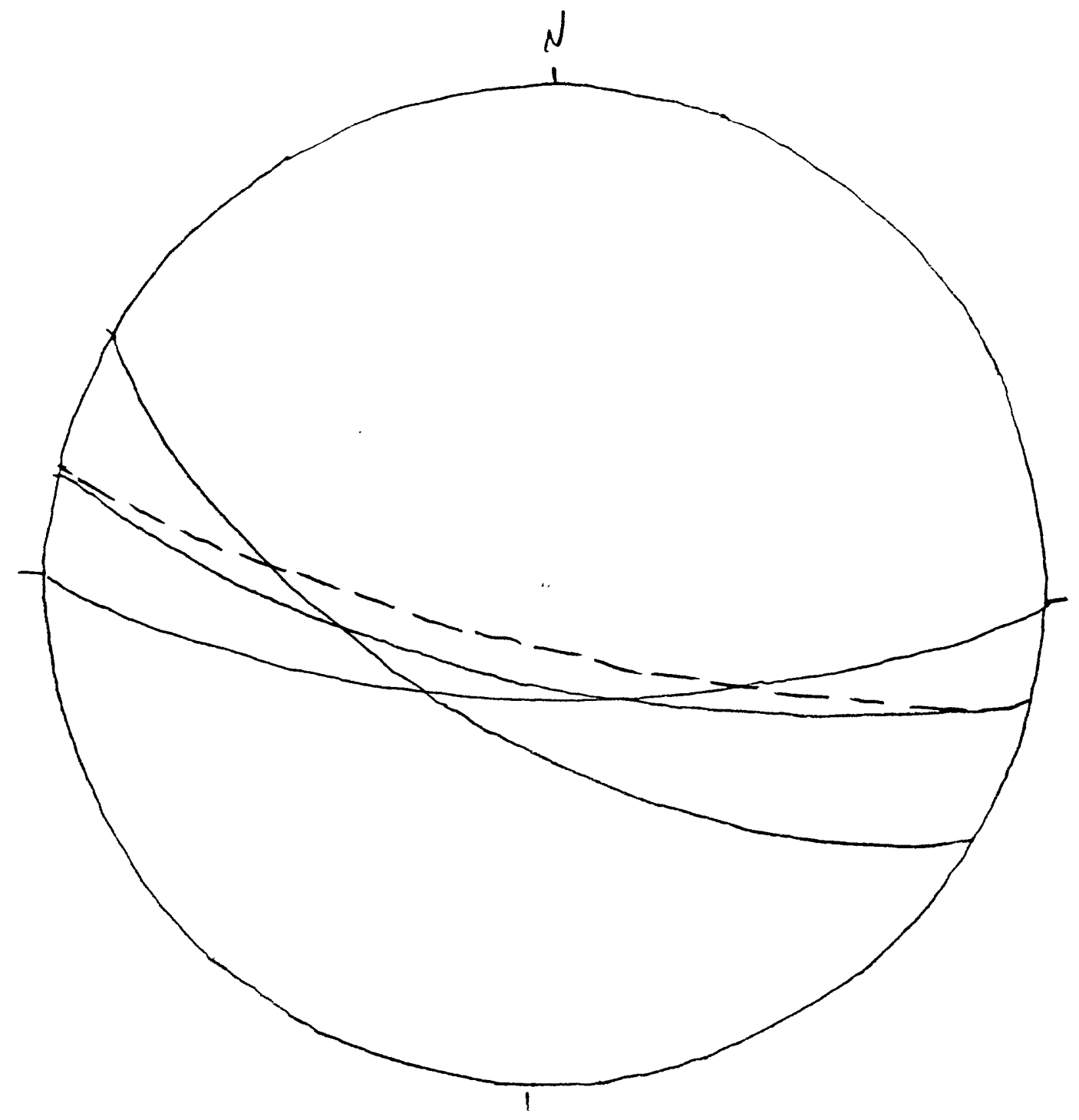

Eigure 74. Three average cleavage planes, Domain 2, Sunshine mine, Coeur d'Alene district, Idaho. Average bedding: N78W $80 \mathrm{SW}$, shown by the dashed line. Schmidt net, lower hemisphere. 


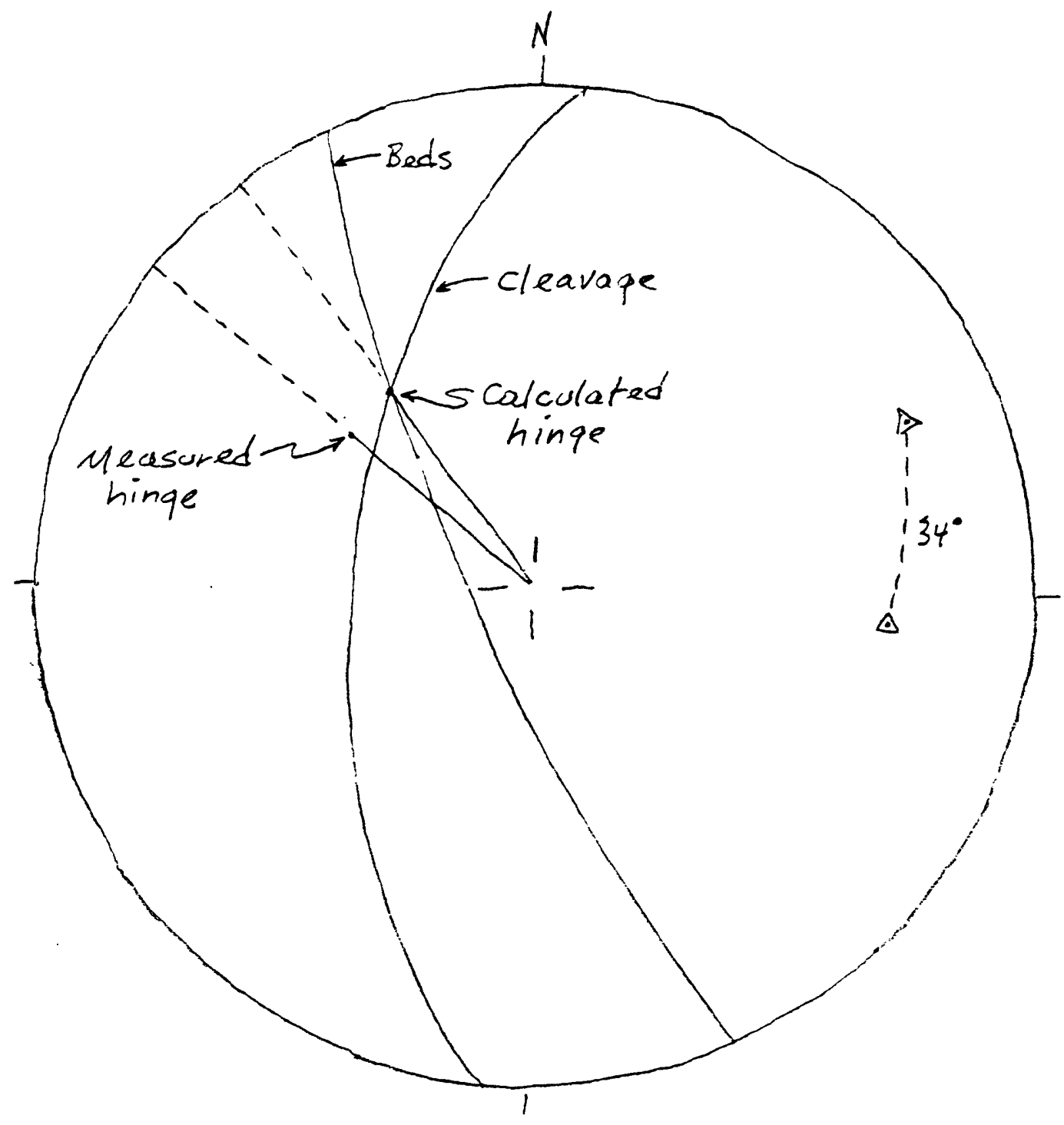

Eigure 75. Bedding-cleavage relations at a point in the Ross Gulch subarea, Coeur d' Alene district, Idaho. Graded bedding faces northeast. Beds N25W 80SW. Cleavage N05E 60NW. Calculated hinge $48 \mathrm{~N} 36 \mathrm{~W}$. Measured hinge 50 N50W. Beddingcleavage angle $34^{\circ}$. Schmidt net, lower hemisphere. 


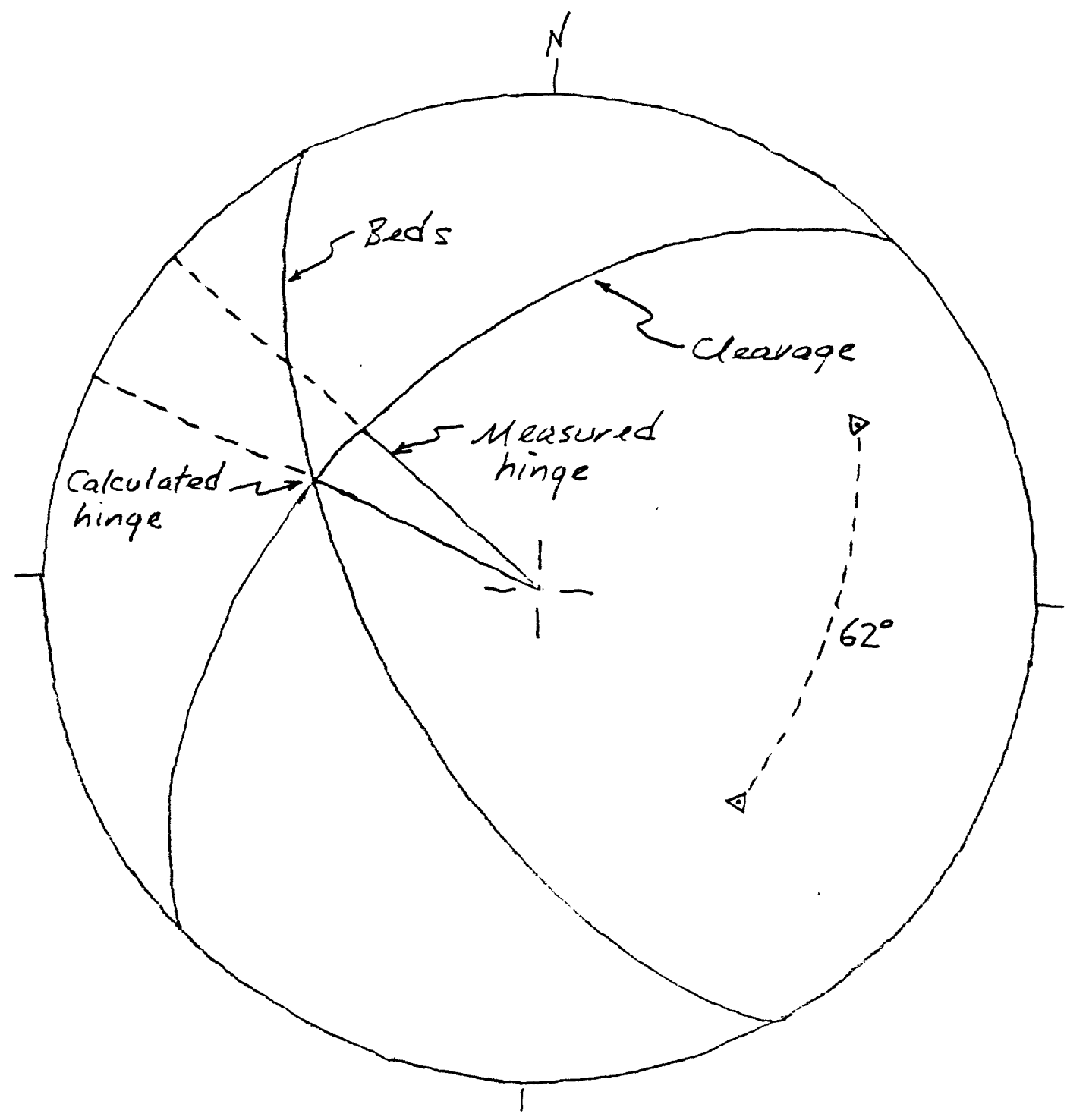

Figure 76. Bedding-cleavage relations at a point in the Ross Gulch subarea, Coeur d' Alene district, Idaho. Bedding N3OW 62SW. Cleavage N45E 50NW. Calculated hinge; 48 N66W. Measured hinge $50 \mathrm{~N} 50 \mathrm{~W}$. Bedding-cleavage angle $62^{\circ}$. Schmidt net, lower hemisphere. 


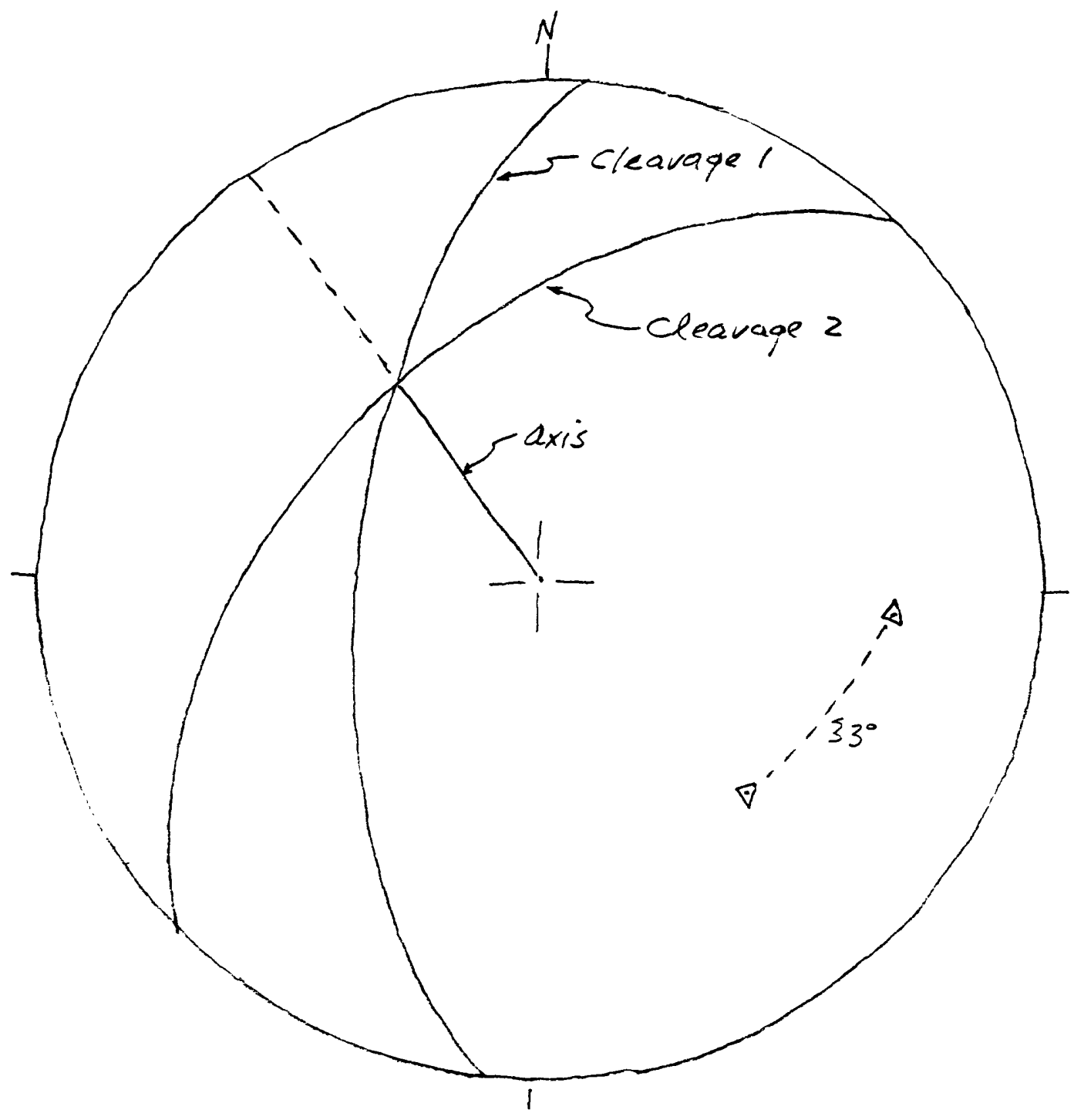

Eigure 77. Cleavages from the two previous figures to portray a possible axis for folded cleavage $(50 \mathrm{~N} 39 \mathrm{~W})$. Schmidt net, lower hemisphere. 


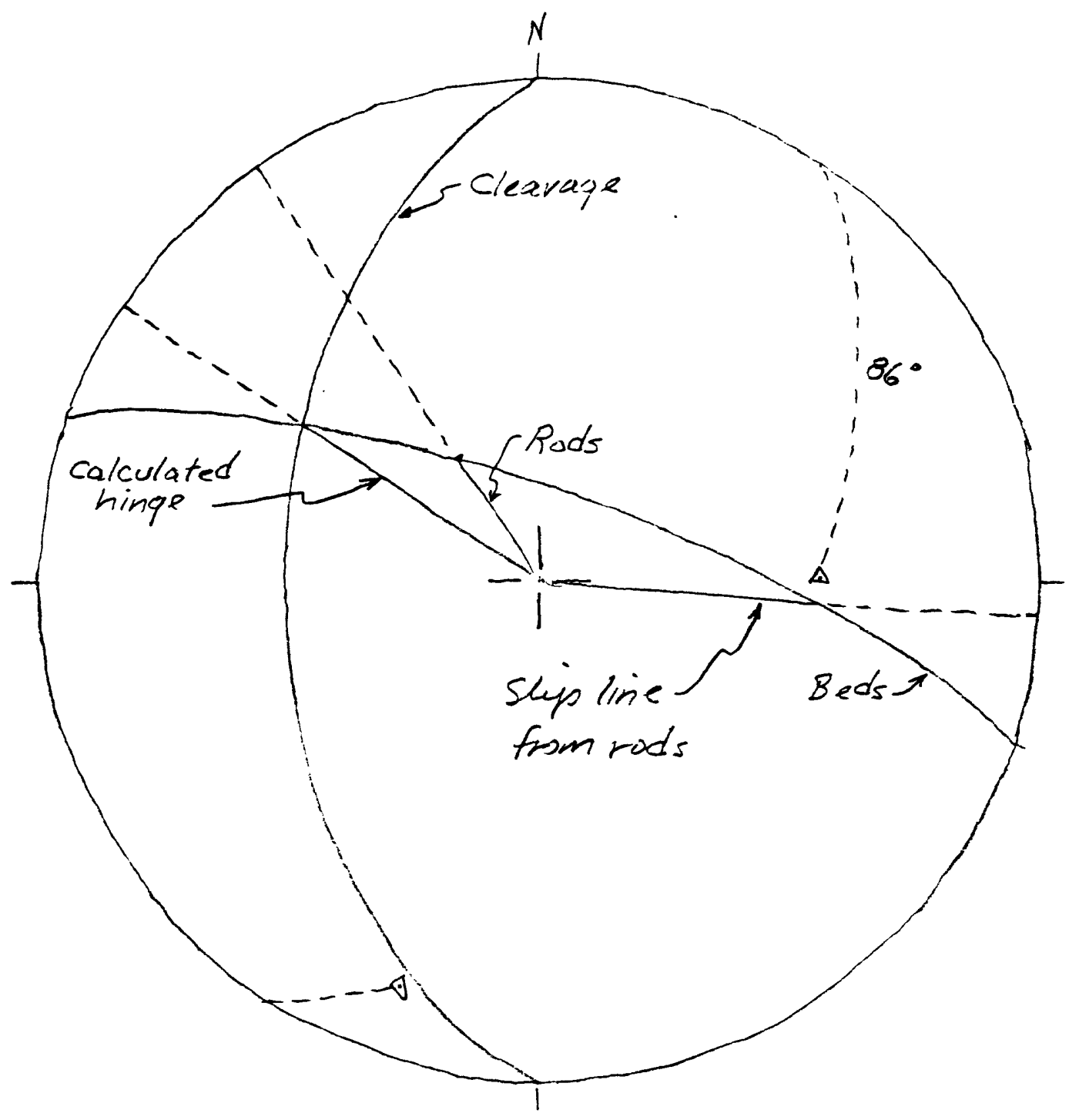

Figure 78. Bedding-cleavage-rodding relations at a point in the Ross Gulch subarea, Coeur d' Alene district, Idaho. Bedding N70W 75NE. Cleavage NoOW $47 \mathrm{~W}$. Calculated hinge 48 N55W. Measured rods $65 \mathrm{~N} 34 \mathrm{~W}$. Bedding-cleavage angle $86^{\circ}$. Slip line perpendicular to rods in the bedding $44 \mathrm{~S} 86 \mathrm{E}$. Schmidt net, lower hemisphere. 


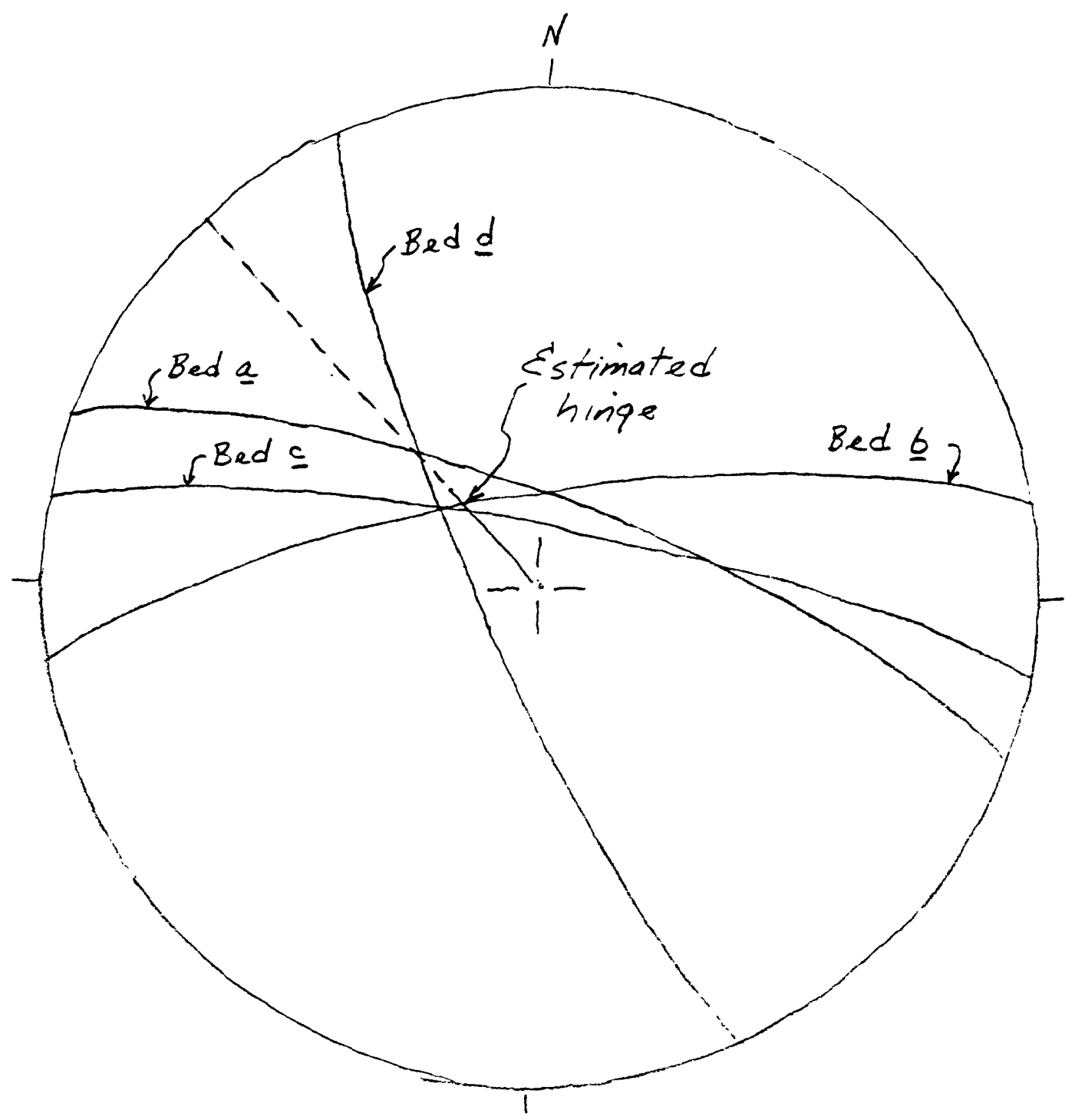

Eigure 79. Four beds from the fold in the Ross Gulch subarea, Coeur d' Alene district, Idaho. Bed a N;70W 75NE. Bed b N8OE $75 \mathrm{NW}$. Bed $c$ N80W 80NE. Bed $d$ N25W $80 \mathrm{SW}$. Beds face north at all four stations. Estimated hinge $68 \mathrm{~N} 43 \mathrm{~W}$. Schmidt net, lower hemisphere. 


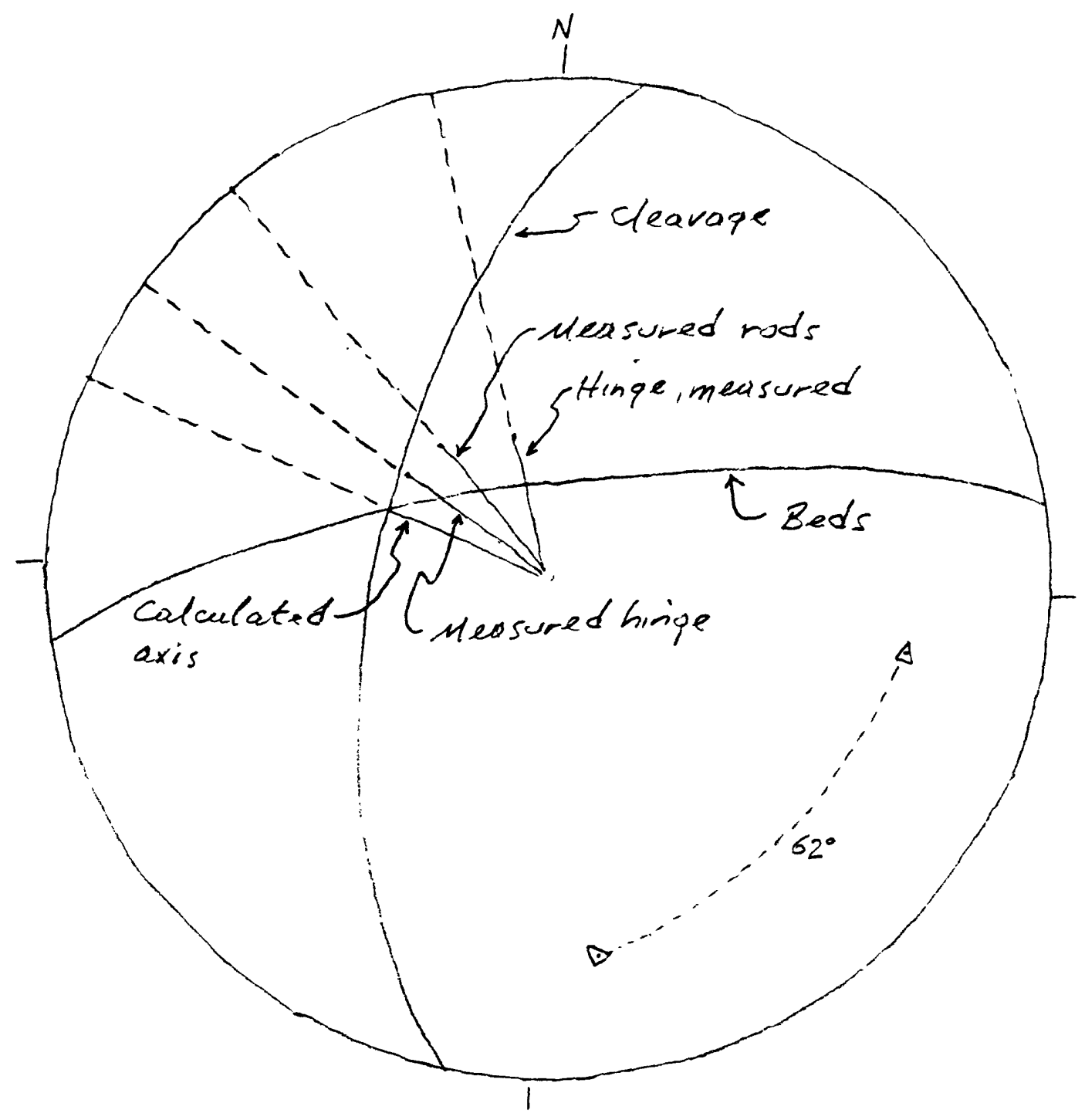

Eigure 80. Bedding-cleavage-hinge-rodding relations at a point in the Ross Gulch subarea, Coeur d' Alene district, Idaho. Beds N80E 75NW. Cleavage N1OE 62NW. Bedding-cleavage intersection 62 N70W. Bedding-cleavage angle $62^{\circ}$. Rods 62 N40W. Measured hinges $62 \mathrm{~N} 55 \mathrm{~W}$ and $66 \mathrm{~N} 15 \mathrm{~W}$. Schmidt net, lower hemisphere. 


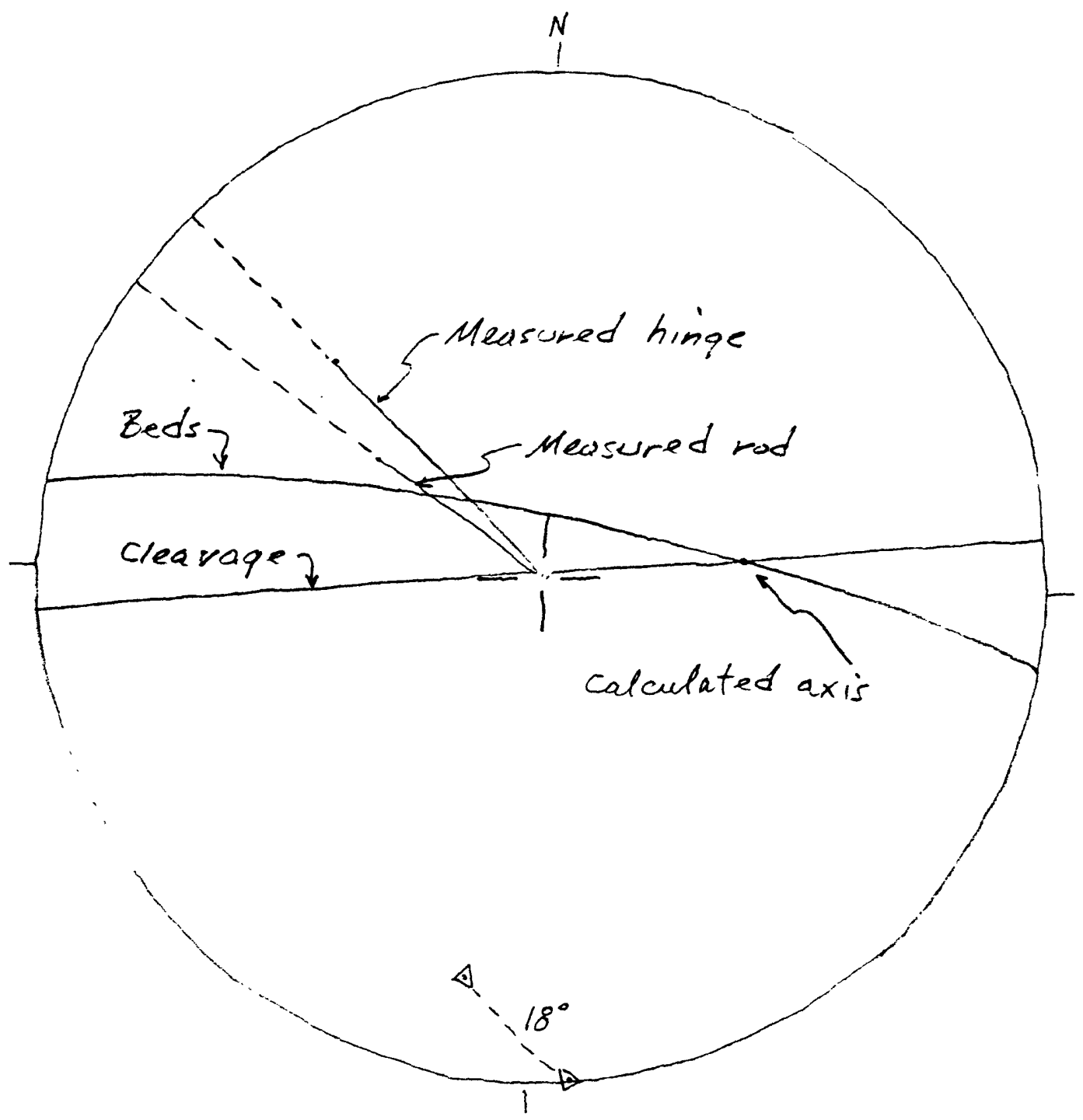

Figure 81. Bedding-cleavage-rodding-hinge relations at a point in the Ross Gulch subarea, Coeur d' Alene district, Idaho. Beds N80W $80 \mathrm{NE}$. Cleavage N85E 90SE. Bedding-cleavage intersection 54 N85E. Bedding-cleavage angle $18^{\circ}$. Measured hinge $40 \mathrm{~N} 45 \mathrm{~W}$. Measured rods $57 \mathrm{N5} 5 \mathrm{~W}$. Schmidt net, lower hemisphere. 
are present, apparently incongruous in the beds. The beddingcleavage intersection is far off the minor hinge and rod orientations, themselves rather different.

Farther on north, bedding and cleavage are parallel, near a quartzite unit. Beyond the quartzite, again in argillite (Eig. 82 ), the bedding-cleavage angle remains small ( $\left.19^{\circ}\right)$, and minor folds appear to be incongruous, suggesting overturn in clearly upright beds. Some of those minor folds wrap bedding-parallel cleavage.

Still farther north, the bedding-cleavage intersection trends due north (Fig. 8.3), and the bedding-cleavage angle remains small $\left(24^{\circ}\right)$.

An early, tight isoclinal fold with its axial plane more or less in the bedding is shown in Eigure 84 . It is early, incongruous, and apparently refolded; regarded as an $F 1$ element.

Composite plots of bedding (Eig. 85) and cleavage (Eig. 86) to show BETA aspects, average to show a common axis oriented near $55 \mathrm{~N} 65 \mathrm{~W}$.

In some more-detailed work on the origin of the metamorphic cleavage, the University of Idaho graduate metamorphism class and the senior author gathered detailed structural data from the Ross Gulch subarea in September, 1990, during a one-day field trip and over a traverse about $0.25 \mathrm{mi}$ long across the general strike. Pooled subarea data provided a set for statistical analysis. A PI diagram on bedding (Eig. 87) shows a partial girdle whose pole lies at $54 \mathrm{~N} 68 \mathrm{~W}$. A second girdle pole lies at $35 \mathrm{~N} 36 \mathrm{~W}$. Average bedding is oriented near N14W 62SW. The interpretation of two girdles may be wrong; a small-circle girdle for conical folds could also fit the data points. A BETA diagram on bedding (Eig. 88) shows a considerable spread of points in a girdle oriented N25W $65 \mathrm{SW}$ (A); this girdle supports the interpretation of a small-circle girdle in Eigure 87. Major point densities yield maxima at $48 \mathrm{~N} 60 \mathrm{~W}$ and $64 \mathrm{~S} 49 \mathrm{~W}$, both fold axis indicators. Three partial cross-girdles in Eigure 88 ( $B, C$, and $D$ ) are oriented N86W 67SW, N7DE 48SE, and N64W 80NE, respectively.

A PI diagram on cleavage is given in Eigure 89 . Two principal maxima ( $30 \mathrm{~S} 41 \mathrm{E}$ and $40 \mathrm{~N} 84 \mathrm{E}$ ) lie in a diffuse partial girdle, implying two major cleavage trends. The girdle pole plunges $50 \mathrm{~N} 88 \mathrm{~W}$, an axis also defined by the intersection of the two major cleavages (NO4W 50SW and N48E 60NW). A BETA diagram on cleavage (Eig. 90) showe a strong girdle oriented N05W 50SW, with a major point concentration at $50 \mathrm{~N} 88 \mathrm{~W}$. Secondary point concentrations lie at $30 \mathrm{~N} 35 \mathrm{~W}$ and $30 \mathrm{~s} 32 \mathrm{~W}$.

Linear elements well developed in the bedding include minor fold hinges, rods, and boudins. At the outcrop, these elements appear to be related (formed all at the same time), inasmuch as they appear parallel to each other where two or more of them are found together at particular outcrops. Detailed measurements, though, commonly show significant departures from parallelism. These linear elements are plotted in Figure 91; which shows a etrong maximum at $46 \mathrm{~N} 56 \mathrm{~W}$, lying near the BETA axis for folded bedding. In further work, it may be useful to study the orientation of minor folds and rodding separately, rather than compositing them. 


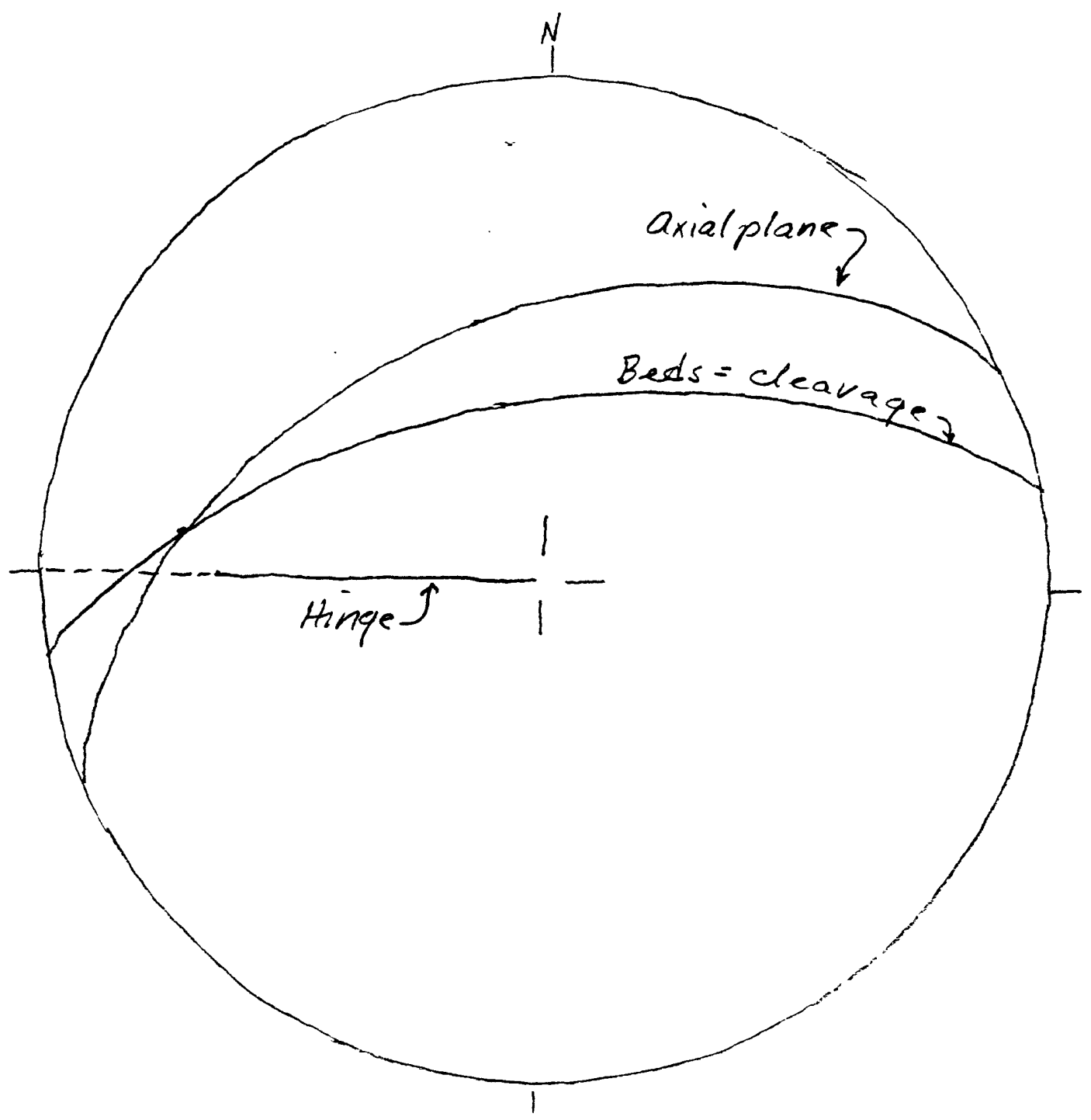

Eigure 82. Bedding-parallel cleavage, incongruously folded (apparently overturned minor fold in upright beds), at a point in the Ross Gulch subarea, Coeur d' Alene district, Idaho. Beds N80E 62NW. Incongruous fold hinge 35 N90W. Axial plane of the incongruous fold N65E $47 \mathrm{NW}$. Schmidt net, lower hemisphere. 


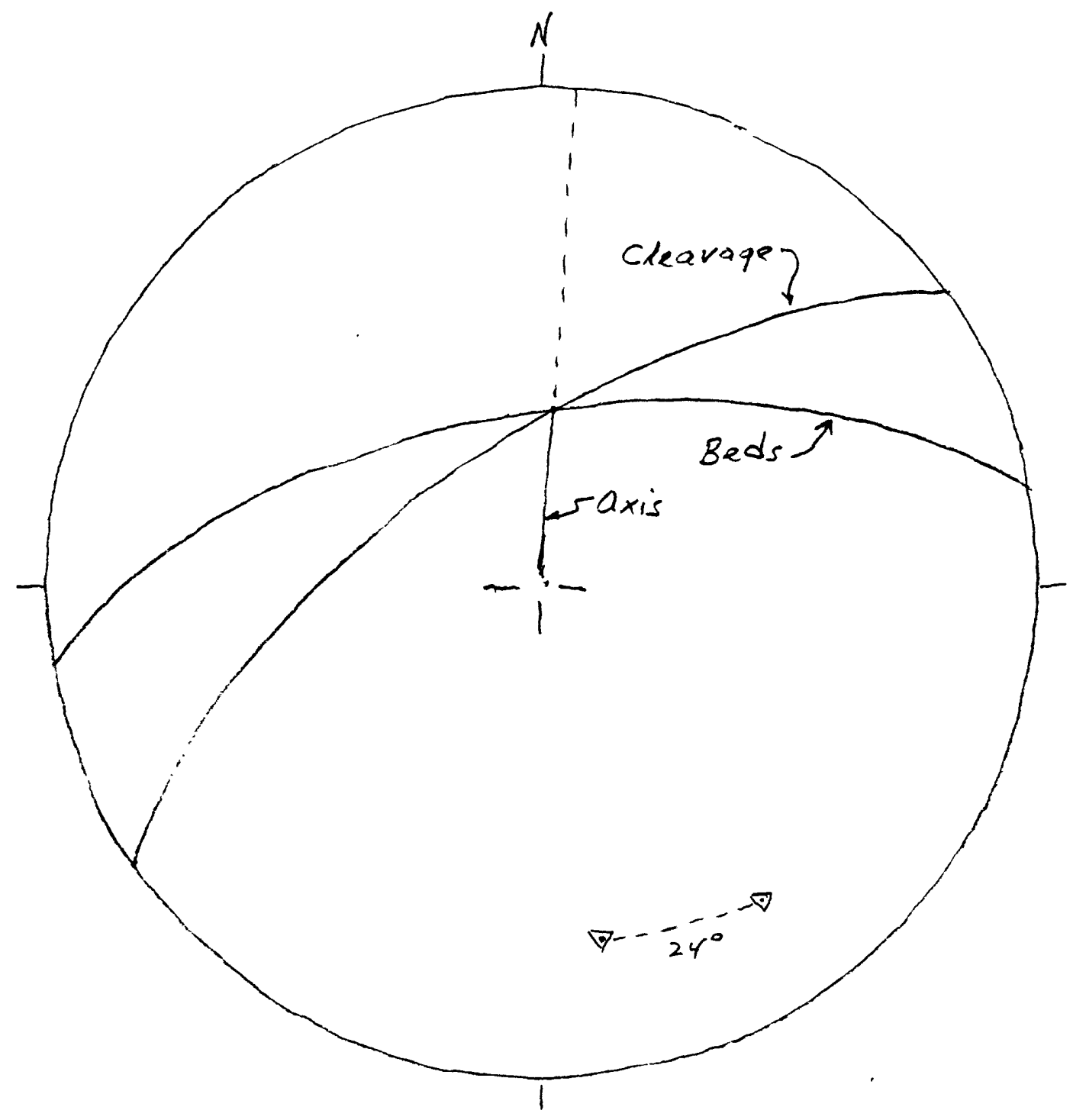

Figure 83. Calculated hinge from the bedding-cleavage intersection at a point in the Ross Gulch subarea, Coeur d' Alene district, Idaho. Beds N80E 62NW. Cleavage N55E 66NW. Beddingcleavage angle $24^{\circ}$. Schmidt net, lower hemisphere. 


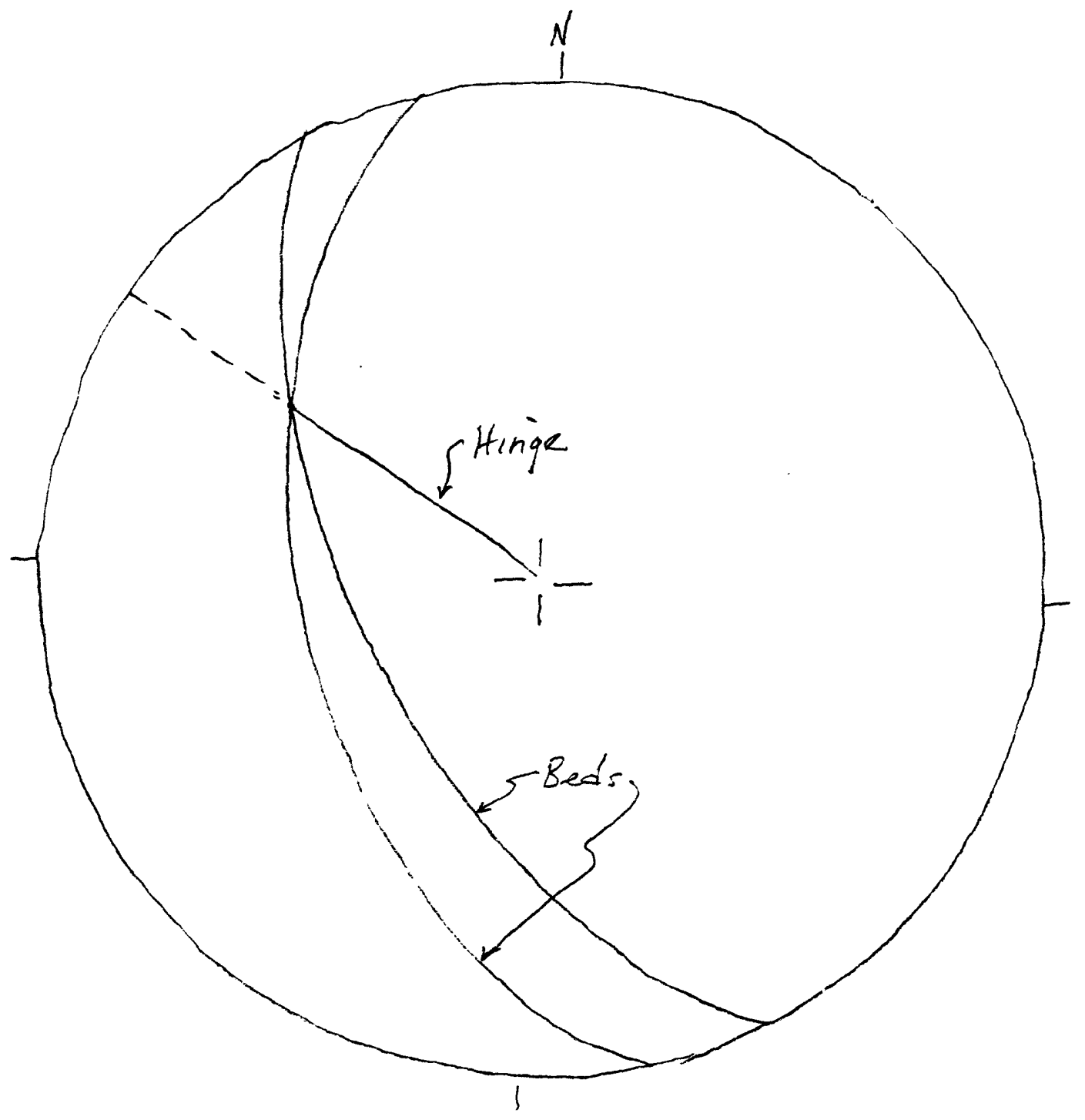

Eigure 84. Early, sub-isoclinal fold, Ross Gulch subarea, Coeur d' Alene district, Idaho. Limbs N15W $505 \mathrm{~W}$ and N30W $60 \mathrm{SW}$. $40 \mathrm{~N} 58 \mathrm{~W}$. Schmidt net, lower hemisphere. 


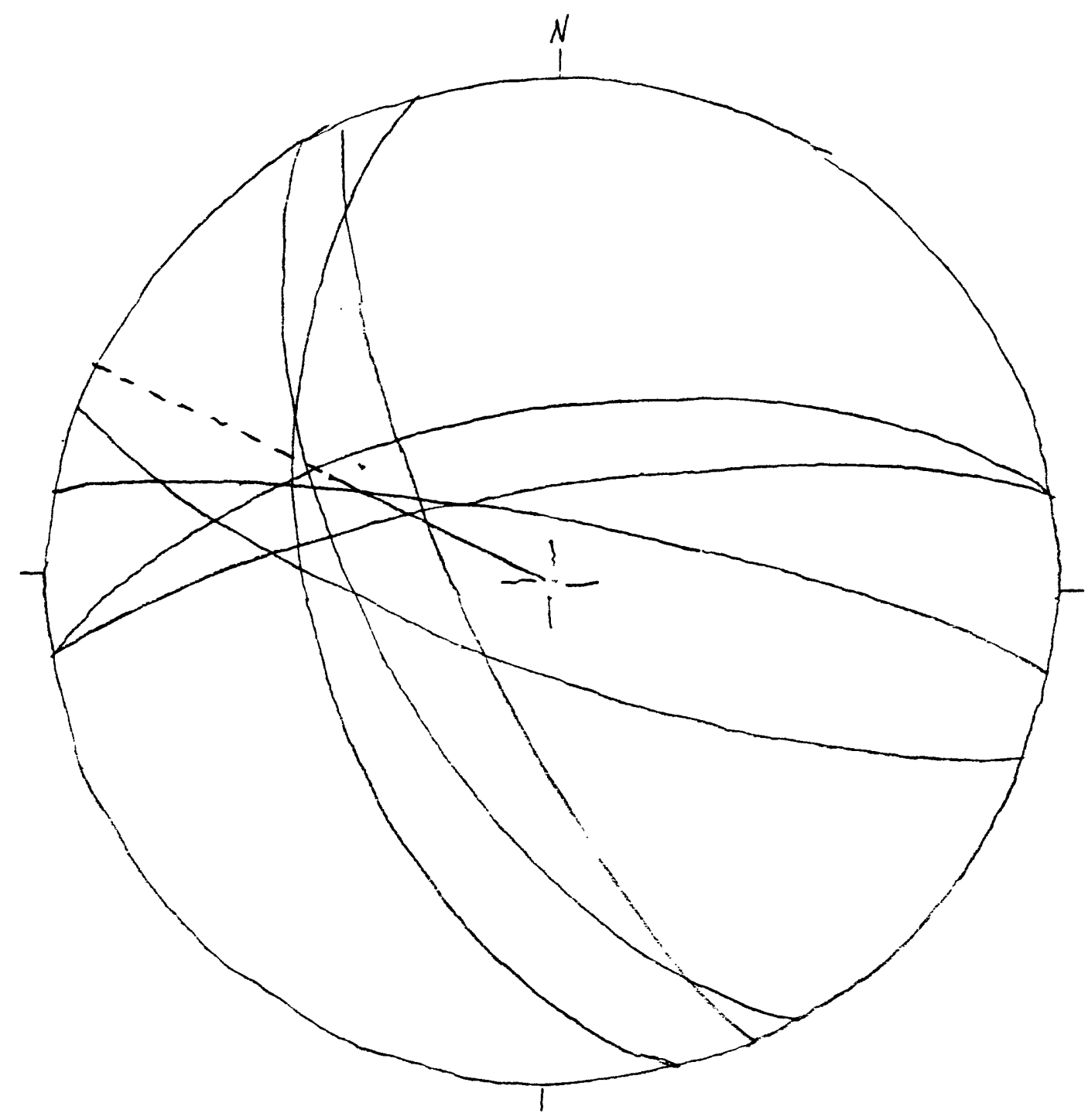

Figure 85. Seven bedding planes from previous figures, Ross Gulch subarea, Coeur d' Alene district, Idaho. Estimated hinge 50 N65W. Schmidt net, lower hemisphere. 


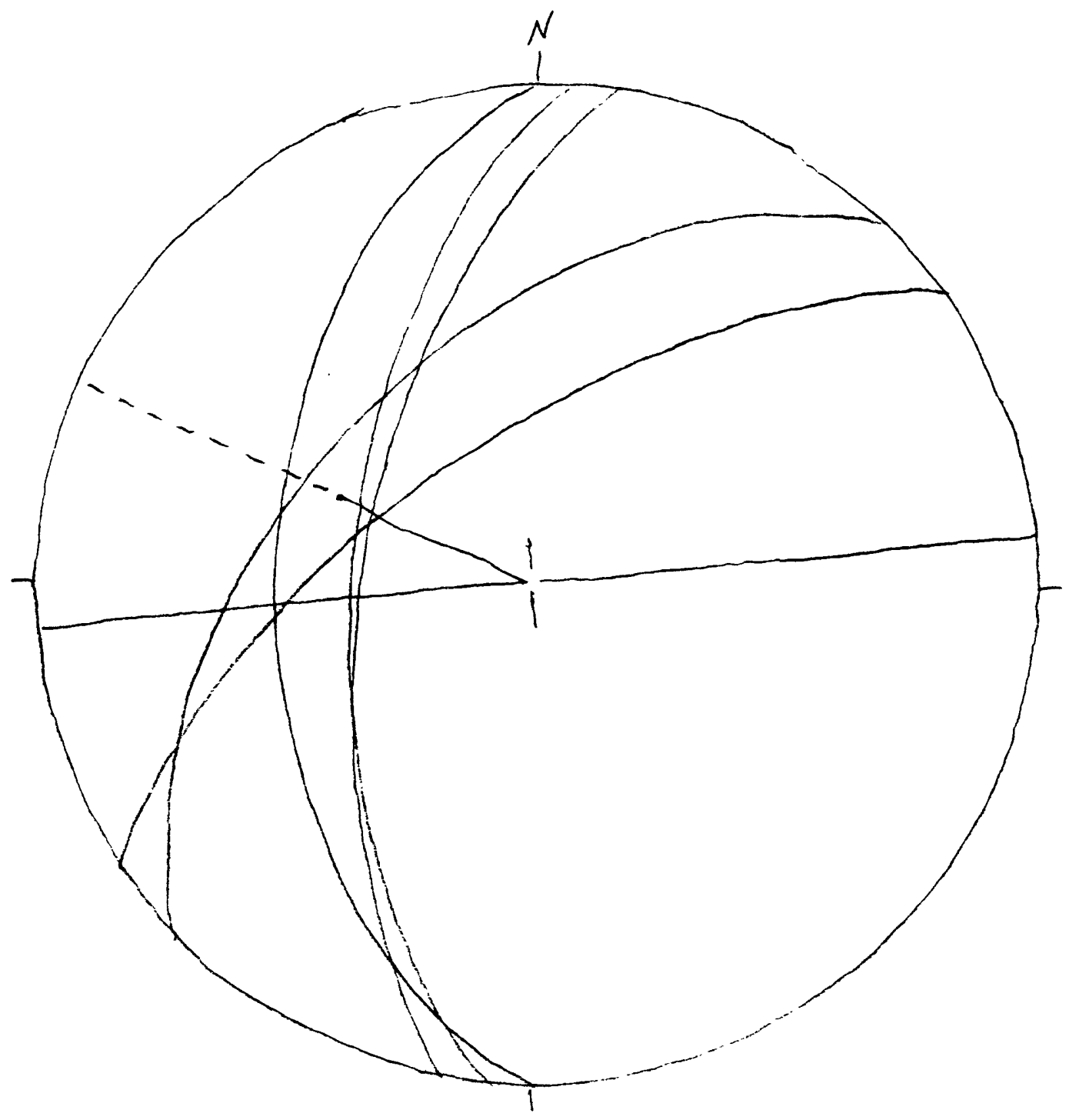

Eigure 86. Six cleavage planes from previous figures, Ross Gulch subarea, Coeur d'Alene district, Idaho. Estimated hinge 55 N65W. Schmidt net, lower hemisphere. 


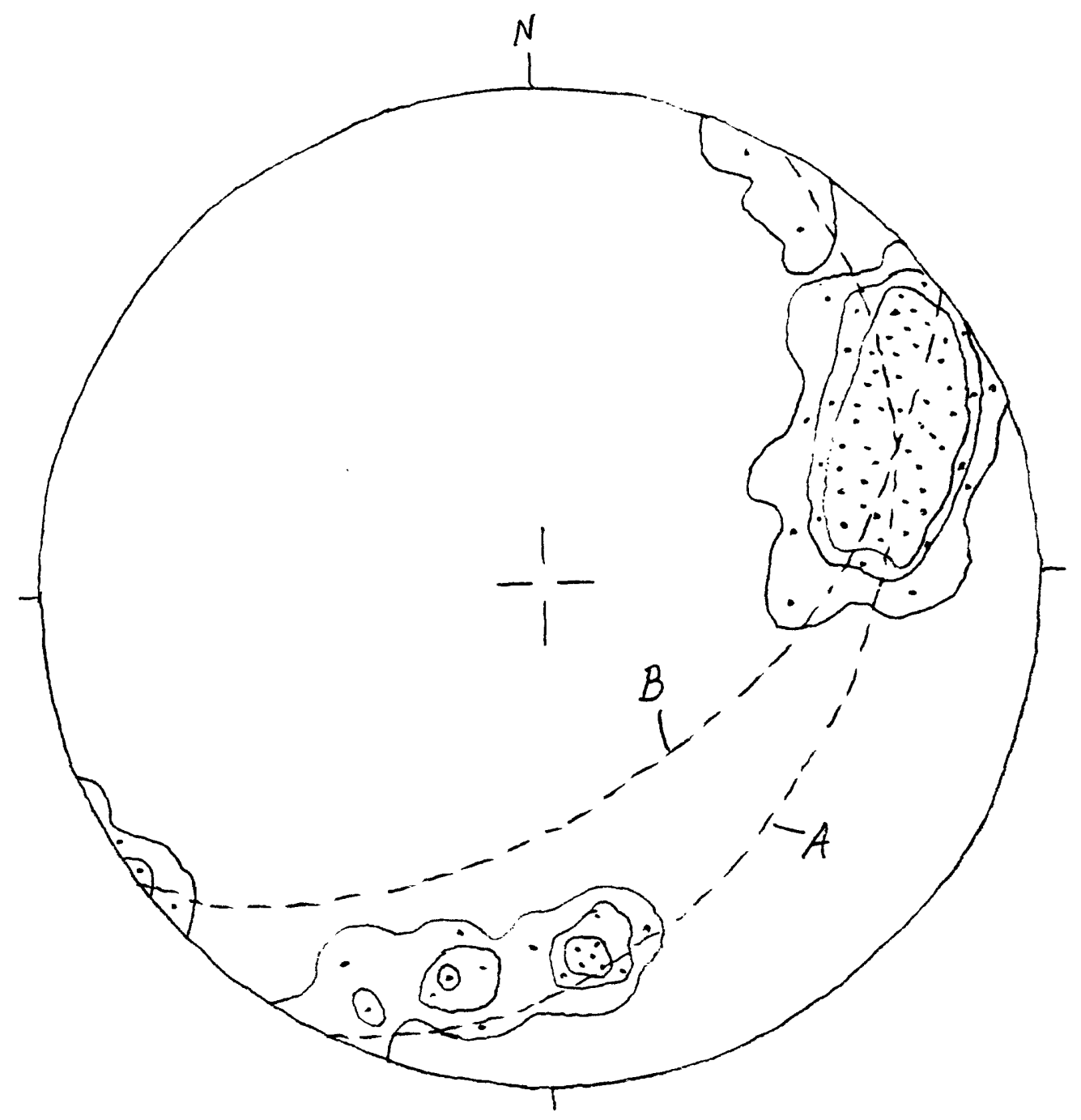

Eigure 87. PI diagram, bedding, Ross Gulch subarea, Coeur d' Alene district, Idaho. $N=100$. The data suggest two partial crossed girdles: A, N22E 36SE; and B, N54E 55SE. Girdle poles are: $A, 54 \mathrm{~N} 68 \mathrm{~W}$; and $B, 35 \mathrm{~N} 36 \mathrm{~W}$. The dominant bedding attitude is near N14W 62SW. Contours at $2,4,6 \%$ per $1 \%$ area. Schmidt net, lower hemisphere. 


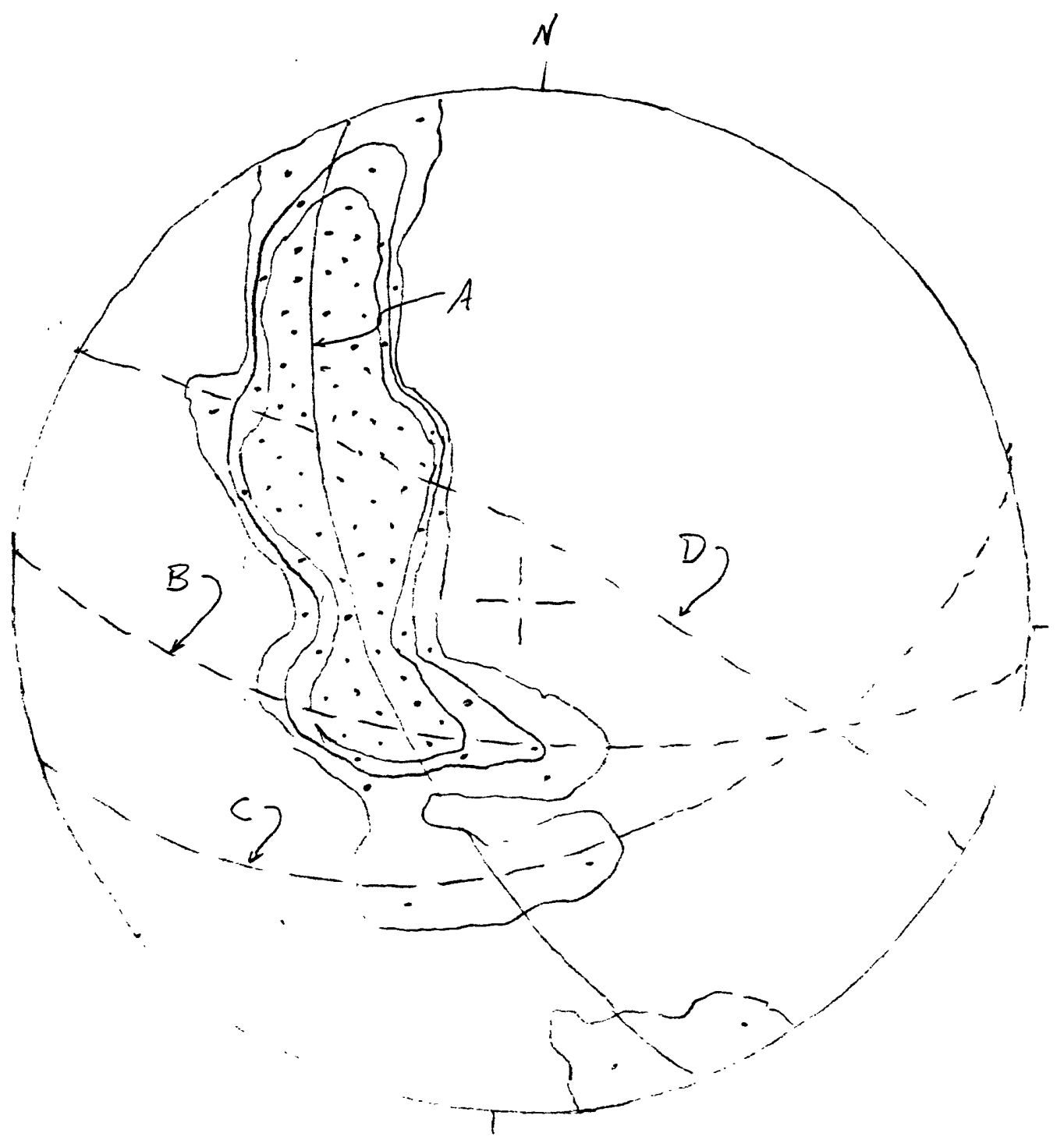

Figure 88. BETA diagram, bedding, Ross Gulch subarea, Coeur $d^{-}$ Alene district. Idaho. $N=4950$ points from intersection of 100 planes. The principal girdle, $A$, is oriented $N 25 \mathrm{~W}$ 65SW. Possible partial cross-girdles are: B, N86W 67SW; C, N7DE 48SE; and $D, N 64 \mathrm{~W} ; 80 \mathrm{NE}$. Contours at $1,2,3 \%$ per $1 \%$ area. Schmidt net, lower hemisphere. 


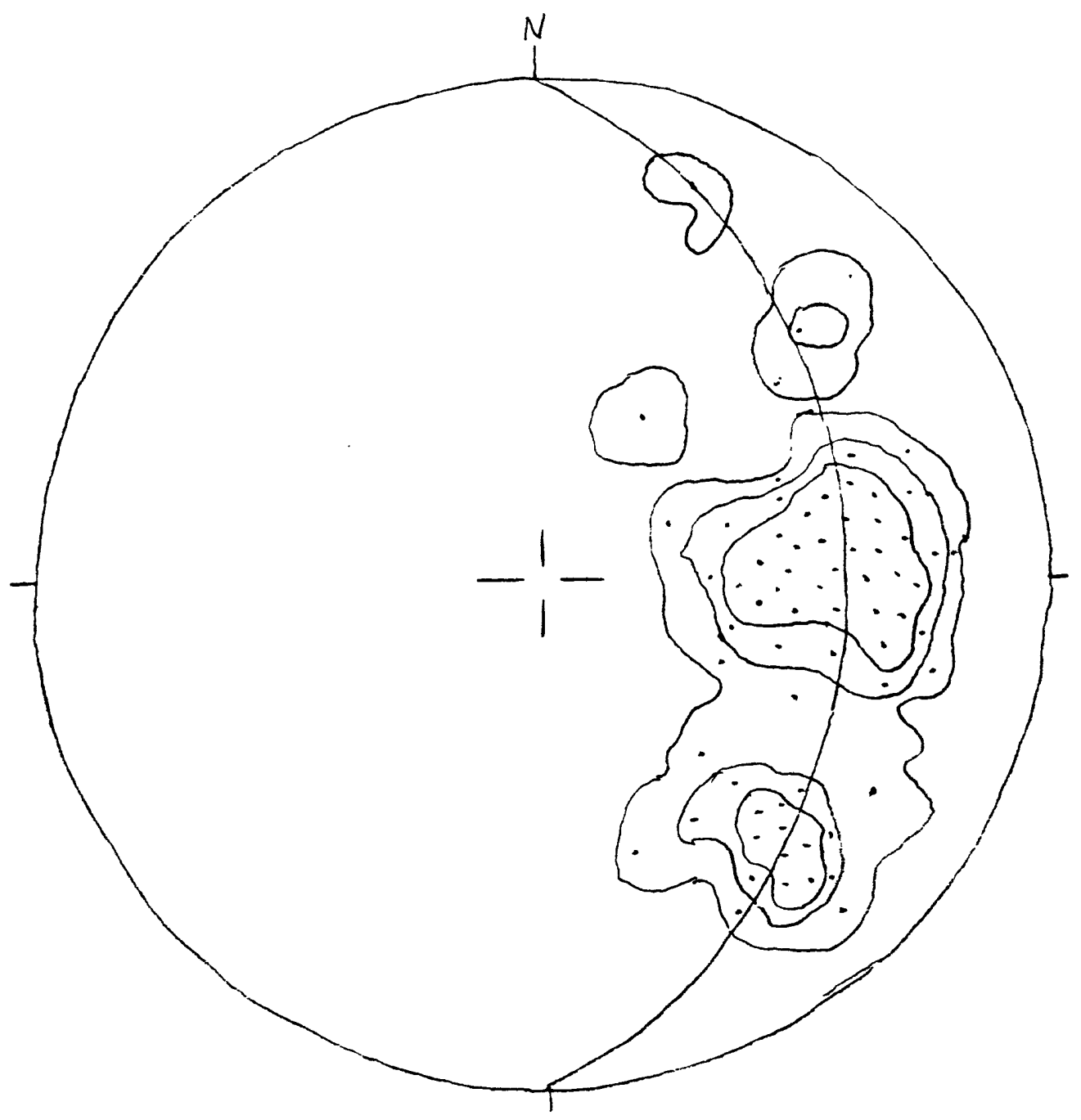

Eigure 89. PI diagram, cleavage, Ross Gulch subarea, Coeur $d^{*}$ Alene district, Idaho. $N=100$. Partial girdle NOOE 4OE; its pole is oriented $50 \mathrm{~N}$ NoW. Two clusters of poles, one at 40 N84E and the other at $30 \mathrm{~S} 41 \mathrm{E}$, represent two major, average cleavage trends. They are, respectively, N04W 50SW and N48E 60NW. Contours at $2,4,6 \%$ per $1 \%$ area. Schmidt net, lower hemisphere. 


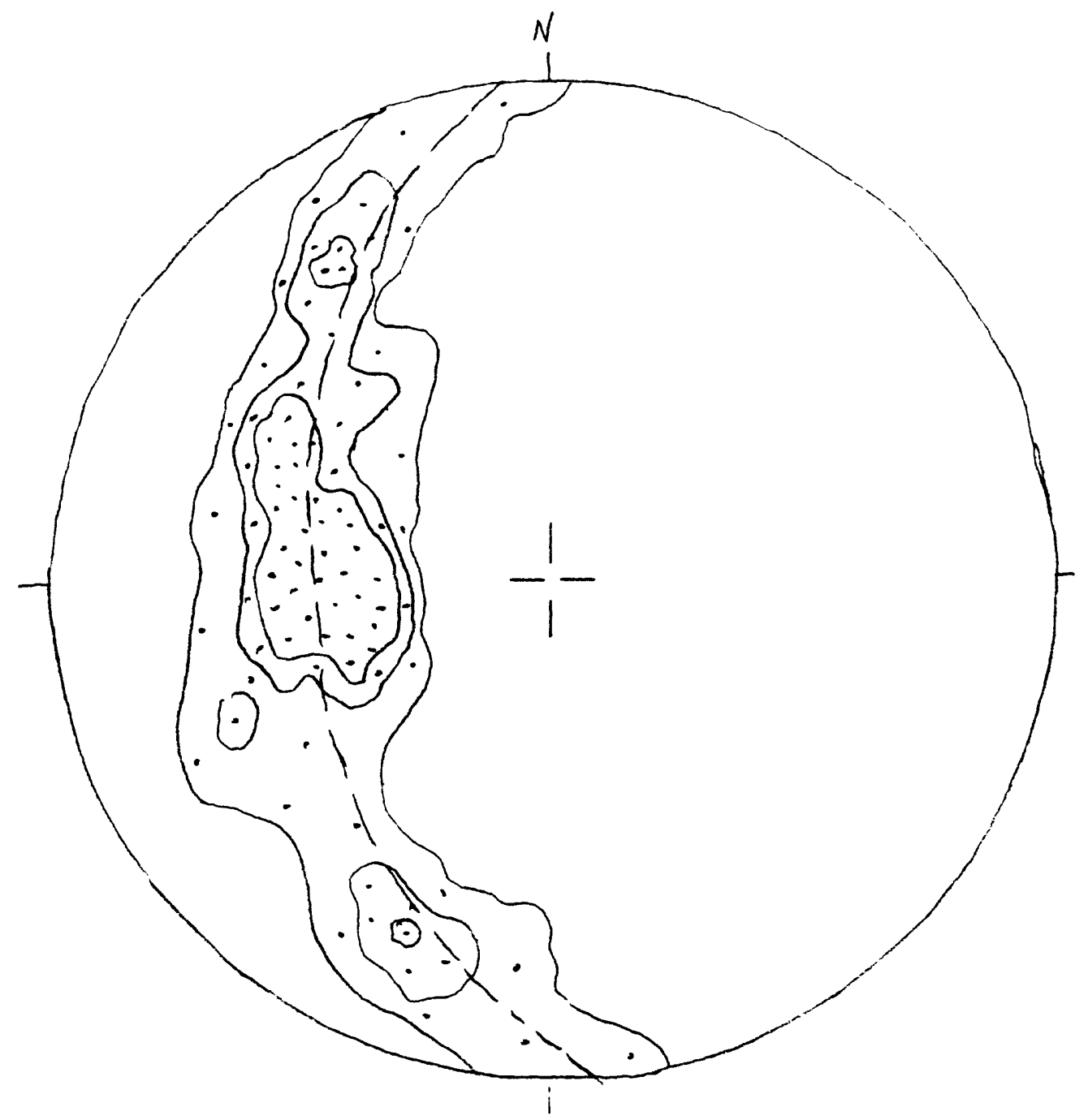

Eigure 90. BETA diagram, cleavage, Ross Gulch subarea, Coeur d' Alene district, Idaho. $N=4950$ points from intersections of 100 planes. Girdle oriented N05W 50SW. Major point concentration at $50 \mathrm{~N} 88 \mathrm{~W}$; subordinate point concentrations at $30 \mathrm{~N} 35 \mathrm{~W}$ and $30 \mathrm{~S} 23 \mathrm{~W}$. Contours at $1.5,3.0$, and $4.5 \%$ per $1 \%$ area. Schmidt net, lower hemisphere. 


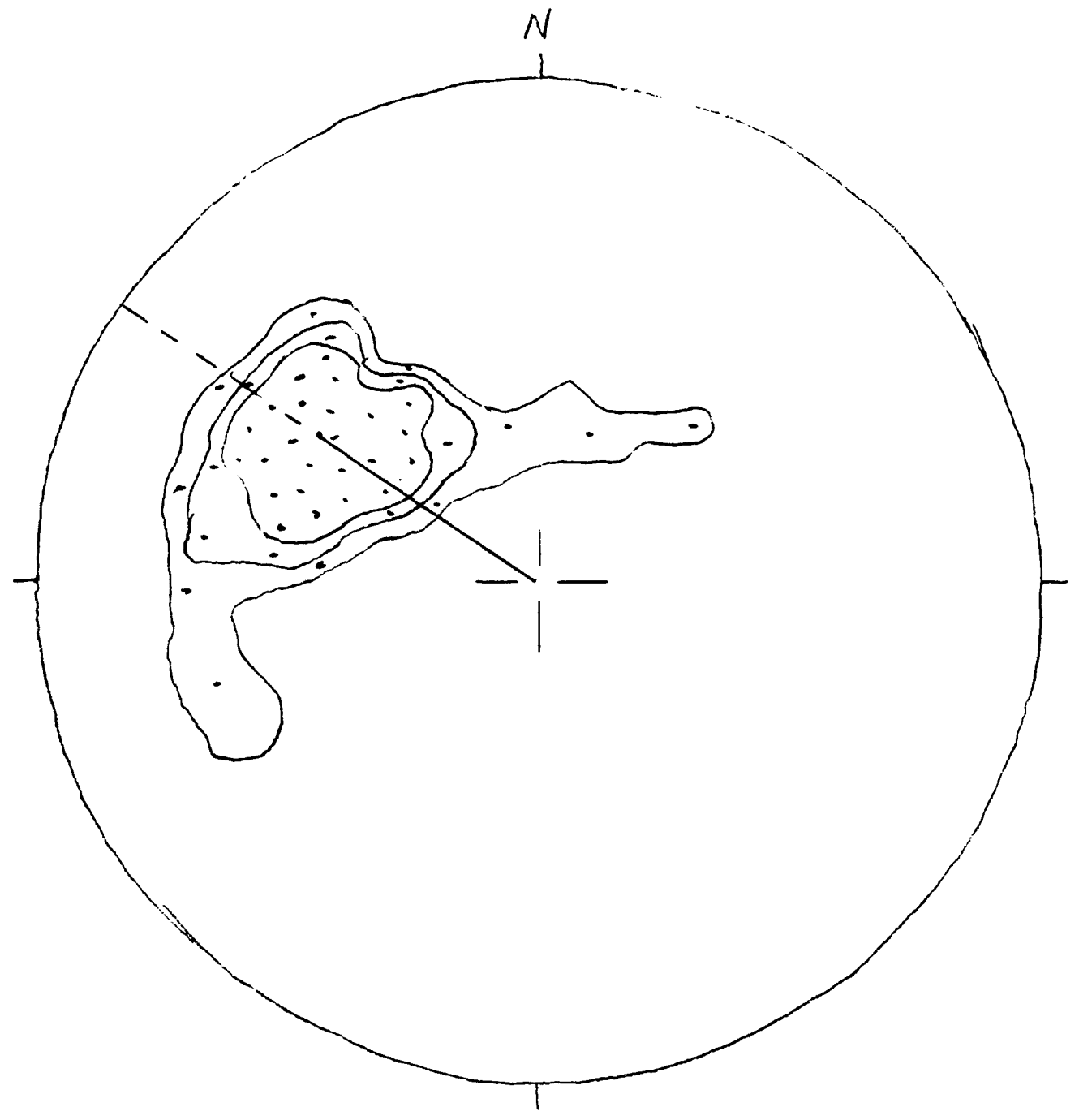

Eigure 91. L diagram, hinges, rods, and boudins, Ross Gulch subarea, Coeur $d^{-}$Alene district, Idaho. $\mathrm{N}=53$. Average linear element 46 N56W. Contours at $2,4,6 \%$ per $1 \%$ area. Schmidt net, lower hemisphere. 
Another set of linear elements is that expressed by the bedding-cleavage intersections (Eig. 92); a strong maximum is oriented $42 \mathrm{~N} 44 \mathrm{~W}$, similar to hinges, rods, boudins, and the fold axis of bedding, and close to the fold(?) axis of the cleavage.

The data set, allows measurement of 8.9 bedding-cleavage angles. The range is from $03^{\circ}$ to $88^{\circ}$, with a wide scatter through the range and no dominant angle or angles. Similarly, the data set contains measurements from 22 outcrops in which bedding, cleavage, and rods/hinges were all available. Thus, rod/hinge measures can be compared to cleavage-bedding intersection lineation from those 22 places. The angles between these elements range widely--from $03^{\circ}$ to $86^{\circ}$, and in a seemingly random way.

Data from Eigures.87-92 are compiled in Figure 93. These data are analyzed in some detail to provide a subarea comparison to the larger area of intensely deformed Prichard rocks. The various girdles and point concentrations are all rather diffuse, and great accuracy in trend determination is therefore not, possible. However, many similarities exist. An oriented specimen from the Ross Gulch subarea of the TEZ shows complex fabric. The most significant element is a crude microrodding representing a stretch lineation plunging generally toward the WNW, broadly parallel to the trend of the high-strain zone and to the plunge of the structural elements within it.

Cleavage Detail in the Moon Creek and Terror Gulch Subareas.

Erom its internal structural geometry in the Kellogg area, described above, the high-strain zone could trend about N55W. If that is so (Hypothesis A), and given its width of about three miles measured north of Kellogg, it would be cut off at its northern margin by the Osburn fault at a point nearly due north of the town of Wallace (Eig. 1). Alternately, from sketchy data on its southern margin (located from those data more or less along the axis of the South Fork of the Coeur d'Alene River at, the town of Rellogg), it may trend from N70W to N90W (Hypothesis B). In the latter case, its internal fabric will lie at an angle to its walls.

Hypothesis A would require that Prichard rocks southwest of the Carpenter Gulch fault (Fig. 1) and in the valleys of upper Moon Creek and upper Terror Gulch (detailed location for the Moon Creek subarea) lie in wall rocks to the northeast of the TEZ. Eurther, Prichard rocks in the valleys of lower Terror Gulch and lower Twomile Creek (Eig. 1) (detailed location for the Terror Gulch subarea) would lie within the zone. Hypothesis B would require the reverse: to wit: rocks of the Moon Creek subarea would lie in the zone, and rocks of the Terror Gulch subarea would lie in wall rocks to the south of the zone.

Work described above has established some structural geometric characteristics of the high-strain zone and of wall rocks to its south and north. Structural geometry of available bedding and cleavage orientation data from the Moon Creek and Terror Gulch sixbareas may then be compared to data from the above work in an attempt to learn the trend of the high-strain zone through the central Coeur $d$ 'Alene district. Of course, we 


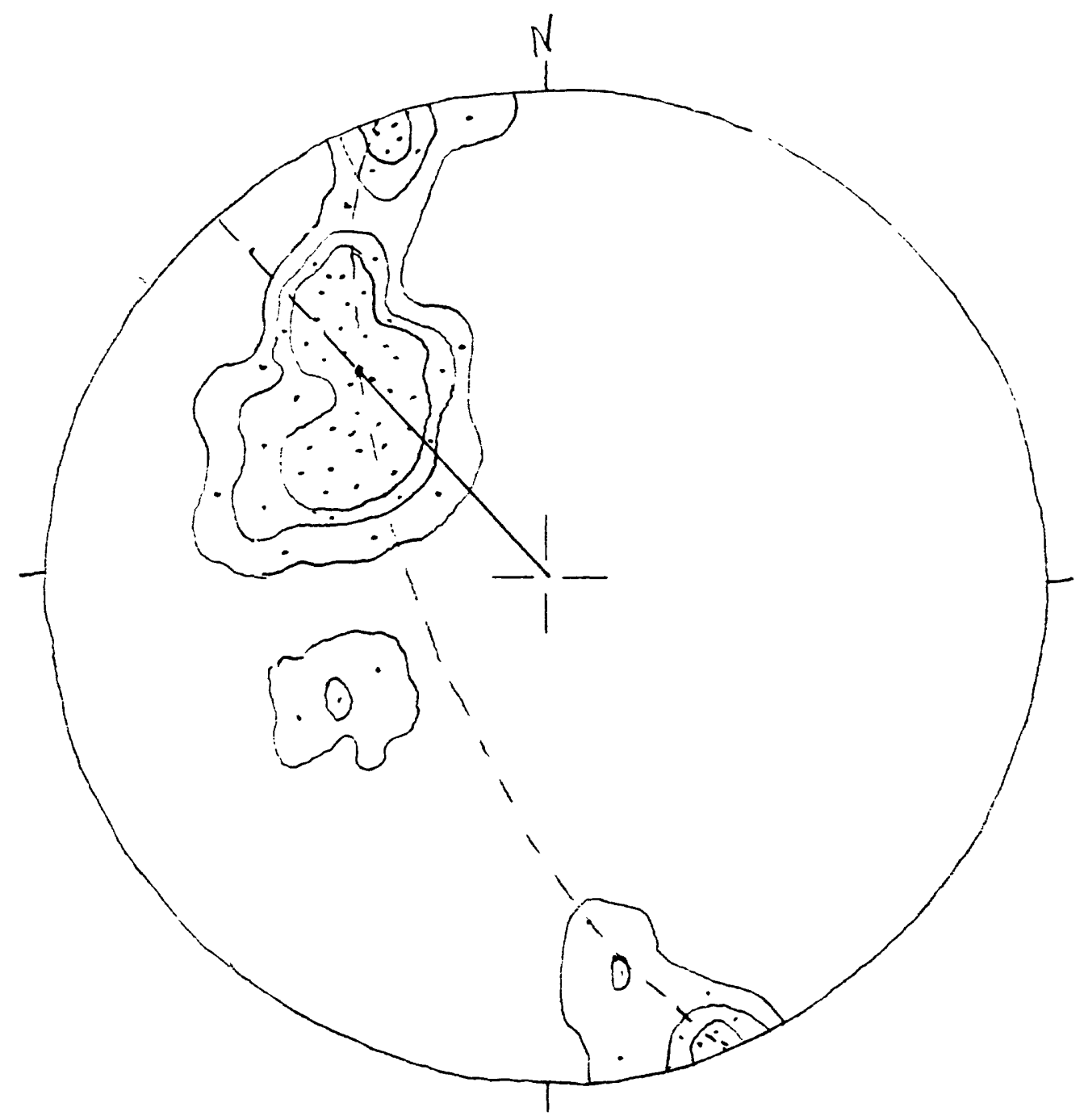

Eigure 92. L diagram, bedding-cleavage intersections, Ross Gulch subarea, Coeur d' Alene district, Idaho. $\mathrm{N}=89$. Partial girdle N22W 68SW. Major point concentration 42 N44W. Contours at 2 , 4, $6 \%$ per $1 \%$ area. Schmidt net, lower hemisphere. 


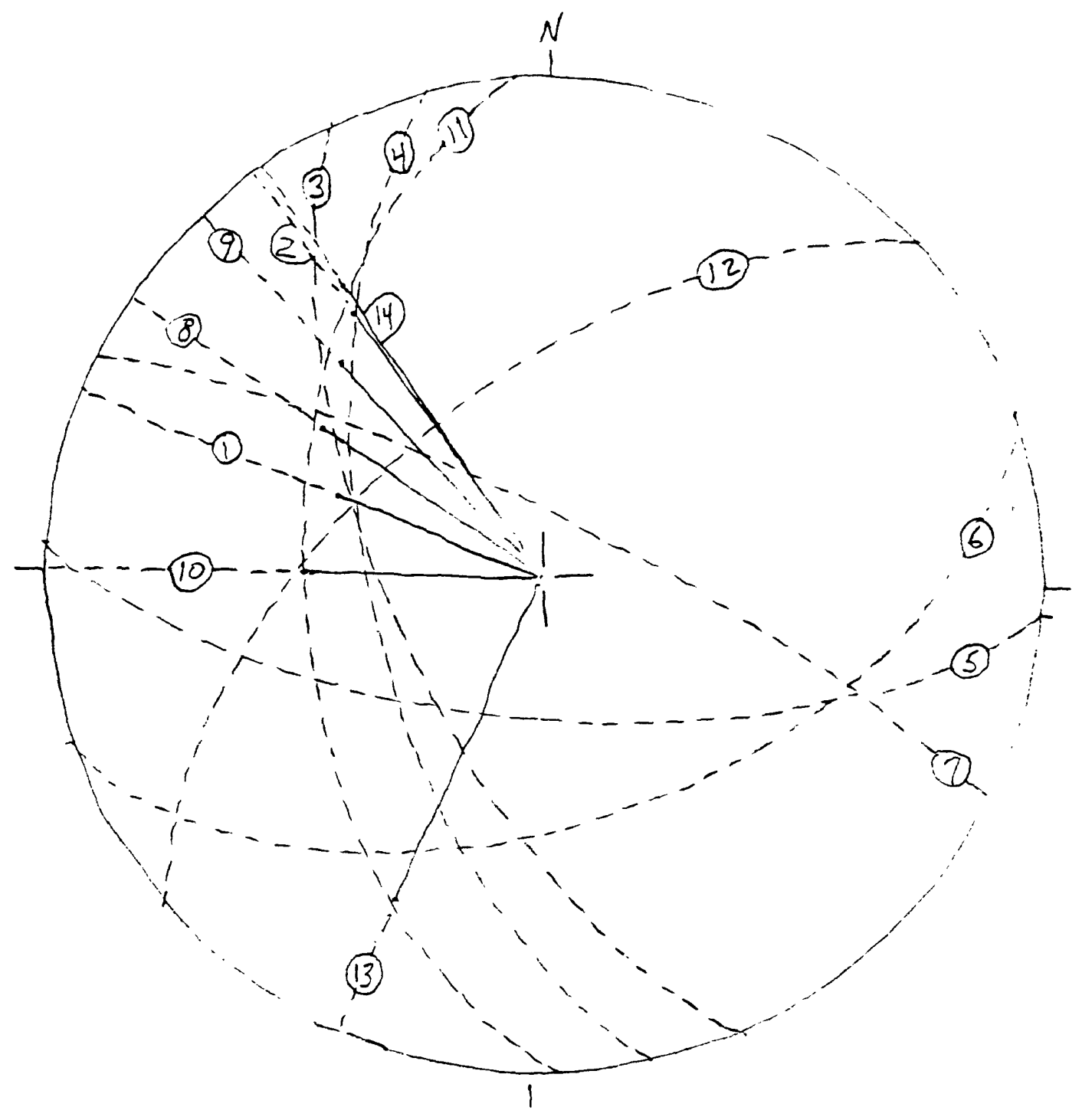

Figure 93. Composite diagram, Ross Gulch subarea, Coeur d' Alene district, Idaho. (1) Pole A to bedding PI girdle, $54 \mathrm{~N} 68 \mathrm{~W}$. Pole $B$ to bedding PI girdle, $35 \mathrm{~N} 36 \mathrm{~W}$. (3) BETA girdle, bedding, $\mathrm{N} 25 \mathrm{~W}$ 65SW. (4) Average bedding N14W 62SW. (5) BETA bedding cross-girdle N86W 67SW. (6) BETA bedding cross-girdle N70E 48SE. (7) BETA bedding cross-girdle N64W 80NE. (8) Hinges, rods, and boudine average trend $46 \mathrm{~N} 56 \mathrm{~W}$. (9) Average bedding-cleavage intersections $42 \mathrm{~N} 44 \mathrm{~W}$. (10). Pole to PI girdle on cleavage parallel to the BETA cleavage maximum $50 \mathrm{~N} 90 \mathrm{~W}$. (11) PI cleavage girdle and BETA cleavage maximum N04W 50SW. (12) PI cleavage, secondary maximum N48E 60NW. (13) BETA cleavage maximum $30 \mathrm{~S} 23 \mathrm{~W}$. (14) BETA cleavage maximum $30 \mathrm{~N} 35 \mathrm{~W}$. Schmidt net, lower hemisphere. 
already mentioned above that the zone should pass through the area of the Star-Morning mine, allowing a trend near N9OW, but, checking in intervening areas is still necessary. Strikes and dips were compiled from Hobbs and others, 1965, Plate 3 . First, the Moon Creek subarea will be compared to the high-strain zone near Kellogg.

A PI diagram (not shown) on bedding in the Moon Creek subarea shows a diffuee girdle near $N 80 E$ 6OSE for an average fold axis near $30 \mathrm{~N} 10 \mathrm{~W}$. This may be compared to Figures 24 and 87 . A BETA diagram (not shown) on bedding in the Moon Creek subarea shows a strong, rather diffuse girdle oriented N90W $32 \mathrm{~N}$, and a strong maximum in the girdle near $30 \mathrm{~N} 10 \mathrm{~W}$, consistent with the fold axis from the bedding PI diagram. This may be compared to Figures 25 and 88 . These comparisons show fold axes in the NNW trend like those in the TEZ.

A PI diagram (not shown) on cleavage in the Moon Creek subarea shows a partial girdle oriented N55E 51SE and an axis (pole) at $29 \mathrm{~N} 35 \mathrm{~W}$. This may be compared to Figures 26 and 89. Cleavage data for the Moon Creek subarea show a partial girdle near N12W 61SW, with its pole at 29 N78E. This partial girdle shows a strong point concentration at 40 N40W. This material may be compared to that in Figures 27 and 90 . The comparisons show cleavage orientation similarities between the Moon Creek area and the TEZ. This completes the comparison of the Moon Creek subarea with the Kellogg area; it is next compared to wall-rock areas.

The wall rocks north of the high-strain zone are represented by data from Willoughby (1986, Plate $I$, north half) and from Hayden (1992, Plate 2, North Half). From Willoughby, only bedding data are available. The bedding PI, described earlier, shows a partial girdle at N87E, 73SE, and an axis at 17 N03W. This may be compared to N80E 60SE and 30 N1OW from the Moon Creek subarea. The bedding BETA, also described earlier, shows a strong girdle at $\mathrm{N} 9 \mathrm{OW} 17 \mathrm{~N}$, compared to $\mathrm{N} 90 \mathrm{~W} 32 \mathrm{~N}$ from the Moon Creek subarea. Note that the $\mathrm{NW}$ trend of the Moon Creek anticline (Eig. 1), from Hobbs and others, 1365, probably changes to N-S north of the TEZ, based on these data.

The next part of the test compares subarea fabric data of Terror Gulch to those of the high-strain zone and its wall rocks. Only bedding observations are available from Hobbs and others, 1965, Plate 3 . The seven mapped cleavages in the subarea are too few for statistical analysis.

A PI diagram on bedding in the Terror Gulch subarea shows a partial girdle oriented N55E $75 \mathrm{NW}$, for a hinge at 15 S.35E. Comparisons may be made with Figures 24 and 87 for the highstrain-zone bedding and Figure 16 for wall-rock bedding. The Terror Gulch subarea PI most closely resembles that of Figure 16.

A BETA diagram on bedding in the Terror Gulch subarea shows a girdle at $\mathrm{N} 20 \mathrm{~W} 50 \mathrm{NE}$. This girdle may reflect the northeast, limb of the Moon Creek anticline. Comparisons may be made with Figures 25 and 88 for the high-strain zone bedding and with Figure 16 for wall-rock bedding. It is markedly different from both of those; it is also different from the wall-rock BETA shown in Figure 17.

A one-day mapping project, in the Terror Gulch subarea was done by the 1991 structural geology class of the University of 
Idaho, as a part of their term report project. Orientation data were composited for statistical analysis (234 strikes and dipe on bedding and 77 on cleavage). Bedding is dominantly homoclinal; a partial PI girdle is oriented N5OE 9OSE, and its pole is at 00 N40W. Minor fold hinge trends are scattered, but the dominant trend parallels the PI pole. Bedding BETA shows a girdle at N40W $77 \mathrm{NE}$ for the dominant homocline orientation; the homocline is $a$ part of a set of tight conical folds developed about steeply dipping axial planes. Cleavage dips dominantly to the southwest; the BETA girdle is oriented N44W 54SW. About ten percent of the cleavage planes are oriented N43W 60NE (average), possibly conjugate. Cleavage cuts obliquely across minor folde in the bedding. Small offsets on some cleavage planes show south side up. Cleavage features resemble those of the wall rocks south of the high-strain zone. 